VILNIAUS GEDIMINO TECHNIKOS UNIVERSITETAS

Lijana MASKELIŪNAITÉ

\title{
TARPTAUTINIO KELEIVIŲ VEŽIMO GELEŽINKELIAIS PROCESO KOKYBĖS TYRIMO DAUGIATIKSLIS MODELIS
}

DAKTARO DISERTACIJA

TECHNOLOGIJOS MOKSLAI,

TRANSPORTO INŽINERIJA (03T)

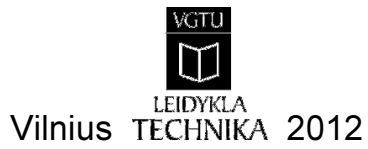


Disertacija rengta 2008-2012 metais Vilniaus Gedimino technikos universitete.

\section{Mokslinis vadovas}

prof. habil. dr. Henrikas SIVILEVIČIUS (Vilniaus Gedimino technikos universitetas, technologijos mokslai, transporto inžinerija - 03T).

VGTU leidyklos TECHNIKA 2070-M mokslo literatūros knyga http://leidykla.vgtu.lt

ISBN 978-609-457-013-1

(C) VGTU leidykla TECHNIKA, 2012

(C) Lijana Maskeliūnaitè, 2012

lijana.maskeliunaite@vgtu.lt 
VILNIUS GEDIMINAS TECHNICAL UNIVERSITY

Lijana MASKELIŪNAITÉ

THE MODEL FOR MULTICRITERIA

EVALUATION OF THE QUALITY OF PASSENGER TRANSPORTATION BY INTERNATIONAL TRAINS

DOCTORAL DISSERTATION

TECHNOLOGICAL SCIENCES,

TRANSPORT ENGINEERING (03T)

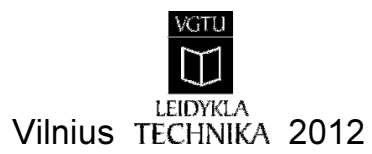


Doctoral dissertation was prepared at Vilnius Gediminas Technical University in 2008-2012.

\section{Scientific Supervisor}

Prof Dr Habil Henrikas SIVILEVIČIUS (Vilnius Gediminas Technical University, Technological Sciences, Transport Engineering - 03T). 


\section{Reziumè}

Disertacijoje nagrinëjamos tarptautinio keleivių vežimo geležinkeliais (TKVG) problemos. Pagrindinis darbo objektas - tarptautinio keleivių vežimo geležinkeliais procesas (TKVGP). Eksperimentiniais metodais nustatytas kelionès traukiniu kokybės kriterijų reikšmingumas ir šių kriterijų grupių svarba (pirmumas). Autorès suformuluotas TKVG kompleksinis daugiakriteris vertinimo modelis leido nustatyti vieno traukinio, vykstančio tam tikru maršrutu, vienareikšmį kiekybinį rodiklị. Pagrindinis disertacijos tikslas - pateikti tarptautinio keleivių vežimo geležinkeliais (kelionès traukiniu) kokybès (TKVGK) vertinimo metodologiją.

Disertaciją sudaro i̇vadas, keturi skyriai, rezultatu apibendrinimas, naudotos literatūros ir autorès publikacijų disertacijos tema sąrašai bei 12 priedų.

Ivade trumpai aptarta tiriamoji problema, darbo aktualumas, pristatytas tyrimų objektas, suformuluotas darbo tikslas bei uždaviniai, aprašyta tyrimų metodika, mokslinis darbo naujumas, praktinè rezultatų reikšmè bei pateikti ginamieji teiginiai. Ivado pabaigoje pristatomos autorès paskelbtos publikacijos ir pranešimai konferencijose disertacijos tema.

Pirmajame skyriuje atlikta geležinkelio infrastruktūros, riedmenų ir TKVGP mokslinių darbų analizè. Taip pat atlikta Lietuvos Respublikos (Europos Sajungos) norminių dokumentu̧, reglamentuojančių keleivių vežimo geležinkeliais kokybę, analizè.

Antrasis skyrius skirtas $A B$,Lietuvos geležinkeliai“ (LG) veiklos ir keleivių vežimo rodiklių apžvalgai, kelionès tarptautinio susisiekimo traukiniu kokybės kriterijų formulavimui ir sisteminimui. Sukurtas TKVGK kompleksinis daugiakriteris vertinimo modelis, taikytinas tarptautinio susisiekimo vieno traukinio vežimo kokybei nustatyti.

Trečiasis skyrius skirtas TKVGK kriterijų ir jų grupių svarbos tyrimui. Skyriuje pateikta: apklausos anketų struktūra, anketos duomenų tvarkymo skaitinis pavyzdys, respondentų nuomonių suderinamumo skaitinis pavyzdys, nustatyta vieno eksperto nuomoné apie kriterijų svarbą bei grupès respondentų ar ekspertų nuomonių suderinamumas. Atlikta respondentų ir ekspertų nuomonių apie kriterijų ir jų grupių svarbą analizè.

Ketvirtajame skyriuje pateiktas TKVGK kompleksinio daugiakriterio (daugiatikslio) modelio praktinio pritaikymo vertinimas. Atliktas kriterijų kitimo itakos kompleksiniam kokybès rodikliui tyrimas.

Disertacijos tema publikuoti 9 moksliniai straipsniai ir pristatyti 5 pranešimai mokslinèse konferencijose. 


\section{Abstract}

The dissertation considers the problems, associated with passenger transportation by international trains (PTIT). The research object is the process of passenger transportation by international trains (PPTIT). By using the experimental methods, the significances (weights) and the order of preferences of the qualitative criteria, describing this process, are determined. The complex model, deve-loped by the author for multicriteria PTIT evaluation, allows for determining a single-valued quantitative criterion for evaluating a particular train travelling on a particular route. The main aim of the dissertation is to offer a methodology for evaluating the quality of passenger transportation by international trains (QPTIT).

The dissertation consists of the Introduction, four chapters, the description of the obtained results, the list of references as well as the author's publications on the topic of the thesis and 12 annexes.

The Introduction briefly describes the research problem and object, the topicality of the work, its aim and objectives, and the applied research methods, as well as the novelty and practical value of the results obtained and the defended statements. Finally, the Introduction presents the list of the author's publications and reports delivered at the conferences on the topic of the dissertation.

Chapter 1 presents the analysis of the Lithuanian and EU standards and regulations, defining the quality of passenger transportation by rail. It also describes the analysis of the railway infrastructure, trains and the quality of passenger transportation by international trains (QPTIT).

Chapter 2 surveys the criteria, describing the activities of the joint-stock company AB "Lietuvos geležinkeliai" (LG) and passenger transportation, which are required for identifying and classifying the criteria, describing the quality of travel by international trains. The model, developed for complex multicriteria QPTIT evaluation, which can be used for determining passenger transportation quality of one particular international train, is also described.

Chapter 3 focusses on the determination of the significance of QPTIT criteria and their groups. The structure of the survey questionnaire, the numerical examples of the questionnaire's data processing and the consistency of the respondents' judgements, as well as the opinion of one expert about the significance of the criteria and the consistency of the judgements of a group of respondents or experts, are described. The analysis of the opinions of the respondents and experts about the significance of the criteria and their groups is also presented.

Chapter 4 describes the assessment of practical application of the presented QPTIT complex multicriteria model. A research on the impact of the criterion value variation on the comprehensive quality index has been performed.

The author of the dissertation published 9 articles in the scientific journals and made 5 reports at the scientific conferences. 


\section{Žymenys}

\section{Simboliai}

$A G$ - restorano vagono patiekalų asortimento gausa (pasirinkimas);

$A I_{f}, A I_{\max }$ - avarinių išejimų buvimo $c$-ajame vagone faktiškoji ir maksimali vertè;

$A P B_{f}, A P B_{\max }-k$-ojo keleivio aptarnaujančio personalo bendravimo kultūros su keleiviais ir tarpusavyje vertinimo faktiškoji ir maksimali verté;

$A P I_{f}, A P I_{\max }-k$-ojo keleivio aptarnaujančio personalo išvaizdos (uniformos aprangos, avalynès, šukuosenos, vardinès kortelès) vertinimo faktiškoji ir maksimali verté;

$B_{M K_{1}}, B_{M K_{2}}, \ldots, B_{M K_{n}}-n$-asis maisto patiekalo ịvertinimo balas;

$B A_{f}, B A_{\max }$ - keleivio bagažo ir daiktų traukinyje apsaugos faktiškoji ir maksimali vertė; $B K_{f}, B K_{\min }, B K_{\max }-y$-osios kategorijos vagono faktinè, mažiausia ir didžiausia bilieto kaina;

$B P_{f}, B P_{\max }-$ kelionès bilieto pirkimo traukinyje galimybės (iš traukinio viršininko) faktiškoji ir maksimali verte;

$b$ - reiso (maršruto) tarpinių stočiu $B$ skaičius;

C.I. - (consistency index) matricos suderinamumo indeksas;

C.R. - (consistency ratio) suderinamumo santykis, rodantis matricos suderinamumo laipsni; 
$D_{f}, D_{\max }$ - irengto nuolat veikiančio dušo faktiškoji ir maksimali verte;

$D L_{f}, D L_{\max }$ - galimybės traukinyje pasinaudoti plaukų džiovintuvu, drabužių lygintuvu faktiškoji ir maksimali verte;

$D V_{f}, D V_{\max }$ - specialių kupe dviračiams vežti faktiškoji ir maksimali vertė;

$F$ - gaisro gesinimo priemonių rūšių vagone skaičius;

$F E_{f}, F E_{\max }$ - gesintuvų buvimo ir būklès $c$-ajame vagone faktiškoji ir maksimali vertè;

$G_{f}, G_{\max }-$ gultų konstrukcijos, specialiujų priemonių neigaliesiems $c$-ajame vagone faktiškoji ir maksimali verte;

$G G I_{f}, G G I_{\max }$ - GGI buvimo $c$-ajame vagone faktiškoji ir maksimali verte;

$G G P_{f}, G G P_{\max }$ - gaisro gesinimo priemonių rūšių faktiškoji ir maksimali verté;

$G M P_{f}, G M P_{\max }-$ greitosios medicinos pagalbos iškvietimo į traukini galimybès faktiškoji ir maksimali verte;

$H$ - traukinio stabdymo įrenginių rūšių vagone skaičius;

$I_{f}, I_{\max }-c$-ojo vagono interjero faktiškoji ir maksimali verte;

$I I A_{f}, I I A_{\max }-c$-ojo vagono aprūpinimo pramonine IIA faktiškoji ir maksimali verte;

$I P_{f}, I P_{\max }$ - prieigos prie interneto faktiškoji ir maksimali verte;

$I V_{f}, I V_{\max }$ - vizos ịsigijimo pasienio punkte galimybès faktiškoji ir maksimali verte;

$J$ - visų restorano vagone parduotų patiekalų dažnis (parduotos porcijos);

$J_{d}-d$-ojo patiekalo dažnis (parduotos porcijos);

$K$ - kelionès traukiniu kokybès kompleksinio vertinimo rodiklis;

$K K I_{f}, K K I_{\max }$ - faktiškas ir ribinis kelmačiu išmatuoto vieno kilometro ilgio ruožo KKI;

$L$ - geležinkelio ruožo ilgis;

$L \check{Z}_{f}, L \check{Z}_{\max }$ - laikraščių ir žurnalų kainos faktiškoji ir maksimali vertė;

$l_{l}-$ atskiru tarpstočių ilgiai;

$M$ - kriteriju grupių skaičius;

$M D_{f}, M D_{\max }$ - maisto davinio pateikimo už į bilietą isskaičiuotą kainą $c$ vagone faktiškoji ir maksimali verte;

$M I D_{f}, M I D_{\max }-$ užsienio medicininių išlaidų draudimo ịsigijimo traukinyje galimybės faktiškoji ir maksimali verte;

$M I D K_{f}, M I D K_{\min } M I D K_{\max }$ - užsienio medicininių išlaidų draudimo kainos faktiškoji, minimali ir maksimali verté;

$M K_{f}, M K_{\max }-$ galimybès traukinyje atsiskaityti mokejjimo kortele faktiškoji ir maksimali verte;

$M P_{f}, M P_{\max }-$ keleivinio vagono su dvivietėmis kupe maisto davinio pateikimo faktiškoji ir maksimali verte;

$M P K_{f}, M P K_{\max }-k$-ojo keleivio muitinès ir pasienio pareigūnų kompetencijos, objektyvumo ir bendravimo su keleiviais kultūros faktiškas ir didžiausias galimas įvertinimas balais; 
$M U_{f}, M U_{\max }$ - maisto ir gérimų užsakymo iš restorano vagono ir atnešimo į kupe galimybès (per vagono palydova) faktiškoji ir maksimali verté;

$m$ - lyginamų rodiklių (kriteriju) skaičius kriterijų grupejje;

$N$ - respondentų (ekspertu) kategorijų skaičius;

$N_{A+C}$ - pradinèje (išvykimo) stotyje ịlaipintų keleivių ir važiuojančių iki galinès (atvykimo) stoties skaičius;

$N_{k m}$ - viso kelio ilgis;

$N_{\text {reiso }}$ - visų (ilipusių pradinèje ir tarpinėse stotyse ir išlipusių tarpinėse bei galinèje stotyje) reise (maršrute) važiavusių keleivių skaičius;

$n$ - respondentų (ekspertu) skaičius;

$n_{A}$ - ekspertų (AB „Lietuvos geležinkeliai“ administracijos darbuotojų) skaičius;

$n_{D}$ - restorano vagone parduodamų patiekalų skaičius;

$n_{K}$ - respondentų (keleiviu) skaičius;

$n_{P}-$ ekspertu (traukini aptarnaujančio personalo) skaičius;

$n_{T}$ - temperatūros matavimų skaičius;

$n_{W}$ - kelionei reikalingų vizų skaičius;

$O S P_{f}, O S P_{\text {max }}-$ OSP-1 buvimo ir būklès $c$-ajame vagone faktiškoji ir maksimali vertè;

$P_{f}, P_{\max }$ - patalynès keleiviui pateikimo, paklojimo ir jos būklès $c$-ajame vagone faktiškoji ir maksimali verte;

$P I_{f}, P I_{\max }$ - palydovo skubaus iškvietimo į kupè $c$-ajame vagone galimybės faktiškoji ir maksimali verte;

$P K$ - restorano vagone parduodamų patiekalų kaina;

$P K_{d}-d$-ojo restorano vagone parduodamo patiekalo kaina;

$P K_{\min }$ - mažiausia restorano vagone parduodamų patiekalų kaina;

$P K_{\text {vid }}$ - vidutinè restorano vagone parduodamų patiekalų kaina;

$P K P$ - restorano vagono patiekalų keitimo periodiškumas;

$P K P_{f}, P K P_{\max }$ - faktiškoji ir maksimali restorano vagono patiekalų periodiškumo vertė;

$P M P_{f}, P M P_{\max }-$ pirmosios medicinos pagalbos priemonių buvimo traukinyje faktiškoji ir maksimali verte;

$P P I_{f}, P P I_{\max }$ - policijos pareigūnų iškvietimo galimybės faktiškoji ir maksimali vertė;

$P S_{f}, P S_{\max }$ - prekybos suvenyrais traukinyje faktiškoji ir maksimali vertė;

$\bar{Q}_{g j}-g$ kriteriju grupès $j$ kriterijaus vidutinis svorio koeficientas;

$Q_{g j z}-g$ kriterijų grupei $z$ kategorijos respondentų (ekspertu) $j$ kriterijui suteiktas svorio koeficientas;

$R_{j}$ - kiekvieno rodiklio (kriterijaus) rangų suma;

$\bar{R}$ - vidutinis kiekvieno kriterijaus rangas; 
$\left|R_{1-2}\right|_{j}$ - tiriamos kriterijų grupės $j$ kriterijui respondentų ir ekspertų arba ekspertu ir ekspertų suteiktų rangų skirtumo modulis (absoliučioji reikšmè);

$R_{i j}-i$-ojo respondento (eksperto) $j$-ajam kriterijui suteiktas rangas;

R.I. - (random index) atsitiktinio indekso vidurkis;

$R M_{f}, R M_{\max }$ - radijo mazgo ir jo centralizuoto jjungimo ir išjungimo $c$-ajame vagone faktiškoji ir maksimali verte;

$R M K$ - restorano vagono maisto (patiekalu) kokybė;

$R S_{f}, R S_{\text {max }}$ - rankinio stabdžio veikimo ir būklès $c$-ajame vagone faktiškoji ir maksimali verte;

$R V_{f}, R V_{\max }$ - rūkyti skirtų vietų traukinyje faktiškoji ir maksimali verte;

$r$ - tarpstočių skaičius;

$S$ - vidutinio rango kvadratu suma;

$S K_{f}, S K_{\max }$ - stabdų būklès $c$-ajame vagone faktiškoji ir maksimali vertė;

$S P_{f}, S P_{\max }$ - populiariosios spaudos platinimo traukinyje faktiškoji ir maksimali verte;

$T I_{f}, T I_{\max }$ - taksi paslaugos traukinyje užsakymo faktiškoji ir maksimali vertė;

$T L_{f}, T L_{l}$ - triukšmo lygio $c$-ajame vagone faktiškoji ir didžiausia leidžiamoji vertė;

$T M K_{f}, T M K_{\max }-k$-ojo keleivio traukinyje transliuojamų muzikos kūrinių, informacijos atitikties keleivių norams vertinimo faktiškoji ir maksimali verte;

$T S P_{f}, T S P_{\text {max }}$ - traukinio stabdymo priemonių rūšių faktiškoji ir maksimali vertè;

$T_{L}$ - mažiausia leidžiamoji oro temperatūra vagone;

$T_{U}$ - didžiausia leidžiamoji oro temperatūra vagone;

$T_{f}$ - išmatuota AKAK temperatūra;

$T_{\text {apl.oro }}$ - aplinkos oro temperatūra matavimo vietoje (stotyje);

$T_{r i b}$ - ribinè AKAK temperatūra;

$\bar{T}_{f}-c$-ojo vagono vidutinè vidaus oro temperatūra, išmatuota atskirose jo vietose $t$ kartu visame kelionès maršrute;

$T_{f t}-t$-ojo matavimo temperatūra;

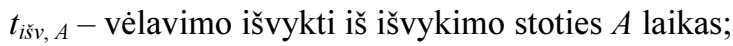

$t_{a v v, C}$ - vèlavimo atvykti į atvykimo (galinę) stotị $C$ laikas;

$t_{a t v, B}-$ vèlavimo atvykti i tarpinę $B$ stotị laikas;

$t_{i \check{s} v, B}$ - vèlavimo išvykti iš tarpinès $B$ stoties laikas;

$t_{a t v, l}=t_{i \check{s}, l}-$ vèlavimo atvykti ar išvykti i išvykimo, atvykimo ar tarpinę stotị tolerancija;

$U K_{f}, U K_{\max }-p$-ojo traukinį aptarnaujančio darbuotojo užsienio kalbos mokèjimo faktiškoji ir maksimali verte;

$U P S_{f}, U P S_{\max }$ - UPS buvimo ir būklès $c$-ajame vagone faktiškoji ir maksimali vertė;

$V$ - sąstato vagonų skaičius; 
$V_{K}-2$-os klasės miegamujų 4-ių vietų kupè vagonų skaičius;

$V_{M}$-1-os klasės minkštujų 2-jų vietų kupè vagonų skaičius;

$V_{P}-2$-os klasės paprastujų miegamujų vagonų skaičius;

$V_{Y}-y$-osios kategorijos sastato vagonų skaičius;

$V K_{f}, V K_{\min }, V K_{\max }$ - vizų kainos faktiškoji, minimali ir maksimali verte;

$V K_{f B}, V K_{\min B}, V K_{\max B}-$ Baltarusijos tranzitinès vizos faktiškoji, minimali ir maksimali verte;

$V K_{f R}, V K_{\min R}, V K_{\max R}-$ Rusijos vizos kainos faktiškoji, minimali ir maksimali verte;

$V K A_{f}, V K A_{\max }-c$-ojo vagono vèdinimo, oro kondicionavimo, apšvietimo ịrangos veikimo faktiškoji ir maksimali verte;

$V K B_{f}, V K B_{\max }-c$-ojo vagono išorinès būklès (švaros, pažaidų) faktiškoji ir maksimali verte;

$V R_{f}, V R_{\max }-$ restorano vagono faktiškoji ir maksimali verte;

$V R R_{f}, V R R_{\max }$ - vietų restorano vagone rezervavimo galimybès faktiškoji ir maksimali verte;

$V T T_{f}, V T T_{\max }$ - turèklų, laiptelių, perèjimo aikštelių, durų ir spynų tvarkingumo $c$-ajame vagone faktiškoji ir maksimali verte;

$v_{\max , l}$ - didžiausias leidžiamasis traukinio važiavimo $l$-uoju tarpstočiu greitis;

$\Delta v_{f}$ - faktiško ir didžiausio leidžiamojo traukinio važiavimo $l$-uoju tarpstočiu greičio pokytis;

$W$ - Kendall'o konkordancijos koeficientas;

$W_{\min }-$ mažiausia konkordancijos koeficiento reikšmé;

$W C_{f}, W C_{\max }-c$-ojo vagono sanitarinių mazgų faktiškoji ir maksimali verte;

$x_{A 1}, x_{A 2}, \ldots, x_{A m}$-A grupès $j$-ojo kriterijaus kintamasis dydis, iš kurio vertès apskaičiuojamas kriterijaus faktiškas lygmuo;

$x_{B 1}, x_{B 2}, \ldots, x_{B m}-\mathrm{B}$ grupès $j$ kriterijaus kintamasis dydis, iš kurio vertès apskaičiuojamas kriterijaus faktiškas lygmuo;

$x_{C 1}, x_{C 2}, \ldots, x_{C m}-\mathrm{C}$ grupės $j$ kriterijaus kintamasis dydis, iš kurio vertès apskaičiuojamas kriterijaus faktiškas lygmuo;

$x_{D 1}, x_{D 2}, \ldots, x_{D m}-\mathrm{D}$ grupès $j$ kriterijaus kintamasis dydis, iš kurio vertès apskaičiuojamas kriterijaus faktiškas lygmuo;

$Z_{j}-j$ kriterijaus svarbumo rodiklis;

$Z_{g z}-g$ kriteriju (anketu) grupei $z$ kategorijos respondentų (ekspertu) suteiktas svorio koeficientas;

$\bar{Z}_{g}^{*}$ - visų tyrime dalyvavusių kategorijų respondentų ir ekspertų nuomonių apie $g$ kriterijų grupès svarbą vidutinis svorio koeficientas;

$\alpha$ - reikšmingumo lygmuo;

$\beta$ - koeficientas, priklausantis nuo maršruto tarpinių stočių skaičiaus; 
$\gamma$ - vèlavimo išvykti iš išvykimo (pradinès) stoties $A$ ir atvykti i galinę $C$ stotị svorio koeficientas;

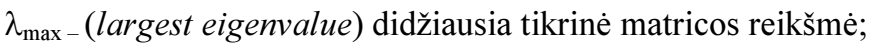

$v$ - laisvès laipsnis;

$\chi^{2}$ - konkordancijos koeficiento reikšmingumo kriterijus (Pirsono kriterijus);

$\chi_{\alpha, v}^{2}-$ kritinè Pirsono statistika;

$\omega$ - tikrinis vektorius;

$\sigma_{b}-$ bendrasis visų geometrinių parametrų standartinis nuokrypis;

$\sigma_{P L O T I S}-$ bėgių kelio vėžès pločio, išmatuoto prie 3-ios kelmačio vežimèlio ašies, standartinis nuokrypis;

$\sigma_{I D K}$ - kairès pusės bėgio įdubos standartinis nuokrypis;

$\sigma_{I D D}$ - dešinès pusès bègio įdubos standartinis nuokrypis;

$\sigma_{T I E K}-$ kairès pusès bègio padèties plane standartinis nuokrypis;

$\sigma_{T I E D}$ - dešinès pusès bègio padèties plane standartinis nuokrypis;

$\sigma_{L Y G I S}-$ bėgių padèties vienas kito atžvilgiu pagal bėgiu galvutès lygį standartinis nuokrypis;

$\sigma_{P E R}-$ staigaus nukrypimo pagal bėgiu galvutès lygi (perkrypa) standartinis nuokrypis.

\section{Santrumpos}

AHP - (angl. Analytic Hierarchy Process) daugiatikslio vertinimo metodas - analitinès hierarchijos procesas;

AKAK - keleivinio vagono ašidèžè ir ašies kakliukas;

EKS - elektroninis mokejjimo kortelių skaitytuvas;

ERTMS - (angl. European railway traffic management system) Europos geležinkeliu transporto valdymo sistemos;

ES - Europos Sajunga;

GGI - gaisro gesinimo įrenginys;

GPS - navigacijos sistemos įrenginys;

GSM-R - balsinio radijo ryšio ir bevielio duomenų perdavimo sistema;

IIA - individuali izoliuojančios apsaugos priemonè;

KAR - kapitalinis atkuriamasis remontas;

KDVM - kompleksinis daugiakriteris vertinimo modelis;

KKI - kelio kokybės indeksas;

KKVR - kompleksinis kokybès vertinimo rodiklis;

KTK - kelionès traukiniu kokybé;

$\mathrm{KV}$ - miegamasis 4-ių vietų kupè vagonas (36 vietos);

LG - AB ,Lietuvos geležinkeliai“; 
MV - miegamasis 2-jų vietų kupè vagonas (18 vietu);

TKVG - tarptautinis keleivių vežimas geležinkeliais;

TKVGK - tarptautinio keleivių vežimo geležinkeliais kokybė;

TKVGKK - tarptautinio keleivių vežimo geležinkeliais kokybès kriterijai (tikslą atspindintys efektyvumo rodikliai);

TKVGP - tarptautinio keleivių vežimo geležinkeliais procesas;

NVS - Nepriklausomų valstybių sandraugos šalys;

OSP-1 - automatinis miltelinis gesintuvas;

PGV - pavojingi gaisro veiksniai;

PV - paprastasis miegamasis vagonas (54 vietos);

RAKP - riedmenų automatinès kontrolès priemonès;

RITS - (angl. Railway Intelligent Transportation Systems) informacinèmis ir elektroninių ryšiu technologijomis grindžiamos sistemos, skirtos geležinkelių transporto eismui, iskaitant infrastruktūra, transporto priemones ir naudotojus, elektroninị keleivinio transporto bilieta, valdyti;

SMPS - Tarptautinio keleivių vežimo geležinkeliais susitarimas;

UPS - automatinis priešgaisrinès signalizacijos irenginys;

$\mathrm{WiFi}$ - nemokamas bevielis ryšys.

\section{Terminai ir apibrèžimai}

Dividendas [lot. dividendum - tas, kas turi būti dalijama] - dalis akcinès bendrovès pelno, padalyta akcininkams pagal nuo jų turimų akcijų kiekị ir rūšị.

Dotãcija [lot. dotatio - dovana, auka] - valstybès leešos, duodamos i̇monèms ir organizacijoms, vietiniams biudžetams, kad jie galètų padengti išlaidas, kurios viršija pajamas.

Ekspertas [lot. expertus - igudęs, prityręs] - mokslo, meno ar kitų sričių žinovas, kviečiamas atsakyti i klausimus, reikalaujančius specialių žinių.

Ekvivalentinis garso slègio lygis $\left(\mathrm{L}_{\mathrm{AeqT}}\right)$ - ekvivalentinis nuolatinis garso slègio lygis, kai standartine dažninè svertis yra A svertis.

Geležinkelio imonė (vežèjas) - licencijuota imonè, keleiviams, bagažui ir (ar) kroviniams vežti naudojanti viešają geležinkelių infrastruktūrą ir užtikrinanti trauką teisètai valdomomis traukos priemonėmis, taip pat imonè, kuri tik teikia traukos priemones.

Geležinkelio kelias - inžinerinis statinys, kurị sudaro žemès sankasa, viršutinè kelio konstrukcija (balasto sluoksnis, pabėgiai, bègiai) ir kiti inžineriniai irenginiai.

Geležinkelių infrastruktūra - geležinkeliai, statiniai, žemè, pastatai, pagrindinè iranga ir irenginiai, būtini eismui organizuoti ir valdyti bei eismo saugai užtikrinti.

Geležinkelių linija - geležinkelių tinklo dalis su irenginiais, statiniais bei eismo valdymo sistemomis.

Geležinkelio riedmenys - traukos priemonės (lokomotyvai), vagonai, dyzeliniai ir elektriniai traukiniai, automotrisès ir specialieji riedmenys. 
Geležinkelių tinklas - Lietuvos Respublikos geležinkelių infrastruktūra, kurią valdo ir prižiūri jos valdytojas ar savininkas.

Geležinkelių transportas - Lietuvos Respublikos ūkio ir socialinės infrastruktūros dalis, skirta visuomenès ir ūkio subjektu poreikiams tenkinti - keleiviams, bagažui ir (ar) kroviniams geležinkeliais vežti.

Geležinkelių transporto veikla - keleivių, bagažo ir (ar) krovinių vežimas geležinkeliais, geležinkelių infrastruktūros valdymas, plètra ir priežiūra, taip pat kita veikla, tiesiogiai susijusi su geležinkelių infrastruktūra, keleivių, bagažo ir (ar) krovinių vežimu.

Hierarchija [gr. hierarchija < hieros - šventas + archẽ - valdžia]: 1. Daugiapakopè organizacinè struktūra, kurios grandys, einant nuo viršaus i apačia, sudaro griežtai reglamentuotus pavaldumo ir priklausomybės laiptus; 2. Kibernetikoje - daugiapakopé struktūra.

Keleivinis traukinys - iš keleivinių vagonų suformuotas traukinys, vežantis keleivius, paštą ir bagaža.

Keleiviniai vagonai - vagonai keleiviams, paštui ir bagažui vežti, restorano vagonai, sanitariniai, tarnybiniai, tyrimo ir matavimo laboratorijos bei kiti specialūs keleiviniai vagonai.

Keleiviai - žmonès, keliaujantys traukinio sąstatu ir neatliekantys jokio su transportu susijusio darbo.

Kelionès bilietas - nustatytos formos dokumentas, patvirtinantis keleivio vežimo sutarties sudarymą ir suteikiantis teisę važiuoti traukiniu nuo / iki bet kurios stoties i vieną arba į abi puses pagal traukinio važiavimo maršruta.

Keleivių vežimo kokybè - vežimo proceso savybių visuma, kuri grindžiama jos galimybe patenkinti keleiviu poreikius.

Kokybiškas aptarnavimas - aptarnaujančiu darbuotojų mandagaus bendravimo, nepriekaištingos išvaizdos, keleivio lūkesčiu pateisinimo, keleiviui reikalingos informacijos suteikimo, probleminių situacijų operatyvaus išsprendimo derinys.

Kompensacija [lot. compensatio - išlyginimas] - nuostolių atlyginimas.

Konkordancija [lot. concordantis - dermė, sutikimas]: dvyniu požymių sutapimas.

Konkordantiškas [lot. concordans (kilm. concordantis) - atitinkantis] - panašus, turintis tokius pat būdingus požymius, darnus.

Lokomotyvo brigada - darbuotojų grupè, valdanti lokomotyva, dyzelini ar elektrinị traukini. Lokomotyvo brigadą sudaro mašinistas ir jo padejjejjas, o garvežiuose ir kūrikas.

Maksimalus garso slègio lygis $\left(\mathrm{L}_{\mathrm{AFmax}}\right)$ - didžiausiasis garso slègio lygis, kai standartinè dažninè svertis yra A svertis, o standartinè laiko svertis yra F svertis.

Maršrutas - traukinio ar manevrinio sąstato važiavimo per tam tikrus iešmus kelias iš tarpstočių i stoti, iš stoties ị tarpstotị arba iš vieno stoties kelio ị kita.

Nepastovus triukšmas - triukšmas, kuris nuolat kinta, pertrūksta arba pulsuoja ir kurio garso slègio lygio pokytis didesnis kaip $5 \mathrm{dBA}$.

Palydovas bufetininkas - darbuotojas, skiriamas aptarnauti bufeto vagonus ir restorano vagonus ir atsakantis už produktų kokybę, apskaita, asortimentą. 
Patogumas - malonus jausmas, kurį suvokia asmuo apie savo klimatinę aplinką.

Perkrypa - tai staigus bėgiu lygio pokytis i skirtingas puses, kai atstumas tarp gretimu nuokrypių viršūnių yra $20 \mathrm{~m}$ ar mažiau, neatsižvelgiant ị tai, ar irašo kreivè kerta nulinę linija, ar ne.

Procesas - tai tarpusavyje susijusių, vienas kitam itakos turinčių veiksnių visuma, t. y. tie veiksniai, kurie gavinius paverčia rezultatais (pvz., gavinys - kliento reikalavimai, procesas - naujo produkto kūrimas, rezultatas - naujas produktas).

Rangas [vok. Rang < pranc. rang - eilè] - hierarchijos lygmuo hierarchinèje sistemoje: ... 3. matematikoje, sistemos, kurios elementus galima sudeti vienus su kitais ir dauginti iš skaičių: tarpusavyje tiesiškai nepriklausomų elementų skaičiaus.

Reitingas [angl. rating] - sociologijoje - asmens, institucijos, reiškinio kiekybinis įvertinimas, padedantis palyginti vienos rūšies objektus, nustatyti jų vietą vertinimo skalèje.

Respondentas [lot. respondens - atsakantis] - asmuo, atsakinejjantis ị socialinių tyrimų anketas arba tyrèjo žodžiu užduodamus klausimus.

Savaitinis veikiančio triukšmo (triukšmo ekspozicijos) lygis ( $\mathrm{L}_{\mathrm{EX}}, 8 \mathrm{~h}, \mathrm{w}$ arba $\mathrm{L}_{\mathrm{EX}}, 8 \mathrm{~h}$ ): 5 dienų darbo savaitès kasdienių veikiančios triukšmo (ekspozicijų) svertinių lygių vidurkis.

Sistema - tam tikra tvarka sujungtų komponentų visuma.

Stotele - tarpstotyje įrengta vieta keleiviams išlipti iš traukinio ir įlipti i j ji.

Stotis - geležinkelio infrastruktūros dalis. Ją sudaro kelių, pastatų, statinių ir irenginių kompleksas, užimantis tam tikrą žemès sklypą ir skirtas traukiniams priimti, išformuoti, išleisti ir praleisti; keleiviams, bagažo ar krovinių siuntejjams (gavèjams) aptarnauti.

Subsidija [lot. subsidium - pagalba] - valstybès ekonominès (finansinès) pagalbos teikimas vietinès rinkos privačiam sektoriui arba kurios nors prekès (paslaugos) vartotojams.

Tranzityvumas - [tranzityvus]: ... 2. matematikoje: aibės elementų sąryšio savybė: jei a * $\mathrm{b}$ ir $\mathrm{b}^{*} \mathrm{c}$, tai a ${ }^{*} \mathrm{c}\left(\mathrm{a}, \mathrm{b}, \mathrm{c}\right.$ - aibès elementai, ${ }^{*}$ - sąryšio ženklas), pavyzdžiui, lygybè $(=)$, daugiau arba lygu $(\geq)$, mažiau arba lygu $(\leq)$ yra tranzityvūs sąryšiai.

Traukini aptarnaujantis personalas - traukiniais vykstančius keleivius aptarnaujantys darbuotojai: vagono palydovai, traukinio viršininkai, palydovai bufetininkai, konduktoriai kontrolieriai, elektrinio traukinio konduktoriai, revizoriai kontrolieriai.

Traukinio viršininkas - darbuotojas, skiriamas aptarnauti keleivinius traukinius, kuriam pavaldi traukinio brigada ir atsakantis už pavaldžių darbuotojų darbo organizavima, saugų keleivių vežimą savo kompetencijos ribose, kultūringą aptarnavimą ir keleivinių vagonų eksploatavimą.

Vagono palydovas - darbuotojas, skiriamas aptarnauti keleivinius vagonus, atsakantis už saugų keleivių vežima, kultūringą aptarnavima, vagono inventorių, irangą ir kitas vertybes.

Vyresnysis vagono palydovas - darbuotojas, skiriamas aptarnauti keleivinius traukinius ir traukinio viršininko poilsio metu einantis jo pareigas. 


\section{Turinys}

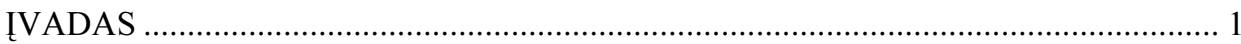

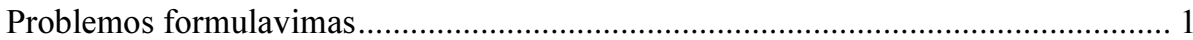

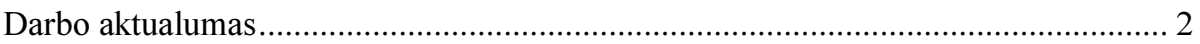

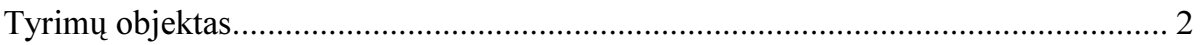

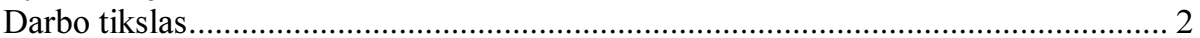

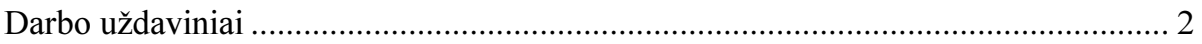

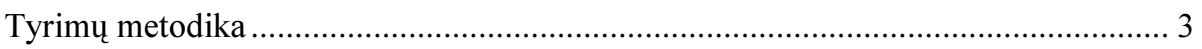

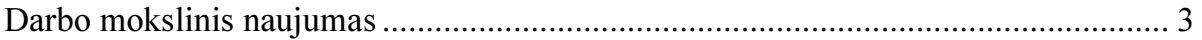

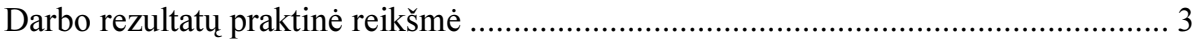

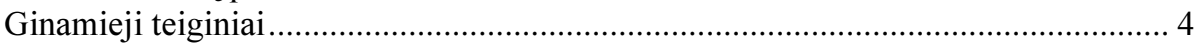

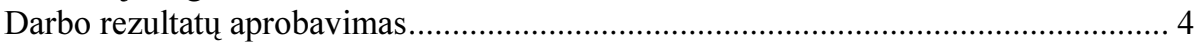

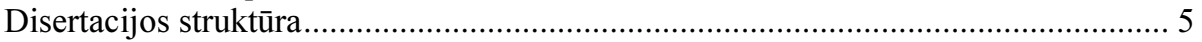

1. MOKSLO DARBŨ, SKIRTŲ KELEIVIŲ VEŽIMO GELEŽINKELIAIS KOKYBEI TIRTI IR JĄ REGLAMENTUOJANČIŲ DOKUMENTŲ,

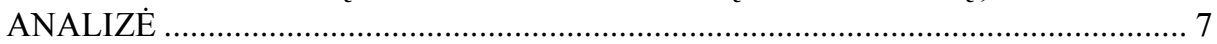

1.1. Keleivių vežimo geležinkeliais kokybę reglamentuojantys dokumentai .............. 7

1.2. Geležinkelio infrastruktūros tyrimai............................................................ 12

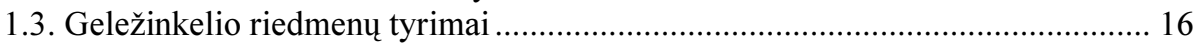

1.4. Keleivių vežimo geležinkeliais proceso tyrimai ................................................ 17

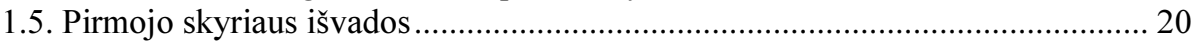




\section{KELEIVIŲ VEŽIMO GELEŽINKELIAIS KOKYBĖS KRITERIJAI IR}

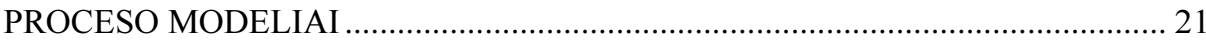

2.1. AB „Lietuvos geležinkeliai“ veiklos ir keleivių vežimo rodiklių apžvalga........ 21

2.2. Kelionės tarptautiniu traukiniu kokybės kriterijų pagrindimas ir sisteminimas 25

2.2.1. Kriterijai, susieti su traukinio elementais ir geležinkelio kelio technine būkle

2.2.2. Kriterijai, susieti su kelionès traukiniu proceso organizavimu ir

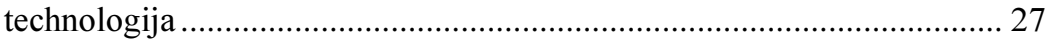

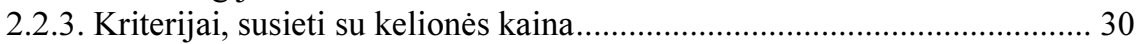

2.2.4. Kriterijai, susieti su kelionès traukiniu saugumu.................................... 30

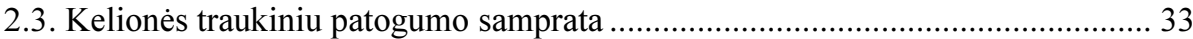

2.4. Kelionès traukiniu proceso modelis ir jo pagrindimas ...................................... 35

2.4.1. Kriterijų, susietų su traukinio elementais ir geležinkelio kelio technine būkle, vertinimo modelis ........................................................ 35

2.4.2. Kriteriju, susietų su kelionès traukiniu proceso organizavimu ir

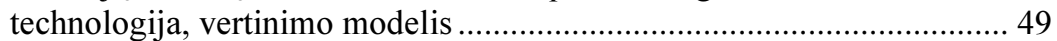

2.4.3. Kriterijų, susietų su kelionès kaina, vertinimo modelis............................. 62

2.4.4. Kriterijų, susietų su kelionės traukiniu saugumu, vertinimo

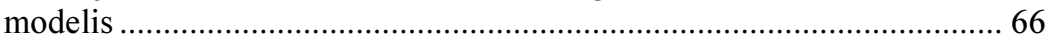

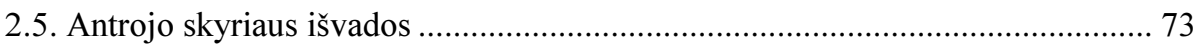

3. KELEIVIŲ VEŽIMO GELEŽINKELIAIS KOKYBĖS KRITERIJŲ IR JŲ GRUPIŲ SVARBOS TYRIMAS EKSPERIMENTINIAIS METODAIS ……............ 75

3.1. Keleivių vežimo geležinkeliais kokybès kriterijų svarbos tyrimas AHP

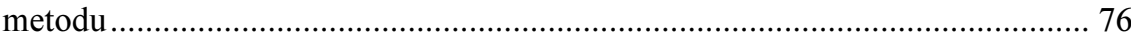

3.1.1. Anketų struktūra, respondentai ir ekspertai ............................................. 76

3.1.2. Vieno eksperto nuomonès apie kriterijų svarbą nustatymas....................... 77

3.1.3. Anketos duomenų tvarkymo skaitinis pavyzdys ....................................... 79

3.1.4. Grupès respondentų ir ekspertų nuomonių suderinamumas ....................... 83

3.1.5. Respondentu (keleiviu) nuomoniu suderinamumo skaitinis

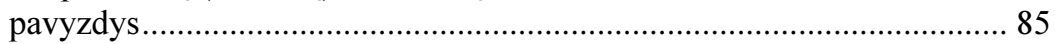

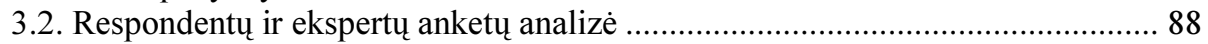

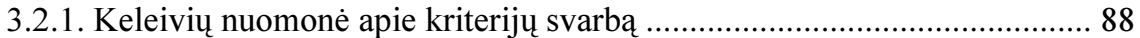

3.2.2. Traukini aptarnaujančio personalo nuomonė apie kriterijų

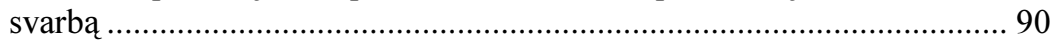

3.2.3. Administracijos darbuotojų nuomoné apie kriterijų svarbą....................... 92

3.2.4. Trijų kategorijų tyrime dalyvavusių respondentų ir ekspertų lyginamoji nuomonių analizè

3.3. Respondentų ir ekspertų, nustačiusių kelionės traukiniu kokybès kriteriju grupių svarba, apklausos rezultatai ir nuomonių lyginamoji analizè................. 100

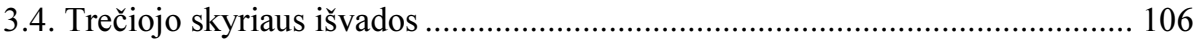

4. MODELIU TAIKYMAS VERTINANT KELEIVIŲ VEŽIMO GELEŽINKELIAIS KOKYBĘ 109 
4.1. Kriterijų, susietų su traukinio elementais ir geležinkelio kelio technine būkle, modelio praktinio pritaikymo vertinimas.

4.2. Kriterijų, susietų su kelionès traukiniu proceso organizavimu ir technologija, modelio praktinio pritaikymo vertinimas

4.3. Kriterijų, susietų su kelionès kaina, modelio praktinio pritaikymo vertinimas

4.4. Kriterijų, susietų su kelionès traukiniu saugumu, modelio praktinio pritaikymo vertinimas.

4.5. Kriterijų kitimo įtakos kompleksiniam kokybės rodikliui tyrimas ................... 138

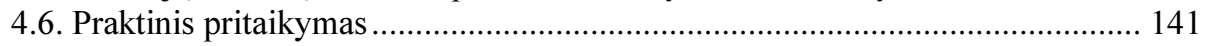

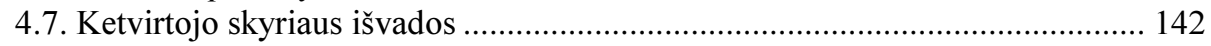

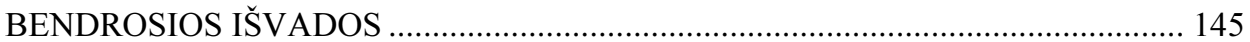

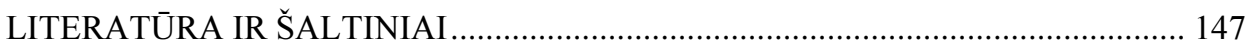

AUTORĖS PUBLIKACIJŲ DISERTACIJOS TEMA SĄRAŠAS …............................ 161

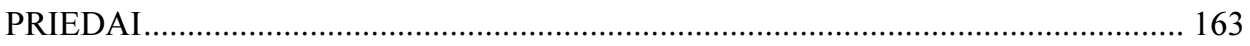

A priedas. Kriterijų, susietu su kelionès traukiniu proceso organizavimu ir technologija, kiekybinio įvertinimo (balo) 1-ojo respondento nustatymo anketa.

B priedas. A, B, C ir D grupių kriterijų svarbos nustatymas ir rangavimas pagal keleivių nuomonę

C priedas. A, B, C ir D grupių kriterijų svarbos nustatymas ir rangavimas pagal traukini aptarnaujančio personalo nuomonę.

D priedas. A, B, C ir D grupių kriterijų svarbos nustatymas ir rangavimas pagal administracijos darbuotojų nuomonę.

E priedas. Kelionės traukiniu kokybės A, B, C ir D kriterijų grupių svarbos (pirmumo) nustatymo anketa (su 1-ojo respondento suteiktais rangais).

F priedas. Kelionès traukiniu kokybės kriterijų A, B, C ir D grupiu pirmumo ivertinimas $R_{i j}$ (rangai) respondentų ir ekspertų požiūriu....

G priedas. Svarbiausių Lietuvos Respublikos geležinkelio kelių KKI, išmatuoto kelmačiu EM-140 (kas kilometras) 2012 m. vasariogegužès mènesiais, kitimas ir jo atitiktis normų reikalavimams

H priedas. Kelmačiu EM-140 2012 m. išmatuotų kelių kokybès indekso (KKI) reikšmių pasiskirstymas (dinamika)

I priedas. Kelmačiu EM-140 2012 m., išmatuotų kelių kokybės indekso (KKI) reikšmiu procentinis pasiskirstymas (dinamika)

J priedas. Kelio Vilnius-Kena (I pagrindinio) 2012 m. sausio mèn. išmatuoti

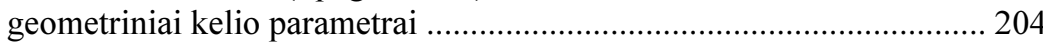

K priedas. Traukinio Vilnius-Maskva tvarkaraštis ................................................. 206

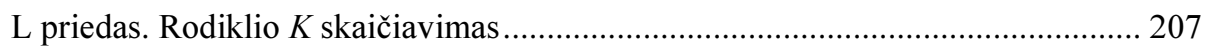




\section{Contents}

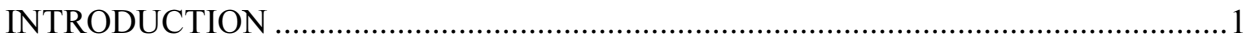

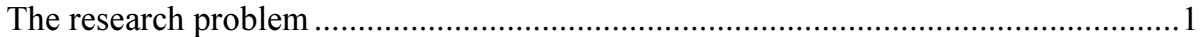

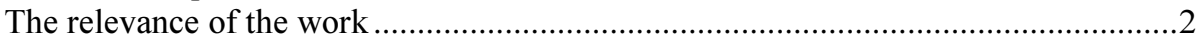

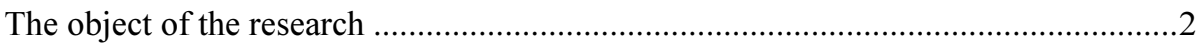

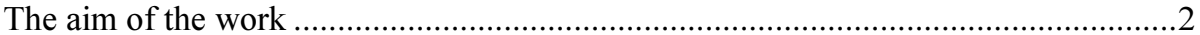

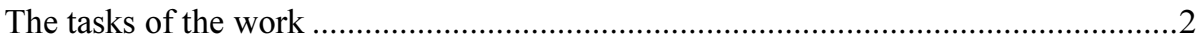

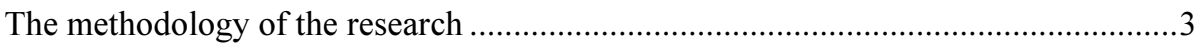

The scientific novelty ……....................................................................................

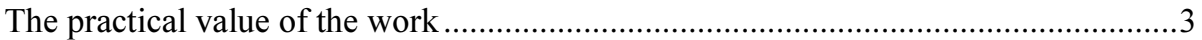

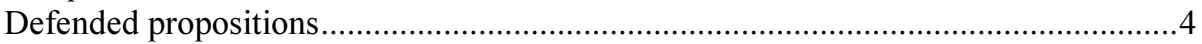

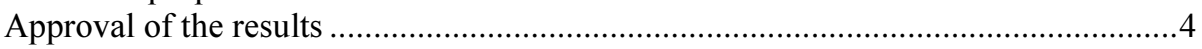

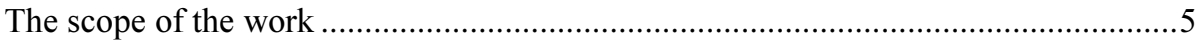

1. THE ANALYSIS OF THE WORKS DEVOTED TO THE INVESTIGATION OF THE QUALITY OF PASSENGER TRANSPORTATION BY RAILWAY AND THE DOCUMENTS REGULATING IT ……….........................................

1.1. The documents, regulating the quality of passenger transportation by

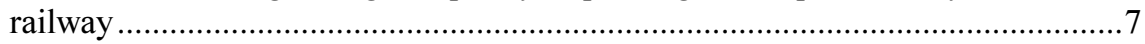

1.2. The research works on railway infrastructure ....................................................... 12

1.3. The research works on rolling stock ............................................................... 16

1.4. The research works on the process of passenger transportation by railway ........17

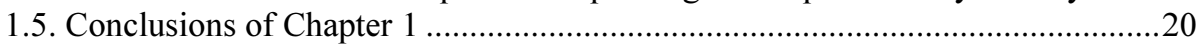




\section{THE CRITERIA DESCRIBING THE QUALITY OF PASSENGER}

TRANSPORTATION BY RAILWAY AND MODELS OF THIS PROCESS

2.1. A survey of the activities of the $A B$ "Lietuvos geležinkeliai" and passenger transportation criteria

2.2. Theoretical substantiation and classification of the criteria describing the quality of trip by international trains

2.2.1. The criteria describing the elements of the train and the railway track condition

2.2.2. The criteria describing the organization and technology of the process of travelling by train .........................................................2

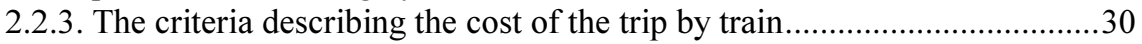

2.2.4. The criteria describing the safety of the trip by train...............................30

2.3. A concept of comfort of the trip by train ........................................................33

2.4. The model of the process of travelling by train and its substantiation ..................35

2.4.1. The model for evaluating the criteria describing the elements of the train and the condition of the railway track

2.4.2. The model for evaluating the criteria describing the organization and technology of the process of travelling by train

2.4.3. The model for evaluating the criteria describing the cost of the trip by train

2.4.4. The model for evaluating the criteria describing the safety of the trip by train

2.5. Conclusions of Chapter 2 .....

3. THE ANALYSIS OF THE SIGNIFICANCE OF THE CRITERIA AND THEIR GROUPS, DESCRIBING THE QUALITY OF PASSENGER TRANSPORTATION BY RAILWAY, BASED ON EXPERIMENTAL METHODS

3.1. Investigation of the significance of the criteria describing the quality of passenger transportation by railway using AHP method

3.1.1. The description of the structure of the questionnaires, respondents and experts

3.1.2. Determination of the opinion of one particular expert about the significance of the criteria

3.1.3. The numerical example of the questionnaire's data processing

3.1.4. The consistency of the opinions of the group of respondents and experts

3.1.5. The numerical example of the consistency of the opinions of respondents (passengers)

3.2. The analysis of the questionnaires obtained from the respondents and experts

3.2.1. The opinion of the passengers of the train about the significance of the criteria.

3.2.2. The opinion of the service staff of the train about the significance of the criteria 
3.2.3. The opinion of the administration staff about the significance of the criteria.

3.2.4. The comparative analysis of the opinions of three categories of respondents and experts, taking part in the survey

3.3. The results obtained from the respondents and experts in the survey, conducted for determining the significance of the criteria group, describing the quality of the trip by train, and the comparative analysis of their opinions

3.4. Conclusions of Chapter 3

4. THE APPLICATION OF MODELS FOR EVALUATING THE QUALITY OF PASSENGER TRANSPORTATION BY RAILWAY

4.1. The application of the model for evaluating the criteria, describing the elements of the train and the condition of the railway track.

4.2. The application of the model for evaluating the criteria, describing the organisation and technology of the process of travelling by train

4.3. The application of the model for evaluating the criteria, describing the cost of the trip by train

4.4. The application of the model for evaluating the criteria, describing the safety of the trip by train

4.5. Investigating the impact of the variation of the considered criteria on the comprehensive quality index

4.6. Practical application

4.7. Conclusions of Chapter 4

GENERAL CONCLUSIONS

REFERENCES

THE LIST OF PUBLISHED WORKS ON THE TOPIC OF THE DISSERTATION....

ANNEXES (ON THE CD)

Annex A. The questionnaire of the first respondent for quantitative evaluation (in points) of the criteria describing organization and technology of the process of travelling by train

Annex B. Determining the significance of the criteria of the groups A, B, C and $\mathrm{D}$ and their ranking, based on the opinions of passengers

Annex C. Determining the significance of the criteria of the groups A, B, C and $\mathrm{D}$ and their ranking, based on the opinions of the train service staff.

Annex D. Determining the significance of the criteria of the groups A, B, C and $\mathrm{D}$ and their ranking, based on the opinions of the administration staff 
Annex E. The questionnaire with the ranks, assigned by the first respondent for determining the significance (preference order) of the criteria of the groups $\mathrm{A}, \mathrm{B}, \mathrm{C}$ and $\mathrm{D}$, describing the quality of the trip by train

Annex F. Ranking $\left(\mathrm{R}_{\mathrm{ij}}\right)$ the criteria of the groups $\mathrm{A}, \mathrm{B}, \mathrm{C}$ and $\mathrm{D}$, describing the quality of the trip by train, based on the opinions of respondents and experts

Annex G. The variation of the TQI of the main Lithuanian railways, measured by the track geometry car EM-140 (for each km) in February-May, 2012, and its compliance with the accepted standards

Annex H. Distribution (dynamics) of TQI values, measured by the track geometry car EM-140 in 2012

Annex I. Percent distribution (dynamics) of TQI values, measured by the track geometry car EM-140 in 2012

Annex J. Geometric parameters of the railway track (the main track 1) on the route Vilnius-Kena, measured in January, 2012.

Annex K. The schedule of the train Vilnius-Moscow .206

Annex L. Calculating of index $K$ .207 


\section{Ivadas}

\section{Problemos formulavimas}

Ar gali būti taip, kad XXI amžiuje Lietuvoje išnyks keleivių vežimo geležinkeliais sektorius? Toks scenarijus, kadaise atrodęs nerealus, Lietuvai įžengus i atvirą Europa, virsta realybe. Šiuo metu stinga lèšų keleivinių traukinių riedmenų parkui atnaujinti, kurios yra būtinos keleivių vežimo paslaugos kokybei užtikrinti. Atsiradus pigioms avialinijoms dalis tarptautinių traukinių keleivių pasirinko lekktuvus, kadangi bilieto kaina beveik prilygsta traukinio bilieto kainai, o kelionès tikslas pasiekiamas daug greičiau. Norint, kad keleivių vežimas būtų pelningas, būtina 6 kartus padidinti kainas arba $100 \%$ pripildyti traukinius. Tam, kad geležinkelių transportas rinkoje sèkmingai konkuruotų su kitomis transporto rūšimis, būtina gerinti vežimo proceso kokybę.

Disertacijoje pateikiami tarptautinio keleivių vežimo geležinkeliais kokybės kriterijai (TKVGKK). Ekspertinių vertinimų metodais nustatytas atskirų kriterijų grupių ir jas sudarančių kriterijų reikšmingumas (svoriai). Pateiktas daugiatikslis matematinis modelis, kurị taikant galima apskaičiuoti kelionès tarptautiniu traukiniu 49 kokybės kriterijų itaką keleivių vežimo kokybei, išreiškiamai vienu parametru (kompleksiniu kokybės vertinimo rodikliu (KKVR) $K$ ). 


\section{Darbo aktualumas}

Mokslineje literatūroje stokojama sprendinių, kuriais remiantis galima ivvertinti kelionès tarptautiniu traukiniu kokybę.

Siekdama išlaikyti ir pagerinti vietą konkurencineje rinkoje su kelių ir oro transportu, geležinkelio imonė priversta ieškoti būdų, kaip padidinti patoguma, saugumą traukiniuose. Dèl šios priežasties kyla būtinybè nustatyti keleiviui svarbius kelionès traukiniu kriterijus ir juos gerinti. Kelionès traukiniu proceso veiksniai (kriterijai) skirtingai veikia keleivio patoguma, saugumą, važiavimo trukmę, kainą ir pasitenkinimą kelione. Atskirų traukinių, kelionės traukiniu ruožų, aptarnaujančio personalo darbo kokybę patogu vertinti vienu parametru, t. y. KKVR $K$.

\section{Tyrimų objektas}

Tyrimų objektas - keleivių vežimo geležinkeliais procesas ir ji rodantys parametrai (kriterijai).

\section{Darbo tikslas}

Šio darbo tikslas - pateikti tarptautinio keleivių vežimo geležinkeliais kokybès kriterijų visumą, jų vertinimo daugiatikslius modelius.

\section{Darbo uždaviniai}

Darbo tikslui pasiekti reikia išspręsti šiuos uždavinius:

1. Suformuluoti ir susisteminti kriterijus, turinčius įtakos tarptautinio keleivių vežimo geležinkeliais kokybei, nustatyti jų svori.

2. Nustatyti kiekvienos kriterijų grupès svarbą (pirmumą) ir grupès kriterijų svarbą.

3. Pateikti originalų matematinị modelị, leisiantị ịvertinti tarptautinio vežimo kokybès vienareikšmį kiekybinį rodiklį.

4. Eksperimentiniais tyrimu duomenimis patikrinti pateikto modelio korektiškumą ir nustatyti kriterijų kitimo itaką kompleksiniam kokybès vertinimo rodikliui, išreiškiamam koeficientu $K$.

5. Pateikti moksliniais tyrimais pagrịstas išvadas ir rekomendacijas, leisiančias pagerinti tarptautinio keleivių vežimo geležinkeliais kokybę. 


\section{Tyrimų metodika}

Tyrimų metodika pagrista mokslinių darbu šioje srityje analize. Darbe naudojami ekspertiniu tyrimu, matematinès statistikos, daugiakriterio vertinimo metodai, atliktas rezultatu palyginimas ir ekspertinis vertinimas. Panaudoti apklausuc, atliktu LG tarptautinio susisiekimo traukinyje Vilnius-Maskva vagono vidaus ir ašidèžių temperatūros matavimų metu gauti ir kelmačiu EM-140 išmatuoti Lietuvos geležinkelio kelių duomenys.

\section{Darbo mokslinis naujumas}

TKVGK kiekybiniai parametrai beveik netyrinèti, todèl rengiant disertaciją buvo gauti šie transporto inžinerijos mokslui nauji rezultatai:

1. Pasitelkus kiekybinius vertinimo metodus nustatyta TKVGKK svarba.

2. Analitiniu Hierarchijos Proceso (AHP) metodu atlikus skirtingu kategorijų vertintojų ekspertų (traukini aptarnaujančio personalo ir AB „Lietuvos geležinkeliai“ Keleivių vežimo direkcijos administracijos darbuotojų) ir respondentų (keleivių) anketinę apklausą gauti objektyvūs skaitiniai îverčiai, rodantys TKVGKK ir jų grupių svarba.

3. Pateiktas originalus daugiatikslis matematinis modelis, kuri taikant galima nustatyti kelionès traukiniu kokybès kriterijų itaką keleivių vežimo kokybei, kelionès atskirais tarptautiniais traukiniais kokybę vertinti kompleksiškai vienu parametru, t. y. KKVR. Jo adekvatumas (korektiškumas) patikrintas ir patvirtintas remiantis atliktu eksperimentu ir skaičiavimų duomenimis. Nustatyta kriterijų kitimo itaka KKVR, t. y. modelio jautrumas.

4. Pirmą kartą keleivių vežimo geležinkelių transportu kokybiniai parametrai vertinami taikant rangu, porinio lyginimo ir daugiatikslio vertinimo metodus.

\section{Darbo rezultatų praktinè reikšmè}

1. Suformuluoti ir susisteminti kriterijai, turintys itakos TKVGK, nustatyti jų ir šių kriterijų grupių reikšmingumai. Tyrimų rezultatai gali būti naudojami atskiriems kriterijams ir visam keleivių vežimo tarptautiniu traukiniu procesui gerinti. 
2. Sukurtas originalus adityvinis modelis, skirtas atskiro tarptautinio traukinio (maršruto) KKVR skaičiuoti ir nustatytas jo jautrumas. Patikrintas jo korektiškumas vertinant tarptautinio traukinio Vilnius-Maskva KKVR.

\section{Ginamieji teiginiai}

1. Keleivių vežimo traukiniu kokybę, priklausančią nuo daugelio kriterijų, galima vertinti vienu parametru, nustatomu iš adityvinio modelio. Taikant adityvinį modelị galima lyginti atskirus tarptautinio traukinio maršrutus.

2. KKVR modelį sudaro skirtingą svorị turintys 4 dèmenys, kurių kiekvienas skaičiuojamas sudedant kriterijaus normalizuoto svorio ir jo kintamosios dalies sandaugas. Ne visi TKVGKK yra vienodai svarbūs keleiviams, traukini aptarnaujančiam personalui ir administracijos darbuotojams.

3. Kriterijų normalizuotus svorius ir jų grupių pirmumą patogu nustatyti taikant ekspertinių tyrimų metodus: AHP, rangų koreliacijos (angl. Rank Correlation).

4. Kriterijai, kuriu kintamosios dalies pokytis nuo 0 iki 1 labiausiai keičia KKVR vertę, laikytini svarbiausiais.

\section{Darbo rezultatu aprobavimas}

Disertacijos tema yra išspausdinti 9 moksliniai straipsniai: 2 - referuojamuose ir turinčiuose citavimo indeksą Mokslinès informacijos instituto duomenu bazèje „Thomson ISI Web of Science“ (tarptautiniuose mokslo leidiniuose) mokslo žurnaluose; 2 - mokslo leidiniuose, referuojamuose Mokslinès informacijos instituto duomenų bazejje „Thomson ISI Web of Science“ be citavimo indekso; 2 - konferencijų pranešimų medžiagose; 1 - recenzuojamame mokslo žurnale, referuojamame Lietuvos Respublikos švietimo ir mokslo ministerijos iskaitomoje duomenų bazèje „IndexCopernicus“; 1 - kitame recenzuojamame mokslo leidinyje; 1 - nerecenzuojamame leidinyje paskelbtas straipsnis (konferencijos pranešimų medžiagoje).

Disertacijoje atliktų tyrimų rezultatai buvo paskelbti 5 mokslinèse konferencijose:

- Jaunujų mokslininkų konferencijoje „Mokslas - Lietuvos ateitis“ 2008, 2009, $2011 \mathrm{~m}$. Vilniuje, Lietuvoje (3);

- Tarptautineje konferencijoje „Environment Engineering“ 2011 m. Vilniuje, Lietuvoje (1); 
- Tarptautinejje konferencijoje „Oro uostai - langas i ateitį“ 2012 m. Kijeve, Ukrainoje (1).

\section{Disertacijos struktūra}

Disertaciją sudaro įvadas, 4 skyriai, bendrosios išvados, literatūros sąrašas, publikacijų sąrašas ir 12 priedų.

Darbo apimtis - 165 puslapiai be priedų. Tekste panaudota: 97 numeruotos formulès, 38 paveikslai ir 22 lentelès. Rašant disertaciją vadovautasi 188 mokslinès literatūros ir kitais šaltiniais. 



\section{1}

\section{Mokslo darbų, skirtų keleivių vežimo geležinkeliais kokybei tirti ir ją reglamentuojančių dokumentų, analizè}

Geležinkelių transportas, konkuruodamas vežimų rinkoje su kitomis transporto rūšimis, sparčiai tobulèja - dideja važiavimo greitis, patogumas, saugumas.

Skyriuje nagrinejjami moksliniai darbai, skirti geležinkelių infrastruktūrai, riedmenims ir keleivių vežimo geležinkeliais proceso kokybei tirti, analizuojami keleivių vežimo geležinkeliais kokybę Lietuvos Respublikoje ir kitose ES šalyse reglamentuojantys norminiai dokumentai.

\subsection{Keleivių vežimo geležinkeliais kokybę reglamentuojantys dokumentai}

Lietuvos Respublikoje keleivių vežimo geležinkeliais kokybę reglamentuoja ịvairūs dokumentai. Lietuvos Respublikoje keleivių vežimo geležinkeliais kokybę reglamentuojančių dokumentu schema pavaizduota 1.1 paveiksle. Geležinkelių transportas veikia pagal Lietuvos Respublikos geležinkeliu transporto kodeksa 
(2002), Lietuvos Respublikos tarptautines sutartis, Lietuvos Respublikos istatymus, Vyriausybès nutarimus bei Susisiekimo ministerijos teisès aktus. Lietuvos Respublikos geležinkelių transporto kodeksas reguliuoja santykius, kylančius iš keleivių, bagažo ir krovinių vežimo Lietuvos Respublikos geležinkelių transportu, nustato keleivių, krovinių siuntèjų (gavèjų) ir vežèjų teises, pareigas ir atsakomybę, reikalavimus geležinkelio i̇monès specialistams, taip pat geležinkelio infrastruktūros objektų reikalavimus. AB ,Lietuvos geležinkeliai“ darbuotoju etikos kodeksas (2008) nustato LG darbuotoju elgesio principus bei taisykles, reguliuoja darbuotojų tarpusavio santykius bei santykius su kitais asmenimis. Techninio geležinkeliu naudojimo nuostatai (1966) nustato $1520 \mathrm{~mm}$ pločio vèžès geležinkelių veiklos pagrindus, pagrindinių statinių, irenginių ir riedmenų matmenis, reikalavimus, priežiūros normas ir traukinių eismo organizavimo bei signalizavimo principus. Geležinkeliu eismo taisyklès (2000) nustato traukinių eismo tvarkymo principus, traukiniu prièmimo i stoti, išleidimo i tarpstoti ir manevravimo stotyje tvarką. Nurodo geležinkelių transporto darbuotojų veiksmus susidarius avarinei ir nestandartinei situacijai bei sutrikus eismo valdymo įrenginių sistemai. Prieigos taisykless, taikomos vežant neigalius ir ribotos judèsenos asmenis, sukurtos remiantis $2007 \mathrm{~m}$. spalio $23 \mathrm{~d}$. Europos Parlamento ir Tarybos reglamento (EB) Nr. 1371/2007 dèl geležinkelių keleivių teisių ir pareigų nuostatomis ir taikomos teikiamoms $\mathrm{AB}$ „Lietuvos geležinkeliai“ paslaugoms vežant neigalius ir ribotos judèsenos asmenis Lietuvos teritorijoje bei tarptautiniais maršrutais. Taisyklių paskirtis - užtikrinti lygias ir nediskriminacines galimybes žmonèms su judejjimo bei kitomis negaliomis - dèl amžiaus arba bet kurios kitos priežasties - keliauti geležinkelių transportu, skiriant ypatingą dèmesi informacijos, kuri susijusi su geležinkelio paslaugu pritaikymu, su galimybe patekti $\mathfrak{i}$ traukinius ir naudotis juose esančiais patogumais, teikimu. Keleivių, nešulių ir bagažo vežimo Lietuvos geležinkeliais vietinio susisiekimo traukiniais tvarką, kurios privalo laikytis geležinkelio imonè, keleiviai ir bagažo siuntejai bei gavejjai, nustato Bendrosios keleiviu vežimo taisyklès (2012). Šios taisyklès yra vežimo sutarties sudedamoji dalis ir yra parengtos pagal šių teisès aktų aktualias redakcijas:

- 2007 m. spalio $23 \mathrm{~d}$. Europos Parlamento ir Tarybos reglamentą (EB) Nr. 1371/2007 dèl geležinkelių keleivių teisių ir pareigų;

- Lietuvos Respublikos geležinkelių transporto kodeksą;

- Lietuvos Respublikos civilinį kodeksa;

- Lietuvos Respublikos transporto lengvatu istatyma;

- kitus teisès aktus.

Keleivių nešulių ir bagažo vežimo tarptautiniais traukiniais tvarką nustato Susitarimas dèl keleiviu vežimo tarptautiniame susisiekime (1997). AB „Lietuvos geležinkeliai “ Keleiviu vežimo direkcijos keleiviu aptarnavimo standartas (2012), parengtas vadovaujantis Lietuvos Respublikos darbo kodeksu, AB „Lietuvos geležinkeliai" darbuotojų etikos kodeksu bei kitais bendrovès teisès aktais. 


\section{KELEIVIŲ VEŽIMO GELEŽINKELIAIS KOKYBĘ LIETUVOS RESPUBLIKOJE REGLAMENTUOJANTYS DOKUMENTAI}

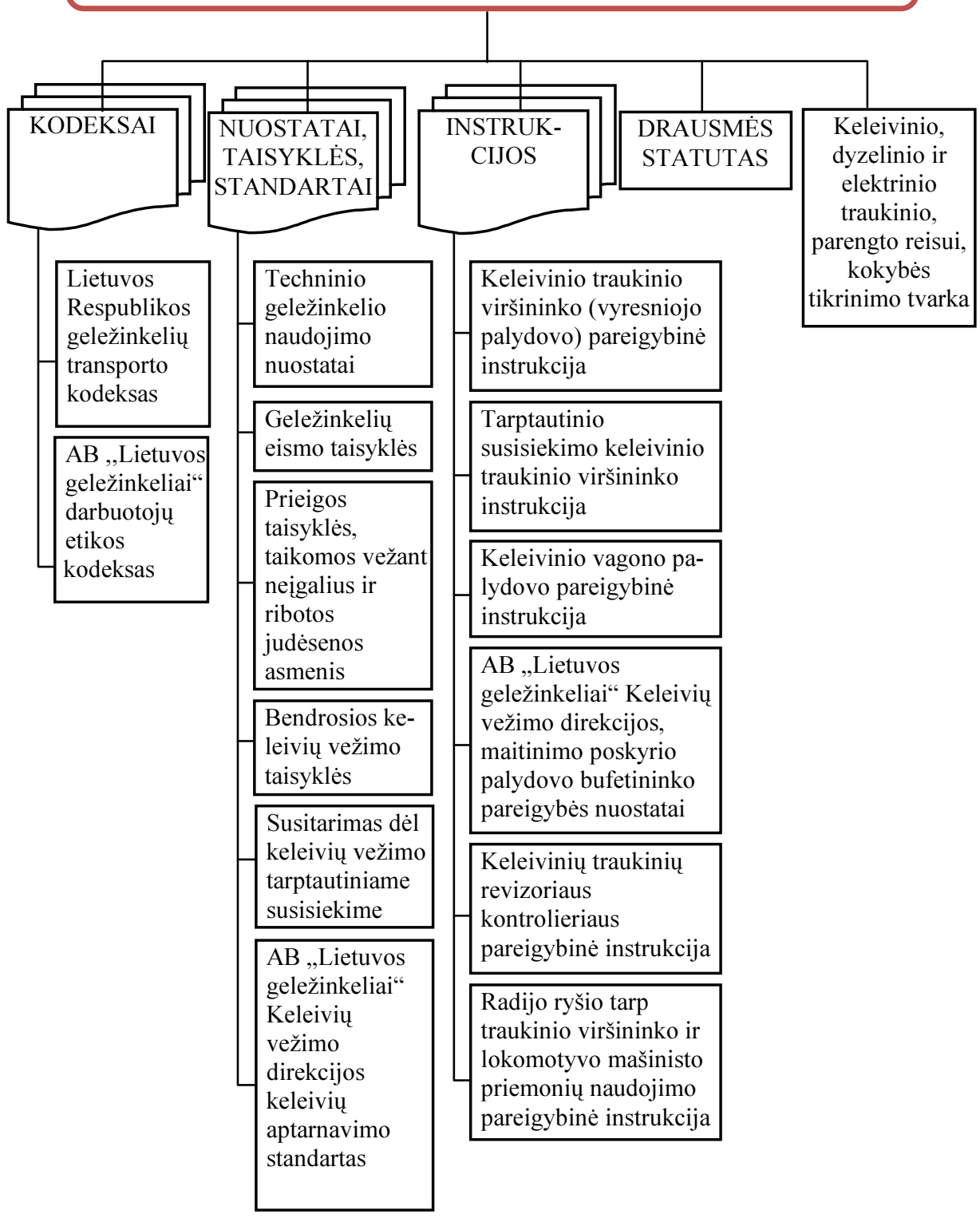

1.1 pav. Keleivių vežimo geležinkeliais kokybę Lietuvos Respublikoje reglamentuojančių dokumentų schema

Fig. 1.1. A scheme showing Lithuanian documents regulating the quality of passenger transportation by railway 
$A B$,Lietuvos geležinkeliai“ Keleivių vežimo direkcijos keleivių aptarnavimo standartas - vidinis dokumentas, nustatantis pagrindinius aptarnaujančių darbuotojų elgesio principus bei taisykles aptarnaujant geležinkelių transporto keleivius, išvaizdos darbe reikalavimus, bendravimo su keleiviais ypatumus, apibrèžiantis kokybiško aptarnavimo supratimą bei jo igyvendinimą.

Traukini aptarnaujančių darbuotojų instrukcijos nustato jų pareigas, kurių deramas atlikimas užtikrina saugų traukinio eismą, kultūringą keleivių aptarnavimą. Keleivinio traukinio viršininko (vyresniojo palydovo) pareiginé instrukcija (2001) nustato keleivinio traukinio viršininko pareigas prieš reisa, kelionès metu, grąžos bei formavimo stotyse. Ši instrukcija taip pat nustato traukinio viršininko veiksmus avarijos ir kitais išskirtiniais atvejais, pasienio ir muitinès kontrolès stotyse, jo teises ir atsakomybę. Tarptautinio susisiekimo keleivinio traukinio viršininko instrukcija (2003) yra pagrindinis dokumentas, reglamentuojantis traukinių viršininkų pareigas NVS šalių, Latvijos Respublikos, Lietuvos Respublikos, Estijos Respublikos ir kitu šalių, per kurias važiuoja traukinys, geležinkeliuose. Keleivinio vagono palydovo pareigine instrukcija (1999) nustato keleivinio vagono palydovo pareigas prieš reisa, kelionės metu, grąžos bei formavimo stotyse. Ši instrukcija taip pat nustato palydovo veiksmus avarijos ir kitais išskirtiniais atvejais, palydovo veiksmus pasienio ir muitinès kontrolès stotyse, elgesio taisykles, teises ir atsakomybę bei tarptautinio susisiekimo traukinio vagono palydovo veiksmus. AB ,Lietuvos geležinkeliai“ Keleiviu vežimo direkcijos maitinimo poskyrio palydovo bufetininko pareigybès nuostatai nustato palydovų bufetininkų uždavinius ir funkcijas, teises, atsakomybę ir ryšius. Keleiviniu traukiniu revizoriaus kontrolieriaus pareigine instrukcija nurodo revizorių kontrolierių pareigas tikrinant keleivius, restorano ir bagažo vagonus, tikrinimo rezultatų iforminimo tvarka, jų veiksmus prieš reisą ir po reiso. Radijo ryšio tarp traukinio viršininko ir lokomotyvo mašinisto priemoniu naudojimo instrukcija (1999) nustato radijo ryšio tarp keleivinio traukinio viršininko ir lokomotyvo mašinisto irengimo tvarka, naudojimo taisykles, pokalbių reglamentą. Radijo ryšys naudojamas tarnybiniams pokalbiams tarp traukinio viršininko ir lokomotyvo mašinisto eismo saugumui, keleivių aptarnavimo kultūrai ir kokybei gerinti. Geležinkelių transportas - viena iš svarbiausių Lietuvos Respublikos transporto sistemos dalių. Kad geležinkelių transportas dirbtų darniai, kad keleiviai bei kroviniai laiku būtų pristatomi i paskirties vietą ir užtikrinamas eismo saugumas, geležinkelių transporto darbuotojai privalo dirbti dorai ir sąžiningai, laikytis darbo drausmès, laiku ir tiksliai atlikti vadovu pavedimus, laikytis technologinès ir gamybinès drausmès, saugos darbe reikalavimu, nepalikti darbo vietos, kol jų nepakeičia kiti darbuotojai. Lietuvos geležinkeliu transporto darbuotoju drausmès statutas (1995) nustato AB „Lietuvos geležinkeliai“ darbuotojų, kurių veikla gali sukelti šios i̇monès darbo sutrikimus, susijusius su didelio masto avarijomis, jų sunkiais padariniais žmonèms ir gamtai, darbo sutarties bei 
drausminès atsakomybės ypatumus, darbuotojų skatinimo tvarką. Keleivinio, dyzelinio ir elektrinio traukinio, parengto reisui, kokybès tikrinimo tvarka (2004) reglamentuoja traukinio parengima, laikantis technologinių reikalavimų prieš nukreipimą į išvykimo kelią ilaipinti keleivius, siekiant užtikrinti jų saugų vežimą ir kultūringą aptarnavimą kelionès metu bei keleivinių traukinių riedmenų vidaus garso ir vaizdo informacijos priemonių (keleivių ir bagažo vežimo geležinkelių transportu taisyklių, informacinių ženklų, informacinių plakatų, schemų ir t. t.) apipavidalinima, išdèstyma, instaliavimą ir priežiūrą.

Pagrindiniai ES norminiai aktai, reglamentuojantys keleivių vežimo geležinkeliais kokybę, yra ES direktyvos ir Europos Parlamento ir Tarybos reglamentas. 2008 m. birželio 17 d. Europos Parlamento ir Tarybos direktyvos 2008/57/EB dèl geležinkelių sistemos sąveikos Bendrijoje tikslas - nustatyti reikalavimus, kurių turi būti laikomasi siekiant užtikrinti Bendrijos geležinkelių sistemos sąveiką, suderintą su Direktyvos 2004/49/EB nuostatomis. Šie reikalavimai yra susiję su šios sistemos dalių projektavimu, konstravimu, pradejjimu eksploatuoti, patobulinimu, atnaujinimu, naudojimu ir technine priežiūra, taip pat su personalo, kuris ją eksploatuoja ir techniškai prižiūri, profesine kvalifikacija ir sveikatos bei saugos salygomis. Šioje direktyvoje numatyti bendrieji saugos, patikimumo ir prieinamumo, sveikatos, aplinkosaugos ir techninio suderinamumo reikalavimai. Pateikti konkretūs reikalavimai kiekvienam posistemiui: infrastruktūrai, energetikai, kontrolès komandoms ir signalizacijai, riedmenims, techninei priežiūrai, traukinių eismo organizavimui ir valdymui, krovinių ir keleivių vežimo telematikos priemonèms. Viešai prieinama infrastruktūra turi būti suprojektuota ir išdėstyta taip, kad būtų apriboti žmonių saugai kylantys pavojai (stabilumas, priešgaisrinè sauga, prieinamumas, evakuacija, platformos ir kt.). Kontrolès komandų ir signalizacijos įrenginiai ir naudojamos procedūros turi sudaryti sąlygas pasiekti tokị traukinių važiavimo saugos lygi, kuris atitiktų tinklui nustatytus tikslus. Visa nauja infrastruktūra ir visi nauji riedmenys, pagaminti ar sukurti patvirtinus suderinamas kontrolès komandų ir signalizacijos sistemas, turi būti pritaikyti naudoti tose sistemose. Riedmenų ir transporto priemonių jungčių konstrukcija turi būti suprojektuota taip, kad ìvykus susidūrimui ar nuvažiavus nuo bejgiu būtų apsaugotos keleivių kupe ir mašinisto kabina. Kilus pavojui, itaisai turi sudaryti sąlygas keleiviams pranešti apie tai mašinistui, o palydovams - su juo susisiekti. İejimo durys turi turèti keleivių sauga garantuojančią atidarymo ir uždarymo sistemą. Turi būti irengti ir nurodyti avariniai išejejimai. Traukiniai turi būti aprūpinti keleiviu informavimo sistema, kad traukinio personalas turètų ryši su keleiviais. Riedmenų charakteristikos turi būti tokios, kad leistų jiems važiuoti visomis linijomis, kuriomis važiuoti jie numatyti, atsižvelgiant ị atitinkamas klimato sąlygas. Tinklo eksploatacijos taisyklių darna, mašinistų, traukinio personalo ir traukinių eismo valdymo darbuotojų kvalifikacija turi užtikrinti geležinkelių sistemos eksploatacini efektyvumą atsižvelgiant $i$ ịvairius tarptautinio ir vidaus vežimo reikalavimus. 
Europos Parlamento ir Tarybos reglamentu (EB) Nr. 1371/2007 dèl geležinkelių keleivių teisių ir pareigų nustatomos taisyklès dèl:

a) informacijos, kurią turi suteikti geležinkelio imonès, sutarčių dèl transporto sudarymu, bilietų išdavimu ir kompiuterizuotos geležinkelių transporto informacijos ir rezervavimo sistemos igyvendinimu;

b) geležinkelio įmonių atsakomybès ir jų draudimo įsipareigojimais dèl keleivių ir jų bagažo;

c) geležinkelio i̇monių įsipareigojimų keleiviams vèlavimo atveju;

d) geležinkeliais keliaujančių neigaliujų ir ribotos judèsenos asmenų apsaugos ir pagalbos jiems;

e) paslaugų kokybès standartų apibrèžimo ir stebėsenos, keleivių asmeniniam saugumui kylančių pavojų valdymo ir skundų tvarkymo;

f) bendrų vykdymo taisyklių.

Europos Parlamento ir Tarybos reglamento (EB) Nr. 1370/2007 dèl keleivinio geležinkelių ir kelių transporto viešujų paslaugų tikslas - nustatyti, kaip kompetentingos institucijos, laikydamosi Bendrijos teisès nuostatu, gali veikti viešojo keleivinio transporto srityje, siekdamos užtikrinti bendrus ekonominius interesus atitinkančių paslaugų teikimą, kad tų paslaugų būtų daugiau, jos būtų saugesnès, kokybiškesnès ir pigesnès nei jas teikiant iprastinèmis rinkos sąlygomis.

Apžvelgti pagrindiniai keleivių vežimo geležinkeliais kokybę Lietuvos Respublikoje (ES) reglamentuojantys dokumentai rodo, kad pagrindinis demesys skiriamas keleivių ir vežejų teisèms, pareigoms ir atsakomybei, darbuotojų elgesio principams bei taisyklëms, traukinių eismo organizavimo, tvarkymo ir saugumo principams.

\subsection{Geležinkelio infrastruktūros tyrimai}

Transporto sektoriaus plètimasis, ypač kelių transporto, turi daug reikšmès spūstims susidaryti, saugos padèčiai prastèti ir užterštumui didèti (Mačiulis et al. 2009). Svarbiausi geležinkelių plètros kriterijai - eismo saugumas, ekologiškumas, konkurencingumas, t. y. aukšta i klientą orientuota teikiamų paslaugų kokybė, jų ivvairovè. Vakarų Europoje po ilgų svarstymų tapo aišku, kad kontinento ekonomikos plètra neįmanoma be geležinkelių transporto, o geležinkelių egzistavimas neįmanomas be didelių greičių. Reikalavimai, keliami Europos geležinkelių infrastruktūrai, yra formuluojami remiantis geležinkelių transporto politikos ir strategijos gairèmis (Butkevičius, Jaržemskis 2000).

Geležinkelių pramonei veriasi tokios šalys, kaip Alžyras, Argentina, Persų ilankos šalys, Izraelis ir Indija. JAV, kurioje išplètotas automobilių ir oro transportas, taip pat peržiūrejjo savo transporto politiką ir diegia greituosius geležinkelius 
(Schwieterman, Scheidt 2007). Šiaurès Amerikoje padidejusios lèšos iš keleivių ir krovinių vežimo geležinkeliais yra investuojamos i naują infrastruktūrą (Dingler et al. 2009). Pietų Korejjos traukinys ekspresas įdiegé greitujų geležinkelių linijų paslaugas nuo $2004 \mathrm{~m}$. balandžio $1 \mathrm{~d}$. Šiuo metu jos turi dvi linijas, apimančias $661,1 \mathrm{~km}$, ir tose linijose traukiniai pasiekia $300 \mathrm{~km} / \mathrm{h}$ greitị. Pietu Korejjos traukinys ekspresas sumažino kelionès geležinkeliu laiką tarp pagrindinių miestų beveik per pusę (Suh, Yang 2005). $2005 \mathrm{~m}$. centrinès Japonijos geležinkelių bendrovè pasiekè naujų technologinių laimèjimų, kurie padejjo padidinti pajamas, gaunamas panaudojus superlaidžias magnetines sistemas. Pirmasis bandomasis važiavimas superlaidžiomis magnetinèmis sistemomis buvo atliktas $1998 \mathrm{~m}$. gegužès mènesị. Jo metu buvo pasiektas nuo $450 \mathrm{~km} / \mathrm{h}$ iki $500 \mathrm{~km} / \mathrm{h}$ greitis (Nakagawa, Matsuda 2005). Geležinkelių pramonès negali nedžiuginti Kinija, kurioje jau tiesiamas gigantiškas skubiujų geležinkelių tinklas. Bandymų metu greitojoje geležinkelio magistraleje Pekinas-Šanchajus Kinijoje pagamintas lokomotyvas CRH380A ir jo traukiamas keleivinis sąstatas $2010 \mathrm{~m}$. gruodžio $5 \mathrm{~d}$. pasieke $486 \mathrm{~km} / \mathrm{h}$ greiti. Naujoji greitujų traukinių magistrale Pekinas-Šanchajus turètų būti atidaryta 2012 metais. Rusijoje taip pat siekiama įdiegti greituosius traukinius. Šiuo metu modernizuotas geležinkelis Maskva-Sankt Peterburgas turi $250 \mathrm{~km} / \mathrm{h}$ projektini greiti, o ta pačia kryptimi ateityje ketinama nutiesti visiškai naują $300-350 \mathrm{~km} / \mathrm{h}$ greičio modernų geležinkelio ruožą. Siekiant padidinti traukinių eismo saugumą ir sumažinti eksploatacijos išlaidas Rusijos geležinkeliuose, priimami techniniai ir technologiniai sprendimai (Лысюк et al. 2003, Мирошниченко et al. 2008).

İžengus į naują geležinkelių amžių, esminis dalykas yra užtikrinti saugų geležinkelių infrastruktūros eksploatavimą, laikytis saugumo standartų reikalavimų (Rao, Tsai 2007). Eismo saugumui užtikrinti geležinkeliuose diegiamos kelio kontrolès, signalizacijos ir traukiniu valdymo, komunikacijos sistemos (Hamilton, Edwards \& Kelcey 2009), vertinama sąstatų ir kelio parametrų itaka traukinių eismo saugumui (Черкашин, Погорелов 2010). Nustatyta, kad reikšmingiausi iš nagrinètų nepalankių faktorių yra bėgių nelygumai ir traukinio išilginès jègos. Vertinant sąstato nuvažiavimo nuo bègių tikimybę, parenkami rodikliai, kriterijai ir kelio nelygumai (Жаров 2010), pateikiami pagrindiniai kai kuriu kelio ir sąstato parametrų itakos rato-bègio nusidèvejjimui tyrimo rezultatai ir analizé (Захаров, Ромен 2010a; Захаров et al. 2010b). Kuriami modeliai geležinkelio sankasos eksploatacinėms savybėms (po judančiu krūviu) vertinti, atliekama spektrinè grunto akceleracijos analizè (Ho et al. 2009). Vertinamas sankasos storis ir traukinio greitis (Huang et al. 2009a), atliekami i̇vairių tipų sąstatu, važiuojančių skirtingu greičiu, poveikio keliui skaičiavimai tiesiuose ruožuose ir kreivèse (Горбунов 2010), bėgių kelio geometrinių parametrų vertinimas panaudojant palydovines sistemas (Koc 2012). Sudarytas skaičiavimo algoritmas dinaminėms apkrovoms ịvertinti. Didžiausias nagrinejjamos geležinkelio bėgių dvimatès sistemos, veikiamos dinaminès žadinančios jègos, poslinkis buvo 
$22 \mathrm{~mm}$. Buvo nustatytas nežymus tampriai plastinès medžiagos netiesiškumas (Noorzaei et al. 2012). Traukinių avarijos, didelis vagonų krovumas ir geležinkelio infrastruktūros senejjimas patvirtina reikalingumą gerinti geležinkelio technines apžiūras. Geležinkelio kelio ir aširačių defektams aptikti yra naudojamos nuo $20 \mathrm{kHz}$ iki $1 \mathrm{MHz}$ ultragarso bangos ir bekontaktè techninè apžiūra. Kalifornijos universitete, San Diege, buvo atliktas ultragarso bangų sklidimo pusiau pralaidžiu geležinkelio kelio pagrindu teorinis tyrimas taikant baigtinių elementų metoda (Coccia et al. 2009). Tyrimo rezultatai yra nuo $75 \%$ iki $100 \%$ patikimumo. Atliekant kelio testą buvo ivertintos ir klimato sąlygos - lietus, véjas. Charakterizuojamas ir nagrinejjamas geležinkelio sandūrų užpildymas pažangiais epoksidiniais klijais (Peltier, Barkan 2009), pateikiamos užteršto geležinkelio balasto laboratorinès charakteristikos (Huang et al. 2009b), atliekami bėgių tepalų bandymai (Марков 2011). Išmatavus ratus ir bègius buvo nustatyta, kad esant tepalui rato antbriaunio ir bėgio, net naujo, šoninio paviršiaus nusidèvejjimas labai mažas. Japonijos geležinkelių technikos mokslinis institutas tobulina sistemas, galėsiančias nustatyti tikslią traukinio vieta, pavyzdžiui, tunelyje arba vagono kèbulo pakrypimą (Sasaki 2005). Šiaurès Amerikoje geležinkelio infrastruktūros našumui ir eksploatacinèms savybèms nustatyti naudojama modeliavimo programine iranga ir statistinès analizès metodai (White 2005). Didelè reikšmė yra skiriama šiuolaikinių technologijų pažangai, kurios turètų paskatinti mobilių belaidžių irenginių ir tinklų pritaikymą geležinkeliuose (Fitzmaurice 2005), nagrinejjamas geležinkelio linijų pralaidumas (Ramunas et al. 2011) ir patikimumo koeficientas (Ивницкий, Полякова 2011), pasiūlyta (Hе et al. 2011) dinaminio koeficiento nustatymo formulè, kuri gali suteikti inžinerini pagrindą projektuojant ir vertinant tiltus, esančius miesto geležinkelio sistemoje. Atliekamas eksperimentinis triukšmo ir virpesių vertinimas miesto geležinkelio pralankose (Anastasopoulos et al. 2009a; Bruni et al. 2009b), iešmų eksploatavimo laiko tyrimai ir jo didinimo prielaidos (Gailienè et al. 2008). Siūlomi nauji būdai, kaip vertinti geležinkelio juostos užimtumo pajègumo panaudojimą (Gašparík, Zitrický 2010) ir jo padidinimo priemonès (Lai, Barkan 2009). Kruopštus eksploatavimo išlaidu planavimas yra būtinas siekiant optimizuoti lěšas (Dell'Orco et al. 2008). Šiuolaikinių traukinių katastrofos patvirtina būtinybę tobulinti bėgių defektų nustatymo sistemas, kurios būtų daug efektyvesnès už naudojamas šiuo metu (Scalea et al. 2005). Kuriami modeliai, skirti geležinkelio bėgių lūžiams nustatyti ir traukinių katastrofų rizikai kontroliuoti (Zhao et al. 2007). Atliekami bėgių kelio bandymai naudojant sunkius krūvius (Li, Bilow 2008). Taikant baigtinių elementų metoda atliekamas traukinio sukelto grunto virpejjimo modeliavimas ir analizè (Hall 2003), empirinių modelių patvirtinimas (With et al. 2006), vejjo poveikio dinaminè analizè traukiniui važiuojant tiltu (Xia 2008), trimačio erdvinio tiltas-skubusis traukinys (bègis-aširatis) sąveikos modelio dinaminè analizè (Dinh et al. 2009). Didelę reikšmę eismo saugumui 
privalo skirti tos šalys, kuriose ypatingos klimato sąlygos. Pavyzdžiui, Šiaurès Vakaru Prancūzijoje daugelio regionų gruntas yra sudarytas iš durpių. Dirvos paviršius netoli geležinkelio kelio turi būti aukšto pajègumo, kad saugiai važiuotų skubieji traukiniai, tokie kaip T. G. V. (angl. Train Grand Vites). Tam atliekamas grunto vibracijos nuo geležinkelio sąstato ivertinimas ir prognozès (Picoux, Houedec 2005). Analizuojamas dinaminis spaudimas, sukeltas pravažiuojančio traukinio, amžinojo įšalo geležinkelio sankasoje Qinghai-Tibet (Zhu et al. 2011). Taikoma programų visuma tinkamiausiam bėgių kelio saugumo palaikymui (Vale et al. 2012), sudaromi geležinkelio kelio, balasto priežiūros valdymo modeliai (Burrow et al. 2009; Sevi, Ge 2012). Kylant naftos, elektros, dujų kainoms yra būtina ieškoti būduc, kaip gyventi taupiau. Investuojama i technines, organizacines, technologines priemones, tobulinamas valdymas, energetiniai resursai, atliekami makroekonominiai transporto infrastruktūros plètojimo vertinimai (Мачерет et al. 2010).

Lietuvoje dar nẻra greitujų geležinkelių magistralès, tačiau Lietuvos teritoriją kerta du tarptautiniai transporto koridoriai I ir IX, turintys ypatingą reikšmę visai Europos transporto sistemai. Siekiant padidinti geležinkelių transporto sistemos konkurencingumą tarptautineje ir vietineje transporto paslaugu rinkoje, 2010-2012 m. ir toliau bus vykdoma geležinkelio linijų rekonstrukcija. Atnaujinus infrastruktūrą keleivinių traukinių greitis atskiruose ruožuose padidès iki $160 \mathrm{~km} / \mathrm{h}$. Transporto specialistai teigia, jog yra dalyku, kurie atbaido potencialius keleivius iš užsienio ir Lietuvos naudotis geležinkelių transportu. Keliauti iš Lietuvos i Vakarų Europą arba iš Europos pasiekti Lietuvą šiandien yra išties nepatogu. Reikia daug ryžto ir kantrybès, kad netgi iš netolimos valstybès pasiektum Vilnių traukiniu. Europos Komisijos atstovybès Lietuvoje vadovas Kęstutis Sadauskas, pristatydamas Baltijos jūros regiono valstybių strategija, nepraleido progos paironizuoti, jog šiandien važiuoti nuo Talino iki Varšuvos (per Lietuva) užtrunka 36 valandas, t. y. traukinys rieda maždaug tokiu greičiu, kaip bègo Pekino olimpiados čempionas. „Kuris dalykiškas žmogus rinksis transporto priemonę, kurią galètų aplenkti bėgantis žmogus?" - retoriškai klausé prelegentas (http://www.alfa.lt/straipsnis/10280230/?Ar.Lietuvoje....=2009-07-04 ...). Dèl šios priežasties geležinkelių transportas nèra patrauklus nei užsienio, nei Lietuvos keliautojams. Lietuvai ịstojus į ES, labai svarbu sudaryti sąlygas tiek Lietuvos, tiek kitų ES šalių gyventojams patogiai keliauti traukiniais. Geležinkelio efektyvumui ES šalyse pagerinti būtina ịvertinti esamas kliūtis (Walker et al. 2008). Lietuvai tikslinga atnaujinti tiesiogini susisiekimą geležinkeliais su Lenkija. Tai leistu šalies gyventojams traukiniais susisiekti su Europos šalimis (Butkevičius 2007). Daug vilčiu yra siejama su „Rail Baltica“ projektu. 


\subsection{Geležinkelio riedmenų tyrimai}

Japonijos greituosiuose traukiniuose „Shinkansen“( bullet train - traukinys kulka), kurie pirmą kartą buvo pristatyti pasauliui 1964 m., taikomos naujoviškos lengvosios elektroninès technologijos (Hagiwara et al. 2007). Nagrinejama vagono (Lei, Zhang 2011) ir struktūrinè dinamika geležinkelių transporto priemonių sistemose (Stribersky et al. 2000). Italijoje yra labai sudètingi keliai ir geležinkeliai, kadangi reikia važiuoti daugybe tunelių. Siuo metu eksploatuojamų geležinkelių linijų ilgis Italijoje yra $16000 \mathrm{~km}$. Jos turi 2000 tunelių, kurių bendras ilgis $1400 \mathrm{~km}$, todèl labai svarbu užtikrinti traukiniuose priešgaisrinę sauga. Atlikus traukinio, važiuojančio tuneliu gaisro atveju, rizikos analizę, priimtos išvados: gaisro modelio kreivès lygis, pavaizduotas Italijos standartuose, yra labai sumažintas, t. y. mažesnis, negu kreivès bandymų metu, esant dideliam traukinio užimtumui. Reikia tikslaus ir aiškaus evakuacijos proceso. Keleivių išsigelbejjimo tikimybei didelę reikšmę turi jų sąmoningumas ir iki minimumo sumažintas reakcijos laikas, todèl labai svarbūs yra gaisro aptikimo ir pavojaus signalizacijos prietaisai, irengti keleiviniame traukinio vagone (Martinelli et al. 2008).

Rusija ketina atnaujinti traukos riedmenų parką ir per dvidešimt metų isigyti 20000 lokomotyvų.

Transporto sistemos turi būti išplètotos ir standartizuotos, turi būti efektyvesnè transporto sektoriaus priežiūra ir kartu sumažinta aplinkos ir triukšmo tarša (traukos riedmenyse esančių ivvairių triukšmo šaltinių sukuriamas akustinis triukšmas) arba jos išvengta (Akgüngör, Demirel 2008; Bazaras 2006; Paslawski 2009; Tanczos, Torok 2007). Pastaruoju metu transporto problemos sprendžiamos pasitelkiant mokslinius tyrimus ir jais gautas išvadas bei siūlymus (Gould, Niemeier 2009). Lyginamos greitaeigès transportavimo sistemos, pateikiama jų vertės stochastinio vertinimo metodika (Schach, Naumann 2007), nagrinejjami geležinkelio traukos riedmenų elektrodinaminio stabdymo teoriniai ir techniniai aspektai, kurie ypač aktualūs greitaeigiame geležinkelio transporte (Liudvinavičius, Lingaitis 2007), analizuojama esama šilumvežių kokybės vertinimo metodika (Juršènas, Vaičiūnas 2007) ir traukinių katastrofų priežasčių bei dažnumo priklausomybė nuo traukinio ilgio (Schafer II, Barkan 2008). Atlikta geležinkelio riedmenų automatinès sankabos ilgaamžiškumo (Daunys et al. 2009) ir ratų riedejjimo paviršiaus atkūrimo metodų analizè (Воробъев et al. 2011).

Lietuvoje ir kai kuriose kitose šalyse geležinkelių transportas nèra patraukliausia transporto rūšis: transporto priemonès dar nèra labai patrauklios keleiviui dèl nepakankamo kelionès patogumo lygio, palyginti nedidelio traukinių greičio, prastų kelio ir riedmenų dinaminių charakteristikų (Bureika 2008a; Dailydka et al. 2008; Keršys, Bazaras 2001; Lata 2008; Magyla 2002). Riedmenims senstant didèja eksploatavimo sąnaudos (Vaičiūnas, Lingaitis 2008). Analizuojamos serijinių prekinių šilumvežių eksploatavimo sąnaudos, pateikiami būdai joms ma- 
žinti (Bureika 2011), atliekami geležinkelio riedmenu gendamumo tyrimai (Gelumbickas, Vaičiūnas 2011), atkuriamos rato ratlankio metalo fizinès ir mechaninès savybès (Bazaras, Somov 2011), analizuojamos jègos, veikiančios aširati (Bazaras et al. 2008), o lokomotyvo traukai vertinti sudaromi stochastiniai modeliai (Елисеев 2010). Taip pat svarstomos greitujų keleivinių traukinių eismo problemos ir perspektyvos (Sakalauskas, Rezgaitis 2000).

\subsection{Keleivių vežimo geležinkeliais proceso tyrimai}

Pastaruoju metu transporto problemos sprendžiamos pasitelkiant mokslinius tyrimus ir jais gautas išvadas bei siūlymus. Gvildenama ES šalių skirtingų geležinkelio sistemų sąveikos problema (Bureika, Mikaliūnas 2008b), taikomas miesto geležinkelių sistemų priešprojektinių išlaidų apskaičiavimo metodas, pagristas parametriniu modeliavimu (Sonmez, Ontepeli 2009) ir sukurtas miesto geležinkelių darbo modelis, kuris yra vertinga priemonè sudètingos vežimų geležinkeliais sistemos darbui (Koutsopoulos, Wang 2007), gerinama geležinkelių eismo saugos (Strang et al. 2007) ir priešgaisrinès saugos būklè (Щеглов et al. 2007).

Spartèjanti greitujų geležinkelio linijų tiesyba Europoje ižiebẻ rimtas diskusijas apie galimybę šiose linijose įdiegti bimodalini susisiekimą (Guirao et al. 2005). Europos geležinkeliams taikomos avialinijų mažų kainų strategijos (Sauter-Servaes, Nash 2007), geležinkelio poreikis didinamas gerinant multimodalinę informaciją ir bilietu pirkimą, pavyzdžiui, naktinių traukinių išvykimas derinamas su lèktuvų skrydžiais (Sauter-Servaes, Nash 2009). Pasiūlyta kainų nustatymo metodika ịvairiarūšiams geležinkelio tinklams naudoti (Calvo, Oña 2005; Calvo et al. 2007a), atliekama Europos skubiụjų traukinių linijų eksploatavimo išlaidų analizè (López-Pita et al. 2008), vertinamas didžiujų transporto projektų tinkamumas (Nash et al. 2007), vèlavimo poveikis keleivinių traukinių aptarnavimui (Preston et al. 2009). Kinijoje sparčiai plètojamos geležinkelio informacinèmis ir elektroninių ryšių technologijomis grindžiamos sistemos (RITS) (Zhuo, Li-min 2011) ir keleivinis transportas: stengiamasi mažinti kelionių kainą ir trumpinti jų laika, gerinti komfortą ir eismo saugumą (Si et al. 2009). Pajamų valdymo sistema plačiai naudojama ne tik JAV, Vakarų Europos šalyse, bet ir Rusijoje. Pateikiami pasiūlymai tarifams tobulinti, siekiant padidinti priemiestinių keleivinių vežimų efektyvumą (Толкачева, Мирошниченко 2007). Tarptautinio susisiekimo sektoriuje nagrinejjami traukiniuose teikiamų paslaugų gerinimo, didesnio patogumo suteikimo vagonuose, geležinkelio stotyse ir kt. uždaviniai (Шубин 2006). Eksploatuojant tolimojo susisiekimo keleivinius traukinius ir naudojant keleiviniam susisiekimui skirtus modelius, pajamos padidejo vidutiniškai 10-12 \% (Мирошниченко et al. 2010). Taigi, geležinkelių 
transportas tampa lyderiu ir stimuliatoriumi novatoriško ekonominio plètojimo, kurio pagrindas yra savo veiklos intensyvumo ir produktyvumo suderinimas su naujų tipu geležinkelio linijų sukūrimu ir plètra (skubiajam keleiviniam ir sunkiasvoriam krovininiam susisiekimui) (Лапидус, Мачерет 2011). Šiandien Europoje ir Japonijoje yra didelis veikiantis greituju geležinkelių tinklas, tačiau Japonijoje oro transportas konkuruoja su greitaisiais geležinkeliais, o Europoje papildo vienas kitą (Clever, Hansen 2008). Svarstoma traukinių kooperacijos galimybė daugiafunkcèje tarptautinèje geležinkelių transporto sferoje - intermodalini tinkla, apimanti 11 Skandinavijos šalių, pratęsti iki Graikijos per Bulgariją Čekija, Vengrija, Lenkija, Rumuniją ir Slovakiją (Kuo et al. 2008). Europos geležinkeliu transporto valdymo sistemoms (ERTMS) plètoti reikalingi atitinkami modeliavimo metodai (Jabri et al. 2010). Kad būtų pagerinti techniniai ir ekonominiai keleivių vežimo rodikliai, būtina igyvendinti keleivių srautų prognozavimo, regresinès analizès metodus panaudojant automatinę valdymo sistemą „Ekspress“. Taikant šiuos metodus galima planuoti keleivių vežimų ir sąstatų apimti. Planavimo efektyvumas pasireiškia tuo, kad 10-15\% sumažeja tuščių vietų rida traukiniuose, padidèja keleivių aptarnavimo kokybė ir sumažèja pajamų sąnaudos dèl laiku atlikto papildomų traukinių suformavimo (Макарова et al. 2011). Norint pritraukti kuo daugiau keleivių, būtina gerinti vežimo paslaugas: privaloma ne tik turèti kokybiškus riedmenis, bet ir puikų personalą, todèl darbuotojų teorines ir praktines žinių potencialo problemas jau keletą dešimtmečių tiria ivvairių sričių mokslininkai, o geležinkelių industrijoje diegiamos komandos išteklių valdymo mokymo programos (Morgan et al. 2007). Transporto infrastruktūros statybos ir priežiūros darbai yra rizikingi darbininkams. Jungtinèje Karalysteje saugumo problema yra pripažinta vyriausybės institucijų ir universitetų. Esant meistriškumo stokai, vyresnio amžiaus (sumažèjus darbingumui) darbininkams geriau atsistatydinti arba pakeisti darbą. Darbininkų iš kitų šalių antplūdis taip pat sukelia nesusikalbejjimo, efektyvaus informacijos perdavimo ir mokymo problemą. Rizikai nustatyti yra naudojamos darbininkų žinios ir patirtis (Campbell et al. 2007). Apie keleivių vežimą, kaip socialinę paslaugą ir su juo susijusias problemas, kalbama daug, o ypač pastaraisiais - krizès metais. Keleivių vežimai nèra pelningi, todèl būtina taupyti. Sèkmingai geležinkelių veiklai svarbus efektyvus geležinkelio terminalų funkcionavimas (Adamko, Klima 2008; Baublys 2009; Dirnberger, Barkan 2007), traukos priemoniu parametrų optimizavimas (Jonaitis 2006), nuostolių dèl traukinių vèlavimų bei papildomų energijos sąnaudų minimalizavimas (Mišauskaitè, Bagdonas 2006), reikiamo riedmenų sąstato skaičiaus planavimas vežimu geležinkeliais sektoriuje (Jonaitis 2007; Dailydka 2010), keleivių vežimo savikainos mažinimas (Ziari et al 2007), paskatinimai. Pavyzdžiui, Švedijoje paskatų rezultatas buvo toks, kad traukinių užlaikymas sumažèjo apie $10 \%$, o techninių klaidų skaičius - apie $20 \%$ (Stenbeck 2008). Teisingiems sprendimams priimti technologijos ir valdymo srityse, 
statybos automatizavimo procesuose, prioritetiniuose geležinkeliu projektuose ir kt. yra naudojami ekspertiniai vertinimai (Česnauskis 2007; Zavadskas et al. 2005; Wu et al. 2008; Abdelrahman et al. 2008; Chua, Li 2000; Liu et al. 2009; Brauers et al. 2008; Малъцев, Захаренков 2007), daugiakriterio vertinimo metodai (Ginevičius et al. 2004; Žvirblis, Zinkevičiūtè 2008; Sivilevičius et al. 2008; Sivilevičius 2001; Sivilevičius 2002), sprendimų paramos sistemų Topsis ir Saw (Jakimavičius, Burinskienè 2007; Tamošaitienè 2009), lošimu teorijos (Wang et al. 2007) ir AHP (Skibniewski et al. 1992; Ginevičius, Podvezko 2008; Liu et al. 2008; Lai et al. 2008; Pan 2008; Podvezko 2009; Ustinovichius et al. 2007; Vainiunas et al. 2009; Cheng et al. 2012) metodai, taikomos rangu procedūros, paremtos statistinių hipotezių tikrinimu (Weed et al. 2007). Daugiakriteriai sprendimu priemimo metodai taip pat taikomi statybos projektų rizikai vertinti (Zavadskas et al. 2010), gyvenamosios aplinkos atnaujinimo projektams (Tupènaitè et al. 2010), statybos sutartims (Podvezko et al. 2010), kuriant statybų žinių valdymo sistemą (Lin et al. 2011), gręžinių ịrengimo metodui parinkti (Lashgari et al. 2011), suteikiant prioritetus savivaldybiu statybos projektams (Aghdaie et al. 2012). Šie metodai sèkmingai taikomi transporto sistemos valdymo centro veiklai modeliuoti (Tica et al. 2011), pavojingujų krovinių transportavimo rizikai vertinti (Dzemydiené, Dzindzalieta 2010). Sprendimų priemimas pagristas alternatyvomis su keliais atributais: apklausa ir integruotu metodu (MacCrimmon 1968), kompromisų analize (MacCrimmon, Wehrung 1977).

Keleivių vežimai geležinkelių transportu už priimtiną kainą valstybei dažniausiai yra nuostolingi. Todèl vežant keleivius svarbu išvengti nuostolių. Šiam procesui optimizuoti taikomi ịvairūs skaičiavimai (Lingaitienè, Lingaitis 2006). Normuojamas šiluminès energijos panaudojimas geležinkelio įmonès skalbyklose, dezinfekavimo kamerose, cheminiam darbo drabužių valymui (Финиченко 2011).

Norint pritraukti kuo daugiau keleivių, būtina gerinti vežimo paslaugas, t. y. didinti vežimo geležinkeliais patrauklumą. Tam tikslui nustatomi keleivių poreikiai, vežimo kokybès ịvertinimo ir gerinimo būdai (Маскелюнайте, Сивилявичюс 2008). Atliekamos keleivių anketinès apklausos ir nustatomi kiekybiniai rodiklių reikšmingumai (Maskeliūnaitè et al. 2009a; Маскелюнайте, Сивилявичюс 2009c; Sivilevičius, Maskeliūnaitè 2010; Maskeliunaite, Sivilevicius 2011; Пастухов 2008a; 2008b; Огинская, Толкачева 2006; Мирошниченко, Пастухов 2006), siūlomas žinių potencialo vertinimo modelis, adaptuotas transporto sektoriui (Morkvėnas et al. 2008). Nagrinejjamas Lietuvos istojimo i ES poveikis šalies transporto sistemai ir transporto sistemos plètra (Butkevičius 2008), identifikuojamos keleivių vežimo šalies geležinkelių transportu problemos (Butkevičius 2009), ieškoma kitų novatoriškų būdų keleivių vežimo kokybei vertinti ir gerinti. Apklausos plačiai taikomos atliekant sociali- 
nius tyrimus, projektuojant transporto sistema, renkant reikiamą informaciją. Pavyzdžiui, Jungtinėse Amerikos Valstijose buvo atlikta anketinè apklausa dèl krovinių ir keleivių geležinkeliais koridoriaus išsaugojimo (Simpson 2007).

\subsection{Pirmojo skyriaus išvados}

1. Apžvelgus geležinkelio infrastruktūros, riedmenų ir keleivių vežimo geležinkeliais proceso tyrinejimo aspektus, galima teigti, kad norint padaryti keleivini geležinkelių transportą efektyvų, visu pirma būtina kreipti dèmesi i i šiuos veiksnius: traukinio elementų ir geležinkelio kelio techninès būklès gerinimą, vežimo patrauklumo ir eismo saugumo didinima, rinkos kainų taikymą vežimui.

2. Mokslinių darbų analizè rodo, kad pagrindinis dèmesys skiriamas greitujų geležinkelio linijų steigimui, eismo saugumo užtikrinimui, riedmenų dinamikai. Mažai darbų kuriuose nagrinejjami TKVGKK, ieškoma kitų novatoriškų būdų kelionès traukiniu kokybei (KTK) vertinti ir gerinti. Norint pritraukti kuo daugiau keleivių būtina rengti nuolatines keleivių apklausas, žinoti keleivių norus bei pageidavimus, atskirų maršrutų vežimų kokybę, i juos atsižvelgti organizuojant kelionès traukiniu procesa. 


\section{Keleivių vežimo geležinkeliais kokybès kriterijai ir proceso modeliai}

Skyriuje atlikta LG veiklos ir keleivių vežimo rodiklių apžvalga, kelionès tarptautiniu traukiniu kokybès kriteriju pagrindimas ir sisteminimas. Pateiktas autorès sudarytas TKVGK kompleksinis adityvinis vertinimo modelis, kurị taikant galima nustatyti faktiškają vežimo kokybę LG tarptautiniais maršrutais. Atskirų maršrutų traukinių sąstatai yra suformuoti iš skirtingos techninès būklès, nevienodos konstrukcijos vagonų, kuriuos aptarnauja skirtingą išsilavinimą, darbo patirti turintys darbuotojai. Faktiškają vežimų kokybę bet kuriame traukinyje galima nustatyti tik apytiksliai, intuityviai. Keleivių vežimo kokybei ivertinti traukinyje (maršrute) duomenų stoka paskatino kurti kiekybini metodą ir rodiklį $K$, leidžiančius objektyviai vienu skaičiumi išreikšti keleivių vežimo kokybę tarptautiniu traukiniu (Sivilevičius et al. 2012).

\subsection{AB „Lietuvos geležinkeliai“ veiklos ir keleivių vežimo rodiklių apžvalga}

Transporto veikloje keleivių vežimai užima ypatingą vietą. Jie turi svarbią socialinę ekonominę reikšmę visuomenès gyvenime ir užtikrina vieną iš svarbiausių valstybès uždavinių - judejjimo laisvę (Белов et al. 2001). Svarbiausi 
LG veiklos prioritetai - eismo saugumas, ekologiškumas, taršos prevencija, energetinių resursų taupymas, konkurencingumas, aukšta i klientą orientuota teikiamu paslaugu kokybè. Siekiant igyvendinti šiuos prioritetus ir užtikrinti sèkmingą Lietuvos geležinkelių transporto integravimąsi i tarptautines transporto sistemas, modernizuojama geležinkelių infrastruktūra, atnaujinamas riedmenų parkas, diegiamos pažangios informacinès vežimo technologijos ir intelektinès transporto sistemos.

Visuomenès išlaidos, skirtos geležinkelių transportui, susideda iš geležinkelio kelių (infrastruktūros) priežiūrai bei plètrai, riedmenų parko atnaujinimui (turimų riedmenų modernizavimui ir pirkimui naujų) (2.1 pav.) bei eksploatacijai skiriamo finansavimo, taip pat iš geležinkelių transporto naudotojų (keleivių) patiriamų išlaidų. Skirtingi keleivių vežimo paslaugos kokybès lygiai reikalauja nevienodų išlaidų.

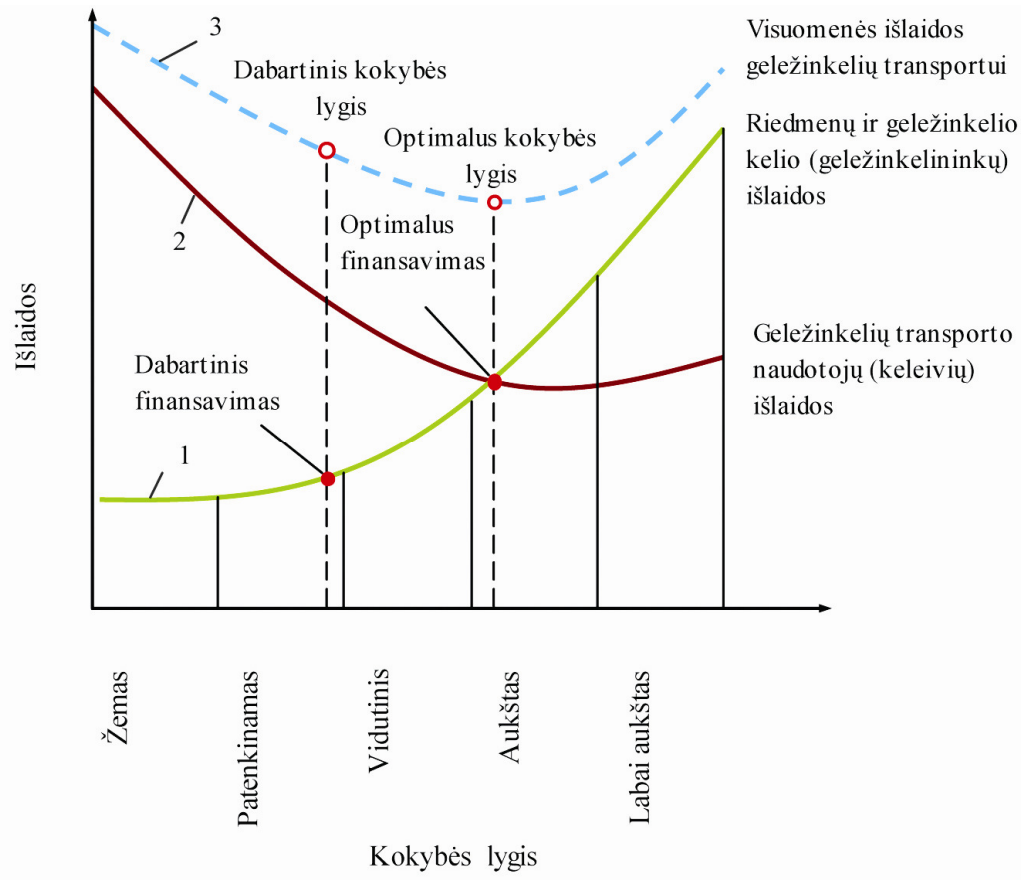

2.1 pav. Geležinkelių transportu vežant keleivius išlaidų priklausomybès nuo kokybès lygio modelis: 1 - riedmenų ir geležinkelio kelio (geležinkelininkų) išlaidos;

2 - geležinkelių transporto naudotojų (keleiviu) išlaidos; 3 - visuomenès (suminès) išlaidos

Fig. 2.1. The model of the dependence of the costs of passenger transportation by railway on the level of the trip quality: 1 - expenses of the train and railway staff;

2 - railway passengers' expenses; 3 - (total) social expenses 
Geležinkelio keliu priežiūros ir plètros išlaidas sudaro lèšos, panaudotos jiems tiesti, remontuoti ir prižiūrèti. Geležinkelininkų išlaidų didelę dali sudaro riedmenų atnaujinimo, issigijimo, remonto ir eksploatacijos (degalai, elektros energija, atsarginès dalys, tepalai, darbuotojų atlyginimas ir pan.) išlaidos.

Geležinkelių transporto naudotojų išlaidas sudaro kelionès gaišaties nuostoliai, kelionès (bilietų) kaina, nuostoliai dèl eismo įvykių bei aplinkos taršos, nepakankamo kelionès patogumo.

Iki tam tikro lygio didinant geležinkelininkų išlaidas mažèja keleivių ir visuomenès (suminès) išlaidos. Keleivių išlaidos mažèja, nes dèl didesnio važiavimo greičio sutrumpejja kelionès laikas, taip pat sumažèja tikimybè patekti i eismo ỉvyki (išvengiama gydymo ir draudimo išlaidų). Kai geležinkelininkų ir keleivių išlaidų kitimo kreivès susikerta, turime mažiausias visuomenès išlaidas, t. y. optimalų kokybės lygi. Didejjant kokybès lygiui, geležinkelių transporto naudotoju išlaidos taip pat dideja - brangsta bilietai, paslaugos. Neinvestuojant pakankamai lešsc $\mathfrak{i}$ infrastruktūrą ir riedmenis kelionés traukiniu kokybe būna žema arba transporto rūšis - nepatraukli.

Svarbu identifikuoti keleivių vežimo šalies geležinkelių transportu problemas - keleivių srautų mažejjimą, vežimo savikainos didejjimą, nepakankamą nuostolingo vežimo finansavimą. AB „Lietuvos geležinkeliai“ vyksta teigiami pokyčiai. Per pastaruosius 10 metu investavusi apie 3,6 mlrd. Lt bendrové eksploatuoja modernų prekinių lokomotyvų parka, pagrindinèse geležinkelio linijose ir stotyse idiegtos šiuolaikiškos signalizacijos, telekomunikacijų, riedmenų kontrolès sistemos, atnaujinti geležinkelių statiniai, keleivių rūmai, issigyjami nauji ekonomiški keleiviniai traukiniai. $2010 \mathrm{~m}$. gegužę pradèti projekto „Rail Baltica“ darbai. „Rail Baltica“ - geležinkelio linija, sujungsianti Varšuva, Kauna, Ryga, Talina, Helsinki ir leisianti plètoti krovinių bei keleivių susisiekimą tarp Baltijos valstybių ir Europos šalių. Lietuvos Respublikoje „Rail Baltica“ pripažintas valstybei svarbiu ekonominiu projektu.

2011 m. AB „Lietuvos geležinkeliai“ vietiniais maršrutais kursavo 187 traukiniai, o tarptautiniais -4 bendrovès formavimo traukiniai. I Lietuvą ar tranzitu per Lietuvos teritoriją važiavo 20 kitų šalių geležinkelių traukinių.

Keleivių vežimo dinamika 2007-2011 m. pavaizduota 2.2 paveiksle. $2011 \mathrm{~m}$. traukiniais vežta $4,7 \mathrm{mln}$. keleivių, iš jų:

- vietinio susisiekimo traukiniais - 3,8 mln. keleivių;

- tarptautinio susisiekimo traukiniais $-0,9 \mathrm{mln}$. keleivių.

$2011 \mathrm{~m}$. keleivių vežta $6,7 \%$ daugiau nei $2010 \mathrm{~m}$.

Taigi, keleivių vežimo mastai LG stabilizuojasi (2.1 lentelè) - bendrovè $2011 \mathrm{~m}$. vežè apie 4,7 mln. keleiviu, t. y. 0,3 mln. daugiau nei $2010 \mathrm{~m}$.

Keleivių vežimo pajamos, palyginti su 2010 m., padidèjo $10 \%$ (2.3 pav.). 


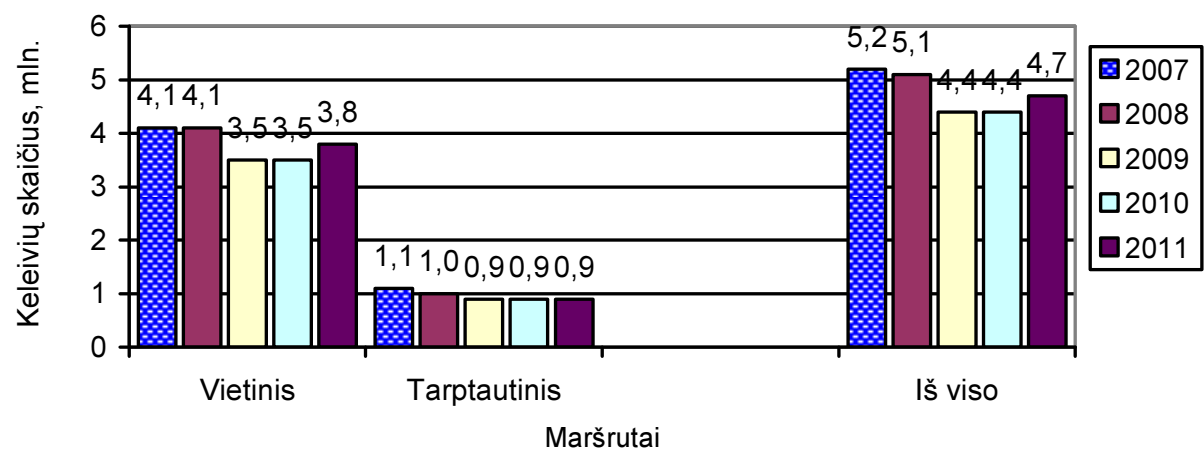

2.2 pav. Keleivių vežimo dinamika 2007-2011 m. (mln. keleivių)

Fig. 2.2. The dynamics of passenger flows (mil), 2007-2011

2.1 lentelè. Keleivių vežimo rodikliai 2008-2011 m.

Table 2.1. Passenger flows in 2008-2011

\begin{tabular}{|l|c|c|c|c|}
\hline \multirow{2}{*}{\multicolumn{1}{|c|}{ Rodiklis }} & \multicolumn{4}{c|}{ Metai } \\
\cline { 2 - 5 } & 2008 & 2009 & 2010 & 2011 \\
\hline Iš viso vežta keleiviü, mln. & 5,1 & 4,4 & 4,4 & 4,7 \\
\hline Keleivių apyvarta, mln. keleivio km & 397,5 & 356,9 & 373,1 & 389,1 \\
\hline Vidutinis vieno keleivio vežimo nuostolis, km & 78,5 & 81,6 & 85,5 & 83,6 \\
\hline Vidutinis vienam šalies gyventojui tenkantis kelionių skaičius & 2 & 1 & 1 & 1 \\
\hline
\end{tabular}

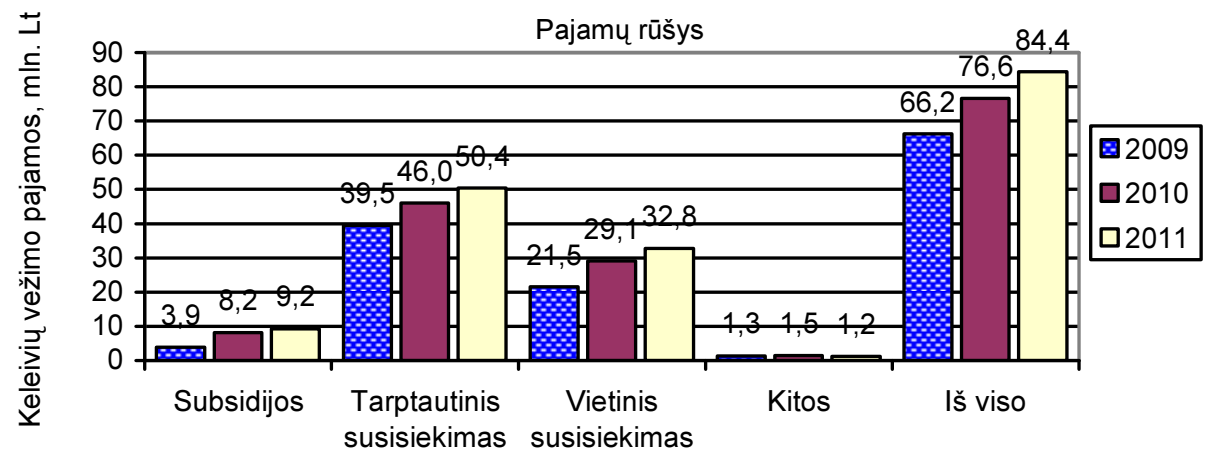

2.3 pav. Keleivių vežimo pajamos 2009-2011 m. (mln. Lt)

Fig. 2.3. The income brought by passenger transportation in 2009-2011 (million Lt)

Keleivių vežimo turtui atnaujinti ir modernizuoti $2010 \mathrm{~m}$. panaudota $83,9 \mathrm{mln}$. Lt. $2010 \mathrm{~m}$. issigyti ir pradèti eksploatuoti 2 dviaukščiai elektriniai 
traukiniai (iš viso nuo 2008 iki $2010 \mathrm{~m}$. bendrove isigijo 4 tokius traukinius), isigytos ir eksploatuojamos 3 vieno vagono automotrisès (iš viso nuo 2008 iki $2010 \mathrm{~m}$. bendrove įsigijo 7 tokias automotrises) (Lietuvos geležinkeliai. Metiné ataskaita 2010). $2011 \mathrm{~m}$. bendrove isigijo ir pradejo eksploatuoti 5 automotrises $620 \mathrm{M}$, tais pačiais metais pagamintas PESA Bydgošč gamykloje (Lenkija) (Lietuvos geležinkeliai. Metinè ataskaita 2011).

\subsection{Kelionès tarptautiniu traukiniu kokybès kriteriju pagrindimas ir sisteminimas}

Kokybę sunku tiesiogiai išreikšti bei išmatuoti kokiu nors vienu kriterijumi. Ją galima apibūdinti tik tam tikra kriterijų sistema (Zavadskas et al. 2001). Šiame skyriuje atliktas kelionès tarptautiniu traukiniu kokybès kriteriju pagrindimas ir sisteminimas.

\subsubsection{Kriterijai, susieti su traukinio elementais ir geležinkelio kelio technine būkle}

Formuluojami ir pagrindžiami kriterijai, susieti su traukinio elementais ir geležinkelio kelio technine būkle.

Geležinkelio bėgiu (kelio) lygumas. Bègis yra svarbiausias ir brangiausias geležinkelio kelio elementas. Nuo jo būklès priklauso patikimas, nepertraukiamas ir saugus traukinių eismas. Geležinkelio riedmenys juda bègiais, ant kurių būna nelygumų. Dèl to atsiradę geležinkelio riedmenų virpesiai gali būti nepageidaujami, ypač jeigu nelygumai dažnai pasitaiko kelyje ir judama dideliu greičiu. Dèl vibracijos sutrinka kai kurių žmogaus organų ir sistemų veikla. Dažniausiai pažeidžiama nervų, širdies ir kraujagyslių, kaulų ir raumenų sistema. Žmogaus jautrumas vibracijai priklauso nuo individualių organizmo savybių.

Traukinio greitis (važiavimo trukmè). Šiuo metu Lietuvoje didžiausias leidžiamasis keleivinių traukinių greitis kai kuriuose kelio ruožuose yra $120 \mathrm{~km} / \mathrm{h}$. Tam, kad traukiniai važiuotų greičiau, būtina gerinti geležinkelio kelio techninę būklę ir eismo valdymo sistemą, rengti kelius, pritaikytus tik greitajam eismui. Traukinio greitis ir važiavimo trukmè yra susiję.

Išorinè vagono būklè (švara, pažaidos). Estetinis vagono vaizdas yra svarbu, nes ji pirmiausia pamato keleivis, atejęs i peroną. Nešvarus, turintis kèbulo deformacijos defektų vagonas gali blogai nuteikti keleivị. Nemalonu stebèti vaizdą už lango per neplautus langų stiklus.

Triukšmą mažinančios priemonès (priemonès su garso izoliacija). Triukšmo žalą sveikatai žmonija žinojo jau senovejje. Triukšmas pagrịstai yra laikomas viena svarbiausių ekologinių problemų. Jis trukdo darbui, poilsiui, neigiamai veikia 
žmogaus sveikatą: gali išsivystyti klausos, nervu̧, širdies ir kraujagyslių, virškinamojo trakto ligos. Triukšmo žalingos įtakos sveikatai mažinimui taikomos priemonès turi būti skirtos triukšmo lygiui mažinti. Didejjant traukinių greičiui, būtina tobulinti vagonų technines konstrukcijas (irengiant slankiąsias grindis, amortizatorius ir kt.), garsą izoliuojančias ir sugeriančias medžiagas, gerinti įrenginių techninę priežiūrą ir remonta, taip pat gerinti geležinkelio kelio kokybę.

Vagono interjeras. Interjeras - tai pastato ar patalpos vidus; meniškai suformuota ir apipavidalinta vidaus erdve ir jos įrenginiai. Vagono išorès išvaizda ir interjeras kuriami laikantis techninès estetikos reikalavimų, kurie grindžiami konstrukcijų geometrinių formų išraiškingumu, racionalumu ir patogumu. Šiuolaikiniai keleiviniai vagonai turi būti pakankamai ištaigingi. Jų ištaigingumas vertinamas lyginant su kompleksu techninių sprendimų, kurie leidžia atitikti techninės estetikos, kèbulo atitvarų šiluminès izoliacijos, oro kondicionavimo, karšto ir šalto vandens tiekimo, keleivinių, buitinių ir tarnybinių patalpų apšvietimo, leidžiamo triukšmo lygio vagone, taip pat judèjimo tolygumo reikalavimus (Bazaras, Dundulis 1996).

Védinimo, oro kondicionavimo, apšvietimo irangos veikimas. Vėdinimo, oro kondicionavimo, šildymo sistemos padeda bet kuriuo metu laiku palaikyti reikiamą vagono temperatūrą. Kokybiškas oras yra svarbus veiksnys. Oro judèjimas patalpose yra būtinas, kitaip kaupiasi anglies dioksidas, drègmè ir teršalai, kuriuos skleidžia sintetinès bei cheminès medžiagos, i̇vairūs dažai, lakai, grindų dangos. Be to, jeigu nejaučiame nors nežymaus oro judejjimo ar slègio skirtumo, darosi tvanku, blogeja savijauta, darbingumas. Dar vienas pavojus - alergija. Viena iš pagrindinių alergijos priežasčių yra dèl prastos ventiliacijos susikaupęs blogas oras. Vẻdinimo sistema turi vieną esminę užduotị: ji turi pašalinti visus patalpoje susikaupusius oro teršalus ir pakeisti juos grynu oru. Oro kondicionavimas - tai sukūrimas ir palaikymas uždarose patalpose, transporto priemonèse temperatūros, reikiamo drègnumo, švarumo, oro judèjimo greičio, kurie būtų patys palankiausi žmonių savijautai. Šildymo sistema šaltuoju metų laiku palaiko reikiamą vagonų temperatūrą. Vagono lubose yra šviestuvai su dieninès šviesos lempomis. Virš kiekvienos miegamosios vietos numatyti sofitai, kurie suteikia keleiviui galimybę skaityti tamsiu paros metu.

Reikiama vagono vidaus temperatūra užtikrina gerą keleivio ir aptarnaujančio personalo savijautą.

Sanitarinių mazgų (tualetų) tipas (atviro tipo ar vakuuminis) ir būklè. Tolimojo ir vietinio susisiekimo keleiviniuose vagonuose turi būti ịrengti du uždaro tipo sanitariniai mazgai, o bagažo ir restorano vagonuose - viena tualeto patalpa. Kiekviename sanitariniame mazge turi būti kriauklè su porciniais čiaupais, unitazas su plovimo mechanizmo pedalu, veidrodis, tualetinio popieriaus déžutè, lentynèlè ir kt. Sanitarinio mazgo konstrukcija ir apdailos medžiagos parenkamos pagal higienos reikalavimus, kad patalpą būtų galima išplauti žarna ir nute- 
kètų vanduo (Bazaras, Dundulis 1996). Esant vagone uždaro tipo tualetams, keleiviai jais gali naudotis traukiniui stovint, neteršiama aplinka.

Gultų konstrukcija (viršutinių gultų saugos diržai), specialiosios priemonès neigaliesiems. Nuo gultų konstrukcijos priklauso keleivių poilsis, o nesant viršutinių gultų saugos diržų - sveikata (užmigęs keleivis gali nukristi, susižeisti). Minkštasuolių kokybė, gobeleno spalva turi reikšmès vagono interjerui. Specialios priemonès užtikrintų patogią kelionę neigaliems keleiviams: neigaliujų keltuvai, tualetai.

Irengtas nuolat veikiantis dušas. Nuolat veikiantis dušas suteiktų keleiviams daugiau komforto: atsirastu galimybė prireikus išsimaudyti, išsiplauti galvą.

Specialios kupé dviračiams vežti. Kai traukinyje yra įrengtos specialios kupẻ dviračiams vežti, keleiviai su savimi gali vežtis neišardytus dviračius.

Rūkyti skirtos vietos. Saugiai ir patogiai irrengtose, rūkyti skirtose vietose keleiviai kelionès metu gali rūkyti.

Radijo mazgas ir jo centralizuotas jjungimas ir išjungimas. Traukinyje esant irengtam radijo mazgui, traukinio viršininkas tarpvagoniniu radijo ryšiu (per garsiakalbi) gali teikti keleiviams informaciją apie traukinio išvykimo ir stovèjimo laika, vežimo taisykles, traukinyje teikiamas paslaugas. Kelionès metu keleiviai gali klausytis radijo stočių transliuojamų laidų, populiariosios ir klasikinès muzikos kūrinių.

Restorano vagonas. Restorano vagone kelionès metu galima pavakarieniauti arba papusryčiauti. Esant įrengtiems skystujų kristalu televizoriams ir stereoaparatūrai, galima žiūrèti filma, muzikinị vaizdo klipa, klausytis muzikos.

Palydovo skubaus iškvietimo į kupé galimybè. Keleivių kupe esant įrengtam palydovo skubaus iškvietimo jungikliui, keleivis gali iškviesti palydovą neišeidamas iš kupè.

Galimybė pasinaudoti plaukų džiovintuvu, drabužių lygintuvu. Plaukų džiovintuvu galima išdžiovinti plaukus (pasidaryti šukuosena). Tai ypač džiugintų keleives moteris. Ilgoje kelionèje visada sunku išsaugoti nepriekaištingus drabužius. Traukinyje îrengus buitinę kupè, kurioje būtų drabužiams lyginti skirtos priemonés, pvz., lyginimo lenta, lygintuvas, keleivis prireikus galètu jais pasinaudoti.

\subsubsection{Kriterijai, susieti su kelionès traukiniu proceso organizavimu ir technologija}

Formuluojami ir pagrindžiami kriterijai, susieti su kelionès traukiniu proceso organizavimu ir technologija.

Traukinių išvykimas ir atvykimas laiku. Labai svarbu, kad traukiniai vyktų pagal numatyta grafika, kadangi véluojantys traukiniai sukelia nepatogumu ir pačiam keleiviui (gali pavèluoti i kitos rūšies transporta, jeigu vyksta su persèdimu), ir ji sutinkantiesiems, kuriems tenka ilgai laukti stotyje. 
Maisto davinio keleiviams pateikimas už i bilietą îskaičiuotą kainą. Jeigu i bilieto kainą (nesvarbu, kokia būtų vagono kategorija) būtų ịskaičiuotas maisto davinys, keleiviui nereikètų vežtis savo maisto arba eiti į restorano vagoną.

Patalynès pateikimas, paklojimas ir jos būklè. Švari, geros kokybès patalynè gero poilsio garantas.

Maisto ir gérimų užsakymo iš restorano ir atnešimo ị kupe galimybė (per vagono palydova). Keleiviui, nenorinčiam ar negalinčiam nueiti i restorano vagoną, palydovas gali pasiūlyti meniu ir keleivio užsakymu patiekalai specialiuose termokonteineriuose atnešami ị kupè.

Spaudos platinimas traukinyje. Keleiviui, kuris nenusipirko spaudos prieš kelionę traukiniu, tačiau kelionès metu panoro paskaityti, vagono palydovas gali pasiūlyti pirkti laikraščių ar žurnalų.

Prieiga prie interneto. Sparčiai tobulejjančios informacinès technologijos tapo neatsiejama kasdienio gyvenimo dalimi. Internetas suteikia milžiniškų galimybių darbui, pramogoms, bendravimui. Todèl yra svarbu ir traukinyje keleiviams suteikti galimybę pasinaudoti informacinių technologijų ir telekomunikacijų teikiamais privalumais (sužinoti reikiamą informaciją pasinaudoti elektroniniu paštu ir kt.).

Kelionès bilieto pirkimo traukinyje galimybe (iš traukinio viršininko). Pirkti bilietą traukinyje iš traukinio viršininko patogu kasoje nesuspejusiems jo nusipirkti keleiviams.

Vietų restorano vagone rezervavimo galimybè. Keleiviams patogu per vagono palydovą rezervuoti vietas restorano vagone, jeigu traukinyje važiuoja daug keleivių ir jie nèra tikri, kad nueję i restoraną ras laisvų vietų.

Taksi iškvietimo paslauga. Keleivio, traukinyje užsisakiusio taksi, stotyje laukia taksi automobilis. Traukiniui atvykus į stoti, ši keleivị sutinka stoties rūmų budètojas, kuris palydi keleivi iki taksi automobilio. Keleiviui patogu, nes nereikia pačiam rūpintis transportu.

Galimybė traukinyje atsiskaityti mokejjimo kortele. Mokejimo kortele keleiviui atsiskaityti patogu, kai jis neturi grynujų pinigų arba turi kitos šalies valiuta.

Prekyba suvenyrais traukinyje. Suvenyras - daiktas, susijęs su atsiminimais. Dovana atminimui. LG traukiniuose šiuo metu neprekiaujama suvenyrais. Jeigu traukinyje būtų tokia paslauga, galbūt dovanèlès artimiesiems, draugams nesuspeję̨s nupirkti keleivis pasinaudotu ja.

Traukinyje transliuojamų muzikos kūrinių, informacijos atitiktis keleivių norams. Kaip jau buvo minèta, traukinyje esant irengtam radijo mazgui (per garsiakalbi), keleiviams teikiama informacija, transliuojamos radijo laidos, muzikiniai kūriniai. Tačiau sklindantys garsai malonūs ne visiems keleiviams. Dèl leidžiamos muzikos sulaukiama ir skundų: nepatinkanti ir per garsiai skambanti, dažnai rusiška muzika kartais erzina keleivius. Muzikologès Zitos Kelmickaitès teigimu, viešajame transporte turètu skambèti foninè muzika, kuri neerzintu keleivių (15 min., $2007 \mathrm{~m}$. spalio $18 \mathrm{~d}$.). Ji pripažino, kad viešajame transporte 
skambančią muziką reikètu parinkti pasitarus su muzikos terapijos specialistais. Jei reikètų rinktis tarp rusiškos muzikos, klasikos ir tylos, muzikologè rinktųsi tylą arba ramius klasikinius kūrinius. „Tačiau ir ne visa klasikinè muzika yra tinkama“, - pripažino muzikos ekspertè.

Keleivių bagažo ir daiktų apsauga. Kelionès metu keleivis pats turi rūpintis savo daiktų saugumu. Jeigu visuose vagonuose būtų sumontuoti seifai, keleiviai galètų juose saugoti dokumentus arba kitus vertingus daiktus.

Užsienio medicininių išlaidų draudimo įsigijimo traukinyje galimybè. Sveikatos draudimas užsienyje - tai garantas, kad susirgęs arba patyręs traumą žmogus neliks be medicinos pagalbos ir jam nereikès už ją mokèti savo lèšomis. Keleiviui, neįsigijusiam užsienio medicininių išlaidų draudimo prieš kelionę, būtų patogu ji isigyti traukinyje, pvz., iš traukinio viršininko.

Vizos isigijimo pasienio punkte galimybè. Jeigu vizas galima būtų įsigyti pasienio punkte, būtų išspręsta keleivių iš traukinio išlaipinimo problema. Pavyzdžiui, iš Lietuvos į Rusiją vykstantis keleivis ir neturintis Baltarusijos tranzitinès vizos, iš traukinio Baltarusijos pasienio punkte yra išlaipinamas ir grąžinamas atgal, $\mathfrak{i}$ Lietuvą. Keleivis priverstas nutraukti kelionę: sugadinta jo nuotaika, jam reikia keisti savo planus. Tokiais atvejais būtų labai patogu issigyti vizą pasienio punkte.

Aptarnaujančio personalo išvaizda (uniformos apranga, avalynė, šukuosena, vardinè kortelè). Apranga visuomet buvo itin susijusi su žmogaus įvaizdžiu, kultūra, netgi su visuomenine padètimi. Išvaizda - drabužių aksesuarų suderinimas - atskleidžia, kaip žmogus vertina save ir aplinką. Verslo pasaulyje tai vadinama imonės reprezentavimu. Kadangi aptarnaujančių darbuotojų išvaizda reprezentuoja bendrovę ir formuoja pirmini ispūdị keleiviams, todèl bendra darbuotojų išvaizda privalo atspindèti aukštą ir nepriekaištingą kultūros lygị.

Aptarnaujančio personalo bendravimo kultūra su keleiviais ir tarpusavyje. Bendravimo kultūra mūsų gyvenime vaidina labai svarbų vaidmeni. Ji suartina žmones, harmonizuoja jų tarpusavio santykius, sukuria interesų pusiausvyrą ir darną. Be žmonių bendravimo neįmanoma jokia žmogiška veikla. Bendravimas tai savotiškas menas. Traukinio darbuotojui bendraujant su keleiviu, taip pat ir su savo kolega, labai svarbu gerbti pašnekova, jo isitikinimus, tolerantiškai žiūrèti ị kai kuriuos jo trūkumus. Svarbu būti taktiškam, mandagiam, nuoširdžiam. Pokalbiuose išryškejja asmens savitumas ir kultūros požymiai.

Aptarnaujančio personalo užsienio kalbos mokejjimas. Lietuvai tapus ES nare, traukiniuose padaugèjo užsieniečių, todèl mokèti bent vieną užsienio kalbą yra didelis traukini aptarnaujančio personalo privalumas, leidžiantis keleivị maloniai aptarnauti, suteikti jam reikalingą informacija.

Muitinès ir pasienio pareigūnų kompetencija, objektyvumas ir bendravimo su keleiviais kultūra. Muitinès ir pasienio pareigūnai yra šalies vizitinè kortelè, todèl savaime suprantama, kad keleiviai kreipia dèmesi $i$ jų bendravimo kultūra, aprangą išvaizdą. Muitinès ir pasienio pareigūnai pirmieji reprezentuoja savo šalị. 


\subsubsection{Kriterijai, susieti su kelionès kaina}

Formuluojami ir pagrindžiami kriterijai, susieti su kelionès traukiniu kaina.

Bilieto kaina. Ji sudaro didžiają kelionès išlaidų dalį. Bilieto kaina yra labai aktuali dažnai (pvz., verslo reikalais) traukiniu keliaujantiems keleiviams.

Restorano vagone parduodamų patiekalų kaina ir kokybè. Ji svarbi dažnai keliaujantiems keleiviams, kurie mègsta restorane ne tik vakarieniauti, bet ir pusryčiauti.

Laikraščiu ir žurnalų kaina. Spaudos kaina yra sudedamoji kelionės išlaidų dalis (jeigu keleivis perka spaudą traukinyje).

Užsienio medicininių išlaidų draudimo kaina. Užsienio medicininių išlaidų draudimo polisą privalo turèti kiekvienas keleivis, vykstantis į kitą šalị. Jo kaina priklauso nuo laiko trukmès, kuri jis praleis kitoje šalyje. Dažnai keliaujantiems i užsieni keleiviams ji yra aktuali.

Vizų kaina. Vizų kaina taip pat yra labai svarbi dažnai keliaujantiems keleiviams, ypač tada, kai važiuojant i vieną šali, kitą šali reikia pervažiuoti tranzitu. Tokiu atveju privaloma issigyti ir tranzitinę vizą (pavyzdžiui, važiuojančiam i Rusiją Lietuvos piliečiui reikia turèti ir Baltarusijos tranzitinę viza).

Keleivinio vagono su dvivietemis kupé maisto davinio (iskaičiuoto i bilieto kaina) pateikimas. Pirmos klasès miegamojo vagono su dviejų vietų kupe bilietas yra brangus (apie $700 \mathrm{Lt}$ ). Svarbu, kad šio vagono keleiviams būtų pateikiamas (iskaičiuotas i bilieto kaina) maisto davinys: vakarienė ir pusryčiai.

\subsubsection{Kriterijai, susieti su kelionès traukiniu saugumu}

Formuluojami ir pagrindžiami kriterijai, susieti su kelionès traukiniu saugumu.

Gaisro gesinimo priemonių buvimas ir būklè. Keleivinių vagonų priešgaisrinè sauga užtikrinama neleidžiančiomis kilti gaisrui sistemomis, efektyvia priešgaisrine apsauga ir organizacinèmis techninemis priemonemis. Keleiviniai vagonai turi būti aprūpinti pirminèmis gaisro gesinimo priemonèmis (gesintuvais), taip pat naujuose keleiviniuose vagonuose turi būti irengtas automatinis priešgaisrinès signalizacijos irenginys (UPS), galintis nustatyti ir pranešti apie gaisro kontroliuojamose patalpose požymius. Kiekvieno vagono elektros irenginių valdymo pulte pastatomas automatinis miltelinis arba aerozolinis gaisro gesinimo įrenginys.

Pirmosios medicinos pagalbos priemonių buvimas. Traukinio vaistinèlëje esantys medikamentai naudojami keleiviui susižeidus, nusideginus.

Greitosios medicinos pagalbos iškvietimo galimybè. Susirgus keleiviui (susižeidus, prasidejus gimdymui, jei itariama, kad keleivis susirgo infekcine liga ir kt.), kai pirmoji medicinos pagalba yra nepakankama, artimiausioje stotyje (radijo ryšiu per traukinio mašinista) kviečiami medicinos darbuotojai. 
Ašidèžių perkaičio signalizacijos veikimas. Vagono ašidèžiu perkaičio kontrolès signalizacija užtikrina traukinio eismo saugumą. Ji kontroliuoja ašidèžių ikaičio temperatūrą (garso ir šviesos signalas įspejja apie ašiděžių ịkaiti).

Avarinių išejjimų buvimas. Avarinių išèjimų skaičius ir jų vieta turi užtikrinti saugu keleivių evakavimą gaisro ar kitu nenumatytu ir keleivių sveikatai ar gyvybei pavojingu atveju.

Turèklų, laiptelių, perejimo aikštelių, durų ir spynų tvarkingumas. Visi keleivinių vagonų kẻbulai turi laiptelius įeiti ir išeiti į aukštas ir žemas platformas. Abiejose duru pusèse šoninèje kèbulo sienoje itvirtinti išoriniai turèklai, kad būtų patogu įeiti i vagoną nuo aukštų platformų. Traukiniui važiuojant pereiti iš vieno vagono i kitą galinèse kèbulo rẻmo sijose šarnyriškai įtvirtinti tarpiniai skydai. Kai gretimų sukabintų vagonų skydai yra nuleisti žemyn, jie remiasi i specialius kronšteinus, užeina vienas ant kito ir sudaro ištisini perejjimo tilteli. Keleivinių vagonų durys būna suveriamosios ir stumdomosios - nelygu kokio tipo yra vagonas ir kur jos irengtos. Visoms durims keliami vienodi reikalavimai: jos negali traumuoti keleivių, turi fiksuotis uždarytos, o kai kuriais atvejais ir atidarytos, turèti unifikuotus užraktus (Bazaras, Dundulis 1996).

Rankinio stabdžio būklè ir veikimas, stabdų būklè. Lokomotyvai, keleiviniai, dyzelinių ir elektrinių traukinių vagonai turi turèti rankinius stabdžius. Riedmenų rankiniai stabdžiai turi būti prižiūrimi remiantis nustatytomis normomis, o jų spaudimas turi atitikti nustatytus ir geležinkelio valdytojo patvirtintus skaičiavimus (Techninio geležinkeliu naudojimo... 1996). Rankiniu stabdžiu yra itvirtinami vagonai ir sąstatai stoties keliuose. Traukinio lokomotyvo mašinistui signalizuojant signalą „Stabdyti“ (trys ilgi švilptelèjimai), visu vagonų palydovai privalo užsukti, o po mašinisto signalo „Atleisti stabdžius“ (du ilgi švilptelèjimai) atleisti rankinius stabdžius (Geležinkelių signalizacijos taisyklès, 1998). Keleiviniame vagone yra 4 atlenkiami stabdai, kurie privalo būti užplombuoti.

Policijos pareigūnų iškvietimo galimybè. Jeigu keleivis važiuoja be bilieto ir atsisako ji pirkti ar užmokèti baudą arba yra neblaivus, traukinyje nesilaiko viešosios tvarkos taisykliu, geria alkoholinius gèrimus, trikdo kitų keleivių ramybę, veža didesnio svorio nešuli negu numatyta, traukinio viršininkas privalo ispèti ji ir, jeigu šis nevykdo traukinio viršininko reikalavimų, radijo ryšiu per lokomotyvo mašinistą iškviesti artimiausios stoties policijos pareigūnus. Artimiausios stoties policijos pareigūnus traukinio viršininkas privalo kviesti gavęs pranešimą apie išdaužytus iš išorès traukinio langus, sprogimą vagone, traukinio apšaudymą iš išorès bei šaudant vagone. Policijos pareigūnai kviečiami ir vagystès atveju (Keleivinio traukinio viršininko... 2001).

Suformuluoti ir pagristi 16 (A grupè), 19 (B grupè), 6 (C grupè) ir 8 (D grupè) keleivių vežimo (kelionès traukiniu) kokybę rodantys kriterijai. Kelionès tarptautiniu traukiniu kokybės A, B, C, D kriterijų grupių schema pateikta 2.4 paveiksle. 


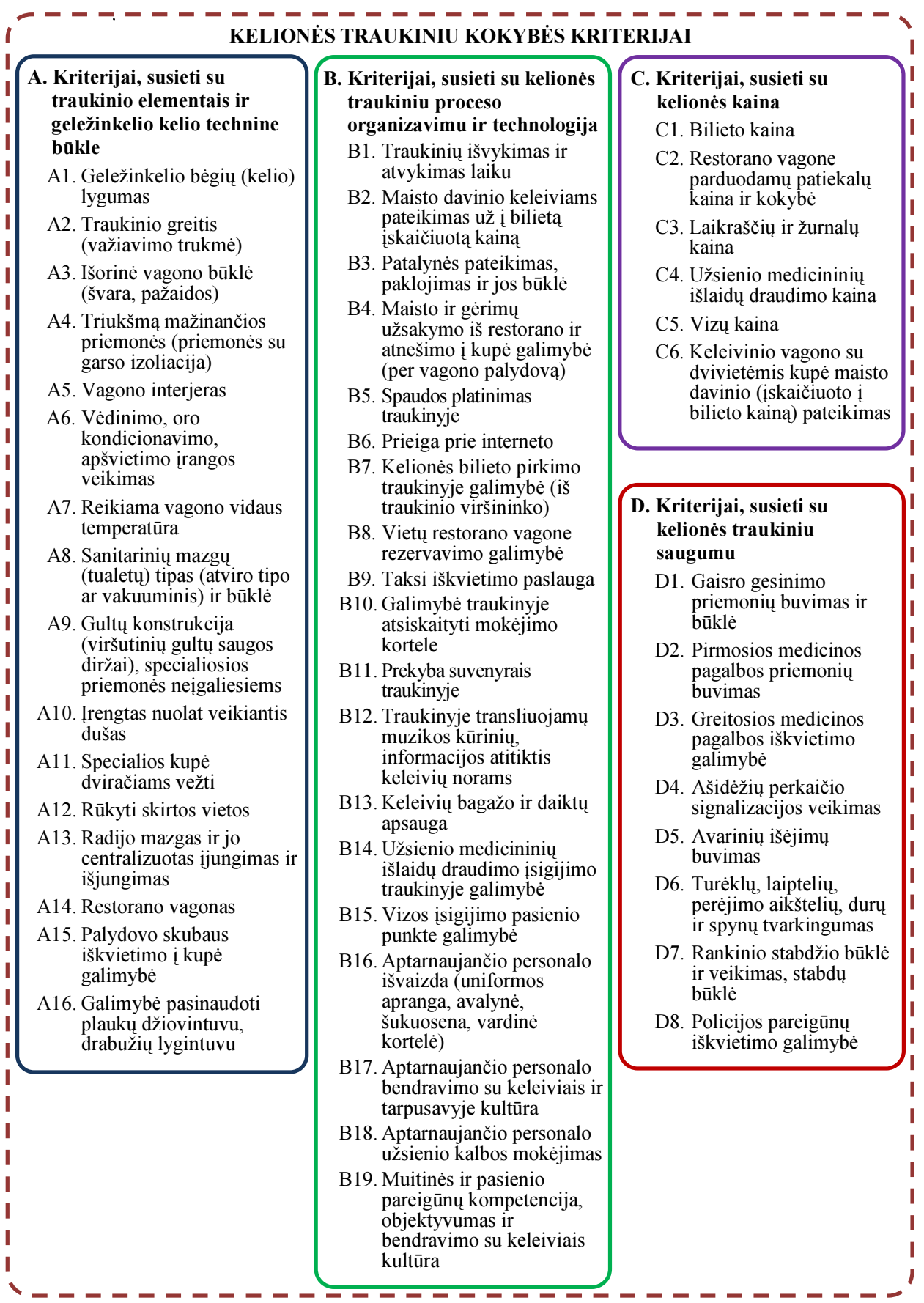

2.4 pav. Kokybès kriterijų A, B, C, D grupių schema

Fig. 2.4. A diagram of railway trip quality criteria groups A, B, C, D 


\subsection{Kelionès traukiniu patogumo samprata}

Kaip jau buvo minèta, kokybę sunku tiesiogiai išreikšti bei išmatuoti kokiu nors vienu kriterijumi. Kelioneje traukiniu keleivi supa tam tikra aplinka (2.5 pav.). Komfortas - tai aplinka, supanti žmogų. Pavyzdžiui, komfortą apibūdina temperatūra, oro drègmè, apšvietimas, triukšmo lygis, dulkètumas, vibracija ir pan. Keleivi veikia šie pagrindiniai veiksniai: psichologinis klimatas, vizualioji aplinka, mikroklimatas vagono viduje, fizinè tarša ir mechaninè tarša. Psichologiniam klimatui įtakos turi keletas charakteristikų: bendravimas su kitais, traukiniu važiuojančiais keleiviais, su traukini aptarnaujančiais darbuotojais, o tarptautiniame traukinyje - su muitinès ir pasienio pareigūnais. Traukinio viršininkui svarbu žinoti esamą psichologinio klimato traukinyje lygi ir nepasitenkinimo šaltinius, nes daugeli psichologiniam klimatui itakos turinčių veiksnių galima keisti, pvz., sudrausminti nepaisantị elgesio normų keleivį arba aptarnaujančio personalo darbuotoją, pašalinti arba sumažinti teikiamų paslaugų trūkumus, pagelbèti ivvykus nenumatytai situacijai. Darbuotojų asmens savybių ir pageidaujamų tai pareigybei psichologinių reikalavimų atitikimas yra svarbus veiksnys, lemiantis gerus santykius su keleiviais ir psichologini klimatą darbe.

Žmogus ji supančią aplinką suvokia vizualiai ir dèl to patiria vienokių ar kitokių estetinių emocijų. Nors keleivị veikia įvairūs veiksniai, tačiau daugelis jų tiesiogiai susije su vagono konstrukcijomis (irengimu), interjero estetika. Neigiamą itaką keleivio savijautai gali daryti netinkamas vagono patalpų dydis ir struktūra. Svarbu ir vaizdas už lango: tamsa arba lietus gali slègti, saulèta diena ar vasaros žaluma suteikti gerų emocijų.

Keleivio patogumui nepaprastai svarbus yra mikroklimatas vagono viduje. $\mathrm{Kad}$ patogiai jaustųsi, patalpos oro temperatūra turètų būti nuo 18 iki $20{ }^{\circ} \mathrm{C}$ (apsirengusiam drabužiais), santykinè oro drègmè 40-60\%. Oras patalpose turétu judèti iki $0,3 \mathrm{~m} / \mathrm{s}$ greičiu. Védinimo reikia tokio, kad per valandą patalpose pasikeistu bent pusè oro. Vienam suaugusiam žmogui reikalingas minimalus $14,4 \mathrm{~m}^{3} / \mathrm{h}$ lauko oro kiekis, tada $\mathrm{CO}_{2}$ koncentracija patalpose neviršija leidžiamos normos. Blogai védinamose patalpose kaupiasi anglies dioksidas, drègme ir teršalai, didèja mikrobiologinis užterštumas. Kvapai daro neịtikètinai didelị efektą patalpu energetikai ir jose esantiems žmonèms. Blogas kvapas vagone neigiamai veikia keleivio savijauta.

Fizinè vagono tarša - tai netinkamas apšvietimas, vibracija, triukšmas, lètèjimo ir greitejimo pagreičiai. Kadangi apšvietimas yra energijos paskirstymas, gerinantis daiktų matomuma, esant jam netinkamam, keleivis gali patirti nepatogumų, pvz., skaitydamas. Vagono vibracija blogina keleivio savijauta, mažina aptarnaujančio personalo darbingumą. Traukinio judèjimas yra ịvairių veikiančių jègu padarinys. Traukinys, o tuo pačiu ir vagonas, gali judèti tolygiai (pastoviu greičiu), lètedamas arba greitedamas (įsibejgèdamas). Viena iš pagrindinių stab- 
dymo charakteristikų yra lètèjimo pagreitis, o ỉsibègèjimo charakteristikų - greitejjimo pagreitis. Nuo stabdymo ir ísibègejjimo efektyvumo priklauso vagono dinaminès savybès, o tuo pačiu ir keleivio važiavimo patogumas.

Vibracija ir triukšmas gali kelti pavojų didelès sveikatos rizikos grupès žmonèms. Nors keleivis traukinyje būna, palyginti, neilgą laiką, kad tai turètų itakos jo sveikatai, tačiau ji gali erzinti (neleisti miegoti) vibracija ar bėgio ir rato sąveikos garsas. Klausą neigiamai veikia ir didelis muzikos triukšmas, garsi bendrakeleivių kalba. Be neigiamo poveikio klausai, muzikos triukšmas pablogina žmogaus centrinès nervų sistemos darbą.

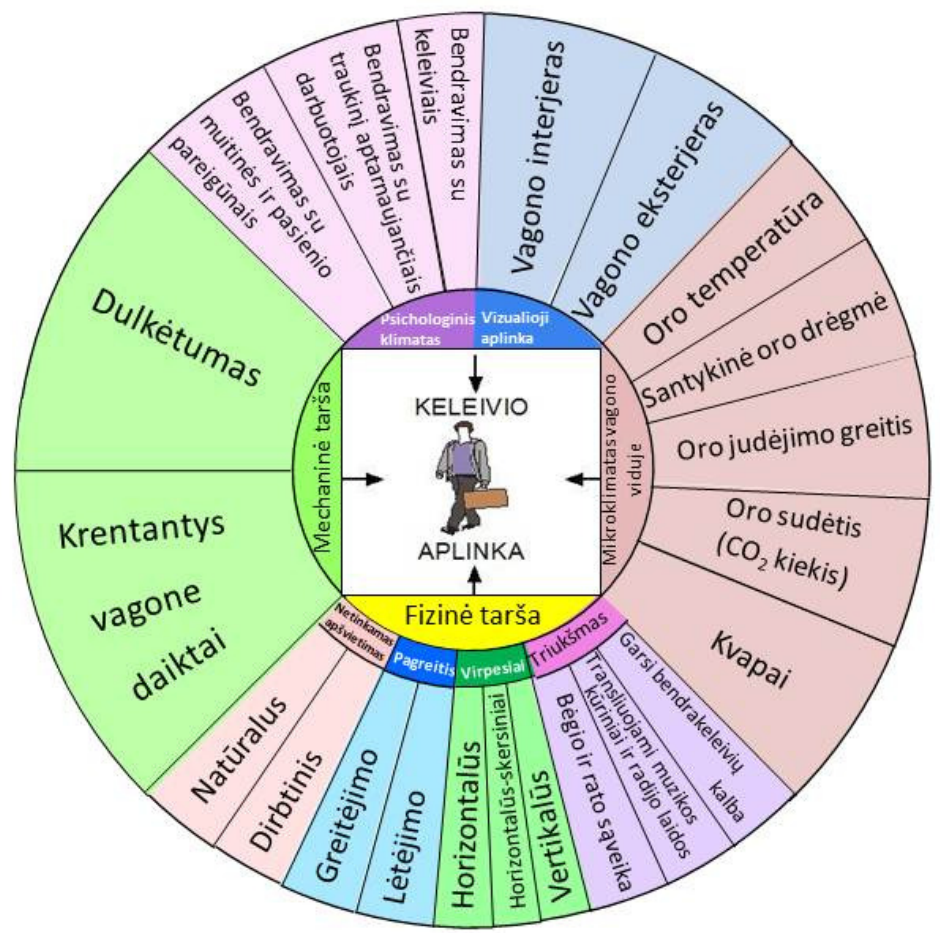

2.5 pav. Kelioneje traukiniu keleiviui itakos turintys veiksniai

Fig. 2.5. Factors influencing a passenger during the trip by train

Dulkètumą, krintančius vagone daiktus (pvz., traukiniui staigiai stabdant krintantis nuo lentynų keleivių bagažas, nuo stalo - indai, nuo gulto - kitas, saugos diržu neprisisegęs keleivis) galima priskirti mechaninei vagono taršai. Kenksmingas dulkių poveikis labiausiai priklauso nuo jų fizinių ir cheminių savybių, dalelių dydžio, formos, koncentracijos ore. Dauguma dulkių kenkia kvèpavimo organams, tačiau kai kurios gali sukelti odos ir kitokias ligas. I vagono 
vidų dulkès iš aplinkos patenka pro atidarytus arba nesandarius langus, vagonui šildyti naudojant akmens anglis.

\subsection{Kelionès traukiniu proceso modelis ir jo pagrindimas}

KTK išreiškiama kiekybinių ir kokybinių kriterijų visuma. Būtų patogu turèti vieną skaičių, kiekybiškai įvertinantị visų kriterijų itaką KTK. Susisteminti keturiu grupių 49 KTK kriterijai (2.4 pav.). Taikant ekspertinių tyrimu metodus nustatomi jų svorio vidurkiai ir kriterijų grupių svarba (pirmumas). Kriterijų grupių svarbą rodo vidutinis svorio koeficientas $\bar{Z}_{g}^{*}$. Keleivių vežimo kokybei tarptautiniame traukinyje (maršrute) ivertinti sukurtas kiekybinis metodas ir rodiklis $K\left(K=K_{A}+K_{B}+K_{C}+K_{D}, K=0-1\right)$, leidžiantis vienu skaičiumi išreikšti vieno maršruto KTK (Sivilevičius et al. 2012).

\subsubsection{Kriterijų, susietų su traukinio elementais ir geležinkelio kelio technine būkle, vertinimo modelis}

Suformuluota ir pagrista 16 kriterijų, susietu su traukinio elementais ir geležinkelio kelio technine būkle (2.4 pav.), kuriu KKVR $K_{A}$ dèmuo su iš ekspertinių tyrimų apskaičiuojamu vidutiniu svorio koeficientu $\bar{Z}_{A}^{*}$ ir kiekvieno kriterijaus svorio vidurkiu $\bar{Q}_{j}$ apskaičiuojamas pagal formulę:

$$
K_{A}=\bar{Z}_{A}^{*} \cdot\left(\bar{Q}_{A 1} \cdot x_{A 1}+\bar{Q}_{A 2} \cdot x_{A 2}+\ldots+\bar{Q}_{A 16} \cdot x_{A 16}\right),
$$

čia: $K_{A}$ - tarptautinio traukinio kokybès kompleksinio vertinimo rodiklis (KKVR) $\left(K_{A}\right.$ kinta nuo 0 iki 1$)$; $\bar{Z}_{A}^{*}$-triju kategorijų $(\mathrm{K}, \mathrm{P}, \mathrm{A})$ respondentų ir ekspertu nuomonių apie A kriterijų grupès svarbą vidutinis svorio koeficientas; $\bar{Q}_{A 1}, \ldots, \bar{Q}_{A m}-\mathrm{A}$ kriterijų grupés $j$-ojo $(j=1,2, \ldots, m)$ kriterijaus svorio vidurkis, nustatytas ekspertų metodu; $x_{A 1}, \ldots, x_{A m}-\mathrm{A}$ kriteriju grupès $j$-ojo $(j=1,2, \ldots, m)$ kriterijaus kintamasis dydis, nustatytas iš tyrimų ir norminiu (reikiamų, siektinu) rodiklių lyginimo, iš kurių verčiu apskaičiuojamas faktiškas kriterijaus lygmuo, kintantis nuo 0 iki 1 . Keleivių vežimo tarptautiniu traukiniu KKVR, ivertinančiam traukinio elementų kelionès proceso organizavimo ir technologijos įtaką, nustatyti būtina apskaičiuoti kiekvieno kriterijaus kintamuosius dydžius $x_{A 1}, \ldots, x_{A 16}$.

1. Geležinkelio bėgių (kelio) lygumas. Bègių kelio geometriniai parametrai yra kelio vėžès plotis, bėgių įdubos, bėgiu padètis pagal lygi ir jų padètis plane, perkrypos. Bègių kelio geometriniai parametrai vertinami naudojan- 
tis sąlygine stačiakampe koordinačių sistema, orientuota ị kelią pagal laikrodžio rodyklę.

Bègių vèžè - tai mažiausias atstumas tarp linijų, išvestų statmenai bėgių galvučių viršui ir liečiančių bègiu galvutès vidines briaunas (2.6 pav.). Bègių vèžès plotis visada matuojamas $13 \mathrm{~mm}$ žemiau bėgio galvutès viršaus (Savaeigio kelio matavimo vagono EM-140... 2012).

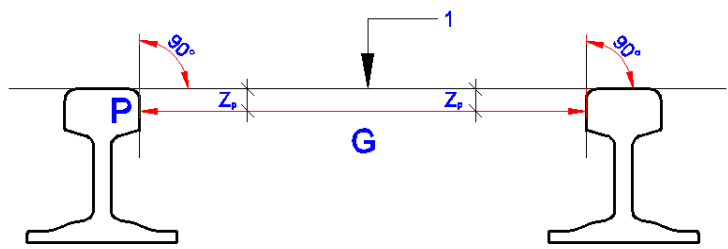

2.6 pav. Bègių vèžès plotis: $\mathrm{G}$ - bėgių vèžès plotis; 1 - bègiu galvučių viršus;

$\mathrm{P}$ - linija, statmena bėgio galvutès viršui ir liečianti begio galvutès vidinę briauną; $\mathrm{Zp}$ - atstumas nuo bėgio galvutès viršaus, lygus $13 \mathrm{~mm}$

Fig. 2.6. The gauge: $G$ is the gauge, 1 is the rail head top surface;

$\mathrm{P}$ is the line perpendicular to the rail head top and tangential to the inner edge of the rail head; $\mathrm{Zp}$ is the distance from the rail head top equal to $13 \mathrm{~mm}$

Šaltinis: Savaeigio kelio matavimo vagono EM-140... 2012

Bègio galvutės viršaus lygio nuokrypis bet kuriame bègyje (2.7 pav.), išreikštas kaip nukrypimas $Z$ kryptimi nuo horizontalios atskaitos linijos (ant kelmačio matavimo rèmo su fiksuota lygiagrečia bègiams padètimi, esančios inercinès matavimo sistemos sukurta menama horizontali atskaitos linija), kuris apima nustatytus bangų ilgius ir yra apskaičiuojamas atsižvelgiant $\mathfrak{i}$ kelis vienas po kito atliktus matavimus.

Aukščio skirtumas tarp dviejų gretimų bėgių galvučių viršaus plokštumų (2.8 pav.) skaičiuojamas pagal kampą tarp bėgio galvutès viršaus ir horizontalios atskaitos linijos (ant kelmačio matavimo rèmo su fiksuota lygiagrečia bejgiams padètimi, esančios inercinès matavimo sistemos sukurta menama horizontali atskaitos linija). Jis yra išreiškiamas kaip stačiojo trikampio ižambinès, lygios nominalaus bègių vėžès pločio ir bègio galvutès pločio sumai, suapvalintai $10 \mathrm{~mm}$ tikslumu.

Bet kurio bėgio taško $\mathrm{P}$ padèties nuokrypis $\mathrm{Y}_{\mathrm{p}}$ dydžiu $\mathrm{Y}$ ašies kryptimi (2.9 pav.), išreikštas kaip nuokrypis nuo vidurinès horizontalios atskaitos linijos (ant kelmačio matavimo rèmo su fiksuota lygiagrečia bėgiams padètimi, esančios inercinès matavimo sistemos sukurta menama horizontali atskaitos linija), apimantis nustatytus bangu ilgius ir yra apskaičiuojamas atsižvelgiant $\mathfrak{i}$ kelis vienas po kito atliktus matavimus. 

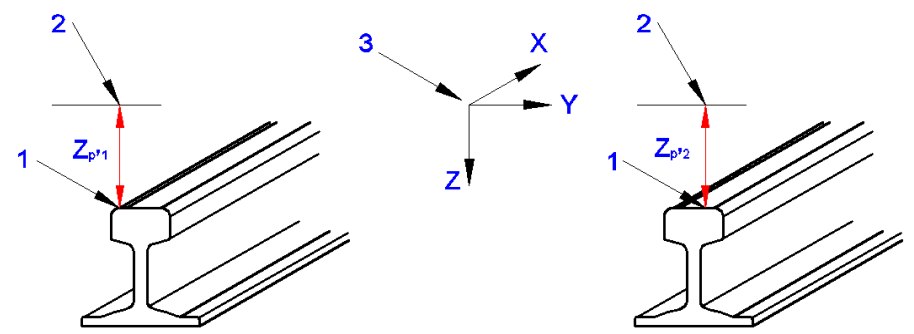

2.7 pav. Bègiu i̇dubos: 1 - bėgio galvutès viršus; 2 - horizontali atskaitos linija (ant kelmačio matavimo rèmo su fiksuota lygiagrečia bègiams padètimi, esančios inercinès matavimo sistemos sukurta menama horizontali atskaitos linija);

3 - X, Y, Z - geležinkelio kelio koordinačiu sistemos ašys; Zp'1 ir Zp'2 - bėgio nuokrypis nuo atskaitos linijos

Fig 2.7. Rail dents: 1 the rail head top surface; 2 the horizontal reference line (an imaginary line created by the inertial measurement system of the track geometry car and located on the measuring frame, which is parallel to the tracks);

$3 \mathrm{X}, \mathrm{Y}, \mathrm{Z}$ the axes of the coordinate system of the track; Zp'1 and Zp'2 rail deviation from the reference line Šaltinis: Savaeigio kelio matavimo vagono EM-140... 2012

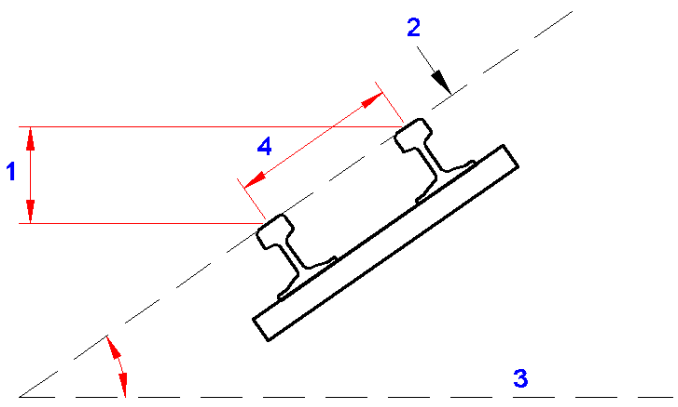

2.8 pav. Bẻgių padètis pagal lygi: 1 - bẻgių padetis pagal lygi; 2 - bejgiu galvučių viršus; 3 - horizontali atskaitos linija (ant kelmačio matavimo rèmo su fiksuota lygiagrečia bėgiams padètimi, esančios inercinès matavimo sistemos sukurta menama horizontali atskaitos linija); 4 - ižambinè

Fig. 2.8. The position of rails by level: 1 the position of rails by level; 2 the rail head top surface; 3 the horizontal reference line (an imaginary line created by the installed inertial measurement system of the track geometry car and located on the measuring frame, which is parallel to the tracks); 4 the hypotenuse Saltinis: Savaeigio kelio matavimo vagono EM-140... 2012 


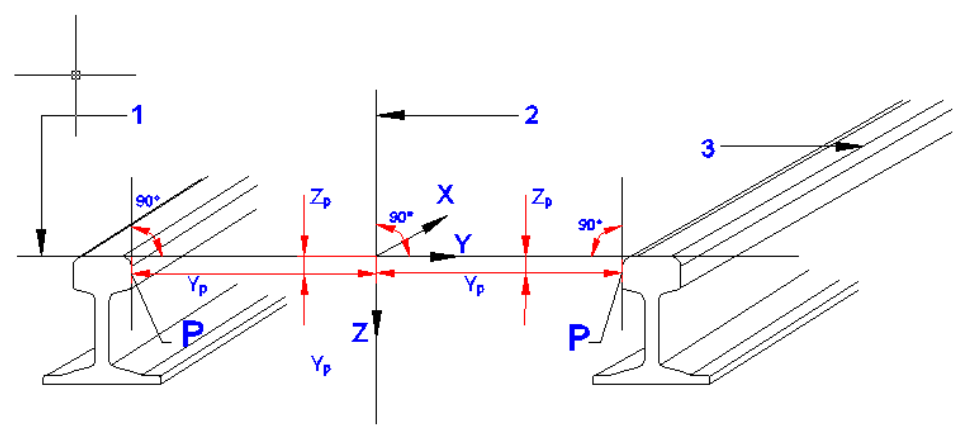

2.9 pav. Bègių padètis plane: 1 - bėgių galvučių viršus; 2 - vidurinė horizontali atskaitos linija (ant kelmačio matavimo rèmo su fiksuota lygiagrečia bėgiams padètimi, esančios inercinès matavimo sistemos sukurta menama horizontali matavimo rèmo vidurio linija); 3 - bėgio galvutès viršaus ašinė linija; $\mathrm{P}$ - taškas ant bejgio galvutès vidinès briaunos; $\mathrm{Y}_{\mathrm{p}}$ - taško $\mathrm{P}$ nuokrypis nuo atskaitos linijos; $\mathrm{Z}_{\mathrm{p}}$ - atstumas nuo bejgio galvutès viršaus lygus $13 \mathrm{~mm}$

Fig. 2.9. The position of rails on the plan: 1 the rail head top surface; 2 the horizontal reference midline (an imaginary midline created by the inertial measurement system of

the track geometry car and located on the measuring frame, which is parallel to the tracks); 3 the centre line on the rail head top surface; $P$ the point on the rail head inner edge; $Y_{p}$ the deviation of the point $P$ from the reference line; $Z_{p}$ the distance from the rail head top surface equal to $13 \mathrm{~mm}$

Kiekvienas kelio geometrinių parametru nuokrypis nuo normos vertinamas atsižvelgiant i jo daromą poveiki keliui ir riedmenims bei kelio liekamujų deformacijų kaupimąsi. Išskiriami I-IV laipsnių nuokrypiai.

Bègiu kelio kokybei apibūdinti naudojamas kelio kokybès indeksas (KKI), kuris leidžia stebèti kelio geometrinių parametrų pokyčius. Suminis KKI skaičiuojamas kiekvienam kilometrui sumuojant geležinkelio geometrinio parametro KKI vertes. Suminis KKI, apibūdinantis vertinamo ruožo kokybę nuo „labai geras kelias“ iki „blogas kelias“, gali kisti nuo 0 iki 45 ir daugiau (2.2 lentelè) (Instrukcija K/259. Savaeigio kelio matavimo vagono EM-140... 2012). Blogèjant kelio apibūdinimui, mažinamas traukinių greitis.

KKI ataskaita sukuriama kelmačio programa „EMGraph“. Kelio KKI ataskaitą sudaro vertinamo ruožo, vertinamieji parametrai ir jų vertès.

Taigi, suminis (bendras) KKI skaičiuojamas iš kelmačiu išmatuotų pagrindinių geležinkelio kelio geometrinių parametrų sklaidos įverčių:

$K K I=2 \sigma_{b}=2 \sigma_{P L O T I S}+2 \sigma_{I D K}+2 \sigma_{I D D}+2 \sigma_{T I E K}+2 \sigma_{T I E D}+2 \sigma_{L Y G I S}+2 \sigma_{P E R},(2.2)$

čia: $K K I$ - kelio kokybès indeksas, išmatuotas kiekvienam geležinkelio kelio kilometrui (bedimensis skaičius - Instrukcijoje K/259 (2012), iš tikrujų - mm); $\sigma_{b}-$ bendrasis visu geometrinių parametrų standartinis nuokrypis, mm; $\sigma_{P L O T I S}-$ 
bėgių kelio vėžès pločio, išmatuoto prie 3-ios kelmačio vežimèlio ašies, standartinis nuokrypis, mm; $\sigma_{I D K}-$ kairès pusès bègio įdubos standartinis nuokrypis, $\mathrm{mm} ; \sigma_{I D D}-$ dešinès pusès bègio įdubos standartinis nuokrypis, mm; $\sigma_{T I E K}-$ kairès pusès bègio padèties plane standartinis nuokrypis, $\mathrm{mm} ; \sigma_{\text {TIEK }}-$ dešinès pusès bėgio padèties plane standartinis nuokrypis, $\mathrm{mm} ; \sigma_{L Y G I S}$ - bègiu padèties vienas kito atžvilgiu pagal bègiu galvutès lygi standartinis nuokrypis, mm; $\sigma_{P E R}-$ staigaus nukrypimo pagal bėgių galvutès lygi (perkrypa) standartinis nuokrypis, $\mathrm{mm}$.

2.2 lentelè. Kokybinis kelio būklès įvertinimas KKI

Table. 2.2. Qualitative evaluation of the track (TQI is the track quality index)

\begin{tabular}{|c|c|}
\hline Suminis KKI & Kelio apibūdinimas \\
\hline $0-20$ & Labai geras \\
\hline $21-34$ & Geras \\
\hline $35-44$ & Patenkinamas \\
\hline$\geq 45$ & Blogas \\
\hline
\end{tabular}

Šaltinis: Savaeigio kelio matavimo vagono EM-140... 2012

Kelmatis EM-140 išmatuoja adityvinio modelio (2.2) formulè) komponentų dvigubus standartinius nuokrypius. Kelmatis nepateikia išmatuotų geometrinių parametrų aritmetinių vidurkių.

Tikètina, kad kuo mažesnė geležinkelio kelio kelmačiu išmatuota KKI faktinè verte, tuo aukštesnès kokybès yra kelione traukiniu, nes mažesni yra vagonų virpesiai, o keleiviai nejunta pagreičių. Logiška manyti, kad kiekvieno kilometro išmatuotas suminis KKI, atitinkantis žodini kelio apibūdinimą labai geras, geras, patenkinamas ar blogas, turi atitikti toki pati ir kelionès traukiniu kokybès rodiklio sando $x_{A 1}$, nulemto geležinkelio bègiu (kelio) lygumo, apibūdinimą.

KKVR $K$ dèmens, priklausančio nuo traukinio elementų ir geležinkelio kelio techninès būklès $K_{A}$, sandaugos $\bar{Q}_{A 1} \cdot x_{A 1}$, kintamojo dydžio $x_{A 1}$, rodančio geležinkelio bègiu (kelio lygumo) įtaką vienam kelio kilometrui, vertè skaičiuojama pagal šią formulę:

$$
x_{A 1}=1-\frac{K K I_{f}^{2}}{K K I_{r i b}^{2}},
$$

čia: $x_{A 1}$ - A grupès 1-ojo kriterijaus kintamasis dydis; $K K I_{f}$ - faktiškasis kelmačiu išmatuotas vieno kilometro ilgio ruožo KKI; $K K I_{r i b}$ - ribinis (blogas) kelmačiu išmatuotas vieno kilometro ilgio ruožo KKI.

KKVR $K_{A}$, ivvertinančio geležinkelio bėgiu (kelio lygumo) itaką visam keliui, dèmuo skaičiuojamas pagal šią formulę: 


$$
x_{A 1}=\frac{\sum_{s=1}^{N_{k m}}\left(1-\frac{K K I_{f}^{2}}{K K I_{r i b}^{2}}\right)_{s}}{N_{k m}},
$$

čia: $x_{A 1}$ - A grupès 1-ojo kriterijaus kintamasis dydis; $K K I_{f}$ - faktiškasis kelmačiu išmatuoto viso kelio KKI; $K K I_{r i b}$ - ribinis (blogas) kelmačiu išmatuoto viso kelio KKI; $N_{k m}$ - viso kelio ilgis, $\mathrm{km}\left(s=1,2, \ldots, N_{k m}\right)$.

2. Traukinio greitis (važiavimo trukmè). Saugiam traukinių eismui, atsižvelgiant į viršutinès kelio konstrukcijos, žemès sankasos ir kelio statinių būklę bei riedmenų rūšî, užtikrinti ir pasiekti, kad būtų griežtai laikomasi traukinių eismo grafiko bei Techninio geležinkelių naudojimo nuostatu yra nustatomas didžiausias leidžiamasis traukinių ir lokomotyvų greitis geležinkelio stočių keliais ir tarpstočiais (Dèl didžiausio leistino traukiniu ir lokomotyvu greičio... 2009; Techninio geležinkeliu... 1996). KKVR $K_{A}$, ivvertinančio traukinio greičio (važiavimo trukmès) itaką, dėmuo skaičiuojamas pagal šią formulę:

$$
x_{A 2}=\frac{\sum_{l=1}^{r}\left(1-\frac{\left|\Delta v_{f}\right|}{v_{\text {max }, l}}\right) \cdot l_{l}}{\sum_{l=1}^{r} l_{l}},
$$

čia: $x_{A 2}$ - A grupés 2-ojo kriterijaus kintamasis dydis; $r$ - tarpstočių skaičius $(l=1$, $2, \ldots, r) ; \Delta v_{f}$ - traukinio važiavimo $l$-uoju tarpstočiu faktiškojo ir maksimalaus leidžiamojo greičio pokytis, $\mathrm{km} / \mathrm{h} ; v_{\max , l}$ - didžiausias leidžiamasis traukinio važiavimo greitis $l$-uoju tarpstočiu, $\mathrm{km} / \mathrm{h} ; l_{l}$ - atskirų tarpstočiu ilgiai, $\mathrm{km}\left(L=l_{1}+\right.$ $\left.l_{2}+\ldots+l_{l}\right)$.

3. Išorinè vagono būklè (švara, pažaidos). Išorinei vagono būklei (švarai, pažaidoms) vertinti skiriami šie balai: 0 - vagonas nešvarus, yra pažaidų; 1 - vagonas nešvarus, pažaidų nèra arba vagonas švarus, tačiau yra pažaidų; 2 - vagonas švarus, pažaidų nèra. KKVR $K_{A}$, ivvertinančio vagono švaros, pažaidų itaka, dèmuo skaičiuojamas pagal šią formulę:

$$
x_{A 3}=\frac{\sum_{c=1}^{V}\left(\frac{V K B_{f}}{V K B_{\max }}\right)_{c}}{V},
$$

čia: $x_{A 3}$ - A grupès 3-ojo kriterijaus kintamasis dydis; $V K B_{f}-c$-ojo vagono $(c=1,2, \ldots, V)$ faktiškoji būklè (švara, pažaidos) balais $(0,1$ arba 2$) ; V K B_{\max }-$ didžiausias galimas vagono įvertinimo balas (2 balai); $V$ - sąstato vagonų skaičius. 
4. Triukšmą mažinančios priemonès (priemonès su garso izoliacija). Stacionarių triukšmo šaltinių skleidžiamo triukšmo ribinius dydžius gyvenamuosiuose ir visuomeninès paskirties pastatuose bei jų aplinkoje nustato Lietuvos higienos norma HN 33:2011, ,Triukšmo ribiniai dydžiai gyvenamuosiuose ir visuomeninès paskirties pastatuose bei jų aplinkoje“" (patvirtinta Lietuvos Respublikos sveikatos apsaugos ministro $2011 \mathrm{~m}$. birželio $13 \mathrm{~d}$. isakymu $\mathrm{Nr}$. V604). Kadangi triukšmo lygio vagono salone norminiai dokumentai nenormuoja, todèl išimties atveju galima naudoti palydovo vietai normuotą triukšmo lygị. Būtiniausi reikalavimai dèl darbuotojų apsaugos nuo rizikos jų sveikatai ir saugai (o ypač jų klausai), kurią kelia ar gali sukelti triukšmas, nustatyti „Darbuotojų apsaugos nuo triukšmo keliamos rizikos nuostatuose“" (patvirtinta Lietuvos Respublikos socialinès apsaugos ir darbo ministro ir Lietuvos Respublikos sveikatos apsaugos ministro $2005 \mathrm{~m}$. balandžio $15 \mathrm{~d}$. isakymu Nr. A1103/V-265). Šiuose nuostatuose ribinès triukšmo ekspozicijos vertès ir ekspozicijos vertès veiksmams pradèti (darbuotojų apsaugai nuo veikiančio triukšmo užtikrinti) nustatomos pagal kasdienius veikiančio triukšmo lygius. Ribinè ekspozicijos vertė $\mathrm{L}_{\mathrm{EX}}, 8 \mathrm{~h}=87 \mathrm{~dB}(\mathrm{~A})$. KKVR $K_{A}$, ivvertinančio triukšmą mažinančių priemonių įtaka, demuo skaičiuojamas pagal šią formulę:

$$
x_{A 4}=1-\frac{\sum_{c=1}^{V}\left(\frac{T L_{f}}{T L_{\max , l}}\right)_{c}}{V},
$$

čia: $x_{A 4}$ - A grupès 4-ojo kriterijaus kintamasis dydis; $T L_{f}$ - faktiškas triukšmo lygis $c$-ajame vagone, $\mathrm{dBA} ; T L_{\max , l}$ - leidžiamas triukšmo lygis $c$-ajame vagone, dBA, $V$ - sąstato vagonų skaičius.

5. Vagono interjeras. Vagono interjeras kuria geležinkelio įmonès įvaizdį. Kitas veiksnys, lemiantis vagono interjero reikšmę, - tai gera keleivių ir darbuotoju savijauta. Vagono interjerui vertinti skiriami šie balai: 0 - senam (nemodernizuotam) vagonui, 1 - senam (modernizuotam) vagonui, 2 - naujam vagonui. KKVR $K_{A}$, ivertinančio vagono interjero įtaką, dèmuo skaičiuojamas pagal šią formulę:

$$
x_{A 5}=\frac{\sum_{c=1}^{V}\left(\frac{I_{f}}{I_{\max }}\right)_{c}}{V},
$$

čia: $x_{A 5}$ - A grupès 5-ojo kriterijaus kintamasis dydis; $I_{f}$ - faktiškas $c$-ojo vagono interjero vertinimas balais $\left(0,1\right.$ arba 2 balai); $I_{\max }$ - didžiausias galimas vagono interjero ịvertinimo balas (2 balai); $V$ - sąstato vagonų skaičius.

6. Vėdinimo, oro kondicionavimo, apšvietimo irangos veikimas. Vagono vėdinimo, oro kondicionavimo, šildymo sistemos ir apšvietimo įrangos veikimui vertinti skiriami šie balai: 0 - vagone neveikia nei viena sistema, 1 - vagone 
veikia viena sistema, 2 - vagone veikia dvi sistemos, 3 - vagone veikia trys sistemos, 4 - vagone veikia visos minètos (vagono vėdinimo, oro kondicionavimo, šildymo, apšvietimo) sistemos. KKVR $K_{A}$, ivertinančio vagono vėdinimo, oro kondicionavimo, šildymo sistemos ir apšvietimo įrangos įtaką, dèmuo skaičiuojamas pagal šią formulę:

$$
x_{A 6}=\frac{\sum_{c=1}^{V}\left(\frac{V K A_{f}}{V K A_{\max }}\right)_{c}}{V},
$$

čia: $x_{A 6}$ - A grupès 6-ojo kriterijaus kintamasis dydis; $V K A_{f}-c$-ojo vagono sistemų veikimo vertinimas balais $\left(1,2,3\right.$ arba 4 balai); $V K A_{\max }$ - didžiausias galimas vagone veikiančių sistemų vertinimo balas (4 balai); $V$ - sąstato vagonų skaičius.

7. Reikiama vagono vidaus temperatūra. Vandens šildymo sistema turi užtikrinti patogias sąlygas keleiviams ir traukini aptarnaujantiems darbuotojams, jiems esant vagone. Oro temperatūra vagone, kai lauko temperatūra yra iki -40 ${ }^{\circ} \mathrm{C}$ ir vagonas yra šildomas kietuoju kuru, turi būti ne žemesnè nei $+18{ }^{\circ} \mathrm{C}$. Kai vanduo katile yra šildomas elektriniais kaitintuvais (nuo aukštos itampos $(3000 \mathrm{~V})$ kontaktinio tinklo), oro temperatūra vagone palaikoma automatiniu būdu $22 \pm 2{ }^{\circ} \mathrm{C}$ ribose. Vasarą veikiant oro kondicionieriui $24 \pm 2{ }^{\circ} \mathrm{C}$ ribose.

Jeigu žiemą vidutiné faktinè oro temperatūra vagone atitinka $+22{ }^{\circ} \mathrm{C}$ (2.10 pav.), tai yra aukščiausias kokybès lygis $\left(x_{A 7}=1\right)$. Kai faktinè oro temperatūra yra lygi apatinei leidžiamai, žiemos temperatūra $T_{L Z ̆}=+20{ }^{\circ} \mathrm{C}$ arba lygi viršutinei leidžiamai $T_{U \check{Z}}=+24{ }^{\circ} \mathrm{C}$, tai $x_{A 7}=0$, 5 . Jei vasarą vidutinè oro temperatūra atitinka optimalią vasaros temperatūra, lygią $+24{ }^{\circ} \mathrm{C}$, tai $x_{A 7}=1$. Kai faktiné oro temperatūra atitinka apatinę leidžiamą vasaros temperatūrą $T_{L V}=\bar{T}_{f}=+22^{\circ} \mathrm{C}$ arba kai faktinè temperatūra atitinka viršutinę leidžiamą ribą $T_{U V}=\bar{T}_{f}=+26^{\circ} \mathrm{C}$, tai yra vidutinis kokybès lygis $\left(x_{A 7}=0,5\right)$. Normos nereglamentuoja aukštesnès kaip $+28{ }^{\circ} \mathrm{C}$ ir mažesnès nei $+20{ }^{\circ} \mathrm{C}$ temperatūros vagone vasarą, o žiemą aukštesnès nei $+26^{\circ} \mathrm{C}$.

KKVR $K_{A}$, ivvertinančio reikiamą vagono vidaus oro temperatūrą, dèmuo skaičiuojamas pagal šią formulę:

$$
x_{A 7}=1-\frac{\sum_{c=1}^{V}\left|\frac{\frac{T_{U}+T_{L}}{2}-\bar{T}_{f}}{T_{U}-T_{L}}\right|_{c}}{V},
$$

čia: $T_{L}$ - mažiausia leidžiama oro temperatūra vagone, ${ }^{\circ} \mathrm{C}$. Žiemą, kai kūrenama kietuoju kuru ir lauko temperatūra ne žemesne kaip $-40{ }^{\circ} \mathrm{C}$ ir ne aukštesnè kaip 
$+10{ }^{\circ} \mathrm{C}, T_{L}=18{ }^{\circ} \mathrm{C}$, o kai vanduo šildomas elektra $T_{L}=20^{\circ} \mathrm{C}$ (automatiniu režimu turi būti palaikoma $(22 \pm 2){ }^{\circ} \mathrm{C}$ temperatūra). Vasara, kai veikia kondicionieriai, automatiškai palaikoma vagono temperatūra turi būti $(24 \pm 2){ }^{\circ} \mathrm{C}$, todèl $T_{L}=22{ }^{\circ} \mathrm{C}$ (Вагон пассажсирский купейный... 2002); $T_{U}$ - didžiausia leidžiama oro temperatūra vagone $+26^{\circ} \mathrm{C}$. Žiemą, kai oro temperatūra ne žemesnè kaip $-40{ }^{\circ} \mathrm{C}$ ir kūrenama kietuoju kuru, $T_{U}=+22{ }^{\circ} \mathrm{C}$, o kai vanduo šildomas elektra $T_{U}=24{ }^{\circ} \mathrm{C}$ (automatiškai turi būti palaikoma $(22 \pm 2)^{\circ} \mathrm{C}$ temperatūra); $V$ - sąstato vagonų skaičius; $\bar{T}_{f}-c$-ojo vagono vidutinè vidaus oro temperatūra, išmatuota atskirose jo vietose $n_{T}$ kartų visame kelionès maršrute:

$$
\bar{T}_{f}=\frac{\sum_{t=1}^{n_{T}} T_{f t}}{n_{T}},
$$

čia: $T_{f t}-t$-ojo matavimo temperatūra, ${ }^{\circ} \mathrm{C} ; n_{T}-$ temperatūros matavimų skaičius $\left(t=1,2, \ldots, n_{T}\right)$.

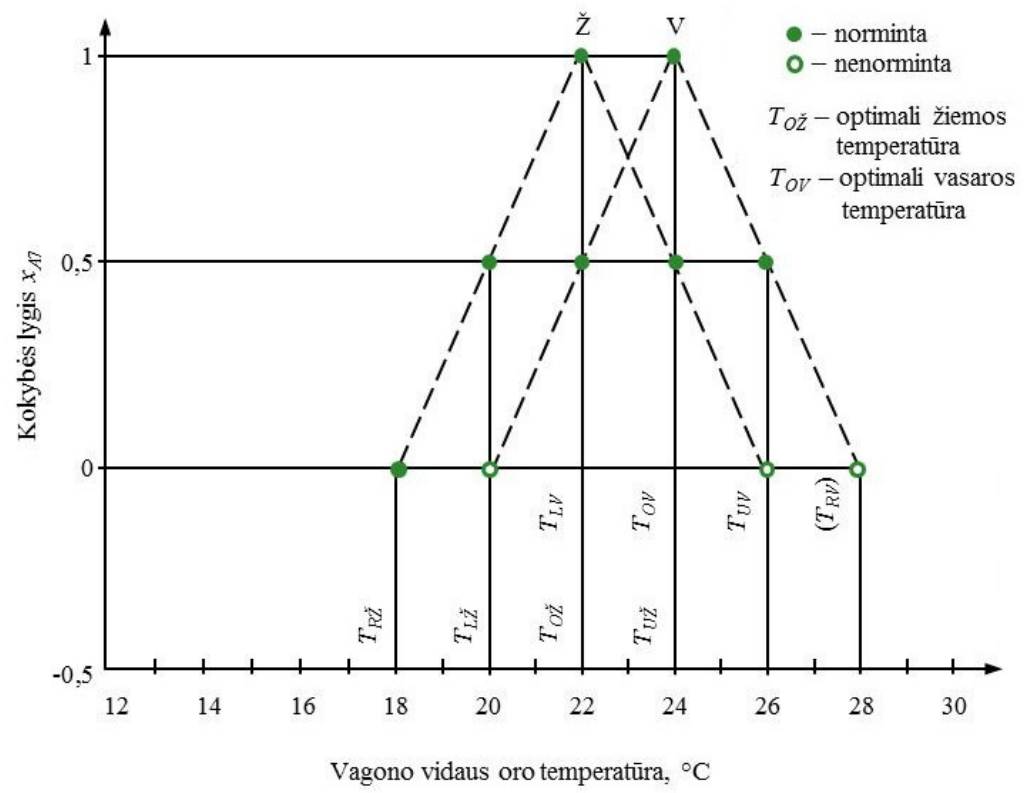

2.10 pav. Norminamos vagono temperatūros ir keleivių patogumo žiemos (kai aplinkos oro temperatūra ne žemesnè nei $-40^{\circ} \mathrm{C}$ ) ir vasaros (kai veikia oro kondicionierius) laikotarpiu sąsaja

Fig. 2.10. The relationship between the standardized temperature in a car and passenger comfort during winter (when the outdoor temperature is not lower than $-40{ }^{\circ} \mathrm{C}$ ) and summer (when air conditioning is on) 
Blogiausias variantas $\left(x_{A 7}=0\right)$ yra tada, kai $\bar{T}_{f}$ yra $2{ }^{\circ} \mathrm{C}$ žemesnè už apatinę leidžiamą ribą $T_{L}$ arba kai $\bar{T}_{f}$ yra $2{ }^{\circ} \mathrm{C}$ didesnè už viršutinę leidžiamą ribą $T_{U}$. Jeigu $\bar{T}_{f}$ daugiau negu $2{ }^{\circ} \mathrm{C}$ mažesnè už $T_{L}$ arba $2{ }^{\circ} \mathrm{C}$ didesnè už $T_{U}, x_{A 7}$ gaunamas neigiamas ir imamas lygus 0 .

8. Sanitarinių mazgų (tualetų) tipas (atviro tipo ar vakuuminis) ir būklè. Tolimojo ir vietinio susisiekimo keleiviniuose vagonuose turi būti irengti du uždaro tipo sanitariniai mazgai, o bagažo ir restorano vagonuose - viena tualeto patalpa. Sanitarinių mazgų (tualetų) tipui vertinti skiriami šie balai: 0 - vagone sanitariniai mazgai sugedę, 1 - vagone sanitariniai mazgai atviro tipo, tvarkingi, 2 - vagone vienas tualetas atviro tipo, kitas - vakuuminis, tvarkingi, 3 - sanitariniai mazgai uždaro tipo, netvarkingi, 4 - sanitariniai mazgai uždaro tipo, tvarkingi. KKVR $K_{A}$, ivvertinančio vagono sanitarinių mazgų itaką, dèmuo skaičiuojamas pagal šią formulę:

$$
x_{A 8}=\frac{\sum_{c=1}^{V}\left(\frac{W C_{f}}{W C_{\max }}\right)_{c}}{V},
$$

čia: $x_{A 8}$ - A grupès 8-ojo kriterijaus kintamasis dydis; $W C_{f}-c$-ojo vagono sanitarinių mazgų faktiškos būklès vertinimas balais ( 0 arba 4 balai); $W C_{\max }-$ didžiausias galimas $c$-ojo vagono sanitariniu mazgų ivertinimo balas (4 balai); $V$ - sąstato vagonų skaičius.

9. Gultų konstrukcija (viršutinių gultų saugos diržai), specialios priemonės neigaliesiems. Vagono gultų konstrukcijai (viršutinių gultų saugos diržams), specialiosioms priemonėms neigaliems keleiviams vertinti skiriami šie balai: 0 - viršutiniai gultai neturi saugos diržų (apsauginių laikiklių), vagonas nepritaikytas neigaliems keleiviams, 1 - viršutiniai gultai turi saugos diržus, tačiau vagonas nepritaikytas neigaliems keleiviams, 2 - viršutiniai gultai turi saugos diržus, vagonas pritaikytas neigaliesiems, 3 - vagone tik apatiniai gultai (saugos diržai nereikalingi), vagonas nepritaikytas neigaliesiems, 4 - vagone tik apatiniai gultai, vagonas pritaikytas neigaliesiems. KKVR $K_{A}$, ịvertinančio vagono gultų konstrukciją (viršutinių gultų saugos diržų buvimą), dèmuo skaičiuojamas pagal šią formulę:

$$
x_{A 9}=\frac{\sum_{c=1}^{V}\left(\frac{G_{f}}{G_{\max }}\right)_{c}}{V},
$$

čia: $x_{A 9}$ - A grupès 9-ojo kriterijaus kintamasis dydis; $G_{f}-c$-ojo vagono gultu konstrukcijos (viršutinių gultų saugos diržų buvimo) ir pritaikymo neigaliems keleiviams įvertinimas balais $\left(0,1,2,3\right.$ arba 4 balai); $G_{\max }$ - didžiausias galimas 
gultų konstrukcijos (viršutinių gultų saugos diržų buvimo) ir vagono pritaikymo neigaliems keleiviams įvertinimo balas (4 balai); $V$ - sąstato vagonų skaičius.

10. Irengtas nuolat veikiantis dušas. Dušo įrengimui vagone vertinti skiriami šie balai: 0 - vagone dušas neịrengtas, 1 - vagone įrengtas nustatytu laiku veikiantis dušas, 2 - vagone įrengtas nuolat veikiantis dušas. KKVR $K_{A}$, ivertinančio vagone veikiančio dušo įtaka, dèmuo skaičiuojamas pagal šią formulę:

$$
x_{A 10}=\frac{\sum_{c=1}^{V}\left(\frac{D_{f}}{D_{\max }}\right)_{c}}{V},
$$

čia: $x_{A 10}$ - A grupès 10 -ojo kriterijaus kintamasis dydis; $D_{f}-$ dušo buvimo ir jo darbo laiko įvertinimas $c$-ajame vagone balais ( 0,1 arba 2 balai); $D_{\max }-$ didžiausias galimas dušo buvimo ir jo darbo laiko įvertinimas balais (2 balai); $V$ - sąstato vagonų skaičius.

11. Specialios kupė dviračiams vežti. Irengti kiekviename vagone specialias kupe dviračiams vežti būtų neracionalu, todèl vertinant dviračių vežimo traukinyje sallygas, numatoma, kad traukinyje turi būti vienas vagonas arba atskira kupe, pritaikyti dviračiams vežti ir skiriami šie balai: 0 - traukinyje nèra vagono (kupè), pritaikyto dviračiams vežti, todèl vežtis dviratị yra draudžiama, 1 traukinyje nèra vagono (kupè), pritaikyto dviračiams vežti, už išardyto ir supakuoto dviračio vežimą reikia mokèti nustatytą mokesti, 2 - traukinyje nèra vagono (kupè), pritaikyto dviračiams vežti, už išardyto ir supakuoto dviračio vežimą mokèti nereikia, 3 - traukinyje yra vagonas (kupè), pritaikytas dviračiams vežti, už dviračio vežimą reikia mokèti nustatytą mokesti, 4 - traukinyje yra vagonas (kupè), pritaikytas dviračiams vežti, už dviračio vežimą mokèti nereikia. KKVR $K_{A}$, i̇vertinančio dviračio traukinyje vežimo galimybę ir sąlygas, dèmuo skaičiuojamas pagal šią formulę:

$$
x_{A 11}=\frac{D V_{f}}{D V_{\max }},
$$

čia: $x_{A 11}$ - A grupès 11-ojo kriterijaus kintamasis dydis; $D V_{f}$ - vagono (kupè), pritaikyto dviračiams vežti, traukinyje buvimas ir dviračio vežimo sąlygu ịvertinimas balais ( $0,1,2$ arba 4 balai); $D V_{\max }$ - didžiausias galimas vagono (kupè), pritaikyto dviračiams vežti, buvimo sąstate ir dviračių vežimo sąlygų ịvertinimas balais (4 balai).

12. Rūkyti skirtos vietos. Skiriami šie balai: 0 - traukinyje draudžiama rūkyti, 1 - traukinyje rūkoma tam skirtose vagonu angainèse, 2 - traukinyje yra vagonas, skirtas rūkantiesiems. KKVR $K_{A}$, ivvertinančio rūkyti skirtų vietų itaka, dėmuo skaičiuojamas pagal šią formulę: 


$$
x_{A 12}=\frac{R V_{f}}{R V_{\max }},
$$

čia: $x_{A 12}$ - A grupès 12-ojo kriterijaus kintamasis dydis; $R V_{f}$ - rūkymo vietų traukinyje įvertinimas balais ( 0,1 arba 2 balai); $R V_{\max }-$ didžiausias galimas rūkymo vietų traukinyje ivertinimo balas (2 balai).

13. Radijo mazgas ir jo centralizuotas ijungimas ir išjungimas. Radijo mazgas yra irengtas traukinio viršininko kupè. Traukiniui išvykus ir kelionès metu radijo ryšiu traukinio viršininkas privalo teikti keleiviams informaciją apie traukinio maršrutą, skelbti stočių pavadinimus (pasienio ir muitinès kontrolès stotis), atvykima i galinę stoti, informuoti apie traukinyje teikiamas paslaugas, traukiniui vèluojant ispèti keleivius apie sutrumpintą traukinio stovejjimo laiką, vèlavimo priežastis, supažindinti keleivius su elgesio ir priešgaisrinès saugos taisyklèmis, kuriu reikia laikytis kelioneje (Tarptautinio susisiekimo keleivinio traukinio... 2003). Traukinyje yra transliuojamos radijo laidos, populiariosios ir klasikinès muzikos kūriniai. Radijo mazgui ir jo centralizuotam ijungimui ir išjungimui vertinti skiriami šie balai: 0 - radijas vagone neveikia (traukinyje neirrengtas radijo mazgas, tarp vagonų nèra jungčių arba dèl gedimo), 1 - radijo ijungimas ir išjungimas vagone reguliuojamas jungikliu, kuris yra palydovo darbo kupè, 2 - radijo jjungimas ir išjungimas reguliuojamas jungikliais, kurie yra kiekvienoje vagono kupe, 3 - radijo ijungimas ir išjungimas reguliuojamas jungikliais, kurie yra kiekvienoje kupe ir koridoriuje (salone), 4 - kiekvienas keleivis, pageidaujantis klausytis radijo transliacijos, gali naudotis specialiomis ausinemis. KKVR $K_{A}$, ivertinančio radijo mazgo ir jo centralizuoto jjungimo ir išjungimo itaka, demuo skaičiuojamas pagal šią formulę:

$$
x_{A 13}=\frac{\sum_{c=1}^{V}\left(\frac{R M_{f}}{R M_{\max }}\right)_{c}}{V},
$$

čia: $x_{A 13}$ - A grupès 13-ojo kriterijaus kintamasis dydis; $R M_{f}$ - radijo veikimo ir jo centralizuoto jjungimo ir išjungimo $c$-ajame vagone ivertinimo balas $(0,1,2,3$ arba 4 balai); $R M_{\max }$ - didžiausias galimas radijo veikimo ir jo centralizuoto ijungimo ir išjungimo įvertinimo balas (4 balai); $V$ - sąstato vagonų skaičius.

14. Restorano vagonas. Restorano vagono buvimui traukinyje, aptarnavimui ir teikiamoms paslaugoms vertinti skiriami šie balai: 0 - traukinyje nèra restorano vagono, palydovai vagonuose taip pat keleiviams nieko nesiūlo, 1 - traukinyje nèra restorano vagono, palydovai keleiviams siūlo kavos, arbatos ir kt., 2 - restorano vagonas važiuoja tik savaitgaliais, tačiau jame neprekiaujama alkoholiniais gèrimais, nèra padavejjo, palydovai keleiviams taip pat nieko nesiūlo, 3 - restorano vagonas važiuoja tik savaitgaliais, jame neprekiaujama alkoholiniais gèrimais, 
nèra padavejjo, palydovai siūlo keleiviams kavos, arbatos ir kt., 4 - restorano vagonas važiuoja tik savaitgaliais, jame prekiaujama alkoholiniais gèrimais, yra padavejas, palydovai siūlo keleiviams kavos, arbatos ir kt., 5 - restorano vagonas važiuoja traukinyje nuolat, jame neprekiaujama alkoholiniais gèrimais, nèra padavejo, palydovai keleiviams nieko nesiūlo, 6 - restorano vagonas važiuoja traukinyje nuolat, jame neprekiaujama alkoholiniais gèrimais, nèra padavejo, palydovai siūlo keleiviams kavos, arbatos ir kt., 7 - restorano vagonas važiuoja traukinyje nuolat, jame prekiaujama alkoholiniais gèrimais, nèra padavejjo, palydovai siūlo keleiviams kavos, arbatos ir kt., 8 - restorano vagonas važiuoja traukinyje nuolat, jame prekiaujama alkoholiniais gèrimais, yra padavejjas, palydovai siūlo keleiviams kavos, arbatos ir konditerijos gaminių. KKVR $K_{A}$, ivvertinančio restorano vagono įtaka, dèmuo skaičiuojamas pagal šią formulę:

$$
x_{A 14}=\frac{V R_{f}}{V R_{\max }},
$$

čia: $x_{A 14}$ - A grupès 14-ojo kriterijaus kintamasis dydis; $V R_{f}$ - restorano vagono buvimo, aptarnavimo ịvertinimas balais $\left(0,1,2,3,4,5,6,7\right.$ arba 8 balai); $V R_{\max }-$ didžiausias galimas restorano vagono buvimo, aptarnavimo įvertinimo balas ( 8 balai).

15. Palydovo skubaus iškvietimo ị kupé galimybè. Važiuoti vagone, kuriame yra galimybė iškviesti palydovą neišeinant iš kupè, yra patogu, kai reikia ko nors paklausti ar paprašyti palydovo staiga pablogejus savijautai. Iškviesti palydovą galima paspaudus kupe esanti jungiklį. Palydovo skubaus iškvietimo i kupè galimybei vertinti skiriami šie balai: 0 - vagono kupé nèra irengto palydovo skubaus iškvietimo jungiklio, 1 - vagono kupe yra irengtas palydovo skubaus iškvietimo jungiklis, tačiau jis neveikia (pvz., tam, kad jis veiktų, reikalinga magnetine kortelè); 2 - vagono kupe yra irengtas veikiantis palydovo skubaus iškvietimo jungiklis. KKVR $K_{A}$, ivertinančio palydovo skubaus iškvietimo i kupé galimybę, dèmuo skaičiuojamas pagal šią formulę:

$$
x_{A 15}=\frac{\sum_{c=1}^{V}\left(\frac{P I_{f}}{P I_{\max }}\right)_{c}}{V},
$$

čia: $x_{A 15}$ - A grupès 15 -ojo kriterijaus kintamasis dydis; $P I_{f}$ - palydovo skubaus iškvietimo i kupe galimybès įvertinimas $c$-ajame vagone balais $(0,1$ arba 2 balai); $P I_{\max }$ - didžiausias palydovo skubaus iškvietimo ị kupè galimybès įvertinimo balas (2 balai); $V$ - sąstato vagonų skaičius.

16. Galimybè pasinaudoti plaukų džiovintuvu, drabužiu lygintuvu. Vertinant galimybę traukinyje pasinaudoti plaukų džiovintuvu, drabužių lygintuvu skiriami šie balai: 0 - traukinyje nèra galimybès naudotis plaukų džiovintuvu, 
drabužių lygintuvu, 1 - traukinyje galima naudotis savo plaukų džiovintuvu, tačiau nèra galimybès naudotis drabužiu lygintuvu, 2 - traukinyje yra ịengta buitinè kupè, kurioje yra plaukų džiovintuvas ir drabužių lygintuvas, kuriuos gali naudoti keleiviai už nustatytą mokesti, 3 - traukinyje yra įrengta buitinė kupè, kurioje yra plaukų džiovintuvas ir drabužių lygintuvas, kuriuos gali naudoti keleiviai nemokamai, 4 - traukinyje yra grožio salonas ir buitine kupé, kur pirmajame nemokamai kerpami plaukai, daromos šukuosenos, o antrajame skalbiami ir lyginami drabužiai. KKVR $K_{A}$, ivertinančio galimybę pasinaudoti plaukų džiovintuvu, drabužių lygintuvu, dèmuo skaičiuojamas pagal šią formulę:

$$
x_{A 16}=\frac{D L_{f}}{D L_{\max }},
$$

čia: $x_{A 16}$ - A grupès 16-ojo kriterijaus kintamasis dydis; $D L_{f}$ - galimybès pasinaudoti plaukų džiovintuvu, drabužių lygintuvu traukinyje ivertinimas balais $(0$, 1, 2, 3 arba 4 balai); $D L_{\max }$ - galimybès traukinyje pasinaudoti plaukų džiovintuvu, drabužių lygintuvu didžiausias įvertinimas balais (4 balai).

Kriteriju, susietu su traukinio elementais ir geležinkelio kelio technine būkle, daugiakriteris rodiklis $K_{A}$ skaičiuojamas pagal šią formulę:

$$
\begin{aligned}
& K_{A}=\bar{Z}_{A}^{*} \cdot\left(\bar{Q}_{A 1} \cdot \frac{\sum_{s=1}^{N_{k m}}\left(1-\frac{K K I_{f}^{2}}{K K I_{r i b}^{2}}\right)_{s}}{N_{k m}}+\bar{Q}_{A 2} \cdot \frac{\sum_{l=1}^{r}\left(1-\frac{\left|\Delta v_{f}\right|}{v_{\max , l}}\right) \cdot l_{l}}{\sum_{l=1}^{r} l_{l}}+\bar{Q}_{A 3} \cdot \frac{\sum_{c=1}^{V}\left(\frac{V K B_{f}}{V K B_{\max }}\right)_{c}}{V}+\right. \\
& \bar{Q}_{A 4} \cdot\left(1-\frac{\sum_{c=1}^{V}\left(\frac{T L_{f}}{T L_{\max }}\right)_{c}}{V}\right)+\bar{Q}_{A 5} \cdot \frac{\sum_{c=1}^{V}\left(\frac{I_{f}}{I_{\max }}\right)_{c}}{V}+\bar{Q}_{A 6} \cdot \frac{\sum_{c=1}^{V}\left(\frac{V K A_{f}}{V K A_{\max }}\right)_{c}}{V}+ \\
& \bar{Q}_{A 7} \cdot\left(1-\frac{\sum_{c=1}^{V}\left|\frac{\frac{T_{U}+T_{L}}{2}-\bar{T}_{f}}{T_{U}-T_{L}}\right|_{c}}{V}\right)+\bar{Q}_{A 8} \cdot \frac{\sum_{c=1}^{V}\left(\frac{W C_{f}}{W C_{\max }}\right)_{c}}{V}+\bar{Q}_{A 9} \cdot \frac{\sum_{c=1}^{V}\left(\frac{G_{f}}{G_{\max }}\right)_{c}}{V}+
\end{aligned}
$$




$$
\begin{aligned}
& \bar{Q}_{A 10} \cdot \frac{\sum_{c=1}^{V}\left(\frac{D_{f}}{F_{\max }}\right)_{c}}{V}+\bar{Q}_{A 11} \cdot \frac{D V_{f}}{D V_{\max }}+\bar{Q}_{A 12} \cdot \frac{R V_{f}}{R V_{\max }}+\bar{Q}_{A 13} \cdot \frac{\sum_{c=1}^{V}\left(\frac{R M_{f}}{R M_{\max }}\right)_{c}}{V}+ \\
& \left.\bar{Q}_{A 14} \cdot \frac{V R_{f}}{V R_{\max }}+\bar{Q}_{A 15} \cdot \frac{\sum_{c=1}^{V}\left(\frac{P I_{f}}{P I_{\max }}\right)_{c}}{V}+\bar{Q}_{A 16} \cdot \frac{D L_{f}}{D L_{\max }}\right)
\end{aligned}
$$

Naudojant eksperimentinių tyrimu duomenis ir kiekvieno kriterijaus kritines, leidžiamąsias ar geriausias vertes, iš šio modelio galima gauti A kriterijų grupès itaką TKVGK, išreikštą vienu parametru.

\subsubsection{Kriterijų, susietų su kelionès traukiniu proceso organizavimu ir technologija, vertinimo modelis}

Suformuluota ir pagrissta 19 kriterijų, susietų su kelionès traukiniu proceso organizavimu ir technologija (2.4 pav.), kurių KKVR $K_{B}$ dèmuo su iš ekspertinių tyrimų apskaičiuojamu vidutiniu svorio koeficientu $\bar{Z}_{B}^{*}$ ir kiekvieno kriterijaus svorio vidurkiu $\bar{Q}_{j}$ apskaičiuojamas pagal formulę:

$$
K_{B}=\bar{Z}_{B}^{*} \cdot\left(\bar{Q}_{B 1} \cdot x_{B 1}+\bar{Q}_{B 2} \cdot x_{B 2}+\ldots+\bar{Q}_{B 19} \cdot x_{B 19}\right),
$$

čia: $K_{B}$-tarptautinio traukinio $\operatorname{KKVR}\left(K_{B}\right.$ kinta nuo 0 iki 1$)$; $\bar{Z}_{B}^{*}-$ triju kategorijų $(\mathrm{K}, \mathrm{P}, \mathrm{A})$ respondentų ir ekspertų nuomonių apie B kriterijų grupés svarbą vidutinis svorio koeficientas; $\bar{Q}_{B 1}, \ldots, \bar{Q}_{B m}-\mathrm{B}$ kriteriju grupés $j$-ojo $(j=1,2, \ldots$, $m$ ) kriterijaus svorio vidurkis, nustatytas ekspertu metodu; $x_{B 1}, \ldots, x_{B m}-\mathrm{B}$ kriterijų grupès $j$-ojo $(j=1,2, \ldots, m)$ kriterijaus kintamasis dydis, iš kurio vertès apskaičiuojamas kriterijaus faktiškas lygmuo, kintantis nuo 0 iki 1 . Keleivių vežimo tarptautiniu traukiniu KKVR, ivertinančiam traukinio elementų kelionės proceso organizavimo ir technologijos ịtaką, apskaičiuoti, būtina apskaičiuoti kiekvieno kriterijaus kintamuosius dydžius $x_{B 1}, \ldots, x_{B 19}$.

1. Traukinių išvykimas ir atvykimas laiku. Traukinių eismas organizuojamas eismo grafiku, privalomu visų geležinkelio padalinių darbui. Jo laikymasis yra vienas iš svarbiausiu geležinkelio darbo kokybės rodiklių. Jei dèl technikos gedimo arba stichinių nelaimių buvo pažeistas traukinių eismo grafikas, visų tarnybų darbuotojai privalo imtis operatyvių priemonių, kad vèluojantys keleiviniai ir prekiniai traukiniai vèl važiuotų pagal grafiką, garantuojant jų saugų eismą (Techninio geležinkeliu... 1996). Traukinys turi atvykti laiku ne tik i galinę 
stotị, bet ir į tarpines stotis. Jeigu traukinys vèluoja iki 5 minučių, dar nerašomas aktas ir tarnybinis pranešimas, dèl to laikoma, kad toks vèlavimas yra leistinas. Kiekvieną stotelę grafiko požiūriu apibūdina galimi 4 grafiko laikymosi (kiekvienai stotelei) variantai ( 2.11 pav.):

a) traukinys i stoti atvyksta per anksti;

b) traukinys iš stoties išvyksta per anksti (kai dèl traukinio pavèluoto atvykimo i stoti trumpinamas stovejjimo laikas). Jis galimas, bet neleidžiamas;

c) traukinys i stoti vèluoja atvykti;

d) traukinys iš stoties išvyksta per vèlai.

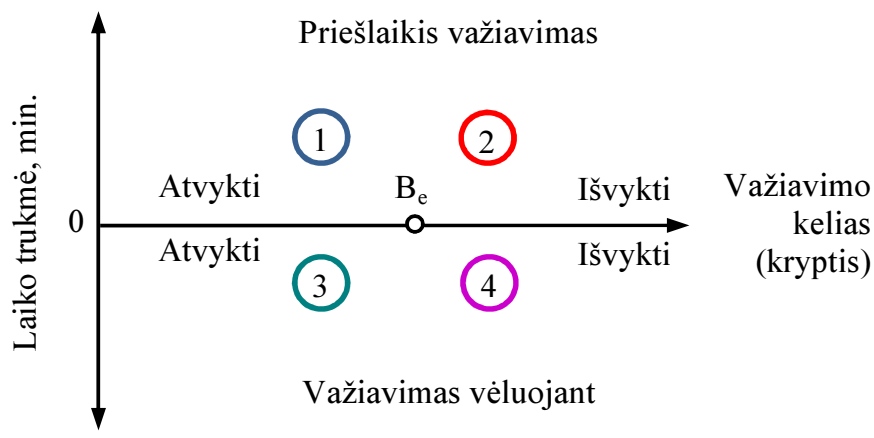

2.11 pav. Keleivinio traukinio laikymosi nustatyto tvarkaraščio $B$ tarpineje stotyje modelis

Fig. 2.11. The model of passenger train's keeping to schedule at the intermediate station $B$

Iš pradinès $A$ stoties traukinys anksčiau nei nurodyta važiavimo grafike išvykti negali, tačiau gali vẻluoti išvykti (2.12 pav). I galinę (paskirties) $C$ stoti, dèl įvairių kliūčių kelionès metu, traukinys gali atvykti vẻluodamas arba keletą minučių atvykti anksčiau. Galimi šie traukinio atvykimo į tarpinę stotị ir išvykimo iš jos grafiko požiūriu (2.13 pav.) deriniai:

- 1-2 atvyksta prieš laiką, išvyksta prieš laiką (neleidžiama);

- 1-4 atvyksta prieš laika, išvyksta vèluodamas;

- 3-4 atvyksta vèluodamas, išvyksta vẻluodamas;

- 3-2 atvyksta vèluodamas, išvyksta prieš laiką (neleidžiama).

Traukinio važiavimo visame maršrute (kelio ruože nuo išvykimo stoties iki atvykimo stoties) tvarkaraščio laikymosi ịvairūs galimi deriniai pavaizduoti 2.14 paveiksle. 

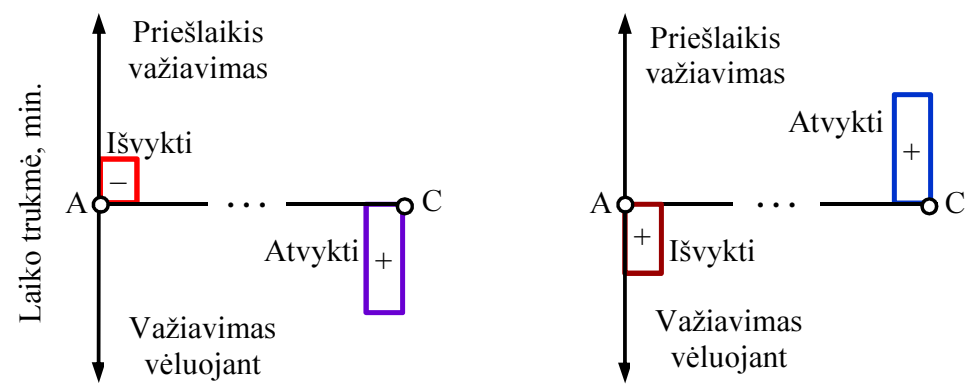

2.12 pav. Keleivinio traukinio laikymosi nustatyto tvarkaraščio išvykimo $A$ ir atvykimo $C$ stotyse modelis

Fig. 2.12. The model of passenger train's keeping to schedule, when departing from the station $A$ and arriving at the station $C$
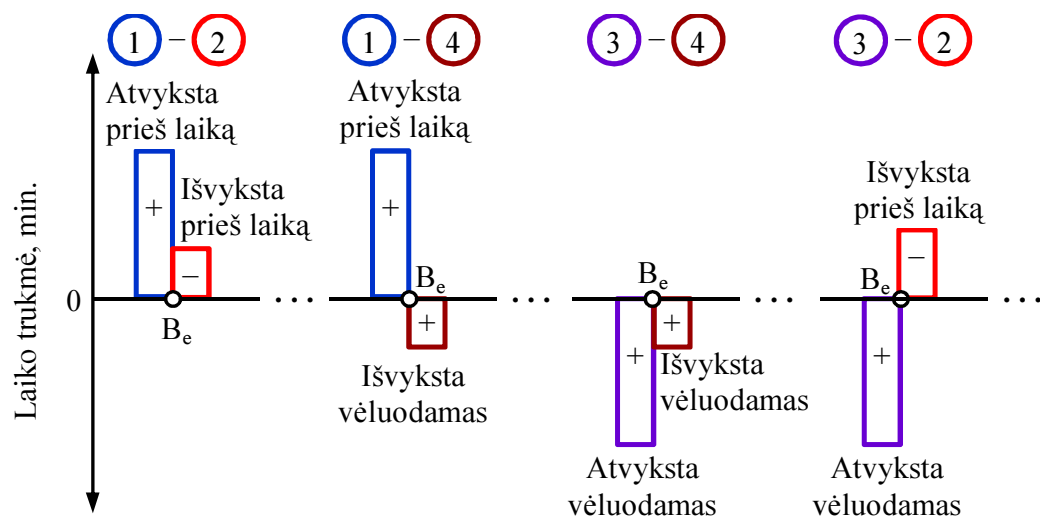

Derinių

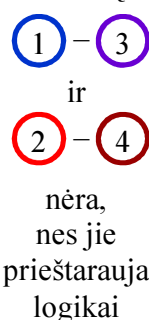

2.13. pav. Keleivinio traukinio atvykimo (išvykimo) prieš laiką (vèluojant) $B$ tarpineje stotyje dalinis derinys

Fig. 2.13. The combinations of passenger train's arrival (departure) at the intermediate station $B$ before (behind) schedule

Traukiniui vėluojant i galutini kelionès punktą nuo 60 iki 120 minučiuc, taip pat traukinio atšaukimo atveju keleivis gali reikalauti iš Vežejo kompensacijos, numatytos AB „Lietuvos geležinkeliai“ Bendrosiose keleivių vežimo taisyklèse (2011). Traukinio atvykimo ị stotị ir išvykimo iš stoties laiko itaką KKVR gali nustatyti traukinio viršininkas arba kitas asmuo (pvz., vyresnysis palydovas). 


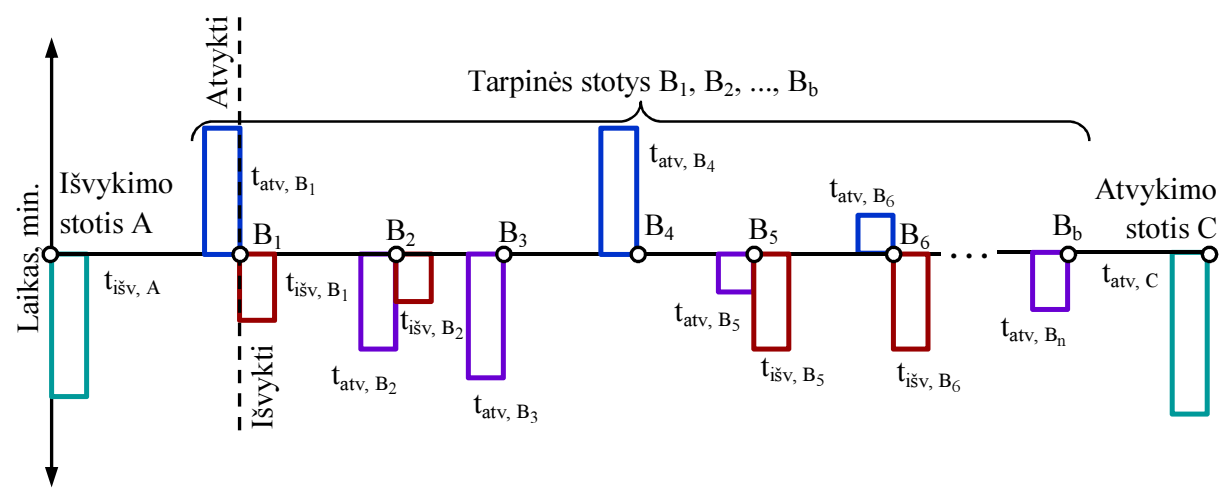

2.14 pav. Traukinio važiavimo visame maršrute (kelio ruože) tvarkaraščio laikymosi įvairūs galimi deriniai

Fig. 2.14. Various available combinations of train's keeping to schedule on the route

KKVR $K$ dėmens, priklausančio nuo kelionès traukiniu proceso organizavimo ir technologijos $K_{B}$, sandaugos $\bar{Q}_{B 1} \cdot x_{B 1}$, kintamojo dydžio $x_{B 1}$, rodančio traukinio atvykimo ir išvykimo laikų atitikti eismo grafikui, verte skaičiuojama pagal formulę:

$$
\begin{gathered}
\gamma \cdot\left(\left(t_{i \check{s v}, l}+t_{i \check{s} v, A}\right)^{2}-t_{i \check{s v}, l}^{2}+\left(t_{a t v, l}+t_{a t v, C}\right)^{2}-t_{a t v, l}^{2}\right)+ \\
x_{B 1}=1-\frac{+(1-\gamma) \cdot \sum_{e=1}^{b}\left(\left(t_{a t v, l}+t_{a t v, B}\right)^{2}-t_{a t v, l}^{2}+\left(t_{i \check{s} v, l}+t_{i \check{s}, B}\right)^{2}-t_{i \check{s}, l, l}^{2}\right)_{e}}{\beta(2+b) \cdot t_{a t v, l}^{2}},
\end{gathered}
$$

čia: $t_{i \check{s} v, A}$ - vèlavimo išvykti iš išvykimo stoties $A$ laikas, min.; $t_{a t v, C}$ - vèlavimo atvykti $i$ atvykimo (galinę) stotị $C$ laikas, min.; $t_{a t v, B}$ - vèlavimo atvykti $\mathfrak{i}$ tarpinę stoti $e$ laikas, min.; $t_{i \check{v} v, B}-$ vèlavimo išvykti iš tarpinès stoties $e$ laikas, min.; $t_{a v, l}=$ $t_{i \breve{v}, l}$ - vélavimo atvykti (išvykti) $\mathfrak{i}$ / iš išvykimo, atvykimo ar tarpinę stotị tolerancija (imama 5 min., nes tiek traukiniui vèluojant nereikia rašyti akto, tarnybinio pranešimo); $b$-tarpinių stočių reise (maršrute) skaičius, $e=1,2, \ldots, b ; \beta-$ koeficientas, priklausantis nuo maršruto tarpinių stočiu skaičiaus; $\gamma$ - vèlavimo išvykti iš išvykimo (pradinès) $A$ ir atvykti i galinę $C$ stotị svorio koeficientas, priklausantis nuo pradineje stotyje $A$ ịlipančiu ir galinèje stotyje $C$ išlipančiu keleivių skaičiaus santykio su visų reise važiavusių keleivių skaičiumi: gaunamas pradinejje (išvykimo) stotyje ilaipintų ir važiuojančių iki galinès (atvykimo) 
stoties keleivių skaičių $N_{A+C}$ padalijus iš visų (ilipusių pradinèje ir tarpinèse stotyse ir išlipusiu tarpinèse bei galinèje (atvykimo) stotyje) reise (maršrute) važiavusių keleivių skaičiaus (ne įlipimo ir išlipimo atvejų skaičius) $N_{\text {reiso }}$, t. y.:

$$
\gamma=\frac{N_{A+C}}{N_{\text {reiso }}} .
$$

Didejjant tarpinių stočiu skaičiui, $\beta$ mažèja pagal eksponentinę priklausomybę (2.15 pav.). $\beta$ koeficientas turi būti skaičiuojamas taip, kad jo vertè leistų turèti vidutini keleivių vežimo kokybès lygi pagal $x_{B 1}$ kriterijaus kintamają dali. 2.15 paveiksle pavaizduotas atvejis, kai $\gamma=1$, t. y. visi keleiviai važiuoja nuo pradinès stoties iki paskirties (galinès) stoties.

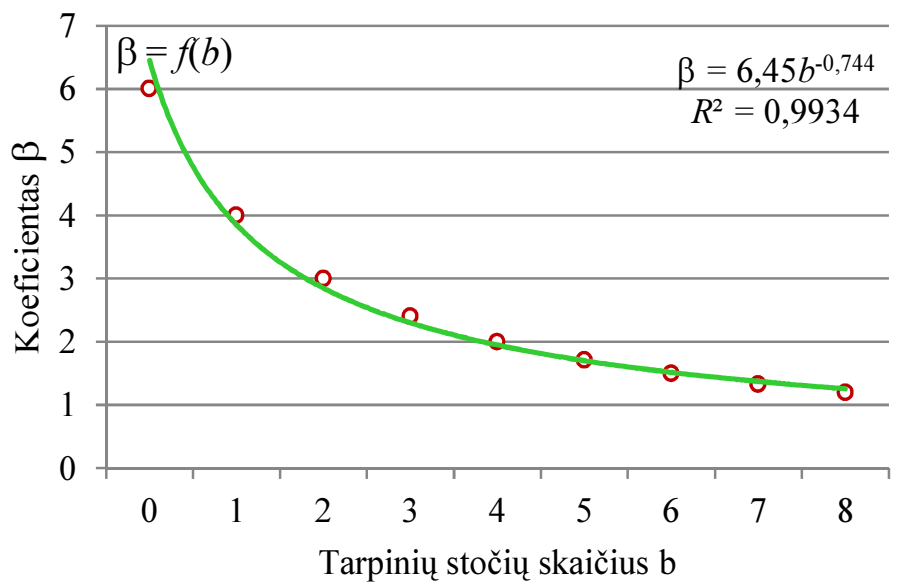

2.15 pav. Koeficiento $\beta$ priklausomybè nuo maršruto tarpinių stočių skaičiaus Fig. 2.15. The dependence of the coefficient on the number of intermediate stations on the route

Koeficiento $\beta$ skaičiavimo rezultatai, kai maršrute yra tam tikras tarpinių stočių skaičius ir $\gamma=1$, pateikti 2.3 lentelejje.

2.3. lentelè. Koeficiento $\beta$ skaičiavimo rezultatai, kai maršrute yra tam tikras tarpiniu stočiu skaičius ir $\gamma=1$ (gaunama vidutinè maršruto kokybè)

Table. 2.3. The results of calculating the coefficient $b$, when there is a certain number of intermediate stations on the route and $\gamma=1$ (the average route quality is obtained)

\begin{tabular}{|l|c|c|c|c|c|c|c|c|c|}
\hline Tarpinių stočių skaičius & 0 & 1 & 2 & 3 & 4 & 5 & 6 & 7 & 8 \\
\hline Koeficientas $\beta$ & 6 & 4 & 3 & 2,4 & 2 & 1,71 & 1,5 & 1,33 & 1,2 \\
\hline
\end{tabular}


2. Maisto davinio keleiviams pateikimas už ị bilietą ịskaičiuotą kainą. Skiriami šie balai: 0 - $\mathfrak{i}$ šio vagono bilieto kainą maisto davinys neịskaičiuotas, todèl keleiviams nepateikiamas, 1 - i šio vagono bilieto kainą maisto davinys iskaičiuotas ir keleiviams pateikiamas, 2 - maisto davinys keleiviams duodamas nemokamai. KKVR $K_{B}$, ivertinančio maisto davinio keleiviams pateikimą už i bilietą ịskaičiuotą kainą, dèmuo skaičiuojamas pagal šią formulę:

$$
x_{B 2}=\frac{\sum_{c=1}^{V}\left(\frac{M D_{f}}{M D_{\max }}\right)_{c}}{V},
$$

čia: $x_{B 2}-\mathrm{B}$ grupès 2-ojo kriterijaus kintamasis dydis; $M D_{f}-$ maisto davinio pateikimo arba nepateikimo už i bilietą įskaičiuotą (neịskaičiuota) kainą c-ajame vagone faktiškas ivvertinimas balais $\left(0,1\right.$ arba 2 balai); $M D_{\max }$ - didžiausias galimas maisto davinio pateikimo už i bilietą iskaičiuotą kainą ịvertinimo balas (2 balai); $V$ - sąstato vagonų skaičius.

3. Patalynès pateikimas, paklojimas ir jos būklè. Skiriami šie balai: 0 - patalynès vagone nèra, keleivis privalo vežtis savo patalynę, 1 - patalynė vagone nesupakuota ì specialią pakuotę, todèl nèra garantijos, kad nenaudota, už ją reikia sumokèti grynaisiais pinigais, palydovas neprivalo jos pakloti, 2 - patalynè vagone supakuota, todèl yra garantija, kad nenaudota (švari, išlyginta), už ją reikia sumokèti grynaisiais pinigais, palydovas neprivalo jos pakloti, 3 - patalynè vagone supakuota, pateikiama už i bilietą iskaičiuotą kainą, palydovas neprivalo jos pakloti, 4 - patalynè vagone supakuota, pateikiama už i bilietą iskaičiuotą kaina, palydovas privalo keleiviui pageidaujant ją pakloti, 5 - patalynè vagone pateikiama už i bilietą îskaičiuotą kaina, apatiniai gultai pakloti (patalynès švara abejotina), keleiviui pageidaujant palydovas privalo pakloti viršutinius gultus, 6 - patalynè vagone pateikiama už i bilietą iskaičiuotą kaina, apatiniai gultai pakloti (patalynė švari, išlyginta), keleiviui pageidaujant palydovas privalo pakloti viršutinius gultus, 7 - patalynè vagone pateikiama už i bilietą ịskaičiuotą kainą, apatiniai ir viršutiniai gultai pakloti (patalynès švara abejotina), 8 - patalynė vagone pateikiama už i bilietą ịskaičiuotą kaina, apatiniai ir viršutiniai gultai pakloti (patalynė švari, išlyginta), 9 - patalynè vagone pateikiama už i bilietą ịskaičiuotą kaina, vagone yra tik apatiniai gultai ir jie pakloti (patalynès švara abejotina), 10 - patalynė vagone pateikiama už i bilietą iskaičiuotą kaina, vagone yra tik apatiniai gultai ir jie pakloti (patalynès būkle puiki). KKVR $K_{B}$, ivvertinančio patalynès pateikimą, paklojimą ir jos būklę, demuo skaičiuojamas pagal šią formulę:

$$
x_{B 3}=\frac{\sum_{c=1}^{V}\left(\frac{P_{f}}{P_{\max }}\right)_{c}}{V},
$$


čia: $x_{B 3}-$ B grupès 3-ojo kriterijaus kintamasis dydis; $P_{f}$ - faktiškas patalynès paklojimo, pateikimo ir jos būklès ịvertinimas balais $(0,1,2,3,4,5,6,7,8,9$ arba 10 balų); $P_{\max }$ - didžiausias galimas ịvertinimo balas (10 balų).

4. Maisto ir gèrimų užsakymo iš restorano vagono ir atnešimo i kupé galimybe (per vagono palydova). Skiriami šie balai: 0 - tokios paslaugos traukinyje nèra, keleivis privalo pats nueiti į restorana, 1 - iš restorano užsakyti maisto ir gèrimų gali tik kai kurių kategorijų vagonu keleiviai, 2 - iš restorano užsakyti maisto ir gèrimų gali visų kategorijų vagonų keleiviai. KKVR $K_{B}$, ivertinančio maisto ir gèrimų užsakymo iš restorano vagono ir atnešimo į kupe galimybę (per vagono palydova), dėmuo skaičiuojamas pagal formulę:

$$
x_{B 4}=\frac{M U_{f}}{M U_{\max }},
$$

čia: $x_{B 4}$ - B grupès 4-ojo kriterijaus kintamasis dydis; $M U_{f}$ - faktiškas maisto ir gérimų užsakymo iš restorano vagono ir atnešimo i kupé galimybès (per vagono palydova) ivertinimas balais $(0,1$ arba 2$) ; M U_{\max }$ - didžiausias galimas maisto ir gérimų užsakymo iš restorano vagono ir atnešimo i kupe galimybès ịvertinimas balais ( 2 balai).

5. Spaudos platinimas traukinyje. Skiriami šie balai: 0 - traukinyje spaudos nèra, 1 - traukinyje spauda yra mokama, 2 - traukinyje kai kurie dienraščiai yra mokami, kai kurie nemokami, 3 - traukinyje visa spauda yra nemokama, tačiau mažas pasirinkimas, 4 - traukinyje visa spauda yra nemokama, didelis dienraščių ir žurnalų pasirinkimas. KKVR $K_{B}$, ivertinančio spaudos platinimą traukinyje, dèmuo skaičiuojamas pagal šią formulę:

$$
x_{B 5}=\frac{S P_{f}}{S P_{\max }},
$$

čia: $x_{B 5}-$ B grupès 5-ojo kriterijaus kintamasis dydis; $S P_{f}$ - faktiškas spaudos platinimo traukinyje įvertinimas balais $\left(0,1,2,3\right.$ arba 4 balai); $S P_{\max }-$ didžiausias galimas ivertinimas balais (4 balai).

6. Prieiga prie interneto. Galimybè naršyti internete važiuojant traukiniu viena aktualiausių temų pasaulio geležinkelių padangejje. Vis daugiau geležinkelių bendrovių, ypač aptarnaujančių priemiestinius maršrutus, teikia nemokamo bevielio ryšio (WiFi) paslaugas, taip ne tik pritraukdamos daugiau keleiviu, bet ir išlaikydamos šypsenas keliaujančiujų veiduose. Technologijų efektyvumas, ryšio naudojimo etiketo viešojoje erdvejje problemos dažnai sulètina arba sustabdo panašių projektų igyvendinimą. Pavyzdžiui, Londono metro žlugo visi ligšioliniai bandymai instaliuoti WiFi siųstuvus ir mobiliujų technologijų vartotojai negali jomis naudotis, nors neretai požeminiame traukinyje jie praleidžia valandą ir daugiau. Dauguma londoniečių važiuodami metro nenorètų klausytis mobiliujų telefonų 
melodijų, o ginču ar pasitarimų tuo labiau (Geležinkelininkas 2011 m. birželio 115 d., Nr. 11 (433). Prieigai prie interneto traukinyje vertinti skiriami šie balai: 0 traukinyje nèra prieigos prie interneto, 1 - traukinyje yra mokama prieiga prie interneto, 2 - traukinyje yra nemokama prieiga prie interneto. KKVR $K_{B}$, ivertinančio prieigos prie interneto traukinyje buvima, dèmuo skaičiuojamas pagal formulę:

$$
x_{B 6}=\frac{I P_{f}}{I P_{\max }},
$$

čia: $x_{B 6}-\mathrm{B}$ grupès 6-ojo kriterijaus kintamasis dydis; $I P_{f}$ - faktiškas prieigos prie interneto ivertinimas balais $\left(0,1\right.$ arba 2 balai); $I P_{\max }$ - didžiausias galimas ivertinimas balais ( 2 balai).

7. Kelionès bilieto pirkimo traukinyje galimybè (iš traukinio viršininko). Skiriami šie balai: 0 - traukinyje nèra galimybès pirkti bilietą iš traukinio viršininko, 1 - traukinyje yra galimybe pirkti bilietą iš traukinio viršininko i kai kurių kategorijų vagonus, 2 - traukinyje yra galimybe pirkti bilietą $i$ visų kategorijų vagonus. KKVR $K_{B}$, ivertinančio galimybę pirkti bilietą iš traukinio viršininko, dèmuo skaičiuojamas pagal šią formulę:

$$
x_{B 7}=\frac{B P_{f}}{B P_{\max }},
$$

čia: $x_{B 7}-\mathrm{B}$ grupès 7-ojo kriterijaus kintamasis dydis; $B P_{f}$ - faktiškas galimybès pirkti bilietą iš traukinio viršininko ịvertinimas balais $\left(0,1\right.$ arba 2 balai); $B P_{\max }-$ didžiausias galimas šios galimybès įvertinimas balais (2 balai).

8. Vietų restorano vagone rezervavimo galimybè. Skiriami šie balai: $0-$ traukinio restorano vagone vietos nerezervuojamos, 1 - traukinio restorano vagone vietos rezervuojamos kai kurių kategorijų vagonų keleiviams, 2 - traukinio restorano vagone vietos rezervuojamos visų kategorijų vagonų keleiviams. KKVR $K_{B}$, ivertinančio galimybę keleiviui rezervuoti vietą restorano vagone, dèmuo skaičiuojamas pagal šią formulę:

$$
x_{B 8}=\frac{V R R_{f}}{V R R_{\max }},
$$

čia: $x_{B 8}$ - B grupès 8-ojo kriterijaus kintamasis dydis; $V R R_{f}$ - faktiškas vietų restorano vagone rezervavimo galimybès ivertinimas balais $(0,1$ arba 2 balai); $V R R_{\max }$ - didžiausias galimas vietų restorano vagone rezervavimo galimybès ivertinimas balais ( 2 balai).

9. Taksi iškvietimo paslauga. Skiriami šie balai: 0 - traukinyje nèra taksi paslaugos užsakymo, 1 - traukinyje yra taksi paslaugos užsakymas i galinę (traukinio formavimo) stoti, bet ši paslauga mokama, 2 - traukinyje yra taksi paslaugos 
užsakymas i galinę (traukinio formavimo) stotị, ši paslauga nemokama, 3 - traukinyje yra taksi paslaugos užsakymas i galinę (traukinio formavimo arba paskirties) stotị, bet ši paslauga mokama, 4 - traukinyje yra taksi paslaugos užsakymas i galinę (traukinio formavimo arba paskirties) stoti, ši paslauga nemokama, 5 traukinyje yra taksi paslaugos užsakymas i visas stotis (kuriose stoja traukinys), bet ši paslauga mokama, 6 - traukinyje yra taksi paslaugos užsakymas i visas stotis (kuriose stoja traukinys), ši paslauga nemokama. KKVR $K_{B}$, ivertinančio taksi paslaugos užsakymo traukinyje galimybę, dėmuo skaičiuojamas pagal formulę:

$$
x_{B 9}=\frac{T I_{f}}{T I_{\max }},
$$

čia: $x_{B 9}$ - B grupès 9-ojo kriterijaus kintamasis dydis; $T I_{f}$ - faktiškas taksi paslaugos užsakymo įvertinimas balais $\left(0,1,2,3,4,5\right.$ arba 6 balai); $T I_{\max }-$ didžiausias galimas taksi paslaugos užsakymo ịvertinimas balais ( 6 balai).

10. Galimybè traukinyje atsiskaityti mokejjimo kortele. Skiriami šie balai: 0 traukinyje nèra galimybès atsiskaityti mokejjimo kortele, 1 - traukinyje yra galimybè atsiskaityti mokejjimo kortele, tačiau keleivis privalo nueiti į restorano vagona, kuriame yra irengtas elektroninis mokejimo korteliu skaitytuvas (EKS), 2 - traukinyje yra tokia galimybè, EKS yra irengtas kiekviename vagone. KKVR $K_{B}$, îvertinančio šią galimybę, dèmuo skaičiuojamas pagal šią formulę:

$$
x_{B 10}=\frac{M K_{f}}{M K_{\max }},
$$

čia: $x_{B 10}$ - B grupès 10-ojo kriterijaus kintamasis dydis; $M K_{f}$ - faktiškas galimybès traukinyje atsiskaityti mokejjimo kortele ivertinimas balais $(0,1$ arba 2 balai); $M K_{\max }$ - didžiausias galimas šios galimybès įvertinimas balais ( 2 balai).

11. Prekyba suvenyrais traukinyje. Prekybai suvenyrais traukinyje vertinti skiriami šie balai: 0 - traukinyje neprekiaujama suvenyrais, 1 - traukinyje prekiaujama suvenyrais, 2 - traukinyje suvenyrai keleiviams duodami nemokamai. $\mathrm{KKVR} K_{B}$, ivertinančio prekybą suvenyrais traukinyje, dèmuo skaičiuojamas pagal šią formulę:

$$
x_{B 11}=\frac{P S_{f}}{P S_{\max }},
$$

čia: $x_{B 11}$ - B grupès 11-ojo kriterijaus kintamasis dydis; $P S_{f}-$ faktiškas prekybos suvenyrais traukinyje ivertinimas balais $\left(0,1\right.$ arba 2 balai); $P S_{\max }-$ didžiausias galimas ivvertinimas balais ( 2 balai).

12. Traukinyje transliuojamų muzikos kūrinių, informacijos atitiktis keleivių norams. Vertinant tai, būtina atsižvelgti i keleivių nuomonę. Tam tikslinga rengti keleivių apklausas. Parengta tyrimo anketa (A priedas), kurioje vertindamas keleivis 
privalo skirti šiuos balus: 0 - labai blogai, 1 - blogai, 2 - patenkinamai, 3 - labai gerai, 4 - puiku. KKVR $K_{B}$, ivvertinančio traukinyje transliuojamų muzikos kūrinių, informacijos atitiktị keleivių norams, dèmuo skaičiuojamas pagal šią formulę:

$$
x_{B 12}=\frac{\sum_{k=1}^{n_{K}}\left(\frac{T M K_{f}}{T M K_{\max }}\right)_{k}}{n_{K}},
$$

čia: $x_{B 12}-\mathrm{B}$ grupès 12-ojo kriterijaus kintamasis dydis; $T M K_{f}-k$-ojo keleivio faktiškas traukinyje transliuojamų muzikos kūrinių, informacijos atitikties keleivių norams įvertinimas balais $\left(0,1,2,3\right.$ arba 4 balai); $T M K_{\max }$ - didžiausias galimas ịvertinimas balais (4 balai); $n_{K}$ - keleivių, ivvertinusių traukinyje transliuojamų muzikos kūrinių, informacijos atitiktị keleivių norams tam tikru balu, skaičius $\left(k=1,2, \ldots, n_{K}\right)$.

13. Keleivio bagažo ir daiktų apsauga. Skiriami šie balai: 0 - traukinyje keleivio bagažas, dokumentai ir kiti daiktai nèra saugomi, už jų saugumą atsako pats keleivis, 1 - traukinyje keleivio bagažas nesaugomas, dokumentai ir vertingi daiktai yra saugomi už nustatytą mokesti, 2 - traukinyje keleivio bagažas nesaugomas, dokumentai ir vertingi daiktai yra saugomi nemokamai, 3 - traukinyje už nustatytą mokesti yra saugomas keleivio bagažas, dokumentai ir kiti daiktai, 4 - traukinyje bagažui vežti skirtos vietos yra rakinamos, todèl keleivių bagažas ir kiti daiktai yra saugūs. KKVR $K_{B}$, ivvertinančio keleivio bagažo ir daiktų apsauga, dėmuo skaičiuojamas pagal šią formulę:

$$
x_{B 13}=\frac{B A_{f}}{B A_{\max }},
$$

čia: $x_{B 13}-$ B grupès 13-ojo kriterijaus kintamasis dydis; $B A_{f}$ - faktiškas keleivio bagažo ir daiktų apsaugos ịvertinimas balais ( $0,1,2,3$ arba 4 balai); $B A_{\max }-$ didžiausias galimas įvertinimas balais (4 balai).

14. Užsienio medicininių išlaidų draudimo ịsigijimo traukinyje galimybė. Skiriami šie balai: 0 - traukinyje nèra galimybès įsigyti užsienio medicininių išlaidų draudimo, 1 - traukinyje yra galimybe ịsigyti užsienio medicininių išlaidų draudimą, 2 - traukinyje įsigyti ši draudimą nèra poreikio, nes ị užsienị ketinantis keliauti asmuo yra draudžiamas vizos išdavimo metu. KKVR $K_{B}$, ivvertinančio galimybę traukinyje issigyti užsienio medicininių išlaidų draudimą, dèmuo skaičiuojamas pagal formulę:

$$
x_{B 14}=\frac{M I D_{f}}{M I D_{\max }},
$$


čia: $x_{B 14}-B$ grupès 14-ojo kriterijaus kintamasis dydis; $M I D_{f}$ - faktiškas galimybès traukinyje įsigyti užsienio medicininių išlaidų draudimą vertinimas balais $\left(0,1\right.$ arba 2 balai); $M I D_{\max }$ - didžiausias galimas galimybès traukinyje įsigyti užsienio medicininių išlaidų draudimą ịvertinimas balais ( 2 balai).

15. Vizos įsigijimo pasienio punkte galimybè. Skiriami šie balai: 0 - nèra galimybès įsigyti vizos pasienio punkte, 1 - yra galimybè ịsigyti vizą pasienio punkte, tačiau keleivis privalo nutraukti kelionę ir gavęs vizą važiuoti kitu traukiniu, 2 - yra galimybè i̇sigyti vizą pasienio punkte ir tęsti kelionę tuo pačiu traukiniu. KKVR $K_{B}$, ivvertinančio vizos įsigijimo pasienio punkte galimybę, dèmuo skaičiuojamas pagal šią formulę:

$$
x_{B 15}=\frac{I V_{f}}{I V_{\max }},
$$

čia: $x_{B 15}-\mathrm{B}$ grupès 15 -ojo kriterijaus kintamasis dydis; $I V_{f}$ - faktiškas vizos ịsigijimo pasienio punkte galimybès vertinimas balais $\left(0,1\right.$ arba 2 balai); $I V_{\max }-$ didžiausias galimas vizos įsigijimo pasienio punkte galimybès vertinimas balais ( 2 balai).

16. Aptarnaujančio personalo išvaizda (uniformos apranga, avalynè, šukuosena, vardinè kortelè). Vertinant aptarnaujančio personalo išvaizdą, būtina atsižvelgti i keleivių nuomonę. Parengta tyrimo anketa (A priedas), kurioje vertindamas aptarnaujančio personalo išvaizdą keleivis turi skirti šiuos balus: 0 - labai blogai, 1 - blogai, 2 - patenkinamai, 3 - labai gerai, 4 - puiku. KKVR $K_{B}$, ivertinančio aptarnaujančio personalo išvaizda, demuo skaičiuojamas pagal šią formulę:

$$
x_{B 16}=\frac{\sum_{k=1}^{n_{K}}\left(\frac{A P I_{f}}{A P I_{\max }}\right)_{k}}{n_{K}},
$$

čia: $x_{B 16}-\mathrm{B}$ grupès 16 -ojo kriterijaus kintamasis dydis; $A P I_{f}-k$-ojo keleivio faktiškas aptarnaujančio personalo išvaizdos ivvertinimas balais $(0,1,2,3$ arba 4 balai); $A P I_{\max }$ - didžiausias galimas ivvertinimas balais (4 balai); $n_{K}$ - keleivių ivertinusių aptarnaujančio personalo išvaizdą tam tikru balu, skaičius $\left(k=1,2, \ldots, n_{K}\right)$.

17. Aptarnaujančio personalo bendravimo su keleiviais ir tarpusavyje kultūra. Aptarnaudamas keleivius, palydovas privalo laikytis šių bendravimo su keleiviais taisyklių: keleivị būtina maloniai, draugiškai sutikti, atidžiai išklausyti, atsakyti i klausimus, būti mandagiam, taktiškam, pagarbiam. Su keleiviais kalbèti ramiai, santūriai, mintis reikšti trumpai ir aiškiai (Keleivinio vagono palydovo... 1999). Nereikšti paniekos kolegoms, pavaldiniams, vadovams, neižeidinėti jų, nevartoti keiksmažodžių, netinkamų posakių ( $A B$,,Lietuvos geležinkeliai" darbuotoju... 2008). Vertinant aptarnaujančio personalo bendravimo su 
keleiviais ir tarpusavyje kultūra, būtina atsižvelgti į keleivių nuomonę. Parengta tyrimo anketa (A priedas), kurioje vertindami aptarnaujančio personalo bendravimo su keleiviais ir tarpusavyje kultūrą keleiviai skiria šiuos balus: 0 - labai blogai, 1 - blogai, 2 - patenkinamai, 3 - labai gerai, 4 - puiku. KKVR $K_{B}$, ivertinančio aptarnaujančio personalo bendravimo su keleiviais ir tarpusavyje kultūra, dèmuo skaičiuojamas pagal šią formulę:

$$
x_{B 17}=\frac{\sum_{k=1}^{n_{K}}\left(\frac{A P B_{f}}{A P B_{\max }}\right)_{k}}{n_{K}},
$$

čia: $x_{B 17}-\mathrm{B}$ grupès 17 -ojo kriterijaus kintamasis dydis; $A P B_{f}-k$-ojo keleivio, faktiškas aptarnaujančio personalo bendravimo su keleiviais ir tarpusavyje kultūros ivertinimas balais $\left(0,1,2,3\right.$ arba 4 balai); $A P B_{\max }$ - didžiausias galimas ivertinimas balais (4 balai); $n_{K}$ - keleivių ivvertinusių aptarnaujančio personalo bendravimo su keleiviais ir tarpusavyje kultūrą tam tikru balu, skaičius $\left(k=1,2, \ldots, n_{K}\right)$.

18. Aptarnaujančio personalo užsienio kalbos mokejjimas. Skiriami šie balai: 0 - nemoka nei vienos užsienio kalbos, 1 - moka (gali susikalbèti) vieną užsienio kalba, 2 - moka (gali susikalbèti) dvi užsienio kalbas, 3 - moka (gali susikalbėti) tris užsienio kalbas, 4 - moka (gali susikalbèti) keturias ir daugiau užsienio kalbų. KKVR $K_{B}$, ivvertinančio aptarnaujančio personalo užsienio kalbos mokejima, dèmuo skaičiuojamas pagal formulę:

$$
x_{B 18}=\frac{\sum_{p=1}^{n_{P}}\left(\frac{U K_{f}}{U K_{\max }}\right)_{p}}{n_{P}},
$$

čia: $x_{B 18}-\mathrm{B}$ grupès 18 -ojo kriterijaus kintamasis dydis; $U K_{f}-p$-ojo traukini aptarnaujančio darbuotojo faktiškas užsienio kalbos mokejjimo vertinimas balais $\left(0,1,2,3\right.$ arba 4 balai); $U K_{\max }$ - didžiausias galimas užsienio kalbos mokejjimo ivertinimas balais (4 balai); $n_{P}$ - apklaustu traukinį aptarnaujančių darbuotojų skaičius $\left(p=1,2, \ldots, n_{P}\right)$.

19. Muitinès ir pasienio pareigūnų kompetencija, objektyvumas ir bendravimo su keleiviais kultūra. Jie pirmieji reprezentuoja savo šali, privalo atsakyti i keleiviams rūpimus klausimus (būti kompetentingi), būti mandagūs, taktiški, pagarbūs. Vertinant muitinès ir pasienio pareigūnų kompetencija, objektyvumą ir bendravimo kultūrą su keleiviais privaloma atsižvelgti i keleivių nuomonę (A priedas): 0 - labai blogai, 1 - blogai, 2 - patenkinamai, 3 - labai gerai, 4 - puiku. KKVR $K_{B}$, ivvertinančio muitinès ir pasienio pareigūnų kompetencija, objektyvumą ir bendravimo su keleiviais kultūrą, dėmuo skaičiuojamas pagal formulę: 


$$
x_{B 19}=\frac{\sum_{k=1}^{n_{K}}\left(\frac{M P K_{f}}{M P K_{\max }}\right)_{k}}{n_{K}},
$$

čia: $x_{B 19}-\mathrm{B}$ grupès 19 -ojo kriterijaus kintamasis dydis; $M P K_{f}-k$-ojo keleivio faktiškas muitinès ir pasienio pareigūnų kompetencijos, objektyvumo ir bendravimo su keleiviais kultūros vertinimas balais $\left(0,1,2,3\right.$ arba 4 balai); $U K_{\max }$ - didžiausias galimas ivvertinimas balais (4 balai); $n_{K}$ - respondentų skaičius.

Kriterijų, susietu su kelionès traukiniu proceso organizavimu ir technologija, daugiakriterio rodiklio $K_{B}$ skaičiavimo formulè užrašoma taip:

$$
\begin{aligned}
& K_{B}=\bar{Z}_{B}^{*} \cdot\left(\bar{Q}_{B 1} \cdot\left(1-\frac{\frac{\gamma \cdot\left(\left(t_{i \check{s}, l}+t_{i \check{s}, A}\right)^{2}-t_{i \check{s} v, l}^{2}+\left(t_{a t v, l}+t_{a t v, C}\right)^{2}-t_{a t \mathrm{v}, l}^{2}\right)+(1-\gamma) \times}{\times \sum_{e=1}^{b}\left(\left(t_{a \mathrm{tv}, l}+t_{a t v, B}\right)^{2}-t_{a t v, l}^{2}+\left(t_{i \check{s}, l}+t_{i \check{s ̌ v}, B}\right)^{2}-t_{i \check{s}, l}^{2}\right)_{e}}}{\beta \cdot(2+b) \cdot t_{a t v, l}^{2}}\right)+\right. \\
& \bar{Q}_{B 2} \cdot \frac{\sum_{c=1}^{V}\left(\frac{M D_{f}}{M D_{\max }}\right)_{c}}{V}+\bar{Q}_{B 3} \cdot \frac{\sum_{c=1}^{V}\left(\frac{P_{f}}{P_{\max }}\right)_{c}}{V}+\bar{Q}_{B 4} \cdot \frac{M U_{f}}{M U_{\max }}+\bar{Q}_{B 5} \cdot \frac{S P_{f}}{S P_{\max }}+ \\
& \bar{Q}_{B 6} \cdot \frac{I P_{f}}{I P_{\max }}+\bar{Q}_{B 7} \cdot \frac{B P_{f}}{B P_{\max }}+\bar{Q}_{B 8} \cdot \frac{V R R_{f}}{V R R_{\max }}+\bar{Q}_{B 9} \cdot \frac{T I_{f}}{T I_{\max }}+\bar{Q}_{B 10} \cdot \frac{M K_{f}}{M K_{\max }}+ \\
& \bar{Q}_{B 11} \cdot \frac{P S_{f}}{P S_{\max }}+\bar{Q}_{B 12} \cdot \frac{\sum_{k=1}^{n_{K}}\left(\frac{T M K_{f}}{T M K_{\max }}\right)_{k}}{n_{K}}+\bar{Q}_{B 13} \cdot \frac{B A_{f}}{B A_{\max }}+\bar{Q}_{B 14} \cdot \frac{M I D_{f}}{M I D_{\max }}+ \\
& \bar{Q}_{B 15} \cdot \frac{I V_{f}}{I V_{\max }}+\bar{Q}_{B 16} \cdot \frac{\sum_{k=1}^{n_{K}}\left(\frac{A P I_{f}}{A P I_{\max }}\right)_{k}}{n_{K}}+\bar{Q}_{B 17} \cdot \frac{\sum_{k=1}^{n_{K}}\left(\frac{A P B_{f}}{A P B_{\max }}\right)_{k}}{n_{K}}+ \\
& \left.\bar{Q}_{B 18} \cdot \frac{\sum_{P=1}^{n_{P}}\left(\frac{U K_{f}}{U K_{\max }}\right)_{p}}{n_{P}}+\bar{Q}_{B 19} \cdot \frac{\sum_{k=1}^{n_{K}}\left(\frac{M P K_{f}}{M P K_{\max }}\right)_{k}}{n_{K}}\right) .
\end{aligned}
$$


Naudojant eksperimentinių tyrimų duomenis ir kiekvieno kriterijaus kritines, leidžiamąsias ar geriausias vertes, iš šio modelio galima gauti B kriterijų grupès itaką TKVGK, išreikštą vienu parametru.

\subsubsection{Kriterijų, susietų su kelionès kaina, vertinimo modelis}

Suformuluoti ir pagrissti 6 kriterijai, susieti su kelionès traukiniu kaina (2.4 pav.), kurių KKVR $K_{C}$ dèmuo su iš ekspertinių tyrimų apskaičiuojamu vidutiniu svorio koeficientu $\bar{Z}_{C}^{*}$ ir kiekvieno kriterijaus svorio vidurkiu $\bar{Q}_{j}$ apskaičiuojamas pagal formulę:

$$
K_{C}=\bar{Z}_{C}^{*} \cdot\left(\bar{Q}_{C 1} \cdot x_{C 1}+\bar{Q}_{C 2} \cdot x_{C 2}+\ldots+\bar{Q}_{C 6} \cdot x_{C 6}\right),
$$

čia: $K_{C}$-tarptautinio traukinio KKVR ( $K_{C}$ kinta nuo 0 iki 1); $\bar{Z}_{C}^{*}$ - trijų kategorijų (K, P, A) respondentų ir ekspertų nuomonių apie $\mathrm{C}$ kriterijų grupès svarbą vidutinis svorio koeficientas; $\bar{Q}_{C 1}, \ldots, \bar{Q}_{C m}-\mathrm{C}$ kriterijų grupès j-ojo $(j=1,2, \ldots, m)$ kriterijaus svorio vidurkis, nustatytas ekspertų metodu; $x_{C 1}, \ldots, x_{C m}$ - C kriteriju grupés $j$-ojo $(j=1,2, \ldots, m)$ kriterijaus kintamasis dydis, nustatyti iš tyrimų ir norminių (reikiamų, siektinų) rodiklių lyginimo, iš kurio vertès apskaičiuojamas kriterijaus faktiškas lygmuo, kintantis nuo 0 iki 1 . Keleivių vežimo tarptautiniu traukiniu KKVR, ivertinančiam kelionès kainos itaka, apskaičiuoti, turime apskaičiuoti kiekvieno kriterijaus kintamuosius dydžius $x_{C 1}, \ldots, x_{C 6}$.

1. Bilieto kaina. Kai yra žinoma tam tikros kategorijos vagono didžiausia $B K_{\max }$ ir mažiausia $B K_{\min }$ bilieto kaina, tai KKVR $K$ dėmens, priklausančio nuo kelionès traukiniu kainos $K_{C}$, sandaugos $\bar{Q}_{C 1} \cdot x_{C 1}$, kintamojo dydžio $x_{C 1}$, rodančio bilieto kainos itaką, verte skaičiuojama pagal formulę:

$$
x_{C 1}=\frac{\sum_{y=1}^{3} V_{y} \cdot\left(1-\frac{B K_{f}-B K_{\min }}{B K_{\max }-B K_{\min }}\right)_{y}}{V},
$$

čia: $x_{C 1}-\mathrm{C}$ grupès 1-ojo kriterijaus kintamasis dydis; $V_{y}-y$-osios kategorijos sąstato vagonų skaičius, $\left(y=1,2, \ldots, V_{y}\right) B K_{f}, B K_{\min }, B K_{\max }-y$-osios kategorijos vagono faktine, mažiausia ir didžiausia bilieto kaina; $V$ - sąstato vagonų skaičius.

2. Restorano vagone parduodamų patiekalų kaina ir kokybè. Restorano vagone parduodamus patiekalus būtų galima vertinti pagal šiuos kriterijus:

- kaina;

- kokybe;

- asortimento gausa; 
- meniu keitimo periodiškumas.

Manoma, kad netikslinga diferencijuoti (imti skirtinga) kiekvieno iš šių kriterijų svori, todèl jis imamas lygus 0,25 . Tiksliau šių kriterijų itaką galima nustatyti ekspertu metodais.

Kainos itaką galima išreikšti formule:

$$
P K=\frac{P K_{\min }}{P K_{v i d}}=\frac{P K_{\min }}{\sum_{d=1}^{n_{D}}\left(\frac{P K_{d} \cdot J_{d}}{J}\right)},
$$

čia: $P K_{\min }-$ mažiausia restorano vagono patiekalo kaina, $\mathrm{Lt} ; P K_{\text {vid }}-$ vidutinè patiekalo kaina, Lt; $n_{D}$ - restorano vagone esančiu patiekalų skaičius, $(d=1,2$, $\left.\ldots, n_{D}\right) ; P K_{d}-d$-ojo patiekalo kaina, Lt; $J_{d}-d$-ojo patiekalo dažnis (parduotos porcijos); $J$ - visų restorano vagone parduotu patiekalų dažnis (parduotos porcijos), $\left(J=J_{1}+J_{2}+\ldots+J_{u}\right)$.

Maisto (patiekalu) kokybę galima (ivertinti balais) išreikšti formule:

$$
R M K=\frac{\sum_{i=1}^{n} B_{M K} \cdot n}{4 \cdot \sum n}=\frac{\left(B_{M K_{0}} \cdot n_{1}\right)+\left(B_{M K_{1}} \cdot n_{2}\right)+\ldots+\left(B_{M K_{n}} \cdot n_{i}\right)}{4 \cdot\left(n_{1}+n_{2}+\ldots+n_{i}\right)},
$$

čia: $R M K$ - maisto patiekalų kokybė; $B_{M K_{0}}, B_{M K_{1}}, \ldots, B_{M K_{n}}$ - maisto (patiekalo) ivertinimo balas ( $B_{M K_{0}}=0$ (labai blogai), $B_{M K_{1}}=1$ (blogai), $B_{M K_{2}}=2$ (patenkinamai), $B_{M K_{3}}=3$ (labai gerai), $B_{M K_{4}}=4$ (puiku); $n_{1}, n_{2}, \ldots, n_{i}$ - respondentu, ivertinusių maisto kokybę atitinkamu balu, skaičius $(i=1,2, \ldots, n)$.

Asortimento gausa apibūdinama tiriamojo laikotarpio patiekalų faktiško skaičiaus $A G_{f}$ ir daugiausia turètų patiekalų skaičiaus $A G_{\max }$ santykiu:

$$
A G=\frac{A G_{f}}{A G_{\max }},
$$

čia: $A G_{f}$ - faktiškas tiriamojo reiso restorano vagone esančių patiekalų skaičius; $A G_{\text {max }}$ - maksimalus kada nors buvęs restorano vagone patiekalų skaičius.

Patiekalų keitimo periodiškumui vertinti skiriami šie balai: 0 - patiekalai nekeičiami, 1 - patiekalai keičiami kas mènesị ir daugiau, 2 - patiekalai keičiami kas dvi savaites, 3 - patiekalai keičiami kas savaitę, 4 - patiekalai keičiami kiekvieną reisą. Patiekalų keitimo periodiškumas išreiškiamas faktiško patiekalų keitimo periodo vertinimo balo $P K P_{f}$ ir dažniausio patiekalų keitimo periodo vertinimo balo $P K P_{\max }$ santykiu: 


$$
P K P=\frac{P K P_{f}}{P K P_{\max }},
$$

čia: $P K P_{f}$ - faktiškas patiekalų keitimo periodo vertinimo balas; $P K P_{\max }-$ didžiausias patiekalų keitimo periodo vertinimo balas.

$\mathrm{KKVR} K_{C}$, ivvertinančio patiekalų kaina, kokybę, asortimento gausa, meniu keitimo periodiškumą, dèmuo skaičiuojamas pagal formulę:

$$
x_{C 2}=0,25 \cdot(P K+R M K+A G+P K P),
$$

čia: $x_{C 2}-\mathrm{C}$ grupès 2-ojo kriterijaus kintamasis dydis; $P K$ - restorano vagone parduodamų patiekalų kainos dèmuo; $R M K$ - maisto kokybès dèmuo; $A G$ - patiekalų gausos (pasirinkimo) demuo; $P K P$ - patiekalų keitimo periodiškumo dèmuo.

3. Laikraščių ir žurnalų kaina. Laikraščių ir žurnalų traukinyje kainai vertinti skiriami šie balai: 0 - laikraščiu ir žurnalų traukinyje kaina yra didesnè už parduodamų spaudos kioskuose, 1 - laikraščių ir žurnalų traukinyje kaina yra tokia pati, kaip parduodamų spaudos kioskuose, 2 - laikraščių ir žurnalų traukinyje kaina yra mažesnè už parduodamų spaudos kioskuose. KKVR $K_{C}$, ỉvertinančio laikraščių ir žurnalų traukinyje kainą, dèmuo skaičiuojamas pagal šią formulę:

$$
x_{C 3}=\frac{L \check{Z}_{f}}{L \check{Z}_{\max }},
$$

čia: $x_{C 3}-\mathrm{C}$ grupès 3-ojo kriterijaus kintamasis dydis; $L \check{Z}_{f}$ - laikraščių ir žurnalų traukinyje kainos vertinimas balais $\left(0,1\right.$ arba 2 balai); $L \check{Z}_{\max }$ - didžiausias galimas laikraščių ir žurnalų traukinyje kainos ịvertinimas balais (2 balai).

4. Užsienio medicininių išlaidų draudimo kaina. Šis draudimas reikalingas tada, kai dèl ūmaus sveikatos sutrikimo, ivvykusio kelionès metu, būtinoji medicinos pagalba suteikiama ambulatorineje ar stacionarioje gydymo istaigoje užsienyje. Draudimo agentūų yra keletas. Skirtingos medicininių išlaidų draudimo sumos, tarifai ir laikotarpiai. KKVR $K_{C}$, ivertinančio užsienio medicininių išlaidų draudimo kainą, dèmuo skaičiuojamas pagal šią formulę:

$$
x_{C 4}=1-\frac{M I D K_{f}-M I D K_{\min }}{M I D K_{\max }-M I D K_{\min }},
$$

čia: $x_{C 4}-\mathrm{C}$ grupès 3-ojo kriterijaus kintamasis dydis; $M I D K_{f}, M I D K_{\min }$, $M I D K_{\max }$ - faktinè, mažiausia ir didžiausia užsienio medicininių išlaidų draudimo kaina.

5. Vizų kaina. Kai yra žinoma kiekvienos šalies i / per kurią važiuoja traukinys didžiausia $V K_{\max }$ ir mažiausia $V K_{\min }$ vizos kaina, tai KKVR $K_{C}$, ivertinančio vizos kainą, dèmuo skaičiuojamas pagal šią formulę: 


$$
x_{C 5}=\frac{\sum_{w=1}^{n_{W}}\left(1-\frac{V K_{f}-V K_{\min }}{V K_{\max }-V K_{\min }}\right)_{w}}{n_{W}},
$$

čia: $x_{C 5}-\mathrm{C}$ grupès 3-ojo kriterijaus kintamasis dydis; $n_{W}$ - kelionei reikalingu vizų skaičius, $\left(w=1,2, \ldots, n_{W}\right) ; V K_{f}, V K_{\min }, V K_{\max }$ - faktinè, mažiausia ir didžiausia $w$-osios vizos kaina.

6. Keleivinio vagono su dvivietemis kupè maisto davinio (iskaičiuoto į bilieto kaina) pateikimas. Maisto davinio keleiviams pateikimui už i bilietą iskaičiuotą kainą vertinti skiriami šie balai: 0 - i vagono bilieto kainą neįskaičiuotas maisto davinys, todèl keleiviams nepateikiamas, 1 - $\mathfrak{i}$ vagono bilieto kainą ịskaičiuota vakarienè arba pusryčiai, 2 - i vagono bilieto kainą įskaičiuota vakariené ir pusryčiai. KKVR $K_{C}$, ivertinančio maisto davinio keleiviams pateikimą už i bilietą îskaičiuotą kainą miegamajame su 2-jų vietų kupe vagone, dèmuo skaičiuojamas pagal šią formulę:

$$
x_{C 6}=\frac{M P_{f}}{M P_{\max }},
$$

čia: $x_{C 6}-\mathrm{C}$ grupès 6-ojo kriterijaus kintamasis dydis; $M P_{f}-$ maisto davinio pateikimo arba nepateikimo už į bilietą îskaičiuotą (neįskaičiuota) kainą miegamajame su 2-jų vietų kupe vagone faktiškas ivvertinimas balais $(0,1$ arba 2 balai); $M P_{\max }$ - didžiausias galimas maisto davinio pateikimo už i bilietą iskaičiuotą kainą įvertinimo balas (2 balai).

Kriterijų, susietų su kelionès kaina, daugiakriterio rodiklio $K_{C}$ skaičiavimo formulè užrašoma taip:

$$
\begin{aligned}
& K_{C}=\bar{Z}_{C}^{*} \cdot\left(\bar{Q}_{C 1} \cdot \frac{\sum_{y=1}^{3} V_{y} \cdot\left(1-\frac{B K_{f}-B K_{\min }}{B K_{\max }-B K_{\min }}\right)_{y}}{V}+\bar{Q}_{C 2} \cdot(0,25 \cdot(P K+R M K+A G+\right. \\
& P K P))+\bar{Q}_{C 3} \cdot \frac{L \check{Z}_{f}}{L \check{Z}_{\max }}+\bar{Q}_{C 4} \cdot\left(1-\frac{M I D K_{f}-M I D K_{\min }}{M I D K_{\max }-M I D K_{\min }}\right)+ \\
& \left.\bar{Q}_{C 5} \cdot \frac{\sum_{w=1}^{n_{W}}\left(1-\frac{V K_{f}-V K_{\min }}{V K_{\max }-V K_{\min }}\right)_{w}}{n_{W}}+\bar{Q}_{C 6} \cdot \frac{M P_{f}}{M P_{\max }}\right) .
\end{aligned}
$$


Naudojant eksperimentinių tyrimų duomenis ir kiekvieno kriterijaus kritines, leidžiamąsias ar geriausias vertes, iš šio modelio galima gauti C kriterijų grupès itaką TKVGK, išreikštą vienu parametru.

\subsubsection{Kriteriju, susietų su kelionès traukiniu saugumu, vertinimo modelis}

Suformuluoti ir pagristi 8 kriterijai, susieti su kelionès traukiniu saugumu (2.4 pav.), kurių KKVR $K_{D}$ demuo su iš ekspertinių tyrimų apskaičiuojamu vidutiniu svorio koeficientu $\bar{Z}_{D}^{*}$ ir kiekvieno kriterijaus svorio vidurkiu $\bar{Q}_{j}$ apskaičiuojamas pagal formulę:

$$
K_{D}=\bar{Z}_{D}^{*} \cdot\left(\bar{Q}_{D 1} \cdot x_{D 1}+\bar{Q}_{D 2} \cdot x_{D 2}+\ldots+\bar{Q}_{D 8} \cdot x_{D 8}\right),
$$

čia: $K_{D}$ - tarptautinio traukinio $\operatorname{KKVR}\left(K_{D}\right.$ kinta nuo 0 iki 1$)$; $\bar{Z}_{D}^{*}$-trijų kategorijų (K, P, A) respondentų ir ekspertų nuomonių apie D kriterijų grupès svarbą vidutinis svorio koeficientas; $\bar{Q}_{D 1}, \ldots, \bar{Q}_{D m}-\mathrm{D}$ kriteriju grupés $j$-ojo $(j=1,2, \ldots$, $m)$ kriterijaus svorio vidurkis, nustatytas ekspertu metodu; $x_{D 1}, \ldots, x_{D m}-\mathrm{D}$ kriterijų grupès $j$-ojo $(j=1,2, \ldots, m)$ kriterijaus kintamasis dydis, nustatytas iš tyrimų ir norminių (reikiamų, siektinu) rodiklių lyginimo, iš kurių verčių apskaičiuojamas kriterijaus faktiškas lygmuo, kintantis nuo 0 iki 1 . Keleivių vežimo tarptautiniu traukiniu KKVR, ivvertinančiam kelionès kainos įtaką, apskaičiuoti, būtina apskaičiuoti kiekvieno kriterijaus kintamuosius dydžius $x_{D 1}, \ldots, x_{D 8}$.

1. Gaisro gesinimo priemonių buvimas ir būklè. Keleiviniuose, bagažo, pašto, pašto ir bagažo vagonuose su vaizdo technikos salonais, vagonuose su dyzeline elektros stotimi gaisro gesinimo priemonès naudojamos laikantis standartų ir techninių sąlygų. Be gesintuvų kiekvieno vagono elektros irenginių valdymo pulte pastatomas automatinis miltelinis (OSP-1) arba aerozolinis gaisro gesinimo įrenginys (GGI), turintis panašias technines charakteristikas. Kiekvienas keleivinio traukinio sąstatas aprūpinamas pramonine individualia izoliuojančia apsauga (IIA), ne mažiau kaip 3 vienetai vienam sąstatui. Šiuo metu tokia pramoniné IIA yra kiekviename sąstato vagone (1 vienetas vienam vagonui). Nauji keleiviniai vagonai, taip pat modernizuoti vagonai turi būti su automatiniu priešgaisrinès signalizacijos irenginiu (UPS), galinčiu nustatyti gaisro kilimą kontroliuojamose patalpose užsidegimo stadijoje ir apie tai pranešti (Tarptautinio susisiekimo tarp NVS šaliu, Estijos, Latvijos ir Lietuvos respubliku keleiviniu vagonu priešgaisrinès saugos užtikrinimo instrukcija 2003). Keleiviniuose vagonuose juos gaminant arba atliekant kapitalini atkuriamaji remontą (KAR), turi būti įrengiamas GGİ, leidžiantis panaudoti vandens atsargas iš vandens tiekimo sistemos (Tarptautinio susisiekimo tarp NVS šaliu, Estijos, Latvijos ir Lietuvos respubliku keleiviniai vagonai priešgaisrinès saugos reikalavimai 2003). 
Gesintuvų buvimui ir būklei kiekviename traukinio vagone vertinti skiriami šie balai: 0 - gesintuvai yra, bet jų kiekis neatitinka tarptautinio susisiekimo keleivinių vagonų aprūpinimo gesintuvais normų, jie (bent vienas iš jų) neužplombuoti arba plomba pažeista, 1 - gesintuvų skaičius atitinka tarptautinio susisiekimo keleivinių vagonų aprūpinimo gesintuvais normas, tačiau jie (bent vienas iš jų) neužplombuoti arba plomba pažeista, 2 - gesintuvų skaičius atitinka tarptautinio susisiekimo keleivinių vagonų aprūpinimo gesintuvais normas, jie užplombuoti.

OSP-1, skirto gesinti gaisrą elektros irenginių valdymo pulte, buvimui ir būklei kiekviename traukinio vagone vertinti skiriami šie balai: 0 - OSP-1 vagone nèra, 1 - OSP-1 vagone yra, tačiau techniškai netvarkingas: pasibaigęs jo galiojimo laikas arba yra mechaninių indo pažeidimų (suskilęs korpusas), jo pastatymas neatitinka konstrukcinès dokumentacijos reikalavimų, 2 - OSP-1 yra, jis techniškai tvarkingas: patikros atliktos laiku, nèra mechaninių indo pažeidimu, jo pastatymas atitinka konstrukcinès dokumentacijos reikalavimus.

Kiekvieno keleivinio vagono aprūpinimui pramonine IIA vertinti skiriami šie balai: 0 - IIA vagone nèra, 1 - IIA vagone yra, tačiau netvarkinga, 2 - IIA vagone yra ir ji tvarkinga.

UPS buvimui ir būklei vertinti kiekviename traukinio vagone skiriami šie balai: 0 - UPS nenumatytas vagono konstrukcijoje, 1 - UPS vagone yra, tačiau neveikia dèl gedimo, 2 - vagone yra veikiantis UPS, galintis siųsti akustinius ir optinius signalus apie užsidegima, nurodant gaisro vietą (patalpa) vagono viduje.

Automatinio GGI, leidžiančio panaudoti vandens atsargas iš vandens tiekimo sistemos, buvimui vagone ir būklei vertinti skiriami šie balai: 0 - automatinio GGI, leidžiančio panaudoti vandens atsargas iš vandens tiekimo sistemos, vagone nèra, 1 - automatinis GGİ, leidžiantis panaudoti vandens atsargas iš vandens tiekimo sistemos, vagone yra, tačiau netvarkingas, 2 - automatinis GGI vagone yra ir jis tvarkingas. KKVR $K$ dèmens, priklausančio nuo kelionès traukiniu saugumo $K_{D}$, sandaugos $\bar{Q}_{D 1} \cdot x_{D 1}$, kintamojo dydžio $x_{D 1}$, rodančio gaisro gesinimo (priešgaisrinès saugos) priemonių buvimo vagone ir jų būklès itaka, vertė skaičiuojama pagal formulę:

$$
\begin{aligned}
x_{D 1}= & \frac{\sum_{c=1}^{V} \sum_{o=1}^{F}\left(\frac{G G P_{f}}{G G P_{\max }}\right)_{c}}{V \cdot F}= \\
& \frac{\sum_{c=1}^{V} \sum_{o=1}^{F}\left(\frac{F E_{f}}{F E_{\max }}+\frac{O S P_{f}}{O S P_{\max }}+\frac{I I A_{f}}{I I A_{\max }}+\frac{U P S_{f}}{U P S_{\max }}+\frac{G G I_{f}}{G G I_{\max }}\right)_{c}}{V \cdot F},
\end{aligned}
$$

čia: $x_{D 1}$ - D grupès 1-ojo kriterijaus kintamasis dydis; $G G P_{f}, G G P_{\max }-$ gaisro gesinimo priemonių rūšių vagone faktiškas ir maksimalus ịvertinimas balais, $F E_{f}-$ 
faktiškas gesintuvų buvimo ir būklès $c$-ajame vagone ịvertinimas balais $(0,1$ arba 2 balai); $F E_{\max }$ - didžiausias galimas gesintuvų buvimo ir būklès $c$-ajame vagone iqvertinimas balais (2 balai); $O S P_{f}-\mathrm{OSP}-1$ buvimo ir būklès $c$-ajame vagone ịvertinimas balais ( 0,1 arba 2 balai); $O S P_{\max }$ - didžiausias galimas OSP-1 buvimo ir būklès $c$-ajame vagone ịvertinimas balais (2 balai); $I I A_{f}-c$-ojo vagono aprūpinimo pramonine IIA ir jos būklès vertinimas balais $(0,1$ arba 2 balai); $I I A_{\max }$ - didžiausias galimas vagono aprūpinimo pramonine IIA ir jos vertinimas balais ( 2 balai); $U P S_{f}$ - UPS buvimo ir būklès $c$-ajame vagone ịvertinimas balais ( 0,1 arba 2 balai); $U P S_{\max }$ - didžiausias galimas UPS buvimo ir būklès vagone ivertinimas balais (2 balai); $G G I_{f}-c$-ojo vagono automatinio GGI buvimo ir būklès vertinimas balais ( 0,1 arba 2 balai); $G G I_{\max }$ - didžiausias galimas vagono automatinio GGI buvimo ir būklès vertinimas balais ( 2 balai); $F$ - gaisro gesinimo priemonių rūšių vagone skaičius, $(o=1,2, \ldots, F) ; V$ - sąstato vagonų skaičius, $(c=1,2, \ldots, V)$.

2. Pirmosios medicinos pagalbos priemonių buvimas. Skiriami šie balai: $0-$ pirmosios medicinos pagalbos priemonių traukinyje nèra, 1 - vaistinèlè yra, tačiau joje esančių tvarsčių ir medikamentų nepakaktų ekstremaliais atvejais (pvz., teroristinio akto, katastrofos atveju), 2 - vaistinèlè yra ir joje esančių tvarsčių ir medikamentų pakaktų ekstremaliais atvejais. KKVR $K_{D}$, ivvertinančio pirmosios medicinos pagalbos priemonių buvimo ịtaka, dèmuo skaičiuojamas pagal formulę šią formulę:

$$
x_{D 2}=\frac{P M P_{f}}{P M P_{\max }},
$$

čia: $x_{D 2}$ - D grupès 2-ojo kriterijaus kintamasis dydis; $P M P_{f}$ - pirmosios medicinos pagalbos priemonių buvimo faktiškas vertinimas balais $(0,1$ arba 2 balai); $P M P_{\max }$ - didžiausias galimas pirmosios medicinos pagalbos priemonių buvimo vertinimas balais ( 2 balai).

3. Greitosios medicinos pagalbos iškvietimo galimybè. I traukini greitoji medicinos pagalba yra kviečiama tada, kai pirmosios medicinos pagalbos priemonių, esančiu traukinyje, nepakanka arba keleivis reikalauja medikų pagalbos. Ją iškviesti gali traukinio viršininkas radijo ryšiu per traukinio mašinistą artimiausioje stotyje. Radijo stotimi traukinyje turi teisę naudotis traukinio viršininkas arba elektrikas-mechanikas, o ju poilsio metu - traukinio štabo vagono budintis palydovas (Radijo ryšio tarp traukinio viršininko... 1999). Vertinant greitosios medicinos pagalbos iškvietimo i traukini galimybę skiriami šie balai: 0 - iškviesti i traukini greitają medicinos pagalbą galimybès nèra, 1 - iškviesti i traukini greitają medicinos pagalba galima radijo ryšiu, per traukinio mašinista, 2 - iškviesti i traukini greitają medicinos pagalbą galima tiesiogiai per artimiausios stoties budetoja (GSM-R radijo ryšio sistema). KKVR $K_{D}$, ivertinančio greitosios medicinos pagalbos iškvietimo į traukini galimybès įtaką, dėmuo skaičiuojamas pagal formulę: 


$$
x_{D 3}=\frac{G M P_{f}}{G M P_{\max }},
$$

čia: $x_{D 3}$ - D grupès 3-ojo kriterijaus kintamasis dydis; $G M P_{f}$ - greitosios medicinos pagalbos iškvietimo i traukini galimybès vertinimas balais $(0,1$ arba 2 balai); $G M P_{\max }$ - didžiausias galimas greitosios medicinos pagalbos iškvietimo i traukini galimybès vertinimas balais ( 2 balai).

4. Ašidèžiu perkaičio signalizacijos veikimas. Ašidèžiu ikaitimo kontrolès signalizacijos paskirtis - traukinio eismo saugumo efektyvumo didinimas. Ji nuolat kontroliuoja ašidèžiu ikkaitimo temperatūrą ir padeda išvengti avarijų, kai ikaista ir lūžta ritininiai guoliai. Guolio kaitimo atveju vagono valdymo pulte užsidega ašidèžių ikaitimo kontrolès signalizacijos lemputè ir skamba garso signalas. Ašiděžių ikaitimo kontrolès sistema yra tikrinama valdymo pulto jungikliu arba mygtuku. Ją išjungti griežtai draudžiama. Keleivinių vagonų ašidėžių ir ašies kakliuku (AKAK) ikkaičio ribinès reikšmès, ikaičio pavojingumui ịvertinti apžiūros metu matuojant bekontakčiais nuotolinio valdymo termometrais, užfiksavus ịkaiti važiuojančio traukinio techninès būklès automatinès kontrolès priemonèms (RAKP), kaip pavojingą bei kelianti grèsmę eismo saugumui, pateiktos 2.4 lenteleje.

2.4 lentelè. Keleivinių vagonų AKAK įkaičio, užfiksuoto važiuojančio traukinio techninès būklès automatinès kontrolès priemonių, ribinės reikšmès

Table 2.4. The limiting heating values for the axle box and the axle journal of passenger cars (AKAK), recorded by automatic control devices of the train's condition

\begin{tabular}{|c|c|}
\hline Aplinkos oro temperatūra & $\begin{array}{c}\text { (AKAK) ikaičio temperatūros } \\
\text { ribinès reikšmès }\left({ }^{\circ} \mathrm{C}\right)\end{array}$ \\
\hline nuo -20 iki -30 ir žemesnè & 20 \\
\hline nuo $-10 \mathrm{iki}-20$ ir žemesne & 30 \\
\hline nuo $-1 \mathrm{iki}-10$ ir žemesnè & 40 \\
\hline nuo $0 \mathrm{iki}+10$ ir žemesne & 50 \\
\hline nuo $+11 \mathrm{iki}+20$ ir žemesne & 60 \\
\hline nuo +21 ir aukštesnè & 70 \\
\hline
\end{tabular}

Šaltinis: Norminis AB ,Lietuvos geležinkeliai“ dokumentas

Lentelèje (2.4) yra nekorektiškų verčių: neaišku, kaip vertinti temperatūra, jeigu yra $10,5^{\circ} \mathrm{C}$ arba $20,5^{\circ} \mathrm{C}$. Temperatūra -30 yra žemesnè už -20 , todèl reikètų rašyti nuo -30 iki -20 .

Nors vienai traukinio vagono AKAK temperatūrai viršijus kritinę vertę, kyla pavojus ne tik to aširačio kakliukui lūžti ir vagonui nueiti nuo bẻgių, bet ir visam traukiniui patirti katastrofą. Vertinti traukinio kokybę pagal visų aširačių 
AKAK faktinès temperatūros atitiktị kritinei temperatūrai, skaičiuojant vidutines vertes, nèra logiška. Viso sąstato kokybę pagal temperatūrą reikètų vertinti pagal blogiausią AKAK vertę ir neskaičiuoti aritmetinių nei kitokių vidurkių (geometrinių, svertiniu).

KKVR $K_{D}$, ivvertinančio ašidèžių ikaitimo kontrolès signalizacijos veikimo itaką, dėmuo skaičiuojamas pagal formulę:

$$
x_{D 4}=\frac{T_{\text {rib }}-T_{f}}{T_{\text {rib }}-T_{\text {apl.oro }}}=\frac{\left(0,92 \cdot T_{\text {apl.oro }}+45\right)-T_{f}}{\left(0,92 \cdot T_{\text {apl.oro }}+45\right)-T_{\text {apl.oro }}},
$$

čia: $x_{D 4}-\mathrm{D}$ grupès 4-ojo kriterijaus kintamasis dydis; $T_{f}-\mathrm{AKAK}$ išmatuota temperatūra, ${ }^{\circ} \mathrm{C} ; T_{\text {apl.oro }}$ - aplinkos oro temperatūra matuojamoje vietoje (stotyje), ${ }^{\circ} \mathrm{C} ; T_{r i b}$ - ribinè (didžiausia leidžiama) AKAK temperatūra, priklausanti nuo aplinkos oro temperatūros, pateikta norminiame dokumente, ${ }^{\circ} \mathrm{C}$.

5. Avarinių išejjimų buvimas. Gaminamuose ir KAR metu vagonuose turi būti irengiami papildomi avariniai išèjimai. Avarinių išèjimu skaičius (ne mažesnis kaip du) ir jų vieta turi sudaryti sąlygas užbaigti evakuoti keleivius iki pavojingi gaisro veiksniai (PGV) pasieks ribines leidžiamas reikšmes (Tarptautinio susisiekimo tarp NVS šaliu... 2003). Avarinių išèjimų buvimui kiekviename traukinio vagone vertinti skiriami šie balai: 0 - avarinių išejimų vagone nèra, 1 avariniai išèjimai vagone yra (mažiau nei du), 2 - avariniai išějimai vagone yra (ne mažiau kaip du). KKVR $K_{D}$, ivvertinančio avarinių išejimų buvimo kiekviename traukinio vagone įtaka, dèmuo skaičiuojamas pagal formulę:

$$
x_{D 5}=\frac{\sum_{c=1}^{V}\left(\frac{A I_{f}}{A I_{\max }}\right)_{c}}{V}
$$

čia: $x_{D 5}-\mathrm{D}$ grupès 5-ojo kriterijaus kintamasis dydis; $A I_{f}$ - avarinių išejimų buvimo $c$-ajame vagone vertinimas balais ( 0,1 arba 2 balai); $A I_{\max }$ - didžiausias galimas avarinių išejimų buvimo vagone vertinimo balas (2 balai); $V$ - sąstato vagonų skaičius.

6. Turèklų, laiptelių, perèjimo aikštelių, durų ir spynų tvarkingumas. Kelionès metu sugedusius turèklus, laiptelius, duris ir kt. remontuoja traukinio elektrikas-mechanikas. Vagono turéklų, laiptelių, perejjimo aikštelių, durų ir spynų tvarkingumui vertinti skiriami šie balai: 0 - vagono turèklai, laipteliai, perejjimo aikštelès, durys ir spynos yra techniškai netvarkingi, 1 - vagono turèklai yra tvarkingi, o laipteliai, perejjimo aikštelès, durys ir spynos yra techniškai netvarkingi, 2 - vagono turèklai ir laipteliai yra tvarkingi, o perejjimo aikštelès, durys ir spynos yra techniškai netvarkingos, 3 - vagono turèklai, laipteliai ir perejjimo aikštelès yra tvarkingi, o durys ir spynos yra techniškai netvarkingos, 4 vagono turèklai, laipteliai, perejimo aikštelès, durys ir spynos yra techniškai 
tvarkingi. KKVR $K_{D}$, ivvertinančio vagono turèklų, laiptelių, perèjimo aikštelių, durų ir spynų tvarkingumo įtaką, dėmuo skaičiuojamas pagal šią formulę:

$$
x_{D 6}=\frac{\sum_{c=1}^{V}\left(\frac{V T T_{f}}{V T T_{\max }}\right)_{c}}{V},
$$

čia: $x_{D 6}$ - D grupès 6-ojo kriterijaus kintamasis dydis; $V T T_{f}$ - turèklų, laiptelių, perejimo aikšteliu, durų ir spynų tvarkingumo $c$-ajame traukinio vagone ivertinimas balais $\left(0,1,2,3\right.$ arba 4 balai); $V T T_{\max }$ - didžiausias galimas vagono turèklų, laipteliu, perejimo aikštelių, durų ir spynų tvarkingumo įvertinimas balais (4 balai); $V$ - sąstato vagonų skaičius.

7. Rankinio stabdžio būkle ir veikimas, stabdų būklè. Vagone yra dviejų rūšių traukinio stabdymo priemonès: rankinis stabdys ir 4 stabdai (skubaus stabdymo rankenèlès).

Rankinio stabdžio būklei ir veikimui vertinti kiekviename traukinio vagone skiriami šie balai: 0 - nèra rankinio stabdžio rankenos, jis neveikia, 1 - stabdžio rankena yra, bet jis neveikia arba rankenos nèra, bet stabdžio mechanizmas veikia, 2 - rankinio stabdžio rankena yra ir jis puikiai veikia.

Stabdų būklei vertinti kiekviename traukinio vagone skiriami šie balai: 0 - visi stabdai neužplombuoti, 1 - trys stabdai neužplombuoti, 2 - du stabdai neužplombuoti, 3 - vienas stabdas neužplombuotas, 4 - visi keturi stabdai užplombuoti.

KKVR $K_{D}$, ivertinančio rankinio stabdžio būklès ir veikimo, taip pat stabdų būklès kiekviename traukinio vagone įtaką, dèmuo skaičiuojamas pagal šią formulę:

$$
x_{D 7}=\frac{\sum_{c=1}^{V} \sum_{h=1}^{H}\left(\frac{T S P_{f}}{T S P_{\max }}\right)_{c}}{V \cdot H}=\frac{\sum_{c=1}^{V}\left(\frac{R S_{f}}{R S_{\max }}+\frac{S K_{f}}{S K_{\max }}\right)_{c}}{V \cdot H},
$$

čia: $x_{D 7}-\mathrm{D}$ grupès 7-ojo kriterijaus kintamasis dydis; $T S P_{f}, T S P_{\max }-$ traukinio stabdymo priemonių rūšių faktiškoji ir maksimali vertè; $R S_{f}$ - rankinio stabdžio būklès ir veikimo $c$-ajame vagone vertinimas balais $\left(0,1\right.$ arba 2 balai); $R S_{\max }-$ didžiausias galimas rankinio stabdžio būklès ir veikimo vertinimo balas ( 2 balai); $S K_{f}$ - stabdų būklès $c$-ajame vagone vertinimas balais $(0,1,2,3$ arba 4 balai); $S K_{f}$ - stabdų būklès $c$-ajame vagone didžiausias galimas vertinimas balais (4 balai); $V$-sąstato vagonų skaičius, $(c=1,2, \ldots, V) ; H$ - traukinio stabdymo priemonių vagone rūšių skaičius, $(h=1,2, \ldots, H)$.

8. Policijos pareigūnų iškvietimo galimybè. Vertinant policijos iškvietimo i traukini galimybę skiriami šie balai: 0 - iškviesti i traukini policijos pareigūnus 
galimybès nèra, 1 - iškviesti i traukinị policijos pareigūnus galima radijo ryšiu, per traukinio mašinista, 2 - iškviesti i traukini policijos pareigūnus galima tiesiogiai per artimiausios stoties budetoją (GSM-R radijo ryšio sistema). KKVR $K_{D}$, ivertinančio policijos pareigūnų iškvietimo į traukini galimybès įtaka, demuo skaičiuojamas pagal šią formulę:

$$
x_{D 8}=\frac{P P I_{f}}{P P I_{\max }},
$$

čia: $x_{D 8}-\mathrm{D}$ grupès 8-ojo kriterijaus kintamasis dydis; $P P I_{f}-$ policijos pareigūnų iškvietimo i traukini galimybès vertinimas balais $\left(0,1\right.$ arba 2 balai); $P P I_{\max }-$ didžiausias galimas policijos pareigūnų iškvietimo ị traukini galimybès vertinimas balais ( 2 balai).

Kriterijų, susietų su kelionès traukiniu saugumu, daugiakriterio rodiklio $K_{D}$ skaičiavimo formulè užrašoma taip:

$$
\begin{aligned}
K_{D}= & \bar{Z}_{D}^{*} \cdot\left(\bar{Q}_{D 1} \cdot \frac{\sum_{c=1}^{V} \sum_{o=1}^{F}\left(\frac{G G P_{f}}{G G P_{\max }}\right)_{c}}{V \cdot F}+\bar{Q}_{D 2} \cdot \frac{P M P_{f}}{P M P_{\max }}+\bar{Q}_{D 3} \cdot \frac{G M P_{f}}{G M P_{\max }}+\right. \\
& \bar{Q}_{D 4} \cdot\left(\frac{T_{r i b}-T_{f}}{T_{r i b}-T_{\text {apl.oro }}}\right)+\bar{Q}_{D 5} \cdot \frac{\sum_{c=1}^{V}\left(\frac{A I_{f}}{A I_{\max }}\right)_{c}}{V}+\bar{Q}_{D 6} \cdot \frac{\sum_{c=1}^{V}\left(\frac{V T T_{f}}{V T T_{\max }}\right)_{c}}{V}+ \\
& \left.\bar{Q}_{D 7} \cdot \frac{\sum_{c=1}^{V} \sum_{h=1}^{H}\left(\frac{T S P_{f}}{T S P_{\max }}\right)_{c}}{V \cdot H}+\bar{Q}_{D 8} \cdot \frac{P P I_{f}}{P P I_{\max }}\right) .
\end{aligned}
$$

Naudojant eksperimentinių tyrimų duomenis ir kiekvieno kriterijaus kritines, leidžiamąsias ar geriausias vertes, iš šio modelio galima gauti D kriterijų grupès itaką TKVGK, išreikštą vienu parametru.

Bendras tarptautinio susisiekimo traukinio KKVR $K$ skaičiavimo modelis su iš ekspertinių tyrimų apskaičiuojamais rodiklių ir ju grupių svorio koeficientais apskaičiuojamas pagal formulę:

$$
\begin{aligned}
K= & \sum_{g=1}^{M}\left[\bar{Z}_{g}^{*} \cdot\left(\sum_{j=1}^{m} \bar{Q}_{g j} \cdot x_{g j}\right)\right]=\bar{Z}_{A}^{*} \cdot\left(\bar{Q}_{A 1} \cdot x_{A 1}+\bar{Q}_{A 2} \cdot x_{A 2}+\ldots+\bar{Q}_{A 16} \cdot x_{A 16}\right)+ \\
& \bar{Z}_{B}^{*} \cdot\left(\bar{Q}_{B 1} \cdot x_{B 1}+\bar{Q}_{B 2} \cdot x_{B 2}+\ldots+\bar{Q}_{B 19} \cdot x_{B 19}\right)+
\end{aligned}
$$




$$
\begin{aligned}
& \bar{Z}_{C}^{*} \cdot\left(\bar{Q}_{C 1} \cdot x_{C 1}+\bar{Q}_{C 2} \cdot x_{C 2}+\ldots+\bar{Q}_{C 6} \cdot x_{C 6}\right)+ \\
& \bar{Z}_{D}^{*} \cdot\left(\bar{Q}_{D 1} \cdot x_{D 1}+\bar{Q}_{D 2} \cdot x_{D 2}+\ldots+\bar{Q}_{D 8} \cdot x_{D 8}\right) .
\end{aligned}
$$

čia: $K$ - tarptautinio traukinio $\operatorname{KKVR}(K$ kinta nuo 0 iki 1$) ; \bar{Z}_{A}^{*}, \bar{Z}_{B}^{*}$, $\bar{Z}_{C}^{*}, \bar{Z}_{D}^{*}$ - kriteriju grupių vidutinis svorio koeficientas; $\bar{Q}_{A 1}, \bar{Q}_{B 1}, \bar{Q}_{C 1}, \bar{Q}_{D 1}, \ldots$, $\bar{Q}_{A m}, \bar{Q}_{B m}, \bar{Q}_{C m}, \bar{Q}_{D m}-g$-osios grupès $j$-ojo $(j=1,2, \ldots, m)$ kriterijaus svorio vidurkis, nustatomas ekspertu metodu; $x_{A 1}, x_{B 1}, x_{C 1}, x_{D 1}, \ldots, x_{A m}, x_{B m}, x_{C m}, x_{D m}-g$ osios grupès $j$-ojo $(j=1,2, \ldots, m)$ kriterijaus kintamasis dydis, iš kurio vertés apskaičiuojamas kriterijaus faktiškas lygmuo, kintantis nuo 0 iki 1.

\subsection{Antrojo skyriaus išvados}

1. Kelionès traukiniu kokybę rodo visuma kriterijų, priklausančių nuo geležinkelio kelio ir riedmenų (traukinio elementu) parametrų keleivių vežimo organizavimo ir technologijos proceso rodiklių, taip pat nuo kelionès kainos ir kelionès traukiniu saugumo.

2. Kelionès traukiniu proceso kriterijai skirtingai veikia keleivio patoguma, sauguma, važiavimo trukmę, kainą ir pasitenkinimą kelione.

3. Kelionès atskirais tarptautiniais traukiniais kokybę patogu vertinti vienu parametru, t. y. KKVR įverčiu $K(K=0-1)$.

4. Pasiūlytas daugiakriteris adityvinis modelis KKVR skaičiuoti, kuriame vertinami atskirų kriterijų normalizuotieji svorių koeficientai. Sudarant atskirų grupių kriterijų vertinimo modelius paaiškejo, kad kiekvieno kriterijaus kintamiesiems dydžiams $x_{j}\left(x_{j}=0-1\right)$ nustatyti reikalinga savita metodika, kuri skiriasi savo sudètingumu. Visi sudaryti kriterijų vertinimo modeliai yra universalūs ir gali būti pritaikyti bet kuriam, tarptautinio traukinio KKVR įverčiui $K$ skaičiuoti.

5. Pasirinkto metodo taikymo atveju turi būti nustatyti kelionès traukiniu kokybès kriterijai, atskiru kriteriju grupių vidutiniai svorio koeficientai $\bar{Z}_{g}^{*}$, kriterijų svorio vidurkiai $\bar{Q}_{j}$ ir kintamieji dydžiai $x_{j}$. 



\section{Keleivių vežimo geležinkeliais kokybės kriterijų ir ju grupių svarbos tyrimas eksperimentiniais metodais}

TKVG (kelioné traukiniu) yra sudetingas procesas, kuriame dalyvauja suinteresuotos grupès: administracija, traukini aptarnaujantis personalas ir patys keleiviai. Organizuojant vežimo procesą ir priimant sprendimus, būtina atsižvelgti i šių suinteresuotu grupių paskirti, poreikius ir galimybes. Keleiviu vežimo (kelionės traukiniu) problemų sprendimas priklauso nuo šiame procese dalyvaujančių specialistų patirties, kvalifikacijos ir jų priimamų sprendimų. Norédamos pagerinti keleivių vežimo kokybę, suinteresuotos grupès turi derinti savo veiksmus, bendradarbiauti šios veiklos klausimais, keistis reikalinga informacija. TKVGK gerinimas yra sudètinga problema, reikalaujanti profesionalumo, pagristo žiniomis ir praktine patirtimi, intelekto ir nuolatinio idejų atnaujinimo.

2.4 paveiksle pateikta KTK rodančių veiksnių schema, kurios A, B, C, D kriteriju grupių numeriai atitinka respondentu (keleivių, važiavusių tarptautinio maršruto Vilnius-Maskva traukiniu) ir ekspertų (tarptautinių maršrutų traukinius aptarnaujančio personalo ir AB „Lietuvos geležinkeliai“ Keleivių vežimo direkcijos administracijos darbuotojų) apklausos keturių anketų struktūrą ir klausimų numerius (Маскелюнайте, Сивилявичюс 2008; Маскелюнайте, Сивилявичюс 2009c). Kiekvienos iš trijų kategorijų apklaustujų (respondentų ir ekspertų) 
atsakymų i kiekvienos anketos klausimus duomenų (kriterijų) svarbumui (svoriui) nustatyti pritaikytas T. Saaty porinio lyginimo AHP metodas (Maskeliūnaitè et al. 2009a; Sivilevičius, Maskeliūnaitè 2010; Maskeliūnaitè, Sivilevičius 2012). Iš visu gautu anketų panaudotos tik tos, kurias vertinant nebuvo prieštaravimu. Pateiktas skaičiavimo pavyzdys ir TKVGK tyrimo algoritmas (Maskeliunaite, Sivilevicius 2011), taip pat respondentu ir ekspertų nuomonių suderinamumo nustatant TKVGK kriteriju grupių A, B, C ir D svarbą skaičiavimo metodika. Susisteminti ir apdoroti anketiniai respondentų ir ekspertų (Maskeliūnaité, Sivilevičius 2009b) apklausos duomenys, atlikta jų nuomonių analizè. Skyriaus pabaigoje pateikiamos tyrimais pagristos išvados.

\subsection{Keleivių vežimo geležinkeliais kokybės kriterijų svarbos tyrimas AHP metodu}

Važiavimas traukiniais turi būti saugus ir patogus. Tik taip galima pritraukti daugiau keleivių ir užtikrinti geležinkeliams tvirtesnę padètį transporto rinkoje. Norint pritraukti kuo daugiau keleivių, būtina gerinti vežimo paslaugas: privaloma ne tik turèti kokybiškus riedmenis, bet ir nustatyti keleivių poreikius. Tam yra tikslinga atlikti išsamius KTK tyrimus.

\subsubsection{Anketų struktūra, respondentai ir ekspertai}

Buvo nustatyti ir susisteminti KTK rodantys kriterijai, parengtos šiam metodui taikyti tinkančios apklausos anketos (2.4 pav.), kurios buvo iteiktos keleiviams ir traukini aptarnaujančiam personalui bei $\mathrm{AB}$ „Lietuvos geležinkeliai“ Keleivių vežimo direkcijos administracijos darbuotojams. Anketavimas vyko traukinyje Vilnius-Maskva. Anketa buvo išversta $i$ anglų ir rusų kalbas. Keleiviams buvo išdalytos 32 tyrimo anketos. Tyrime dalyvavo 18 Lietuvos, 9 Rusijos, 1 JAV, 1 Ispanijos, 1 Italijos, 1 Vokietijos ir 1 Didžiosios Britanijos piliečiai. Tyrimui buvo panauda 10 keleivių anketu (3 Lietuvos, 4 Rusijos, 1 JAV, 1 Vokietijos ir 1 Italijos piliečiu), kadangi 22 anketu vertinimai buvo prieštaringi, jos buvo atmestos ir ju duomenys tyrime nepanaudoti. Traukini aptarnaujančiam personalui buvo iteikta 17 anketų. Tyrimui buvo panauda 11 traukini aptarnaujančio personalo anketų, nes dèl prieštaringų vertinimu 6 anketos buvo atmestos. AB „Lietuvos geležinkeliai“ Keleivių vežimo administracijos darbuotojams buvo iteiktos 4 anketos. Tyrimui buvo panaudotos 3 tyrimo anketos. 1-os anketos vertinimai buvo prieštaringi, todèl ji buvo atmesta.

Respondentams ir ekspertams įteiktų bei užpildytų, įvertintų ir atliekant tyrimą panaudotų anketų skaičius pateiktas 3.1 lentelejje. 
3.1 lentelè. Respondentams ir ekspertams įteiktų bei užpildytų, ivvertintų ir atliekant tyrimą panaudotų anketų skaičius

Table 3.1. The number of questionnaires, distributed among the respondents and experts

\begin{tabular}{|c|c|c|c|c|}
\hline \multirow{2}{*}{ Respondentų ar ekspertų kategorija } & \multicolumn{4}{|c|}{ Iteiktos (Panaudotos) } \\
\cline { 2 - 5 } & \multicolumn{4}{|c|}{ Kriterijų grupės } \\
\cline { 2 - 5 } & A & B & C & D \\
\hline K & $32(10)$ & $32(10)$ & $32(10)$ & $32(10)$ \\
\hline P & $17(11)$ & $17(11)$ & $17(11)$ & $17(11)$ \\
\hline A & $4(3)$ & $4(3)$ & $4(3)$ & $4(3)$ \\
\hline
\end{tabular}

*Respondentų ir ekspertų kategorijų žymenys: K - keleiviai, P - traukinį aptarnaujantis personalas, A - administracijos darbuotojai

Taikyti AHP metodą tyrimui traukinyje buvo sunku. Keleiviai buvo neiniciatyvūs respondenai. Keleivị reikèjo ịkalbèti užpildyti anketa, sudominti tyrimu, itikinti jo prasmingumu. Sutikusiam užpildyti anketą keleiviui, esant galimybei, buvo suteikiamos geresnès važiavimo sąlygos, pavyzdžiui, važiuoti vienam atskiroje kupé. Užpildyti anketas buvo prašoma dažnai traukiniu keliaujančių, jau pažistamų keleivių. Dèl traukinį aptarnaujančio personalo (traukinio viršininkų, vagonų palydovų) ir pačių keleivių pasyvumo, abejingumo tyrimui (mieliau skaitè knygą arba lankėsi restorano vagone), nepavyko apklausos atlikti kitų maršrutų traukiniuose, apklausti daugiau keleivių. Padidinti respondentų skaičių neretai trukdè ir tokios aplinkybès, kai jau sutikęs ir pradejjęs pildyti anketą keleivis buvo priverstas iš traukinio išlipti pasienio stotyje dèl netvarkingų asmens dokumentų.

\subsubsection{Vieno eksperto nuomonès apie kriteriju svarbą nustatymas}

Taikant sprendimų prièmimo sistemą svarbu nustatyti suformuotų rodiklių reikšmingumą. Kokybę galima apibūdinti tik tam tikra kriterijų sistema. Kriterijai, išsamiai apibūdinantys kokybę, nèra vienodai svarbūs. Be to, kiekvienas kriterijus gali apibūdinti skirtingą kokybès lygi. Norint nustatyti kompleksinę kokybę, reikia apskaičiuoti kriterijų reikšmes ir reikšmingumus (Zavadskas et al. 2001).

TKVGK rodiklių (kriteriju) svorių reikšmių nustatymo metodai priskiriami subjektyviems, jeigu kriterijai vertinami respondentų ar specialistų (ekspertu). Taikant subjektyvų vertinimą būtina aukšta specialistų (ekspertų) kvalifikacija, nes nuo jos priklauso nuomonių suderinamumas. Tam gerai tinka T. Saaty pasiūlytas rodiklių (kriterijų) porinio lyginimo metodas (Saaty 1980a; Саати 1993). Jis leidžia nustatyti vieno lygio hierarchijos rodiklių svorius (svarba) aukštesnio lygio atžvilgiu arba hierarchiškai nestruktūrizuotų rodiklių svorius. Ekspertai 
tarpusavyje lygina visus vertinamus rodiklius (kriterijus) $R_{i}$ ir $R_{j}(i=1,2, \ldots, n$; $j=1,2, \ldots, m)$, čia: $n$ - respondentų (ekspertu) skaičius; $m$ - lyginamų rodiklių (kriterijų) skaičius. AHP metodas yra ypatingas tuo, kad reikalauja aukšto loginio mąstymo. Vieno labai kompetentingo eksperto nuomonė yra svarbesnè už keliolikos nepatyrusių (nesugebančių logiškai mąstyti) specialistų nuomonę, todèl tyrèjai dažniausiai apklausia keletą patyrusių ekspertu, pvz., 5 ekspertus (Farhan, Fwa 2009). Metodas patogus, nes paprasčiau lyginti rodiklius po du, o ne juos visus iš karto. Nurodoma, kiek vienas rodiklis yra svarbesnis už kitą. Galima ekspertų rodikliams suteiktus kokybinius įverčius pertvarkyti į kiekybinius.

Vertinimo rodikliu lyginimo $\left(a_{j i}=1 / a_{i j}\right)$ matrica atrodo taip (Saaty 1980b; Sivilevičius 2011a; Turskis, Zavadskas 2010; Vilčeková et al. 2011):

$$
\begin{gathered}
\boldsymbol{A}=\left(a_{i j}\right)=\left[\begin{array}{cccc}
1 & \frac{w_{1}}{w_{2}} & \cdots & \frac{w_{1}}{w_{m}} \\
\frac{w_{2}}{w_{1}} & 1 & \cdots & \frac{w_{2}}{w_{m}} \\
\vdots & \vdots & \ddots & \vdots \\
\frac{w_{m}}{w_{1}} & \frac{w_{m}}{w_{2}} & \cdots & 1
\end{array}\right], \\
a_{i i}=1, a_{i j}=\frac{1}{a_{j i}}, a_{i j} \neq 0 .
\end{gathered}
$$

Tikrinį vektoriu galima apskaičiuoti keturiais būdais (Шикин, Чхартишвили 2000).

1. Kiekvienos eilutès elementai sudauginami ir gauti rezultatai surašomi eilute:

$$
\omega_{i}^{\prime \prime}=\prod_{j=1}^{m} a_{i j}
$$

2. Iš kiekvienos gautos eilutès elemento ištraukiama $m$-ojo laipsnio šaknis (lyginamų kriterijų skaičius $m=6$, todèl traukiama 6-ojo laipsnio šaknis), gaunamas normalizuotų reikšmių geometrinis vidurkis. Gauti rezultatai surašomi eilute:

$$
\omega_{i}^{\prime}=\sqrt[m]{\prod_{j=1}^{m} a_{i j}} .
$$

3. Sudedami šios eilutès elementai: 


$$
\sum_{i=1}^{m} \omega_{i}^{\prime}=\sum_{i=1}^{m} \sqrt[m]{\prod_{j=1}^{m} a_{i j}} .
$$

4. Kiekvienas šios eilutès elementas dalijamas iš gautos sumos, t. y. reikšmès normalizuojamos:

$$
\begin{gathered}
\omega_{i}=\frac{\sqrt[m]{\prod_{j=1}^{m} a_{i j}}}{\sum_{i=1}^{m} \sqrt[m]{\prod_{j=1}^{m} a_{i j}}} \\
\sum_{i=1}^{m} \omega_{i}=1
\end{gathered}
$$

Taigi, tikrinis vektorius $\omega$ yra surastas (4 žingsnis). Visų jo elementų suma yra lygi vienetui.

\subsubsection{Anketos duomenu tvarkymo skaitinis pavyzdys}

KTK vertinti buvo nustatyti 6 kriteriju, susietų su kelionès kaina (C grupès kriterijai) (2.4 pav.), svoriai. Keleiviams buvo itteikta rodiklių porinio lyginimo anketa. Užpildytas lyginimo matricos pavyzdys pateiktas 3.2 lentelèje.

3.2. lentelè. Ketvirto respondento (keleivio) kriterijų, susietų su kelionės kaina, porinio lyginimo pavyzdys

Table 3.2. An example of the 4th respondent's pairwise comparison of the criteria, describing ticket price

\begin{tabular}{|c|c|c|c|c|c|c|}
\hline Kriterijaus numeris & 1 & 2 & 3 & 4 & 5 & 6 \\
\hline 1 & 1 & 7 & 7 & 3 & 1 & 3 \\
\hline 2 & $1 / 7$ & 1 & 3 & 1 & $1 / 5$ & 1 \\
\hline 3 & $1 / 7$ & $1 / 3$ & 1 & $1 / 3$ & $1 / 9$ & $1 / 5$ \\
\hline 4 & $1 / 3$ & 1 & 3 & 1 & $1 / 5$ & $1 / 3$ \\
\hline 5 & 1 & 5 & 9 & 5 & 1 & 7 \\
\hline 6 & $1 / 3$ & 1 & 5 & 3 & $1 / 7$ & 1 \\
\hline
\end{tabular}

Reikia surasti tikrinị vektorių. Naudojamas ketvirtasis būdas, kurio skaičiavimo seka tokia: anketos kiekvienos eilutès elementai sudauginami ir gauti rezultatai surašomi eilute; iš kiekvieno gautos eilutès elemento ištraukiama $m$-ojo laipsnio šaknis; sudedami šios eilutès elementai; kiekvienas elementas dalijamas iš gautos sumos. Naudojant bent kurį iš šių keturių būdų idealios matricos atveju gaunamas vienas ir tas pats tikslus rezultatas (Шикин, Чхартишвили 2000). 
Iš 3.2 lentelès duomenų surandamas tikrinis vektorius taikant 4 skaičiavimo būdą. Tikrinio vektoriaus skaičiavimo eiga ir kiekvieno skaičiavimo žingsnio rezultatai pateikti 3.3 lentelèje.

Dabar reikia surasti didžiausią tikrinę šios matricos reikšmę $\lambda_{\max }$.

Matrica $\boldsymbol{A}$ dauginama iš tikrinio vektoriaus $\boldsymbol{\omega}$ (4 žingsnis):

$$
A \boldsymbol{\omega}=\left(\begin{array}{cccc}
\frac{\omega_{1}}{\omega_{1}} & \frac{\omega_{1}}{\omega_{2}} & \ldots & \frac{\omega_{1}}{\omega_{m}} \\
\frac{\omega_{2}}{\omega_{1}} & \frac{\omega_{2}}{\omega_{2}} & \ldots & \frac{\omega_{2}}{\omega_{m}} \\
\cdots \cdots \cdots \cdots \cdots \cdots \cdots \cdots . . . \\
\frac{\omega_{m}}{\omega_{1}} & \frac{\omega_{m}}{\omega_{2}} & \ldots & \frac{\omega_{m}}{\omega_{m}}
\end{array}\right)\left(\begin{array}{l}
\omega_{1} \\
\omega_{2} \\
\cdots \\
\omega_{m}
\end{array}\right)=\lambda \boldsymbol{\omega} .
$$

Sudauginami 3.2 lentelès pirmos eilutès elementai iš tikrinio vektoriaus $\boldsymbol{\omega}$ :

$$
\begin{gathered}
1 \cdot 0,3178+7 \cdot 0,0765+7 \cdot 0,0306+3 \cdot 0,0733+1 \cdot 0,3929+ \\
3 \cdot 0,1089=2,0071 .
\end{gathered}
$$

Padalijus surastos eilutès pirmą elementą iš atitinkamo (pirmo) pradinèsdauginamosios (4 žingsnis) eilutès elemento, gaunama: $\frac{2,0071}{0,3178}=6,3160$.

Surandamas jų aritmetinis vidurkis. Gaunama: $\frac{1}{6}(6,3160+6,2047+$ $6,2512+6,3056+6,3572+6,6166)=6,3419$.

Gaunama, kad didžiausia tikrinè reikšmè $\lambda_{\max }=6,34$.

Žinoma, kad atvirkštinès simetrinès $m$ eilès matricos didžiausia tikrinè reikšmè $\lambda_{\max } \geq m$. Šiuo atveju lyginimo matricos eilè arba lyginamų kriterijų skaičius $m=6$. Tuo pačiu 6,34 $>6$. Sąlyga yra tenkinama.

Dabar jau labai lengva apskaičiuoti suderinamumo indeksa, kuris apibrèžiamas taip:

$$
\begin{gathered}
C . I .=\frac{\lambda_{\max }-m}{m-1} ; \\
C . I .=\frac{\lambda_{\max }-m}{m-1}=\frac{6,3419-6}{6-1}=0,0684 .
\end{gathered}
$$

Matricos suderinamumas tuo geresnis, kuo mažesnè C.I. reikšmè. Idealiu atveju C.I. $=0$. 


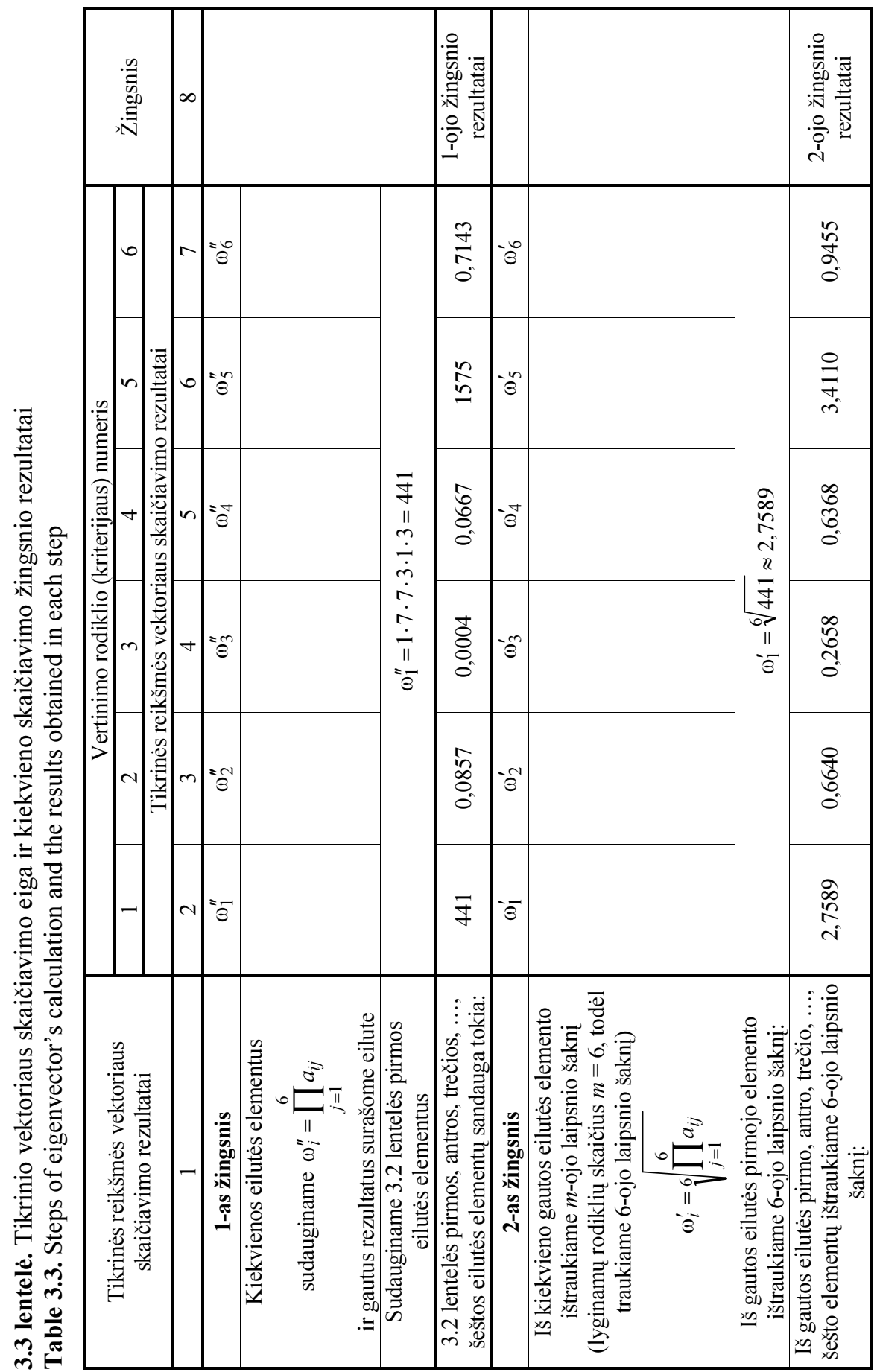




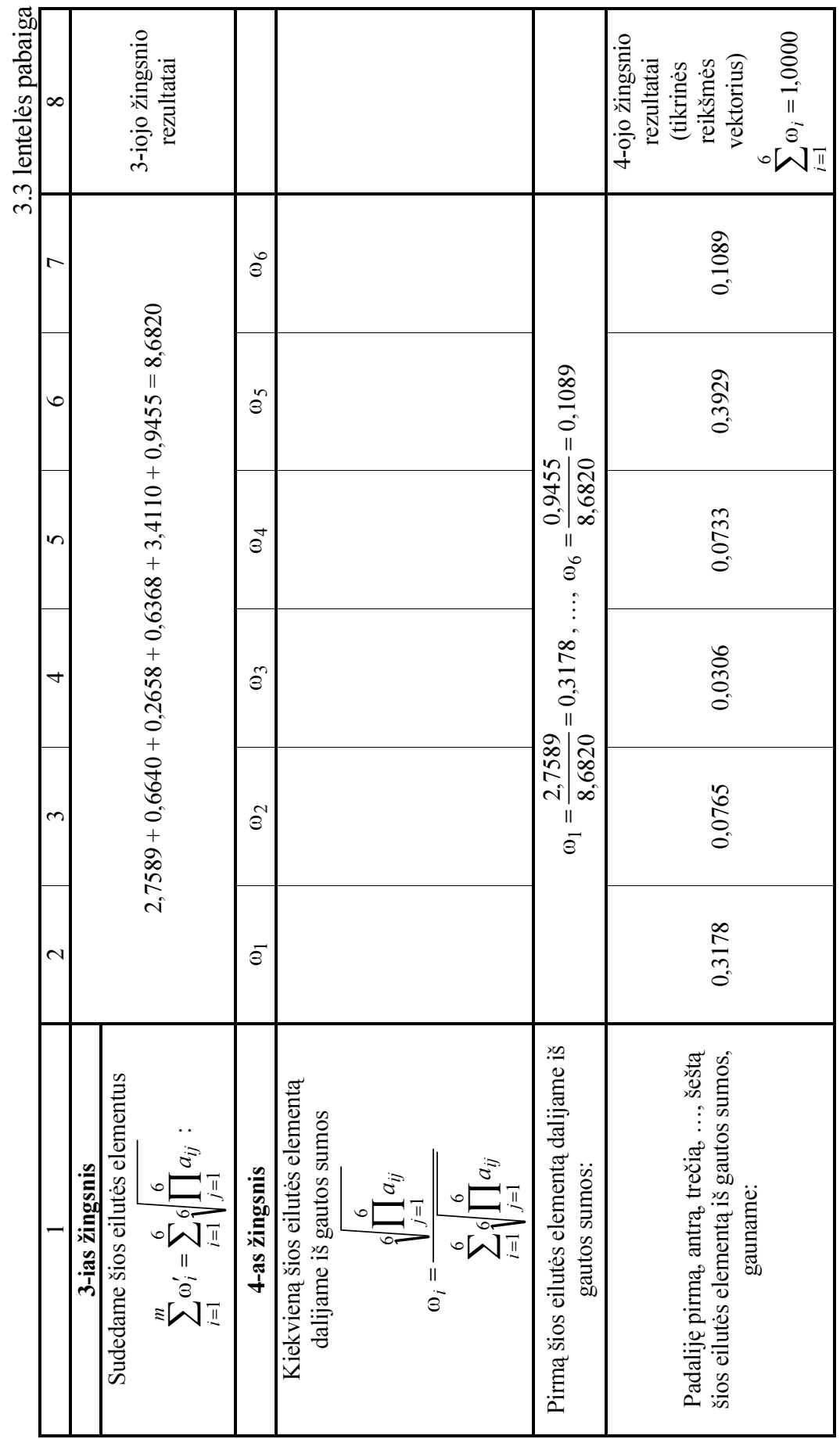


Matricos suderinamumo indekso C.I. ir atsitiktinio indekso vidurkio R.I., imamo iš lentelès (Saaty 1980), santykis vadinamas suderinamumo santykiu C.R., rodančiu matricos suderinamumo laipsnį:

$$
\begin{gathered}
C . R .=\frac{C . I .}{R . I .} \\
C . R .=\frac{C . I .}{R . I .}=\frac{0,0684}{1,24}=0,0551 .
\end{gathered}
$$

Matrica bus suderinta, jeigu santykio C.R. reikšmè mažesnè arba lygi 0,1 . Kadangi $0,0551<0,1$, matrica yra suderinta.

\subsubsection{Grupės respondentų ir ekspertų nuomonių suderinamumas}

TKVGK rodo atskiri kriterijai, kurių svarba nèra vienoda. Kriterijų, turinčių skirtingus mato vienetus ir bedimensius kriterijus, galima lyginti nustatant jų svarbą (reikšminguma) taikant ekspertų metodus. Ekspertinių vertinimų metodo esmè ta, kad jis leidžia racionaliai organizuoti ekspertu atliekamą problemos su kiekybiniu nuomonių ịvertinimu ir jų rezultatų apdorojimu analizę. Apibendrinta ekspertų grupès nuomonė imama kaip problemos sprendinys (sprendimo rezultatas). Jei reikia priimti sprendimą ekspertų vertinimų pagrindu, būtina ìvertinti ekspertų nuomonių suderinamumo laipsni. Labai svarbu nustatyti ekspertų nuomonių suderinamuma, taikant daugiakriterių vertinimų metodus (Завадскас 1987; Podvezko 2005; Saaty 1980b; Maskeliūnaitè et al. 2009a; Brauers et al. 2008). Ekspertų nuomonių suderinamumą rodo konkordancijos koeficientas.

Kendalo (1970) konkordancijos koeficiento ideja susieta su kiekvieno rodiklio (kriterijaus) rangų suma $R_{j}$ visų respondentų ar ekspertų atžvilgiu:

$$
R_{j}=\sum_{i=1}^{n} R_{i j}(j=1,2, \ldots, m)
$$

tiksliau, su dydžių $R_{j}$ nuokrypiu nuo bendro vidurkio $\bar{R}$ kvadratų suma $S$ (dispersijos analogas):

$$
S=\sum_{j=1}^{m}\left(R_{j}-\bar{R}\right)^{2}
$$

Vidutinis kiekvieno kriterijaus rangas $\bar{R}$ gaunamas jam suteiktų rangu sumą dalijant iš kriterijų skaičiaus: 


$$
\bar{R}=\frac{\sum_{j=1}^{m} R_{j}}{m} \text { arba } \bar{R}=\frac{\sum_{j=1}^{m} \sum_{i=1}^{n} R_{i j}}{m}=\frac{n(m+1)}{2},
$$

čia: $R_{i j}-i$-ojo respondento (eksperto) $j$-ajam kriterijui suteiktas rangas, $n$ - respondentu (ekspertu) skaičius $(i=1,2, \ldots, n) m$-kriterijų skaičius $(j=1,2, \ldots, m)$.

Jei $S$ yra reali kvadratų suma, apskaičiuota pagal (3.11) formulę, tai konkordancijos koeficientas $W$, kai nèra susietų rangų, apibrèžiamas gautos $S$ ir atitinkamos didžiausios $\mathrm{S}_{\max }$ santykiu (Kendall 1970; Евланов 1984):

$$
W=\frac{12 S}{n^{2} m\left(m^{2}-1\right)}=\frac{12 S}{n^{2}\left(m^{3}-m\right)} .
$$

Jei respondentų ar ekspertų nuomonès suderintos, konkordancijos koeficiento $W$ reikšmė yra arti vieneto, jei vertinimai labai skiriasi - $W$ reikšmė yra arti nulio.

Kiekvieno kriterijaus rangų $R_{i j}$ nuokrypių nuo vidutinio rango kvadratų sumą $S$ patogu skaičiuoti pagal formulę:

$$
S=\sum_{j=1}^{m}\left[\sum_{i=1}^{n} R_{i j}-\frac{1}{2} n(m+1)\right]^{2},
$$

čia: $m$ - kriterijų skaičius $(j=1,2, \ldots, m) ; n$ - respondentų (ekspertu) skaičius $(i=1,2, \ldots, n)$.

Atsitiktinio dydžio $S$ vertè skaičiuojama sudejjus visiems kriterijams nustatytas vertes.

Konkordancijos koeficientas gali būti taikomas praktikoje, jei nustatyta jo ribinè reikšmè, kada ekspertu vertinimus dar galima laikyti suderintais. M. Kendall įrodè (Кендэл 1975), kad jeigu objektu (kriteriju) skaičius $m>7$, konkordancijos koeficiento reikšmingumas gali būti nustatytas naudojant $\chi^{2}$ (chikvadrat) Pirsono kriterijų.

Atsitiktinis dydis

$$
\chi^{2}=W n(m-1)=\frac{12 S}{n m(m+1)},
$$

pasiskirstęs pagal $\chi^{2}$ skirstinị su $v=m-1$ laisvès laipsniu. Pagal pasirinktą reikšmingumo lygmeni $\alpha$ (praktikoje $\alpha$ reikšmè imama 0,05 arba dar griežtesnè $0,01)$ iš $\chi^{2}$ skirstinio lentelès su $v=m-1$ laisvès laipsniu randama kritinè reikšmè $\chi_{k r}^{2}=\chi_{v, \alpha}^{2}$. Jei apskaičiuota pagal (3.15) formulę $\chi^{2}$ reikšmė didesnè už $\chi_{k r}^{2}$, tai rodo, kad ekspertų (respondentu) vertinimai suderinti (Čekanavičius, Murauskas 2004). 
Kada lyginamų rodiklių (kriterijų) skaičius $m$ yra nuo 3 iki 7 , skirstini $\chi^{2}$ reikia taikyti atsargiai, nes skirstinio kritinè $\chi_{k r}^{2}$ vertè gali būti didesnè už apskaičiuota, nors ekspertų nuomonių suderinamumo lygis yra dar pakankamas. Tokiu atveju galima taikyti konkordancijos koeficiento tikimybines lenteles arba kritinių reikšmių $S$ lenteles (su $3 \leq m \leq 7$ ) (Podvezko 2005).

Mažiausia konkordancijos koeficiento $W_{\min }$ (Кремер 2003) reikšmè, kuriai esant galima teigti, kad visų $n$ respondentų ar ekspertų nuomonès apie iš $m$ lyginamų kriterijų sudaryto tiriamojo objekto kokybę su nustatytuoju (reikiamu) svarbumo lygmeniu $\alpha$ ir laisvès laipsniu $v=m-1$ yra suderintos, galima apskaičiuoti taikant šią formulę:

$$
W_{\text {min }}=\frac{\chi_{\alpha, v}^{2}}{n(m-1)},
$$

čia: $\chi_{\alpha, v}^{2}$ - kritinè Pirsono statistika, kurios vertè randama lenteleje (Montgomery 2008), imant laisvès laipsni $v=m-1$ ir reikšmingumo lygmeni $\alpha$.

Kai objekto kokybė vertinama adityviniu matematiniu modeliu, pagal kurị apskaičiuojamas jo KKVR, leidžiantis vienu skaičiumi nustatyti jo kokybę ir ją lyginti su analogiškais kitais objektais, tai šiam tikslui patogu naudoti ne kriterijų vidutinius rangus $\bar{R}$, kurie nerodo, kiek vienas už kitą rangai svarbesni, bet jų svarbumo rodiklius $Z_{j}$.

Ekspertų vertinamo objekto kokybės kriterijų svarbumas juos normalizuojant (jų sumą prilyginant vienetui) gali būti nustatomas skaičiuojant kiekvieno kriterijaus svarbumo rodikli $Z_{j}$ pagal formulę (Sivilevičius 2011b):

$$
Z_{j}=\frac{(m+1)-\bar{R}_{j}}{\sum_{j=1}^{m} \bar{R}_{j}},
$$

čia: $m$ - objekto kokybę (savybes) rodančių kriteriju (rodiklių) skaičius; $\bar{R}_{j}-j$ ojo kriterijaus vidutinis rangas, apskaičiuotas pagal (3.12) formulę.

\subsubsection{Respondentų (keleivių) nuomonių suderinamumo skaitinis pavyzdys}

Konkordancijos koeficientui skaičiuoti tinka tik respondentų ar ekspertų rodiklių rangavimas. Jei respondentų ar ekspertų vertinimai buvo bet kokio kitokio pavidalo, juos reikia ranguoti. Rangavimas yra procedūra, kai pačiam svarbiausiam rodikliui suteikiamas rangas, lygus vienetui, antram pagal svarbumą - rangas du ir t. t.

Kriterijų, susietų su kelionès kaina (kriterijų grupė C), svarbos rangavimas, dešimties respondentų nuomone, pateiktas 3.4 lentelèje. 
3.4 lentelè. Kriterijų, susietų su kelionès kaina, svarbos rangavimas pagal respondentų nuomonę

Table 3.4. Ranking of ticket price-related criteria in respondent questionnaires

\begin{tabular}{|c|c|c|c|c|c|c|c|c|c|c|c|}
\hline \multirow{2}{*}{ Kriterijus } & \multicolumn{10}{|c|}{ Respondentas } & Rangu \\
& \multicolumn{1}{|c|}{1} & 2 & 3 & 4 & 5 & 6 & 7 & 8 & 9 & 10 & suma \\
\hline 1 & 1 & 1 & 1 & 2 & 1 & 1 & 3 & 1 & 3 & 4 & 18 \\
\hline 2 & 3 & 5 & 2 & 4 & 4 & 5,5 & 3 & 2 & 4,5 & 3 & 36 \\
\hline 3 & 4 & 6 & 4,5 & 6 & 6 & 5,5 & 6 & 4 & 6 & 6 & 54 \\
\hline 4 & 5 & 3 & 4,5 & 5 & 4 & 3 & 3 & 5 & 2 & 2 & 36,5 \\
\hline 5 & 2 & 2 & 6 & 1 & 2 & 2 & 3 & 3 & 1 & 1 & 23 \\
\hline 6 & 6 & 4 & 3 & 3 & 4 & 4 & 3 & 6 & 4,5 & 5 & 42,5 \\
\hline Suma & 21 & 21 & 21 & 21 & 21 & 21 & 21 & 21 & 21 & 21 & 210 \\
\hline
\end{tabular}

Kriterijų, susietų su kelionès kaina, svarbos rangavimo, ketvirtojo respondento (keleivio) nuomone, pavyzdys pateiktas 3.5 lentelëje.

3.5 lentelè. Kriterijų, susietų su kelionės kaina, svarbos rangavimas pagal ketvirtojo respondento (keleivio) nuomonę

Table 3.5. The ranks assigned by respondent (passenger) No 4 to the criteria describing ticket price according to their significance

\begin{tabular}{|c|c|c|}
\hline Kriterijus & Kriterijaus svoris & Rangas \\
\hline 1 & 0,3178 & 2 \\
\hline 2 & 0,0765 & 4 \\
\hline 3 & 0,0306 & 6 \\
\hline 4 & 0,0733 & 5 \\
\hline 5 & 0,3929 & 1 \\
\hline 6 & 0,1089 & 21 \\
\hline Suma & 1,0000 & \\
\hline
\end{tabular}

Visų kriterijų bendra rangų suma yra $\sum_{j=1}^{m} R_{j}=210$ (paskutinių 3.4 lentelès elementų suma). Kriterijų rangų vidurkis $\bar{R}=35$, apskaičiuotas pagal (3.12) formulę arba skaičiuojant kitaip, $\bar{R}=210 / 6=35$. Kvadratų nuokrypių suma yra $S=853,5$.

Kriterijų, susietų su kelionès kaina, grupès respondentų (dešimties keleivių) konkordancijos koeficientas $W$, apskaičiuotas pagal (3.13) formulę, yra $W=0,49$.

Naudojant 3.4 lentelès duomenis ir skaičiuojant pagal (3.15) formulę, gaunama $\chi^{2}=24,39$. Apskaičiuotas $\chi^{2}=24,39$, o kritine $\chi_{\alpha, v}^{2}$ reikšmé, paimta iš 
skirstinio lentelès su $v=6-1=5$ laisvès laipsniu ir reikšmingumo lygmeniu $\alpha=0,050$, yra 11,07. Empirinè reikšmè $\chi^{2}=24,39$ yra didesnè už kritinę, todèl respondentų nuomonès gerai suderintos.

Mažiausia konkordancijos koeficiento $W_{\min }$ verte yra apskaičiuojama pagal (3.16) formulę (Айвазян, Мхитарян 2001), kuriai esant su reikšmingumo lygmeniu $\alpha=0,050$ ir laisvès laipsnių skaičiumi $v=m-1=6-1=5$ galima teigti, kad respondentų nuomonès suderintos: $W_{\min }=0,22<0,49$. Anketų A, B, C, D (2.4 pav.) grupių kriterijų ir respondentų bei ekspertų kategorijų (10 keleivių, 11 traukini aptarnaujančio personalo ir 3 administracijos darbuotojų) konkordancijos koeficiento $W$, kritinès reikšmès $\chi_{\alpha, v}^{2}$ (paimtos iš skirstinio lentelès su atitinkamu laisvès laipsniu ir reikšmingumo lygmeniu $\alpha=0,050$ ) ir mažiausio konkordancijos koeficiento $W_{\min }$ reikšmès pateiktos 3.6 lentelèje.

3.6 lentelè. Anketų A, B, C, D grupių kriterijų, respondentų (K) ir ekspertų (P, A) kategorijų konkordancijos koeficiento $W$, apskaičiuotos $\chi^{2}$ vertès ir konkordancijos koeficiento $W_{\min }$ reikšmès

Table 3.6. The value of the concordance coefficient $W$, the calculated value $\chi^{2}$ and the lowest value of the concordance coefficient $W_{\min }$ for the criteria of the groups A, B, C, $\mathrm{D}$, obtained in the questionnaires elicited from respondents $(\mathrm{K})$ and experts $(\mathrm{P}, \mathrm{A})$

\begin{tabular}{|c|c|c|c|c|c|c|c|c|c|c|c|c|}
\hline \multirow{4}{*}{$\begin{array}{l}\text { Respondentų } \\
\text { ar ekspertų } \\
\text { kategorija* }\end{array}$} & \multicolumn{12}{|c|}{ Kategoriju grupės } \\
\hline & \multicolumn{3}{|c|}{ A } & \multicolumn{3}{|c|}{$\mathrm{B}$} & \multicolumn{3}{|c|}{$\mathrm{C}$} & \multicolumn{3}{|c|}{$\mathrm{D}$} \\
\hline & \multicolumn{12}{|c|}{ Reikšmė } \\
\hline & $W$ & $\chi^{2}$ & $W_{\min }$ & $W$ & $\chi^{2}$ & $W_{\min }$ & $W$ & $\chi^{2}$ & $W_{\min }$ & $W$ & $\chi^{2}$ & $W_{\min }$ \\
\hline $\mathrm{K}$ & 0,33 & 49,03 & 0,17 & 0,38 & 68,49 & 0,16 & 0,49 & 24,39 & 0,22 & 0,45 & 31,75 & 0,20 \\
\hline $\mathrm{P}$ & 0,21 & 35,10 & 0,15 & 0,36 & 71,54 & 0,15 & 0,42 & 22,84 & 0,20 & 0,47 & 36,05 & 0,18 \\
\hline \multirow[t]{2}{*}{ A } & 0,73 & 32,77 & 0,56 & 0,82 & 44,49 & 0,53 & 0,83 & 12,52 & 0,74 & 0,49 & 10,39 & 0,67 \\
\hline & \multicolumn{3}{|c|}{25,00} & \multicolumn{3}{|c|}{28,87} & \multicolumn{3}{|c|}{11,07} & \multicolumn{3}{|c|}{14,07} \\
\hline
\end{tabular}

"Respondentų ir ekspertų kategorijų žymenys: $\mathrm{K}$ - keleiviai, $\mathrm{P}$ - traukini aptarnaujantis personalas, A - administracijos darbuotojai

Iš lentelès matyti, kad A (administracijos darbuotojų) kategorijos ekspertų nuomonès dèl D grupès kriterijų svarbos yra nesuderintos (3.3.d pav. ir 3.6 lentelè), nes apskaičiuotas $\chi^{2}=10,39$, o kritine $\chi_{\alpha, v}^{2}$ reikšmè, paimta iš skirstinio lentelès su $v=8-1=7$ laisvès laipsniu ir reikšmingumo lygmeniu $\alpha=0,050$, yra 14,07. Empirinè reikšmè $\chi^{2}=10,39$ yra mažesnè už kritinę $\chi_{\alpha, v}^{2}=14,07$, todèl ekspertų nuomonès nesuderintos. Mažiausio konkordancijos koeficiento reikšmė $W_{\min }=0,67$ yra didesnè už konkordancijos koeficientą $W=0,49$. 


\subsection{Respondentų ir ekspertų anketų analizè}

Skyriuje pateikta keleivių, traukini aptarnaujančio personalo ir AB „Lietuvos geležinkeliai" Keleivių vežimo direkcijos administracijos darbuotojų nuomonių lyginamoji kriterijų svarbos analizè. Kriterijų svarbos nustatymas ir rangavimas pagal keleivių nuomonę pateiktas B priede, traukini aptarnaujančio personalo $\mathrm{C}$ priede, o AB ,Lietuvos geležinkeliai“ Keleivių vežimo direkcijos administracijos darbuotoju - D priede.

\subsubsection{Keleivių nuomonė apie kriterijų svarbą}

Tyrimas parodè, kad keleivių nuomonè gerai suderinta. Kriterijų grupès A1-16 svarbos, keleivių nuomone, stulpeline diagrama pavaizduota 3.1 paveiksle. Matyti, kad keleiviams labai svarbūs yra (2.4 ir 3.1a pav.) A2, A7 ir A6, o nesvarbūs A13, A1 ir A16 kriterijai. Manoma, kad keleiviams A2 kriterijus yra svarbus del to, kad nuo jo priklauso kelionès trukmé (kada bus pasiektas kelionės tikslas). A7 ir A6 kriterijai lemia kelionès patogumą. Tikètina, kad keleiviams nesvarbus yra A13 kriterijus, nes sklindantys garsai malonūs ne visiems keleiviams: nepatinkanti ar per garsiai skambanti muzika gali erzinti. Kai kurie keleiviai nori ilsètis, skaityti knygą. Tai, kad keleiviams nesvarbus A1 kriterijus, šiek tiek mums netikètas rezultatas, tačiau keleiviai, matyt, yra ipratę prie traukinio judejjimo netolygumo, todèl priima tai kaip savaime suprantamą ir neišvengiamą reiškini.

Iš diagramos (3.1b pav.) matyti, kad keleiviams labai svarbūs B1, B13 ir B15 kriterijai. Visiškai nesvarbūs yra B11, B12 ir B9 kriterijai. Labai svarbu, kad traukiniai vyktu pagal numatytą grafiką. Vèluojant traukiniui gali žlugti tolesni keleivio planai (gali pavèluoti į kitą traukini, lèktuvą ir t. t.). B13 kriterijus svarbus, nes kelionès metu keleivis gali prarasti savo daiktus ir dokumentus, o tai suteiktų jam papildomų rūpesčių, sugadintų nuotaiką. Jeigu vizas būtų galima isigyti pasienio punkte (B15 kriterijus) (2.4 pav.), būtų išspręsta keleivių iš traukinio išlaipinimo pasienio stotyje problema. Pavyzdžiui, iš Lietuvos i Rusiją vykstantis keleivis ir neturintis Baltarusijos tranzitinès vizos iš traukinio Baltarusijos pasienio punkte yra išlaipinamas ir grąžinamas atgal, i Lietuvą. Keleivis priverstas nutraukti kelionę ir keisti savo planus, sugadinta jo nuotaika. Taigi, pirkti vizą pasienio punkte būtų labai patogu. Keleiviams nesvarbus B11 kriterijus, nes suvenyrų galima nusipirkti mieste arba geležinkelio stotyje. Buvo minèta, kad ne visada ir ne visiems norisi klausytis muzikos traukinyje. Informaciją apie kelionę keleiviui visada gali suteikti vagono palydovas arba traukinio viršininkas, galbūt todèl keleiviams nesvarbus yra B12 kriterijus. Manoma, kad B9 kriterijus nèra populiarus dèl to, kad daugelị keleiviu pasitinka atvykimo stotyje arba jis taksi gali iškviesti pats. Keleiviui, kuriam reikia važiuoti toliau, važiuoti taksi yra brangu ir dèl to jis renkasi kitą transporto priemonę. 


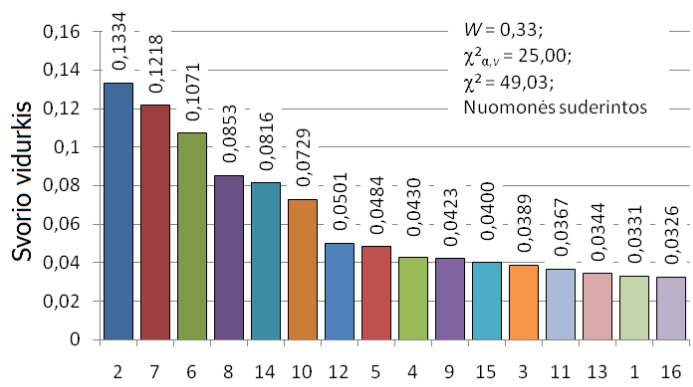

a)

Kriterijaus numeris anketoje

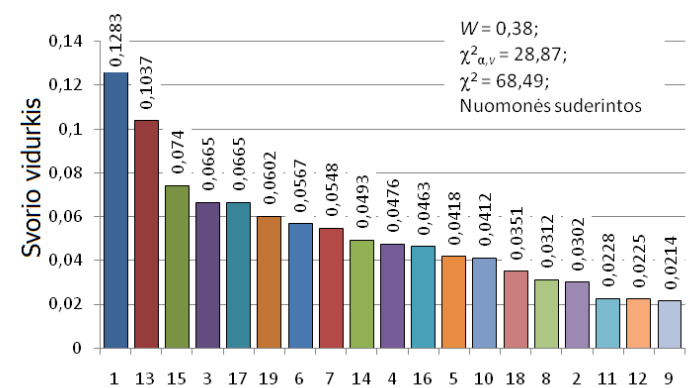

b)

Kriterijaus numeris anketoje

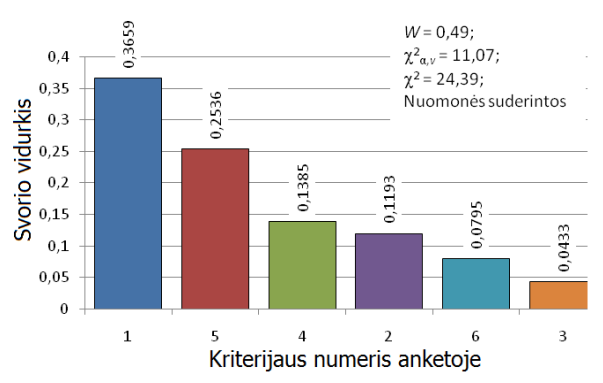

c)

3.1 pav. Kriterijų, susietų su: a - traukinio elementų ir geležinkelio kelio technine būkle (A grupè), b - kelionès traukiniu proceso organizavimu ir technologija (B grupè), $\mathrm{c}$ - kelionès kaina ( $\mathrm{C}$ grupè), $\mathrm{d}$ - kelionès traukiniu saugumu (D grupè), svarbos, keleivių (K kategorija) nuomone, stulpelinė diagrama

Fig. 3.1. The data on the evaluation of the significance of the grouped criteria describing the quality of passenger transportation by rail elicited from the passengers of the train (respondents of category K): $\mathrm{a}$ - the technical state of the train parts and the railway

(group A); b - denotes the organization and technology of railway trip (group); $\mathrm{c}$ - the ticket price (group C); d - railway trip safety (group D)

Iš stulpelinès diagramos (3.1c pav.), kurioje pavaizduota C1-6 kriterijų grupès svarba keleivių nuomone, matyti, kad keleiviams svarbūs C1, C5 ir C4 kriterijai 
(2.4 pav.). Keleiviams nesvarbūs C2, C6 ir C3 kriterijai. Manoma, kad keleiviams svarbūs C1, C5 ir C4 kriterijai, nes jie sudaro didžiają kelionès išlaidų dali. C1 kriterijus yra aktualus dažnai, pavyzdžiui, verslo reikalais traukiniu keliaujantiems keleiviams. C2 kriterijus nèra toks svarbus, nes ne visi keleiviai kelionės metu apsilanko restorano vagone. C6 kriterijus taip pat nesvarbus, nes bilietai į ši vagoną brangūs. Dauguma keleivių renkasi pigesnius žemesnès klasės vagonus. Laikraščių ir žurnalų kaina (C3 kriterijus) traukinyje yra tokia pati kaip ir spaudos kioskuose. Kai kurie dienraščiai duodami keleiviams nemokamai. Be to, dažnas i kelionę pasiima knyga, todèl traukinyje gali išsiversti be spaudos.

Iš stulpelinès diagramos (3.1d pav.), kurioje pavaizduota D1-8 kriteriju grupès svarba keleivių nuomone, matyti, kad keleiviams svarbūs D7, D1 ir D2 kriterijai (2.4 pav.). Keleiviams nesvarbūs D5, D3 ir D8 kriterijai. Manoma, kad keleiviams svarbus D7 kriterijus, nes rankiniais stabdžiais, kai neveikia automatiniai stabdžiai, galima sustabdyti traukini. Stabdu traukinys stabdomas, pavyzdžiui, gaisro atveju, suveikus ašidèžių perkaičio signalizacijai ir kt. D1 kriterijus užtikrina priešgaisrinę sauga. Traukinyje pasitaiko nudegimų, susižeidimų atvejų. Todèl manoma, kad D2 kriterijus svarbus keleiviams. Ne visi turi savo medikamentų. Tai, kad keleiviams nelabai svarbūs D5, D3 ir D8 kriterijai, rezultatai šiek tiek netikèti. D5 kriterijus užtikrina saugų keleivių evakavimą gaisro ar kitu nenumatytu ir keleivių sveikatai ar gyvybei pavojingu atveju.

Galbūt keleiviai mano, jog esant būtinybei galima evakuotis pro duris ir langus, todèl avariniai išèjimai nèra svarbūs. Iš stulpelinès diagramos ( $3.1 \mathrm{~d}$ pav.) matyti, kad keleiviai savimi pasitiki ir mano, jog rimtos medikų ar policijos pareigūnu pagalbos kelioneje neprireiks, kad visas kelionèje kilusias problemas gali išspręsti patys arba traukini aptarnaujantis personalas. İdomu tai, kad iš 10 anketas teisingai užpildžiusių keleivių, 7 vyrai ir tik 3 moterys. Galbūt tai lèmé tokius rezultatus vyrai nenoriai lankosi pas medikus ir nenori turèti reikalų su policijos pareigūnais.

\subsubsection{Traukini aptarnaujančio personalo nuomonè apie kriteriju svarbą}

Tyrimui buvo panaudotos tos pačios struktūros anketos (2.4 pav.). Tyrimas parodè, kad traukini aptarnaujančio personalo nuomonè gerai suderinta (3.2 pav.).

Kriteriju grupès A1-16 svarbos, traukini aptarnaujančio personalo nuomone, stulpelinè diagrama pavaizduota 3.2a paveiksle. Iš stulpelinès diagramos matyti, kad traukini aptarnaujantis personalas aukščiausius rangus skyrè A6, A8 ir A7, o žemiausius - A1, A12 ir A3 kriterijams (2.4 ir 3.2a pav.). Manoma, jog traukini aptarnaujančio personalo darbuotojai nesugebejo atsiriboti nuo savo darbo ypatumų ir vertinti kriterijus keleivio požiūriu. Jiems svarbu kelionès patogumas, kuris priklauso nuo A6, A8 ir A7 kriterijų, tačiau visiškai nesvarbus A1 kriteri- 
jus, turintis itakos traukinio greičiui (kelionès trukmei), nes jie yra savo darbo vietoje (Maskeliūnaitè, Sivilevičius 2009b).

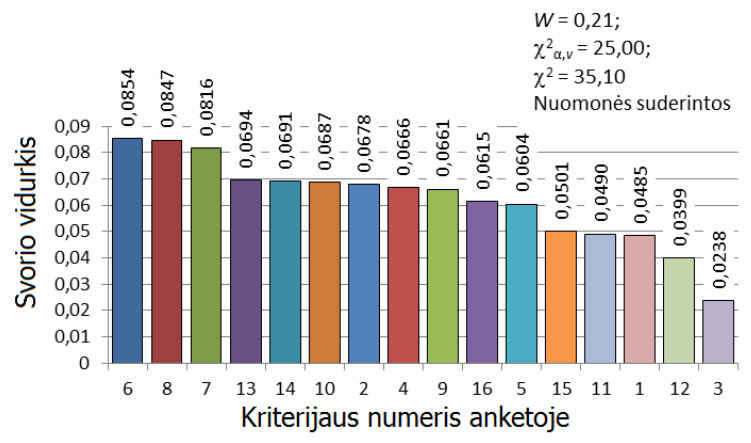

a)
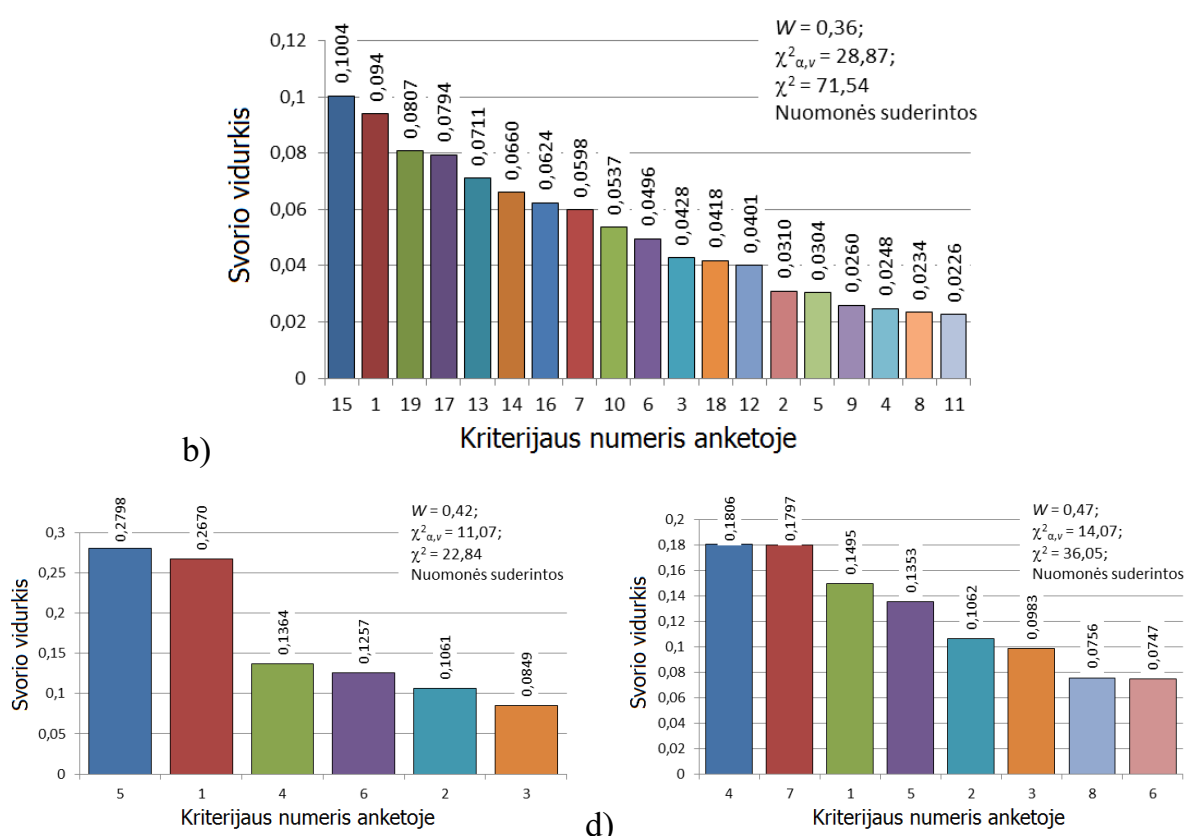

3.2 pav. Kriterijų, susietų su: a - traukinio elementų ir geležinkelio kelio technine būkle (A grupè), $\mathrm{b}$ - kelionès traukiniu proceso organizavimu ir technologija (B grupè), $\mathrm{c}$ - kelionès kaina (C grupè), $\mathrm{d}$ - kelionès traukiniu saugumu ( $\mathrm{D}$ grupè), svarbos, traukini aptarnaujančio personalo (P kategorija) nuomone, stulpelinè diagrama

Fig. 3.2. The data on the evaluation of the significance of the grouped criteria describing the quality of passenger transportation by rail elicited from the administration staff (category of experts P): a - the technical state of the train parts and the railway (group

$\mathrm{A}) ; \mathrm{b}$ - denotes the organization and technology of railway trip (group B); $\mathrm{c}$ - the ticket price (group C); $\mathrm{d}$ - railway trip safety (group D) 
Kriteriju grupės B1-19 svarbos, traukini aptarnaujančio personalo nuomone, stulpelinè diagrama pavaizduota $3.2 \mathrm{~b}$ paveiksle. Iš diagramos matyti, kad traukini aptarnaujančiam personalui yra svarbūs B15, B1 ir B19 kriterijai, o B4, B8 ir B11 kriterijai yra nereikšmingi (2.4 ir 3.2b pav.). Manoma, kad B15 ir B1 kriterijai traukini aptarnaujančio personalo darbuotojams svarbūs dèl to, kad jiems dažnai tenka stebèti, kaip pasienio punkte iš traukinio yra išlaipinami keleiviai, kurių dokumentai neatitinka nustatytų reikalavimų. Keleivis priverstas nutraukti kelionę: sugadinta jo nuotaika, jis turi keisti savo planus. Daug nepatogumų keleiviai patiria ir vèluojant traukiniui. B19 kriterijus yra svarbus traukini aptarnaujančio personalo darbuotojams, nes muitinès ir pasienio pareigūnų kompetencija, objektyvumas ir bendravimo kultūra yra tarsi šalies, kuriai jie atstovauja, vizitine kortelè. Šie pareigūnai pirmieji reprezentuoja savo šali. Traukini aptarnaujantiems darbuotojams nesvarbūs yra B4, B8, B11 kriterijai. Manoma, kad tai yra darbo ypatumų itaka, nes būtent palydovai yra šių paslaugų vykdytojai arba kriterijus visiškai neturi įtakos paties darbuotojo patogumui, pavyzdžiui, B8 kriterijus (Maskeliūnaitè, Sivilevičius 2009b).

Kriteriju grupés C1-6 svarbos, traukinị aptarnaujančio personalo nuomone, stulpelinè diagrama pavaizduota $3.2 \mathrm{c}$ paveiksle. Matyti (2.4 ir 3.2c pav.), kad traukini aptarnaujantiems darbuotojams svarbūs C5, C1 ir C4 kriterijai, nes jie sudaro didžiają keleivio kelionès išlaidų dalį. Visiškai nesvarbūs yra C6, C2 ir C3 kriterijai.

Kriteriju grupès D1-8 svarbos nustatymo, traukini aptarnaujančio personalo nuomone, stulpelinè diagrama pavaizduota $3.2 \mathrm{~d}$ paveiksle. Manoma (2.4 ir $3.2 \mathrm{~d}$ pav.), kad traukinį aptarnaujantiems darbuotojams svarbūs D4, D7 ir D1 kriterijai todèl, kad jie, kaip šios srities specialistai, ivvertino šių kriterijų svarbumą kelionès saugumui. Visiškai nesvarbūs yra D3, D8 ir D6 kriterijai, nes gedimus, ivykusius kelionès metu, šalina traukinio mechanikas elektrikas ir jie didelès reikšmès kelionès saugumui neturi, todèl traukini aptarnaujantis personalas vertindamas neteikia jiems didelès reikšmès (Maskeliūnaite, Sivilevičius 2009b). Prireikus nèra keblumų $\mathfrak{i}$ traukinį iškviesti greitają medicinos pagalbą ar policijos pareigūnus.

\subsubsection{Administracijos darbuotojų nuomonè apie kriterijų svarbą}

Buvo nustatyta A, B, C ir D grupių kriterijų (2.4 pav. ir 3.3 pav.) svarba AB „Lietuvos geležinkeliai“ Keleivių vežimo direkcijos administracijos darbuotojų nuomone. Tyrimas parodè, kad administracijos darbuotojų nuomonès dèl A, B ir C grupių kriterijų gerai suderintos (3.3a, b, c pav.), nesuderintos nuomonès dèl D grupès kriterijų svarbos (3.3d pav.). 


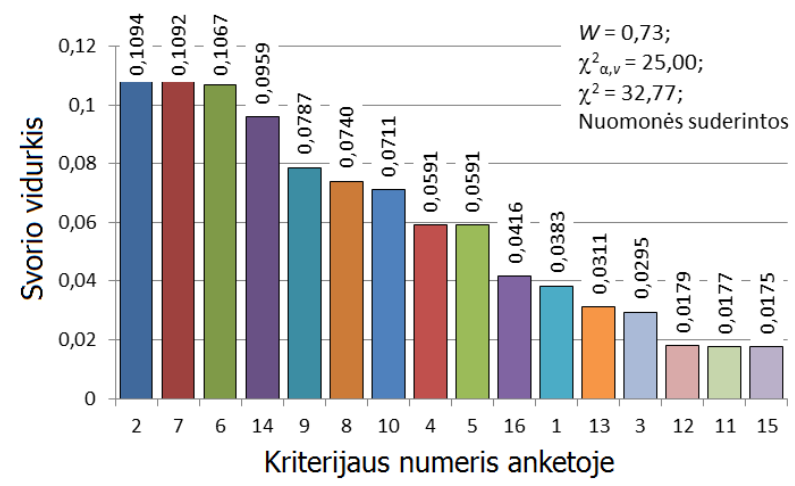

a)
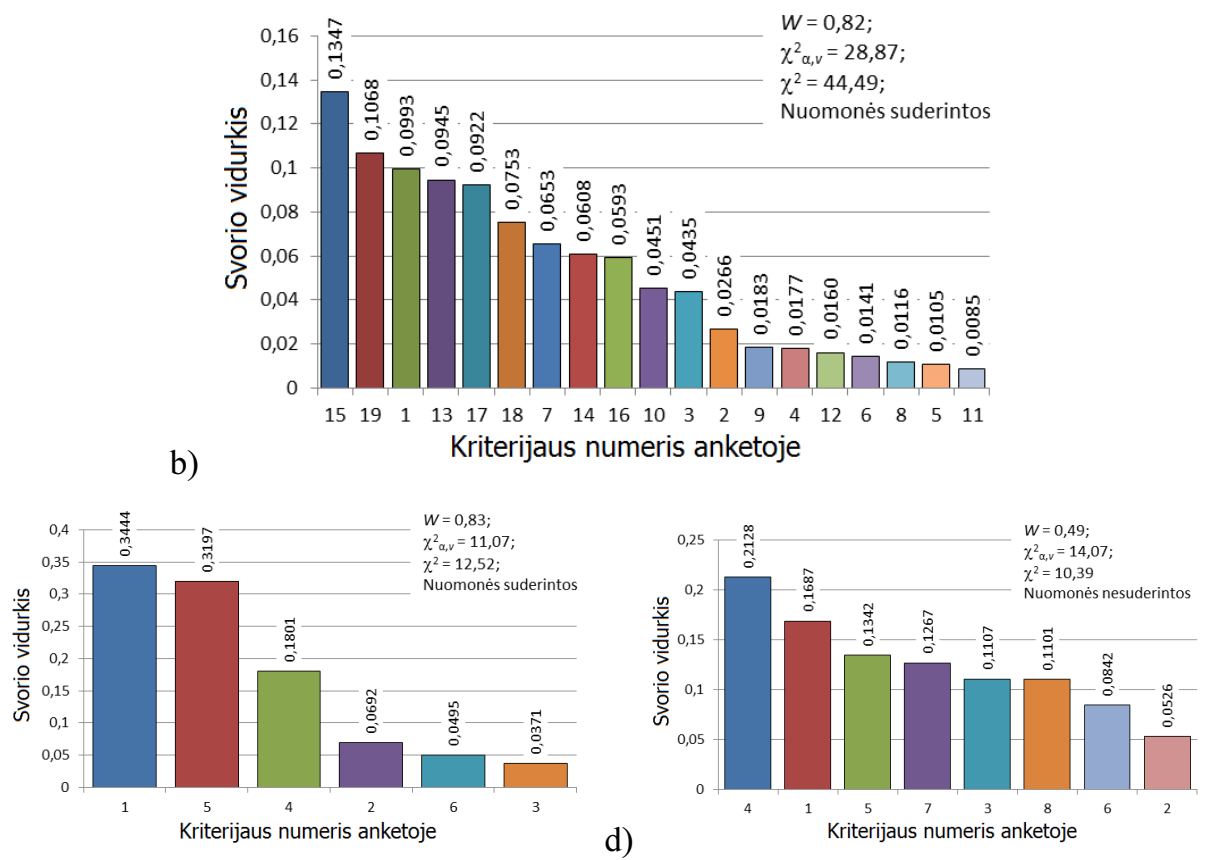

3.3 pav. Kriterijų, susietų su: a - traukinio elementų ir geležinkelio kelio technine būkle (A grupè), b - kelionès traukiniu proceso organizavimu ir technologija (B grupè), $\mathrm{c}$ - kelionès kaina (C grupè), d - kelionès traukiniu saugumu (D grupè), svarbos, administracijos darbuotojų (kategorija A) nuomone, stulpeliné diagrama

Fig. 3.3. The data on the evaluation of the significance of the grouped criteria describing the quality of passenger transportation by rail elicited from the administration staff (category of experts A): a - the technical state of the train parts and the railway (group A); b - denotes the organization and technology of railway trip (group B); $\mathrm{c}$ - the ticket price (group C); d - railway trip safety (group D) 
Kriteriju grupės A1-16 svarbos, administracijos darbuotojų nuomone, stulpelinè diagrama pavaizduota 3.3a paveiksle. Matyti, kad administracijos darbuotojams svarbūs A2, A7, A6 kriterijai, nuo kurių labai priklauso keleivių vežimo geležinkeliais kokybė. Kaip neesminius dalykus administracijos darbuotojai ivertino A12, A11 ir A15 kriterijus. Kadangi tarptautinių maršrutų traukiniuose yra rūkyti skirtos vietos, keleiviui leidžiama nemokamai vežti išardytą (nuimtais ratais) ir supakuotą dvirati, o minkštuosiuose dviviečiu kupe vagonuose yra irengti skubaus palydovo iškvietimo mygtukai, galbūt todèl administracijos darbuotojai neteikè šiems kriterijams reikšmès.

Administracijos darbuotojams svarbūs B15, B19, B1 kriterijai (2.4 ir $3.3 \mathrm{~b}$ pav.). Šie ekspertai, kaip turintys patirtị specialistai, supranta, kad šie kriterijai yra svarbūs keleivių vežimų kokybei. Nereikšmingais ekspertai laiko B8, B5 ir B11 kriterijus.

Kriteriju grupès C1-16 svarbos, administracijos darbuotojų nuomone, stulpeliné diagrama pavaizduota $3.3 \mathrm{c}$ paveiksle. Čia svarbiausi, administracijos darbuotojų nuomone, yra C1, C5, C4 (2.4 ir 3.3c pav.) kriterijai, lemiantys keleivio kelionès išlaidas, nesvarbūs, jų nuomone, yra C2, C6, C3 kriterijai.

Kriteriju grupès D1-8 svarbos nustatymo, administracijos darbuotojų nuomone, stulpeliné diagrama pavaizduota $3.3 \mathrm{~d}$ paveiksle. Matyti, kad administracijos darbuotojams svarbūs D4, D1, D5 kriterijai, nuo kurių priklauso kelionès saugumas. Kaip neesminius dalykus administracijos darbuotojai įvertino D8, D6 ir D2 kriterijus, tačiau, kaip jau buvo minèta, administracijos darbuotojų nuomonès dèl D grupès kriterijų svarbos yra nesuderintos. Galbūt ekspertams kriterijams vertinti pritrūko kruopštumo, loginio mąstymo, o gal kompetencijos.

\subsubsection{Trijų kategorijų tyrime dalyvavusių respondentų ir ekspertų lyginamoji nuomonių analizè}

Susisteminus visus TKVGK kriterijus (2.4 pav.), taikant AHP metodą buvo apklausti trijų kategorijų respondentai ir ekspertai: traukiniu važiuojantys keleiviai (K kategorija), traukini aptarnaujantis personalas (P kategorija) ir administracijos darbuotojai (A kategorija). Pagal sudarytą algoritmą (3.4 pav.) respondentai ir ekspertai anketose tarpusavyje lygino kiekvienos grupès kriterijus, nustatydami vieno lygio hierarchijos rodiklių svorius (reikšmingumus) aukštesnio lygio atžvilgiu arba hierarchiškai nestrūktūrizuotų rodiklių atžvilgiu. Apskaičiuota kiekvienos anketos didžiausia tikrinè reikšme $\lambda_{\max }$ (largest eigenvalue), suderinamumo indeksas C.I. (consistency index) ir suderinamumo santykis C.R. (consistency ratio). Anketos su prieštaringais vertinimais buvo atmestos. 


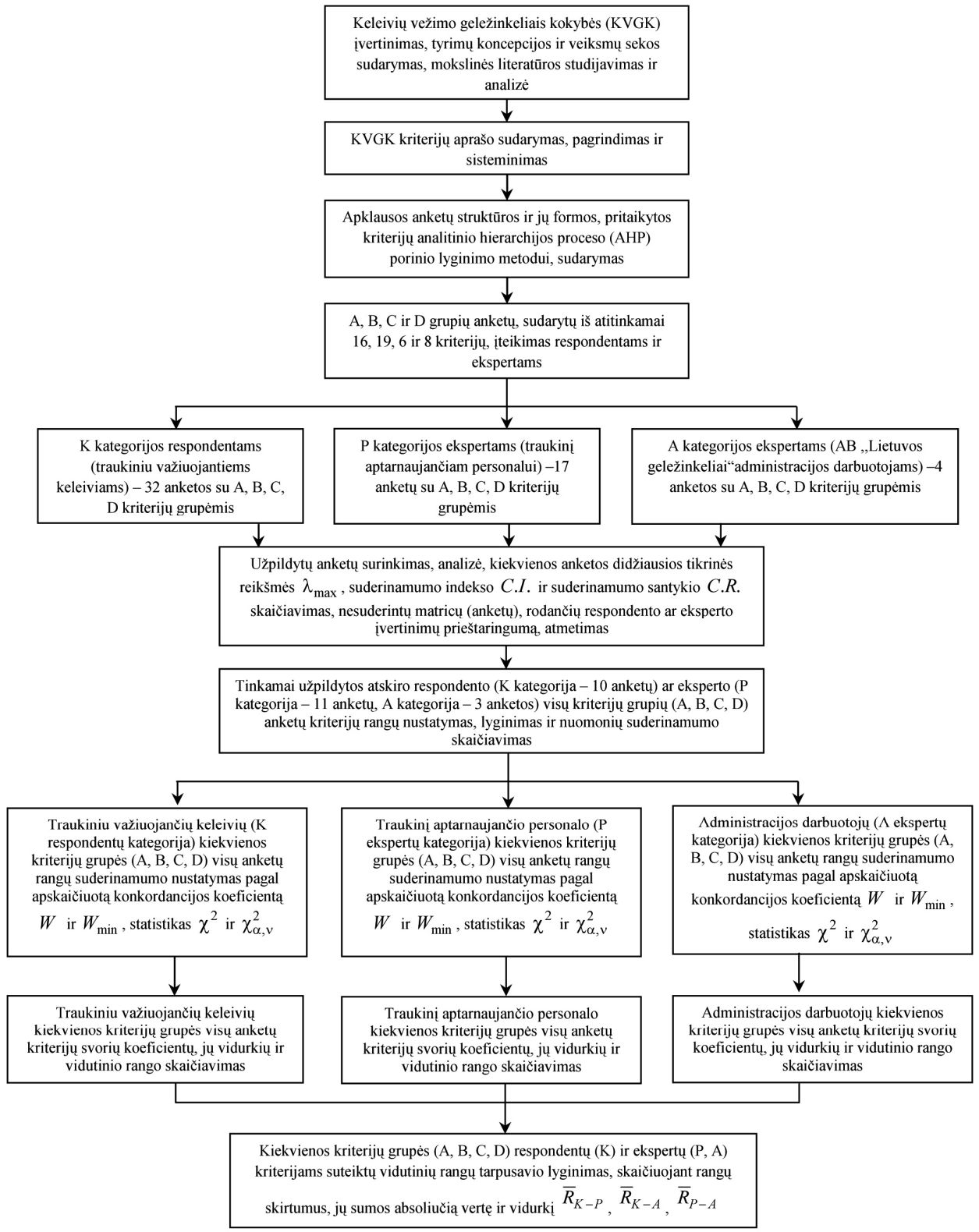

3.4 pav. Keleivių vežimo geležinkeliais kokybès (KVGK) tyrimo algoritmas

Fig. 3.4. The algorithm for evaluating the railway trip quality 
Visų trijų tyrime dalyvavusių kategorijų $(\mathrm{K}, \mathrm{P}, \mathrm{A})$ respondentų ir ekspertų nuomonių apie A grupés $j$-ojo kriterijaus svarbą rodo vidutinis svorio koeficientas $\bar{Q}_{A j}$, kuris apskaičiuojamas pagal formulę:

$$
\bar{Q}_{A j}=\frac{\sum_{z=1}^{3} Q_{A j z}}{3}=\frac{Q_{A j K}+Q_{A j P}+Q_{A j A}}{3},
$$

čia: $Q_{A j z}-$ A kriterijų (anketų) grupei $z$-osios kategorijos respondentų (ekspertu) $(z=1, \ldots, N) j$-ajam kriterijui suteiktas svorio koeficientas, $(j=1, \ldots, m) ; Q_{A j K}-$ keleivių suteiktas A kriterijų grupés $j$-ojo kriterijaus svoris; $Q_{A j P}-$ traukini aptarnaujančio personalo suteiktas A kriterijų grupés j-ojo kriterijaus svoris; $Q_{A j A}-$ administracijos darbuotojų suteiktas A kriterijų grupès $j$-ojo kriterijaus svoris.

Kitu grupių (B, C, D) kriterijų vidutiniai svorio koeficientai $\bar{Q}_{B j}, \bar{Q}_{C j}, \bar{Q}_{D j}$ buvo apskaičiuoti pagal analogiškas formules (3.7 lentelè).

Atlikus trijų kategorijų keleivių vežimų (kelionès traukiniu) vertintojų analizę, matyti, kad keleiviams ir administracijos darbuotojams svarbūs (2.4 ir 3.1a, 3.3a pav.) A2, A7, A6 kriterijai. Manoma, administracijos darbuotojų nuomoné sutapo su keleivių nuomone dèl to, kad jie nedirba traukinyje kaip traukini aptarnaujantys darbuotojai, todèl jiems yra lengviau vertinti kriterijų svarbą iš keleivio pozicijos. Dèl neesminių kriterijų visų vertintojų nuomonès išsiskyrè (2.4 ir 3.1a, 3.2a, 3.3a pav.). Panašios tik keleivių ir traukini aptarnaujančio personalo nuomonès dèl A1 ir traukini aptarnaujančio personalo ir administracijos darbuotojų nuomonès dèl A12 kriterijų.

Labai artimos yra traukini aptarnaujančio personalo ir administracijos darbuotojų nuomonès dèl B grupès kriterijų svarbumo (2.4 ir 3.2b, 3.3b pav.). Šiems vertintojams svarbūs B15, B19, B1 kriterijai. Ekspertai, kaip turintys patirti specialistai, supranta šių kriterijų svarbą keleivių vežimų kokybei. Panašios ekspertų nuomonès ir dèl neesminių dalykų - B8 ir B11 kriterijų.

Visiškai sutampa keleivių ir administracijos darbuotojų nuomonès dèl visų C grupès kriterijų svarbumo, labai panaši yra ir traukini aptarnaujančių darbuotojų nuomonè ( 2.4 ir $3.1 \mathrm{c}, 3.2 \mathrm{c}, 3.3 \mathrm{c}$ pav.).

Sutampa (2.4 ir 3.2d, 3.3d pav.) ekspertų nuomonè dèl D4 kriterijaus svarbumo. Kaip specialistai jie ivvertina šio kriterijaus svarbą eismo saugumui. Dèl D1 kriterijaus labai panašios yra keleivių ir administracijos darbuotojų nuomonės (2.4 ir $3.1 \mathrm{~d}, 3.3 \mathrm{~d}$ pav.). Nedaug skiriasi visų trijų grupių vertintojų nuomoné dėl neesminių (jų nuomone) kriterijų - D3, D8 ir D6 (2.4 ir 3.1d, 3.2d, 3.3d pav.).

Taigi, atlikus išsamią trijų kategorijų vertintojų analizę dèl KVGKK kriterijų svarbumo, matyti (2.4 pav. ir 3.7 lentelè), kad respondentams ir ekspertams svarbiausi yra A7, A2 ir A6, B1, B15 ir B13, C1, C5 ir C4, D4, D1 ir D7 kriterijai. 


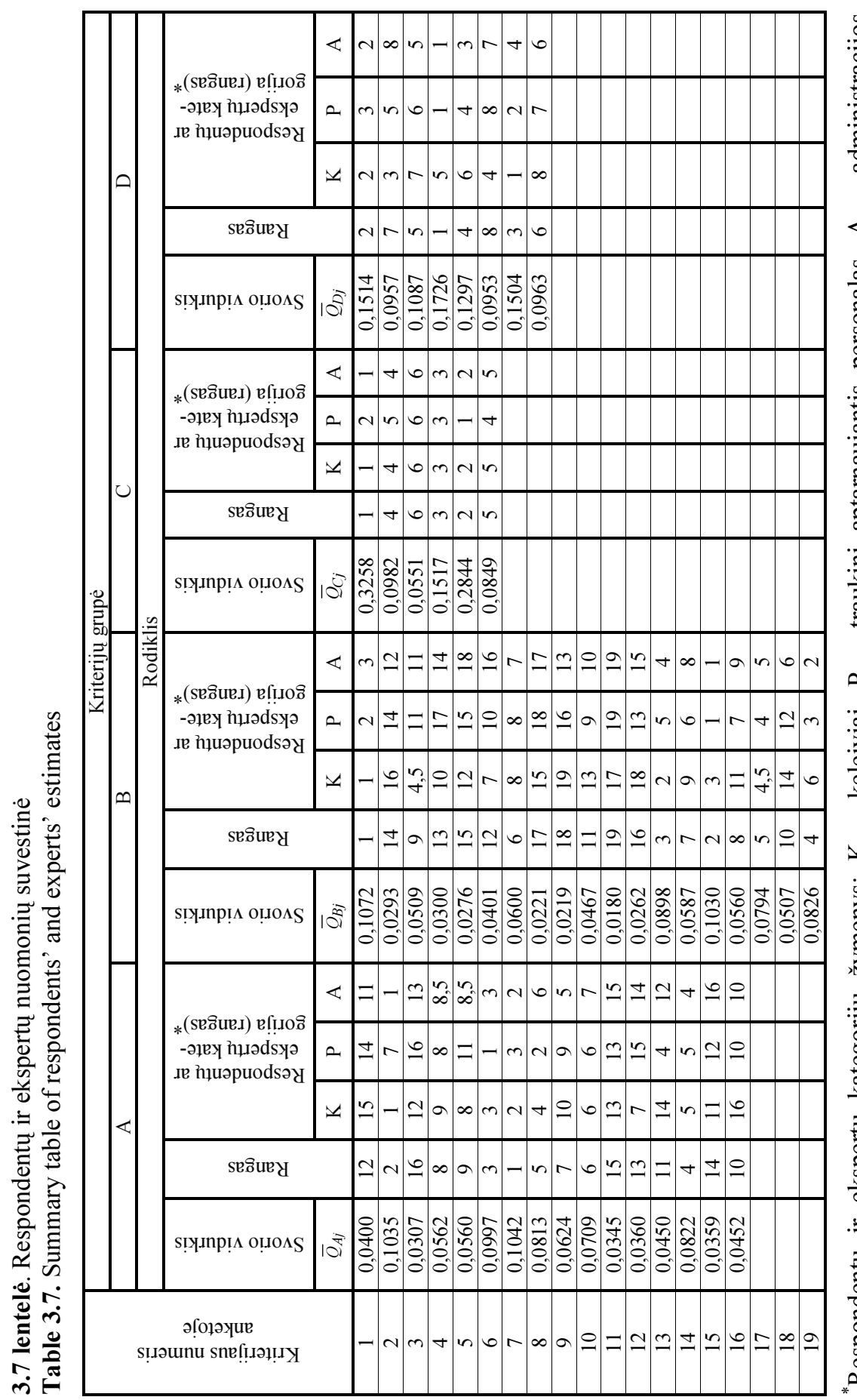


Turint atskirų kategorijų respondentų ir ekspertų TKVGK kriterijams suteiktus rangus (3.7 lentelè), galima nustatyti jų nuomonių panašumą pagal rangų skirtumų sumą. Kuo dviejų kategorijų respondentų ir ekspertų arba ekspertų ir ekspertų kriterijams suteiktų rangų skirtumų modulių suma yra mažesnè, tuo nuomonès yra vienodesnès. Rangų vidutiniai skirtumai skaičiuojami pagal formulę:

$$
\bar{R}_{1-2}=\frac{\sum_{j=1}^{m}\left|R_{1-2}\right|_{j}}{m},
$$

čia: $\left|R_{1-2}\right|_{j}$-tiriamos kriteriju grupès (A, B, C arba D) j-ajam kriterijui respondentų ir ekspertų arba ekspertų ir ekspertų suteiktų rangų skirtumo modulis (absoliutinè reikšmè); $m$-kriterijų skaičius kriteriju grupejje; indeksai prie $R 1$ ir 2 žymi pirmos ir antros kategorijos respondentus ir ekspertus, kurių kriterijams suteikti rangai lyginami tarpusavyje. Kai respondentų ir ekspertu arba ekspertu ir ekspertų suteiktų kriterijų grupès visų kriterijų rangai sutampa, tai $\bar{R}_{1-2}=0$, o nuomonès būna absoliučiai vienodos. Dydžiui $\bar{R}_{1-2}$ didèjant, nuomonių skirtumai taip pat didèja.

Artimesnès yra (respondentų) keleivių ir ekspertų (administracijos darbuotoju) nuomonès (3.8 lentelè).

3.8 lentelè. Respondentų ir ekspertų nuomonių (rangų) sutapimo atvejų skaičius Table 3.8. The number of matching estimates (ranks) provided by respondents and experts

\begin{tabular}{|c|c|c|c|}
\hline Kriterijų grupe & $\mathrm{K}=\mathrm{P}$ & $\mathrm{K}=\mathrm{A}$ & $\mathrm{P}=\mathrm{A}$ \\
\hline $\mathrm{A}$ & 3 & 4 & 2 \\
\hline $\mathrm{B}$ & 2 & 0 & 3 \\
\hline $\mathrm{C}$ & 2 & 6 & 2 \\
\hline $\mathrm{D}$ & 0 & 1 & 1 \\
\hline Iš viso & 7 & 11 & 8 \\
\hline
\end{tabular}

Apskaičiuotos $\bar{R}_{1-2}$ vertès pateiktos 3.9 lentelèje. 
3.9 lentelè. Respondentų ir ekspertų kriterijams suteiktų rangų skirtumai

Table 3.9. Differences in ranks assigned to the criteria by respondents and experts

\begin{tabular}{|c|c|c|c|c|c|c|c|c|c|c|c|c|}
\hline \multirow{4}{*}{$\begin{array}{c}\text { Kriterijaus } \\
\text { numeris } \\
\text { anketoje }\end{array}$} & \multicolumn{12}{|c|}{ Kriteriju grupè } \\
\hline & \multicolumn{3}{|c|}{ A } & \multicolumn{3}{|c|}{$\mathrm{B}$} & \multicolumn{3}{|c|}{$\mathrm{C}$} & \multicolumn{3}{|c|}{$\mathrm{D}$} \\
\hline & \multicolumn{12}{|c|}{ Atskiru kategorijų respondentu ir ekspertu lyginamosios poros } \\
\hline & $R_{K-P}$ & $R_{K-A}$ & $R_{P-A}$ & $R_{K-P}$ & $R_{K-A}$ & $R_{P-A}$ & $R_{K-P}$ & $R_{K-A}$ & $R_{P-A}$ & $R_{K-P}$ & $R_{K-A}$ & $R_{P-A}$ \\
\hline 1 & 1 & 4 & 3 & -1 & -2 & -1 & -1 & 0 & 1 & -1 & 0 & 1 \\
\hline 2 & -6 & 0 & 6 & 4 & 4 & 2 & -1 & 0 & 1 & -2 & -5 & -3 \\
\hline 3 & -4 & -1 & 3 & $-6,5$ & $-6,5$ & 0 & 0 & 0 & 0 & 1 & 2 & 1 \\
\hline 4 & 1 & 0,5 & $-0,5$ & -7 & -4 & 3 & 0 & 0 & 0 & 4 & 4 & 4 \\
\hline 5 & -3 & $-0,5$ & 2,5 & -3 & -6 & -3 & 1 & 0 & -1 & 2 & 3 & 1 \\
\hline 6 & 2 & 0 & -2 & -3 & -9 & -6 & 1 & 0 & -1 & -4 & -3 & 1 \\
\hline 7 & -1 & 0 & 1 & 0 & 1 & 1 & & & & -1 & -3 & -2 \\
\hline 8 & 2 & -2 & -4 & -3 & -2 & 1 & & & & 1 & 2 & 1 \\
\hline 9 & 1 & 5 & 4 & 3 & 6 & 3 & & & & & & \\
\hline 10 & 0 & -1 & -1 & 4 & 3 & -1 & & & & & & \\
\hline 11 & 0 & 2 & -2 & -2 & -2 & 0 & & & & & & \\
\hline 12 & -8 & -7 & 1 & 5 & 3 & -2 & & & & & & \\
\hline 13 & 10 & 2 & -8 & -3 & -2 & 1 & & & & & & \\
\hline 14 & 0 & 1 & 1 & 3 & 1 & -2 & & & & & & \\
\hline 15 & -1 & -5 & -4 & 2 & 2 & 0 & & & & & & \\
\hline 16 & 6 & 6 & 2 & 4 & 2 & -2 & & & & & & \\
\hline 17 & & & & 0,5 & $-0,5$ & -1 & & & & & & \\
\hline 18 & & & & 2 & 8 & 6 & & & & & & \\
\hline 19 & & & & 3 & 4 & 1 & & & & & & \\
\hline$\sum_{j=1}^{m}\left|R_{1-2}\right|_{j}$ & 46 & 37 & 43 & 59 & 68 & 36 & 4 & 0 & 4 & 16 & 22 & 10 \\
\hline $\bar{R}_{1-2}$ & 2,88 & 2,31 & 2,69 & 3,11 & 3,58 & 1,89 & 0,67 & 0 & 0,67 & 2 & 2,75 & 1,25 \\
\hline
\end{tabular}

Iš apskaičiuotų $\bar{R}_{1-2}$ verčiu matyti, kad vertinant A kriterijų grupès visus kriterijus vienodesnès (panašesnès) yra keleivių ir administracijos darbuotojų nuomonès $\left(\bar{R}_{K-A}=2,31\right)$. Vertinant visus B kriterijų grupès kriterijus vienodesnès yra traukini aptarnaujančio personalo ir administracijos darbuotojų nuomonès $\left(\bar{R}_{P-A}=1,89\right)$. Vertinant visus $\mathrm{C}$ kriteriju grupès kriterijus absoliučiai vienodos yra keleivių ir administracijos darbuotojų nuomonès $\left(\bar{R}_{K-A}=0\right)$. D kriterijų grupès visų kriterijų svarbą panašiau vertino traukinị aptarnaujantis personalas ir administracijos darbuotojai $\left(\bar{R}_{P-A}=1,25\right)$. 


\subsection{Respondentų ir ekspertų, nustačiusių kelionès traukiniu kokybės kriteriju grupių svarbą, apklausos rezultatai ir nuomonių lyginamoji analizè}

Suformulavus ir susisteminus TKVGK rodančius kriterijus ir nustačius jų svorius, buvo nustatyta šių A, B, C ir D kriterijų grupių svarba (pirmumas) (Maskeliūnaite, Sivilevičius 2012). Traukinio Vilnius-Maskva respondentams (21 keleiviui) ir išmanantiems traukinio elementų, geležinkelio kelio techninę būklę, kelionės traukiniu proceso organizavimą ir technologija, priemones vežimo saugumui užtikrinti, vežimo kokybès reikalavimus, 29 ekspertams (20 traukini Vilnius-Maskva aptarnaujantiems darbuotojams ir 9 AB „Lietuvos geležinkeliai“ administracijos darbuotojams) buvo iteiktos apklausos anketos (E priedas), kuriose prašoma pateikti KTK A, B, C ir D kriterijų grupių (2.4 pav.) svarbos (pirmumo) iverčius (rangus). KTK A, B, C ir D kriteriju grupiu pirmumo ivertinimas $R_{i j}$ (rangai) respondentų ir ekspertų požiūriu pateikta $\mathrm{F}$ priede.

Visų respondentų ir ekspertų TKVGK A, B, C ir D kriterijų grupių vidutinių rangu $\bar{R}_{g}$ apskaičiuotuju verčių stulpelinès diagramos pateiktos 3.5 paveiksle.

Bendrieji 21 keleivio, 20 traukini aptarnaujančio personalo ir $9 \mathrm{AB}$ „Lietuvos geležinkeliai“ administracijos darbuotojų užpildytų apklausos anketų duomenys pateikti 3.10 lentelèje. Taikant anksčiau pateiktą metodiką nustatytas kiekvienos respondentų ir ekspertų kategorijos atskirai, taip pat bendrasis visų respondentų ir ekspertų (50 vertintojų) nuomonių suderinamumas (3.10 lentelè).

Respondentų ir ekspertų kiekvienos kriterijų grupès svarbumo rodiklis $Z_{g}$ apskaičiuojamas pagal formulę:

$$
Z_{g}=\frac{(g+1)-\bar{R}_{g}}{\sum_{g=1}^{M} \bar{R}_{g}},
$$

čia: $M$ - kriterijų grupių skaičius $(g=1,2, \ldots, M), \quad M=4 ; \bar{R}_{g}-g$-osios kriterijų grupès vidutinis rangas, apskaičiuotas pagal (3.12) formulę.

Apskaičiuotieji KTK A, B, C, D kriterijų grupių keleivių požiūriu vidutiniai rangai $\bar{R}_{g}$ rodo, kad rodiklis (kriteriju grupè) $\mathrm{C}$ svarbesnis už $\mathrm{B}, \mathrm{D}$ ir $\mathrm{A}$, t. y. gaunama tokia hierarchija: C > B > D > A. Apskaičiuotieji KTK A, B, C, D kriteriju grupių traukini aptarnaujančio personalo požiūriu vidutiniai rangai $\bar{R}_{g}$ rodo, kad rodiklis $\mathrm{D}$ svarbesnis už $\mathrm{A}, \mathrm{C}$ ir $\mathrm{B}, \mathrm{t}$. y. gaunama tokia hierarchija: $\mathrm{D}>\mathrm{A}>\mathrm{C}>\mathrm{B}$, o $\mathrm{AB}$,Lietuvos geležinkeliai“ administracijos darbuotojų požiūriu: $\mathrm{C}>\mathrm{D}>\mathrm{B}>\mathrm{A}$. Kiek kriteriju grupès svarbesnès viena už kitą, apskaičiuo- 
tieji vidutiniai rangai $\bar{R}_{g}$ nerodo. Artimesnès yra keleivių ir administracijos darbuotojų nuomonès (3.11 lentelè), kurios buvo vienodos dèl kelionès traukiniu kokybès kriterijų grupių A ir C pirmumo (svarbos).

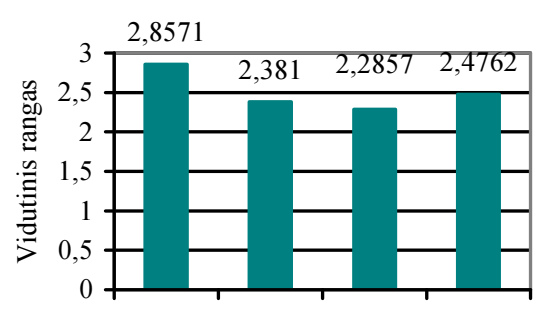

A B

Kokybès kriterijų grupès

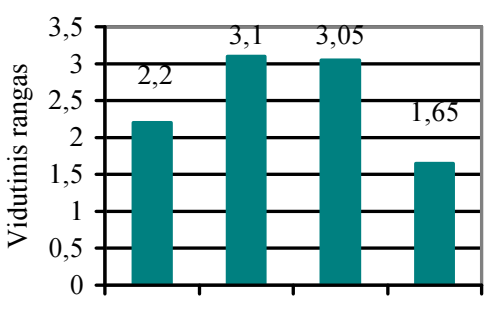

A $\quad$ B $\quad$ C $\quad$ D

Kokybès kriteriju grupès

a)

b)

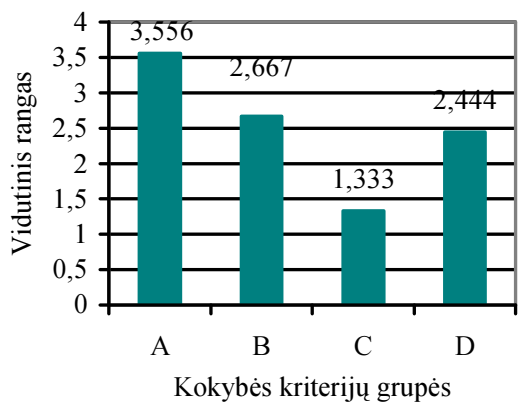

c)

3.5 pav. Kelionès traukiniu kokybès A, B, C, D kriterijų grupių vidutinių rangu stulpeliné diagrama: a) keleivių nuomone $n=21, W=0,038, W_{\min }=0,180, \chi^{2}=2,37$, $\chi_{\alpha, v}^{2}=11,34 ;$ b) traukini aptarnaujančio personalo nuomone $n=20, W=0,295$, $W_{\min }=0,189, \chi^{2}=17,70, \chi_{\alpha, v}^{2}=11,34 ;$ c) AB ,Lietuvos geležinkeliai“ administracijos darbuotojų nuomone $n=9, W=0,501, W_{\min }=0,420, \chi^{2}=13,53, \chi_{\alpha, v}^{2}=11,34$

Fig.3.5. The bar diagram of the average ranks given to the criteria groups A, B, C, D describing railway trip quality: a) by passengers $(n=21), W=0,038, W_{\min }=0,180$, $\chi^{2}=2,37, \chi_{\alpha, v}^{2}=11,34$; b) by the service staff of the train $n=20, W=0,295$, $\left.W_{\min }=0,189, \chi^{2}=17,70, \chi_{\alpha, v}^{2}=11,34 ; \mathrm{c}\right)$ by the administration staff of the company "Lietuvos geležinkeliai" $n=9, W=0,501, W_{\min }=0,420, \chi^{2}=13,53, \chi_{\alpha, v}^{2}=11,34$ 
Respondentų ir ekspertų konkordancijos koeficiento $W$, kritinės reikšmės $\chi_{\alpha, v}^{2}$ (paimtos iš skirstinio lentelès su atitinkamu laisvès laipsniu ir reikšmingumo lygmeniu $\alpha=0,010$ ) ir mažiausio konkordancijos koeficiento $W_{\min }$ reikšmès pateiktos 3.10 lentelèje.

3.10 lentelè. Ekspertų $(\mathrm{P}, \mathrm{A})$ ir respondentu $(\mathrm{K})$ kategorijų konkordancijos koeficiento $W$, kritinès reikšmès $\chi_{\alpha, v}^{2}$ ir mažiausio konkordancijos koeficiento $W_{\min }$ reikšmès

Table 3.10. The concordance coefficient $W$, critical value $\chi_{\alpha, v}^{2}$ and the smallest concordance coefficient $W_{\min }$ obtained for the estimates provided by experts (P, A) and respondents $(\mathrm{K})$

\begin{tabular}{|c|c|c|c|c|}
\hline $\begin{array}{c}\text { Respondentuc } \\
\text { ar ekspertu } \\
\text { kategorija }^{*}\end{array}$ & \multicolumn{4}{|c|}{ Reikšmé } \\
\cline { 2 - 5 } & $W$ & $W_{\min }$ & $\chi^{2}$ & $\chi_{\alpha, v}^{2}$ \\
\hline $\mathrm{K}$ & 0,038 & 0,180 & 2,37 & 11,34 \\
\hline $\mathrm{P}$ & 0,295 & 0,189 & 17,70 & 11,34 \\
\hline $\mathrm{A}$ & 0,501 & 0,420 & 13,53 & 11,34 \\
\hline $\mathrm{B}(\mathrm{K}, \mathrm{P}, \mathrm{A})$ & 0,047 & 0,0756 & 6,984 & 11,34 \\
\hline
\end{tabular}

*Respondentų ir ekspertų kategorijų žymenys: $\mathrm{K}$ - keleiviai, $\mathrm{P}$ - traukinį aptarnaujantis personalas, A - administracijos darbuotojai, B - bendras respondentu (keleiviu) ir ekspertų (traukini aptarnaujančio personalo ir administracijos darbuotoju)

Matyti, kad respondentų nuomonès dèl KTK A, B, C, D kriterijų grupių svarbos (pirmumo) yra prieštaringos, o ekspertų nuomonès yra suderintos. Bendroji visų respondentų ir ekspertų nuomonè yra taip pat prieštaringa. Galima daryti prielaidą, kad keleivių poreikiai ir interesai yra labai skirtingi: pavyzdžiui, vieniems yra svarbi kelionès kaina ir ne taip svarbu komforto lygis, kitiems - atvirkščiai.

3.11 lentelè. Respondentų ir ekspertų nuomonių (rangų) sutapimo atvejų skaičius

Table 3.11. The number of matching estimates (ranks) provided by respondents and experts

\begin{tabular}{|c|c|c|c|}
\hline Kriteriju grupe & $\mathrm{K}=\mathrm{P}$ & $\mathrm{K}=\mathrm{A}$ & $\mathrm{P}=\mathrm{A}$ \\
\hline $\mathrm{A}$ & 0 & 1 & 0 \\
\hline $\mathrm{B}$ & 0 & 0 & 0 \\
\hline $\mathrm{C}$ & 0 & 1 & 0 \\
\hline $\mathrm{D}$ & 0 & 0 & 0 \\
\hline Iš viso & 0 & 2 & 0 \\
\hline
\end{tabular}

"Respondentų ir ekspertų kategorijų žymenys: $\mathrm{K}$ - keleiviai, $\mathrm{P}$ - traukini aptarnaujantis personalas, $\mathrm{A}$ - administracijos darbuotojai 
Visų trijų tyrime dalyvavusių kategorijų $(\mathrm{K}, \mathrm{P}, \mathrm{A})$ respondentų ir ekspertų nuomonių apie kriterijų grupès A svarbą rodo vidutinis svorio koeficientas $Z \square_{A}$ (kai respondentų ir ekspertų skaičius kiekvienoje kategorijoje yra vienodas), kuris apskaičiuojamas pagal formulę:

$$
\bar{Z}_{A}=\frac{\sum_{z=1}^{N} Z_{A z}}{3}=\frac{Z_{A K}+Z_{A P}+Z_{A A}}{3},
$$

čia: $Z_{A z}$ - A kriterijų (anketų) grupei $z$-sios kategorijos respondento (eksperto) suteiktas svorio koeficientas; $N$ - respondentu (ekspertu) kategorijų skaičius, $(z=1, \ldots, N),(N=3) ; Z_{A K}, Z_{A P}, Z_{A A}-$ keleivių, traukini aptarnaujančio personalo ir administracijos darbuotojų suteiktas A kriterijų grupei svoris.

Kitu (B, C, D) kriteriju grupių vidutiniai svorio koeficientai $\bar{Z}_{B}, \bar{Z}_{C}, \bar{Z}_{D}$ buvo apskaičiuoti pagal analogiškas formules (3.12 lentelè):

$$
\begin{aligned}
& \bar{Z}_{B}=\frac{\sum_{z=1}^{N} Z_{B z}}{3}=\frac{Z_{B K}+Z_{B P}+Z_{B A}}{3} ; \\
& \bar{Z}_{C}=\frac{\sum_{z=1}^{N} Z_{C z}}{3}=\frac{Z_{C K}+Z_{C P}+Z_{C A}}{3} ; \\
& \bar{Z}_{D}=\frac{\sum_{z=1}^{N} Z_{D z}}{3}=\frac{Z_{D K}+Z_{D P}+Z_{D A}}{3} .
\end{aligned}
$$

Visų trijų tyrime dalyvavusių kategorijų $(\mathrm{K}, \mathrm{P}, \mathrm{A})$ respondentų ir ekspertų nuomoniu apie A grupès kriterijų svarbą rodo vidutinis svorio koeficientas $\bar{Z}_{A}^{*}$ (kai respondentų ir ekspertų skaičius kiekvienoje kategorijoje yra nevienodas), kuris apskaičiuojamas pagal formulę:

$$
\bar{Z}_{A}^{*}=\frac{\sum_{i=1}^{n} Z_{i} \cdot n_{z}}{\sum_{z=1}^{N} n_{z}}=\frac{Z_{A K} \cdot n_{K}+Z_{A P} \cdot n_{P}+Z_{A A} \cdot n_{A}}{n_{K}+n_{P}+n_{A}},
$$

čia: $Z_{A K}, Z_{A P}, Z_{A A}-\mathrm{A}$ kriteriju (anketu) grupei $\mathrm{K}, \mathrm{P}, \mathrm{A}$ kategorijos respondentų (ekspertu) suteiktas svorio koeficientas; $n_{K}, n_{P}, n_{A}-$ respondentų $(\mathrm{K})$ ar ekspertu $(\mathrm{P}, \mathrm{A})$ skaičius.

Tyrime dalyvavusių respondentų ir ekspertų skaičius yra nevienodas, todèl taikoma (3.25) formulè. Šią formulę taikyti tikslinga ir dèl to, kad respondentų yra daugiausia - 21 keleivis. Keleivių nuomonè yra prioritetinè. 
3.12 lentelè. Kelionès traukiniu kokybės kriterijų grupiu $A, B, C$ ir $D$ keleivių $(K)$, traukini aptarnaujančio personalo $(\mathrm{P})$ ir $\mathrm{AB}$,,Lietuvos geležinkeliai“ administracijos darbuotoju (A) ivertinti svarbumas (svoris) ir prioritetas

Table 3.12. Significance (weight) and preference order (rank) of groups of criteria A, B, $\mathrm{C}$ and $\mathrm{D}$, describing the railroad trip quality, determined by passengers $(\mathrm{K})$, service staff of the train (P) and administration staff (A) of the company "Lietuvos geležinkeliai"

\begin{tabular}{|c|c|c|c|c|c|}
\hline \multirow{2}{*}{ Svoriai $Z_{g z}, \bar{Z}_{g}, \bar{Z}_{g}^{*}$} & \multicolumn{4}{|c|}{ Kokybės kriteriju grupės žymuo } & \multirow[t]{2}{*}{ Suma } \\
\hline & A & $\mathrm{B}$ & $\mathrm{C}$ & $\mathrm{D}$ & \\
\hline \multicolumn{6}{|c|}{ Keleiviai $(n=21)$} \\
\hline$Z_{g K}$ & 0,2143 & 0,2619 & 0,2714 & 0,2524 & 1,000 \\
\hline Prioritetas & \begin{tabular}{|l|}
4 \\
\end{tabular} & 2 & 1 & 3 & - \\
\hline \multicolumn{6}{|c|}{ Traukini aptarnaujantis personalas $(n=20)$} \\
\hline$Z_{g P}$ & 0,2800 & 0,1900 & 0,1950 & 0,3350 & 1,000 \\
\hline Prioritetas & 2 & 4 & 3 & 1 & - \\
\hline \multicolumn{6}{|c|}{$\mathrm{AB}$, ,Lietuvos geležinkeliai“ administracijos darbuotojai $(n=9)$} \\
\hline$Z_{g A}$ & 0,1444 & 0,2333 & 0,3667 & 0,2556 & 1,000 \\
\hline Prioritetas & 4 & 3 & 1 & 2 & - \\
\hline $\begin{array}{c}\text { Visų ekspertų ir respondentų }(n=50) \text { nuomonių } \\
\text { vidurkis } \bar{Z}_{g}\end{array}$ & 0,2129 & 0,2284 & 0,2777 & 0,2810 & 1,000 \\
\hline $\begin{array}{l}\text { Visų ekspertų ir respondentų }(\mathrm{n}=50) \text { nuomonių } \\
\text { vidurkis, ivertinus jų skaičių kategorijose } \bar{Z}_{g}^{*}\end{array}$ & 0,2280 & 0,2280 & 0,2580 & 0,2860 & 1,000 \\
\hline
\end{tabular}

Kategorijų (K, P, A) respondentų ir ekspertų nuomonių apie B, C ir D kriterijų grupių svarbą vidutinis svorio koeficientas $\bar{Z}_{g}^{*}$ apskaičiuojamas pagal formules:

$$
\begin{aligned}
& \bar{Z}_{B}^{*}=\frac{\sum_{i=1}^{n} Z_{i} \cdot n_{z}}{\sum_{z=1}^{N} n_{z}}=\frac{Z_{B K} \cdot n_{K}+Z_{B P} \cdot n_{P}+Z_{B A} \cdot n_{A}}{n_{K}+n_{P}+n_{A}} ; \\
& \bar{Z}_{C}^{*}=\frac{\sum_{i=1}^{n} Z_{i} \cdot n_{z}}{\sum_{z=1}^{N} n_{z}}=\frac{Z_{C K} \cdot n_{K}+Z_{C P} \cdot n_{P}+Z_{C A} \cdot n_{A}}{n_{K}+n_{P}+n_{A}} ; \\
& \bar{Z}_{D}^{*}=\frac{\sum_{i=1}^{n} Z_{i} \cdot n_{z}}{\sum_{z=1}^{N} n_{z}}=\frac{Z_{D K} \cdot n_{K}+Z_{D P} \cdot n_{P}+Z_{D A} \cdot n_{A}}{n_{K}+n_{P}+n_{A}} .
\end{aligned}
$$


KTK kriterijų grupių A, B, C ir D keleivių (K), traukini aptarnaujančio personalo $(\mathrm{P})$ ir $\mathrm{AB}$ „Lietuvos geležinkeliai“ administracijos darbuotojų (A) nuomone svarbumo (svorio) rodiklio $Z_{g z}$ ir prioritetų skaičiavimo rezultatai pateikti 3.12 lenteleje, o svarbumo (svorio) rodiklio $Z_{g z}$ ir vidutinio svorio koeficiento $\bar{Z}_{g}, \bar{Z}_{g}^{*}$ laužtès pavaizduotos 3.6 paveiksle.

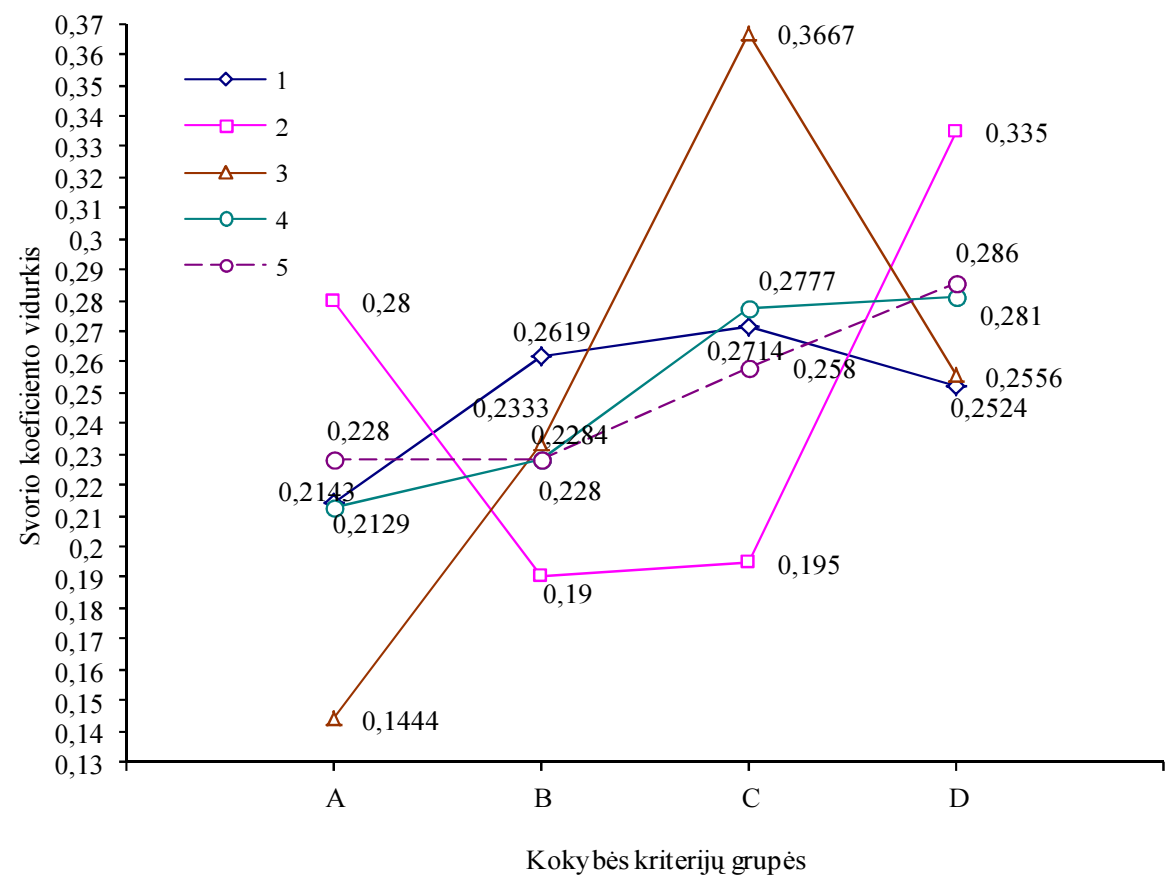

3.6 pav. Kelionès traukiniu kokybès kriterijų A, B, C ir D grupių pirmumo (svorio) laužtès: 1 - keleivių $(\mathrm{K}) ; 2$ - traukini aptarnaujančio personalo $(\mathrm{P}) ; 3-\mathrm{AB}$,Lietuvos geležinkeliai“ administracijos darbuotojų (A); 4 - visų ekspertų ir respondentų $(n=50)$ nuomonių vidurkio $\bar{Z}_{g} ; 5$ - visų ekspertų ir respondentų nuomonių vidurkio, įvertinus jų skaičiu kategorijose $\bar{Z}_{g}^{*}$

Fig. 3.6. The broken lines showing the weight of the groups of railway trip quality criteria A, B, C and D, given by 1) passengers (K);2) the train service staff (P); 3 ) the administration staff of "Lietuvos geležinkeliai" (A); 4) all experts and residents ( $n=50$ ), based on their mean estimate $\left.\bar{Z}_{g} ; 5\right)$ all experts and residents $(n=50)$, based on the mean estimate $\bar{Z}_{g}^{*}$ of all experts and residents, taking into account their number in a category 
Keleiviai mano, kad kelionès tarptautiniu traukiniu kokybės $\mathrm{C}$ kriterijų grupé yra svarbiausia, nes $Z_{C K}=0,2714$. Šiek tiek mažiau svarbi yra B kriteriju grupé, nes $Z_{B K}=0,2619$ ir mažiausiai svarbi A kriterijų grupé, kadangi $Z_{A K}=0,2143$. Traukini aptarnaujančiam personalui svarbiausia yra A kriterijų grupè $Z_{A P}=0,280$ ir D kriterijų grupe $Z_{D P}=0,335$. AB „Lietuvos geležinkeliai““ administracijos darbuotojai mano, kad svarbiausia yra $C$ kriterijų grupé, nes $Z_{C A}=0,3667$ ir mažiausiai svarbi A kriteriju grupe, nes $Z_{A A}=0,1444$. Svorio koeficientų reikšmės rodo, kad atskirų kategorijų respondentų ir ekspertų nuomonès dažnai skiriasi arba yra prieštaringos vienos kitoms. Skirtingomis formulèmis apskaičiuotos vidutinès kriterijų grupių svorio koeficientų vertès rodo, kad D kriterijų grupé svarbesnè už C, C kriterijų grupé svarbesnè už B, o B kriterijų grupe svarbesnè už A. Remiantis šiais duomenimis, galima teigti, kad visų suinteresuotų kategorijų respondentams ir ekspertams kelio ir riedmenų parametrai (A kriterijų grupè) yra mažiausiai svarbūs, o svarbiausi saugaus eismo parametrai (D kriterijų grupè).

\subsection{Trečiojo skyriaus išvados}

1. Statistiškai apdorojus A, B, C ir D kriterijų grupių, respondentų ir ekspertų anketų duomenis, nustatyti keleivių vežimų geležinkeliais svarbiausi kriterijai, jų svoriai ir atskirų šių kriterijų grupių svarba (pirmumas), pagal kurių vertes parodyta jų svarba ir įtaka, leidžianti pagerinti kelionių traukiniais kokybę.

2. Hierarchijų analizès procesų (AHP) metodas yra ypatingas tuo, kad reikalauja aukšto loginio mąstymo. Būtina aukšta specialistų (ekspertų) kvalifikacija, nes nuo jos priklauso nuomonių suderinamumas. Vieno labai kompetentingo eksperto nuomonè yra svarbesnè už kelių, keliolikos ar keliasdešimt nepatyrusių (nesugebančių logiškai mąstyti) specialistų nuomonę.

3. Taikyti ekspertinių vertinimų ir ypač AHP metodą tyrimui traukinyje buvo sunku. Keleiviai buvo neiniciatyvūs respondentai. Anketų pildymui didelę itaką turejjo traukini aptarnaujančio personalo motyvacija tyrimui. Keleivių nuomonès dèl visų grupių kriterijų svarbos yra gerai suderintos. Dẻl kelionės traukiniu kokybès A, B, C, D kriterijų grupių svarbos keleivių nuomonès yra nesuderintos. Keleiviu poreikiai yra skirtingi: vieniems svarbesnè kelionès kaina, o paslaugu asortimentas ir kokybė yra antraeiliai dalykai, kitiems - nesvarbi kelionès kaina, tačiau jie pageidauja kuo įvairesnių kokybiškų paslaugų, patogumo.

4. Traukini aptarnaujančio personalo nuomonès dèl visų grupių kriterijų svarbos ir kriterijų grupių pirmumo gerai suderintos. Juos galima priskirti prie kvalifikuotų vertintojų, nors jiems nepavyko visiškai atsiriboti nuo savo darbo itakos ir vertinti kriterijus keleivio požiūriu. 
5. Administracijos darbuotojų nuomonès dèl kriterijų, susietų su kelionės traukiniu saugumu, yra nesuderintos. Galbūt ekspertams, vertinant šiuos kriterijus, pritrūko kruopštumo, loginio mąstymo ar kompetencijos. Dèl kelionès traukiniu kokybès A, B, C, D kriterijų grupių svarbos jų nuomonès yra suderintos.

6. Artimesnès yra keleivių ir administracijos darbuotojų nuomonès. Jie nedirba traukinyje, kaip traukini aptarnaujantys darbuotojai, todèl jiems yra lengviau vertinti kriterijų svarbą iš keleivio pozicijos.

7. Dèl traukini aptarnaujančio personalo (traukinio viršininkų, vagonų palydovų) ir pačių keleiviu pasyvumo, abejingumo tyrimui (mieliau skaitė knyga arba lankèsi restorano vagone), nepavyko apklausos atlikti kitų maršrutų traukiniuose, padidinti respondentų skaičiaus. 



\section{4}

\section{Modeliu taikymas vertinant keleiviu vežimo geležinkeliais kokybę}

Pagal sudarytas KKVR, ivertinančio kiekvieno A, B, C ir D grupių kriterijų itaka, dèmenų skaičiavimo formules apskaičiuojama kiekvieno dèmens reikšmè su realiais duomenimis, paimtais iš norminių dokumentų, techninès dokumentacijos, apklausų, matavimų ir kitokių patikimų šaltinių. Testai (bandymai) atlikti tarptautinio susisiekimo traukiniui Vilnius-Maskva (Sivilevičius et al. 2012).

\subsection{Kriterijų, susietu su traukinio elementais ir geležinkelio kelio technine būkle, modelio praktinio pritaikymo vertinimas}

1. Geležinkelio bėgių (kelio) lygumas. LG geometriniams kelio parametrams matuoti naudoja $2009 \mathrm{~m}$. bendrovès „Plasser\&Theurer“ (Austrija) pagamintą savaeigi kelio kontrolès vagoną EM-140 (4.1 pav.). Kelmačiu matuojami ir užrašomi elektroninejje laikmenoje šie bėgių kelio geometriniai parametrai:

- vèžès plotis;

- bėgių padètis vienas kito atžvilgiu pagal bėgių galvutès lygi;

- abiejų bėgiu įdubos; 
- bègiu padètis plane;

- kreiviu spinduliai;

- perkrypos;

- leidžiamasis greitis kreivejje;

- geležinkelio kelio išorinio bėgio pakylos nuolydis;

- išilginis kelio nuolydis.

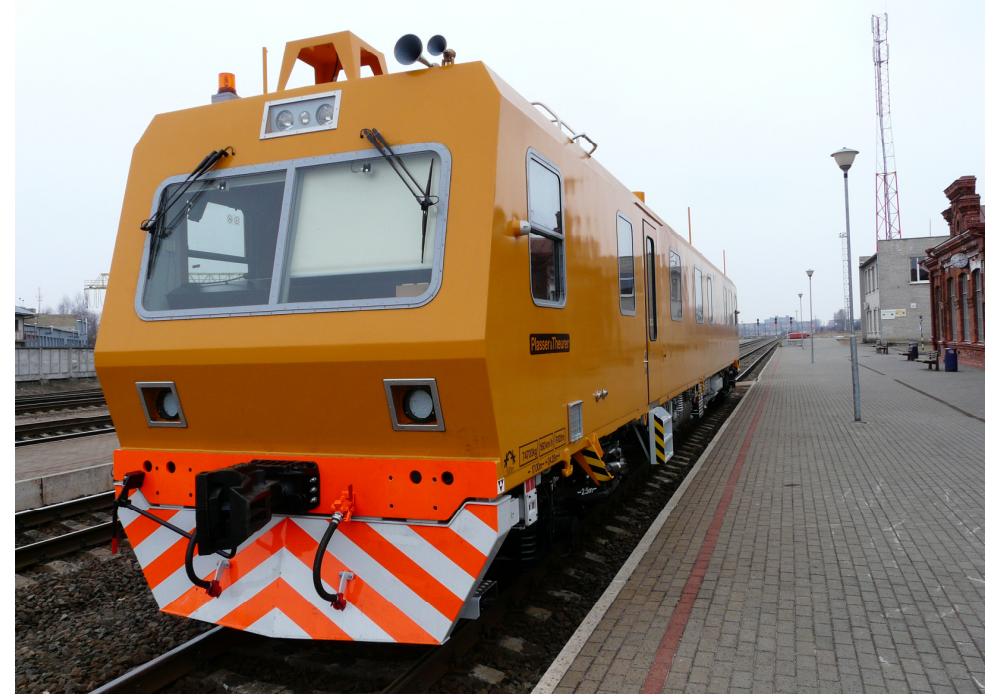

4.1 pav. Savaeigis vagonas EM-140

Fig. 4.1. Self-propelled car EM-140

Šaltinis: AB ,Lietuvos geležinkeliai“ "archyvas

Kelmačiu užrašomi papildomi parametrai ir atžymos:

- esamas mašinos greitis (užrašo duomenis judèdamas sava eiga iki $140 \mathrm{~km} / \mathrm{h}$. Gali atlikti matavimus ir važiuodamas sąstato sudètyje, jeigu reikalingi greičiai iki $160 \mathrm{~km} / \mathrm{h}$ );

- kilometras;

- piketas;

- infrastruktūros objektų atžymos (iešmas, tiltas, tunelis, šviesoforas, pervaža).

Visi matavimo irenginiai (4.2 pav.) yra sumontuoti ant matavimo rèmo, kuris tvirtinamas prie kelmačio vežimèlio ašidežiu. Tokia konstrukcija užtikrina, kad visi matavimo i̇renginiai visada yra lygiagrečiai bejgiams. Visi geometriniai kelio parametrai yra gaunami iš tiksliai išmatuotos kelio erdvinès kreivès (4.3 pav.). 


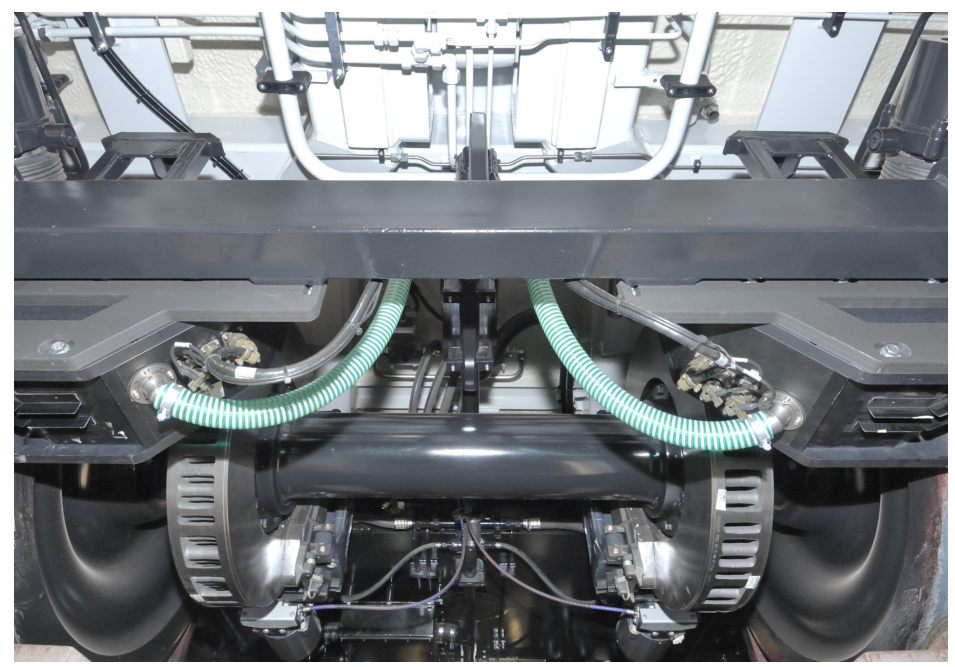

4.2 pav. Matavimo rèmas su inercinio matavimo bloku ir optinė kelio matavimo sistema (OGMS)

Fig. 4.2. A measuring frame with the inertial measurement unit and the optical track measurement system (OGMS)

Šaltinis: AB ,Lietuvos geležinkeliai“ archyvas

Piketų ir kilometrų ribos bėgių kelio geometrinių parametrų būklès nuokrypių grafike žymimos automatiškai. Kelmatis bėgių kelio geometrinius parametrus matuoja ir duomenis saugo skaitmeninejje laikmenoje. Kelmačio darbuotojai grafinius kelio geometrinių parametru duomenis spausdina popieriaus lape ir stebi juos kompiuterio ekrane. Bègių kelio geometrinių parametrų nuokrypių ataskaita sudaroma ir spausdinama iš karto, atliekant kelio patikra.

Svarbiausių Lietuvos Respublikos geležinkelio kelio kokybès indekso (KKI), išmatuoto kelmačiu EM-140 (kas kilometras) 2012 m. sausio mènesi, kitimas ir jo atitiktis normų reikalavimams pateiktas 4.4 paveiksle. Kitų (vasaris-gegužè) mènesių matavimai pateikti G priede. Kelmačiu EM-140 2012 m. išmatuotų šių KKI reikšmiu pasiskirstymas (dinamika) pateikti H priede. Pagrindinių I ir II VilniusKena kelių procentinis kiekis verčių, atitinkančių KKI sausio-gegužès mènesiais, pavaizduotas 4.5 paveiksle. Kitų kelių procentinis kiekis verčių, atitinkančių KKI sausio-gegužès mėnesiais, pateiktas I priede. Šie duomenys rodo Lietuvos Respublikos pagrindinių geležinkelio kelių faktinę kokybę pagal KKI. Matyti, kad aiškios kelio kokybès kitimo tendencijos nèra. Jeigu nebūtų atliekami remonto darbai, tai dèl aplinkos oro temperatūros žiemą ir vasara, pasikartojančių važiuojančių traukinių apkrovų KKI turètų tendenciją blogèti. 


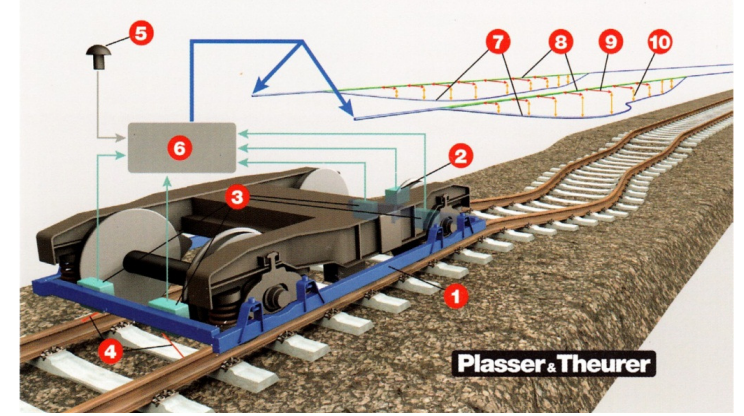

4.3 pav. Geometrinių kelio parametrų matavimas kelmačiu: 1 - matavimo rèmas su fiksuota lygiagrečia bėgiams padėtimi; 2 - inercinè matavimo sistema; 3 - optinè geometrinių parametrų matavimo sistema; 4 - lazerio spindulys; 5 - navigacijos sistemos antena (GPS); 6 - navigacijos kompiuteris; 7 - abiejų bėgių erdvės kreivè, gauta atlikus matavimus išilgai kelio ir suderinta su GPS duomenimis; 8 - projektinis kelio profilis; 9 - kelio nuokrypiai plane, gauti iš erdvinès kreivès; 10 - vertikalūs kelio nuokrypiai, gauti iš erdvinès kreivès

Fig. 4.3. Measurement of the track parameters by the track geometry car: 1 - measuring frame with fixed vertical distance to the rail surfaces; 2 - inertial measuring unit;

3 - sensors of the track gauge measurement; 4 - laser beams to scan the track gauge; 5 - GPS data acquisition; 6 - navigation computer; 7 - space curves of both rails derived from the measurements along the track, synchronised with GPS data; 8 - track design line; 9 - alignment defects, calculated from the space curve; 10 - longitudinal profile defects, calculated from the space curve

Šaltinis: Track recording cars, Plasser \&Theurer - the No.1 in measurig technology 2011

Apskaičiuojamas idealus, blogiausias ir realus kokybès lygis I pagrindinio kelio Vilnius-Kena pagal sausio mènesio KKI. Idealus ir blogiausias kelio kokybės lygis skaičiuojamas pagal 2.3 formulę (vienam kilometrui), nes geros kokybès kelyje, esant bent vienam blogos kokybès ruožui, tam keliui reikès atlikti remontą.

Skaičiuojamas geriausias atvejis (šiam keliui), kai $K K I_{f}=14,95$ (J priedas), o $K K I_{r i b}=45$ :

$$
x_{A 1}=1-\frac{K K I_{f}^{2}}{K K I_{r i b}^{2}}=1-\frac{14,95^{2}}{45^{2}}=0,89 .
$$

Gaunama, $\operatorname{kad} x_{A 1}=0,89$. Kai $K K I_{f}=0$, gaunama geriausia su šiuo faktiniu KKI kelio kokybè $x_{A 1}=1$.

Skaičiuojamas blogiausias atvejis, kai $K K I_{f}=64,04$, o $K K I_{r i b}=45$ :

$$
x_{A 1}=1-\frac{K K I_{f}^{2}}{K K I_{r i b}^{2}}=1-\frac{64,04^{2}}{45^{2}}=-1,025 \text {. }
$$




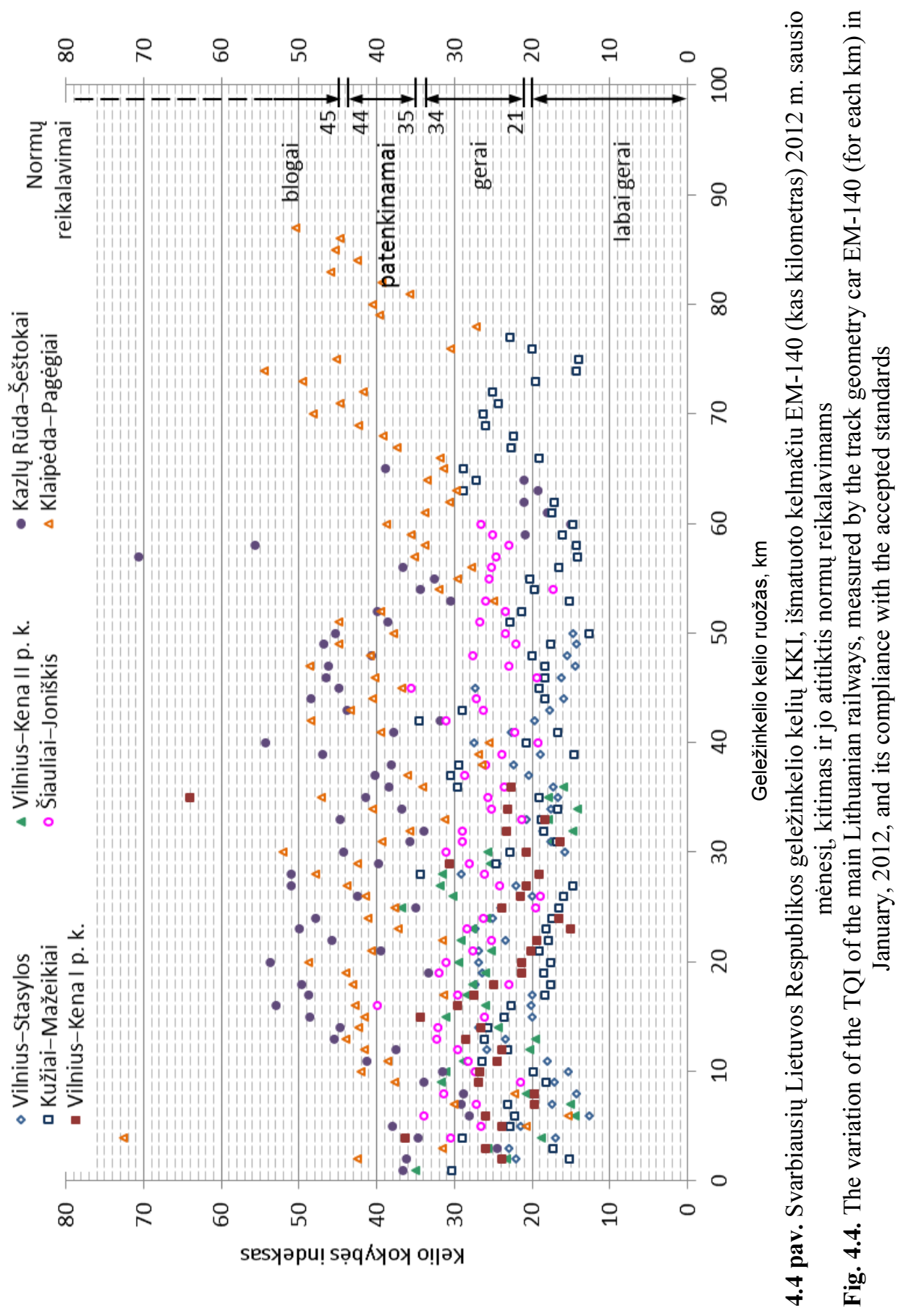


Gaunama neigiama reikšmè, todèl priimama, $\operatorname{kad} x_{A 1}=0$.

Reali kelio kokybe skaičiuojama pagal 2.4 (visam keliui) formulę. Kai

$$
\frac{\sum_{s=1}^{N_{k m}}\left(1-\frac{K K I_{f}^{2}}{K K I_{r i b}^{2}}\right)_{s}}{N_{k m}}=\frac{23,244}{36}, \text { o } x_{A 1}=0,646 \text {. }
$$

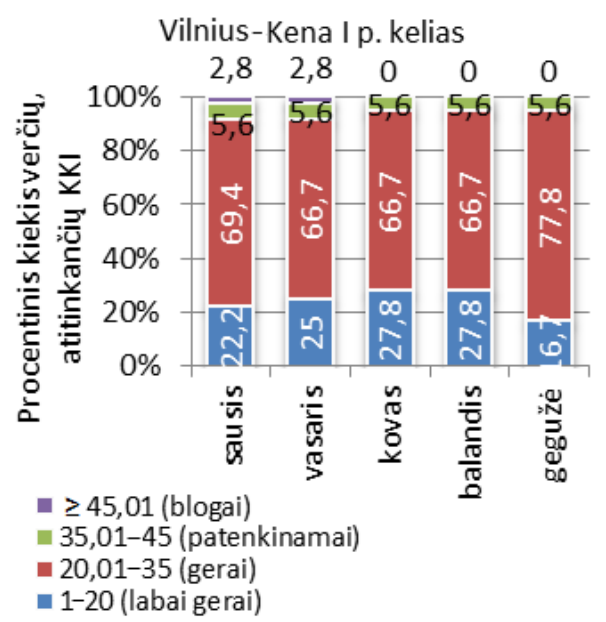

Vilnius-Kena I p. kelias

Vilnius-Kena II p. kelias

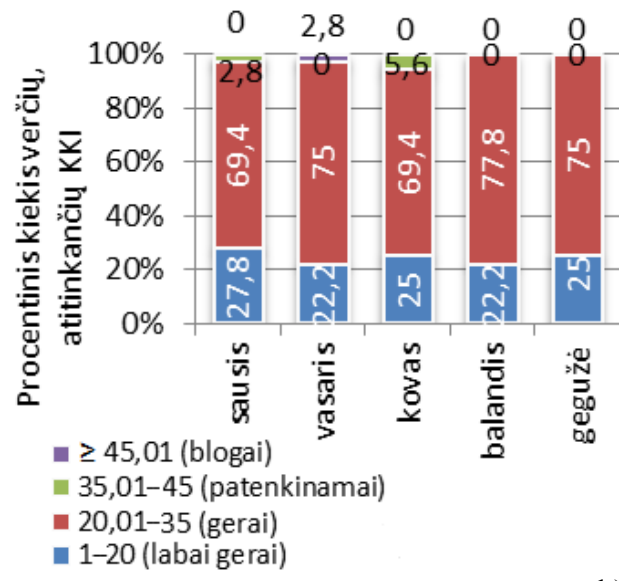

b)

a)
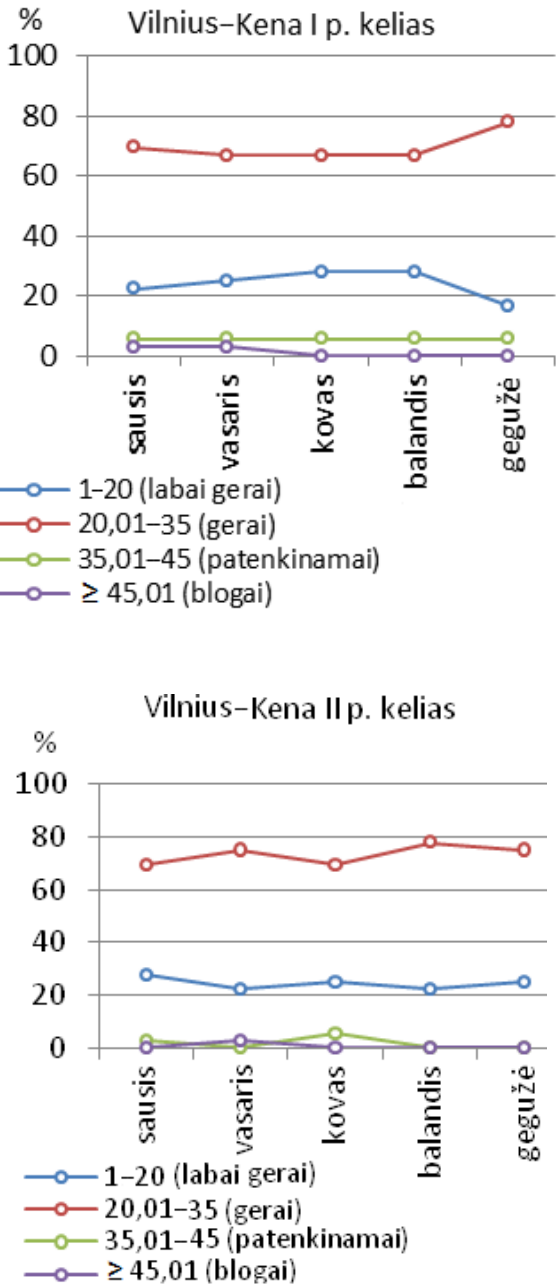

4.5 pav. Pagrindinių kelių Vilnius-Kena procentinis kiekis verčių, atitinkančių KKI:

a) I ir b) II kelio

Fig. 4.5. The percentage of values corresponding to TQI on the main tracks of the route Vilnius-Kena: a) track 1 and b) track 2 
2. Traukinio greitis (važiavimo trukmè). Geležinkelio ruožą Vilnius-KenaValstybès siena (su Baltarusija) sudaro 4 tarpstočiai (4.6 pav.). Ruožo ilgis $L=36 \mathrm{~km}$. Tarpstočių ilgiai $l_{1}=9 \mathrm{~km}, l_{2}=8 \mathrm{~km}, l_{3}=12 \mathrm{~km}, l_{4}=7 \mathrm{~km}$. Didžiausias leidžiamasis traukinio važiavimo greitis ruože Vilnius-Valstybès siena yra $v_{\max , l}=120 \mathrm{~km} / \mathrm{h}$ (Dèl didžiausio leistino traukiniu... 2009). Traukinio mašinisto ispejjamajame lapelyje buvo nurodyta, kad $2012 \mathrm{~m}$. gegužès $17 \mathrm{~d}$. tarpstotyje Kena-Valstybès siena traukinio greitis turi būti ribojamas iki $40 \mathrm{~km} / \mathrm{h}$. Faktiškasis traukinio greitis tarpstočiuose buvo: $v_{f 1}=43 \mathrm{~km} / \mathrm{h}, v_{f 2}=77 \mathrm{~km} / \mathrm{h}, v_{f 3}=57 \mathrm{~km} / \mathrm{h}$, $v_{f 4}=51 \mathrm{~km} / \mathrm{h}$ (vidutinis greitis užrašytas pagal vagono valdymo skydo vaizduoklio rodmenis). Vertinant traukinio greiti (važiavimo trukmę), KKVR dėmeniui skaičiuoti naudojama (2.5) formulè. Gaunama, kad $x_{A 2}=0,473$. Idealiu atveju visu ruožu traukinys važiuos didžiausiu leidžiamuoju greičiu $\left(x_{A 2}=1\right)$. Blogiausiu atveju - viršydamas didžiausią leidžiamaji greiti, o tai yra pavojinga eismo saugumo atžvilgiu arba važiuodamas labai lètai, todèl priimama, $\operatorname{kad} x_{A 2}=0$.

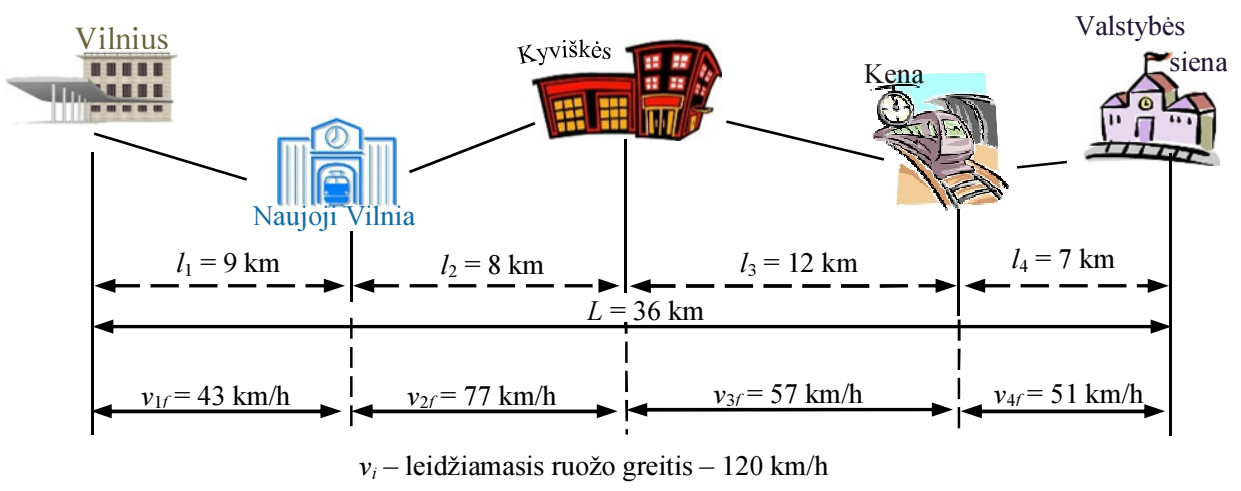

4.6 pav. Kelio ruožo Vilnius-Valstybès siena atskirų tarpstočių ilgiai ir traukinio

Vilnius-Maskva važiavimo šiuo ruožu $2012 \mathrm{~m}$. gegužès $17 \mathrm{~d}$. greičiai

Fig. 4.6. The lengths of intermediate stations on the route Vilnius-State border and the speed of the train 'Vilnius-Moscow', moving on this route on May 17, 2012

3. Išorinè vagono būklè (švara, pažaidos). Sąstate yra 7 vagonai. Visi vagonai prieš išvykimą iš formavimo stoties yra plaunami, todèl švarūs. Ant vagonų kẻbulų nèra pažaidų. Vertinant vagono išorinę būklę (švara, pažaidas), KKVR dėmeniui skaičiuoti naudojama (2.6) formulè. Gaunamas idealus atvejis, kai $x_{A 3}=1$.

4. Triukšmą mažinančios priemonès (priemonès su garso izoliacija). AB „Lietuvos geležinkeliai“ Keleivių vežimo direkcijos, Keleivių aptarnavimo poskyrio $2005 \mathrm{~m}$. lapkričio $24 \mathrm{~d}$. profesinès rizikos nustatymo kortelèje pažymèta, kad traukinyje Vilnius-Maskva, kai dirba 2 palydovai 1 vagone, ekvivalentinis triukšmo lygis (dozè) yra $72 \mathrm{~dB}(\mathrm{~A})$, o restorano vagone $(2007 \mathrm{~m}$. gruodžio $6 \mathrm{~d}$. protokolas) palydovo-bufetininko darbo vietoje (bare) $62 \mathrm{~dB}$ (A). Triukšmo po- 
būdis pagal laiko charakteristiką yra kintantis (nepastovus $\geq 5 \mathrm{~dB}$ ). Sąstate yra 7 vagonai. KKVR dėmeniui skaičiuoti naudojama (2.7) formulè. Gaunama, kad $x_{A 4}=0,188$. Idealiu atveju triukšmo lygis bus lygus $0 \mathrm{~dB}$ (A) $\left(x_{A 4}=1\right)$, o blogiausiu - kai triukšmas viršija ribinę ekspozicijos vertę, gaunama neigiama reikšmè. Priimama, $\operatorname{kad} x_{A 4}=0$.

5. Vagono interjeras. AB ,Lietuvos geležinkeliai“ keleivinių vagonų parko atnaujinimas atliekamas dviem kryptimis: a) naudojamų vagonų eksploatavimo laiko pratęsimas (modernizavimas); b) naujų vagonų isigijimas. Siekiant įsitikinti, jog pasiūlytas interjero vertinimo modelis yra teisingas ir ji galima taikyti praktikoje, atliekamas bandymas pagal tarptautinio traukinio Vilnius-Maskva 20101120 schemą. Sąstate yra 7 vagonai, iš kurių 4 yra nauji, o 3 modernizuoti. KKVR dèmeniui skaičiuoti naudojama (2.8) formulè. Gaunama, $\operatorname{kad} x_{A 5}=0,786$.

6. Vėdinimo, oro kondicionavimo, apšvietimo įrangos veikimas. Sąstate yra 7 vagonai. Šiuo metu ne visuose LG tarptautiniais maršrutais kursuojančiuose vagonuose irengta oro kondicionavimo sistema. 6-uose vagonuose veikia visos (vagono védinimo, oro kondicionavimo, šildymo, apšvietimo) sistemos, o 1ame vagone neirengta oro kondicionavimo sistema (veikia trys sistemos). KKVR dèmeniui skaičiuoti naudojama (2.9) formulè. Gaunama, kad $x_{A 6}=0,964$.

7. Reikiama vagono vidaus temperatūra. Atliekamas bandymas pagal traukinio Vilnius-Maskva schema. Sąstate yra 7 vagonai. Traukinyje VilniusMaskva $2012 \mathrm{~m}$. kovo $22 \mathrm{~d}$. ir $24 \mathrm{~d}$. buvo matuojama miegamojo 4-ių vietų kupé (KV) vagono vidaus oro temperatūra (nuo 16.00 val. iki 7.00 val. (kas 15 min. 61 matavimas) 1-oje ir 9-oje kupè. Vagono vidaus oro temperatūra buvo matuojama skaitmeniniu termometru lauko ir vidaus temperatūrai matuoti (TA20). Aplinkos oro temperatūra buvo užrašoma pagal vagono valdymo skydo vaizduoklio rodmenis. Vagono vidaus ir lauko oro temperatūros kitimas pavaizduotas $4.7(\mathrm{a}, \mathrm{b})$ ir $4.8(\mathrm{a}, \mathrm{b})$ paveiksluose.
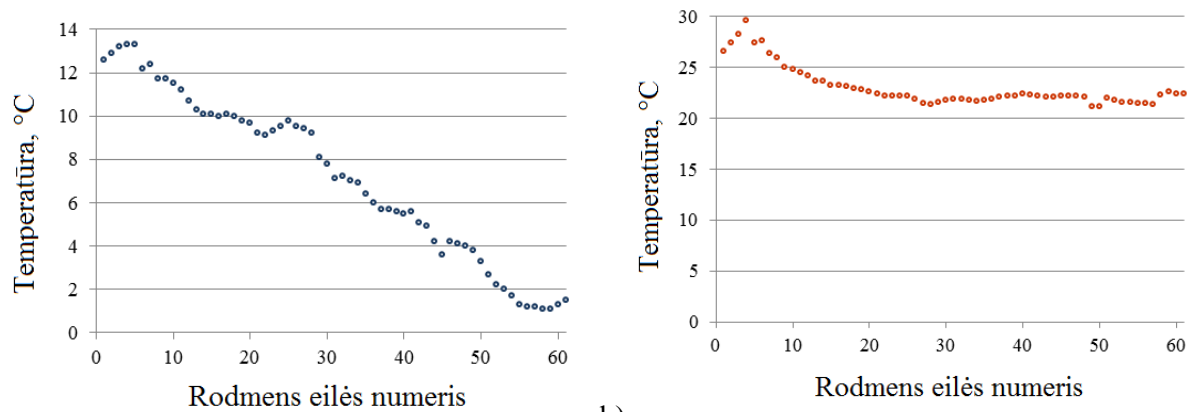

a)

b)

4.7 pav. $2012 \mathrm{~m}$. kovo $22 \mathrm{~d}$. lauko (a) ir KV kategorijos vagono 1-os kupé vidaus (b) temperatūros kitimas

Fig. 4.7. The variation of the outdoor (a) and indoor (b) temperature (in the passenger car compartment 1) on March 22, 2012 
a)
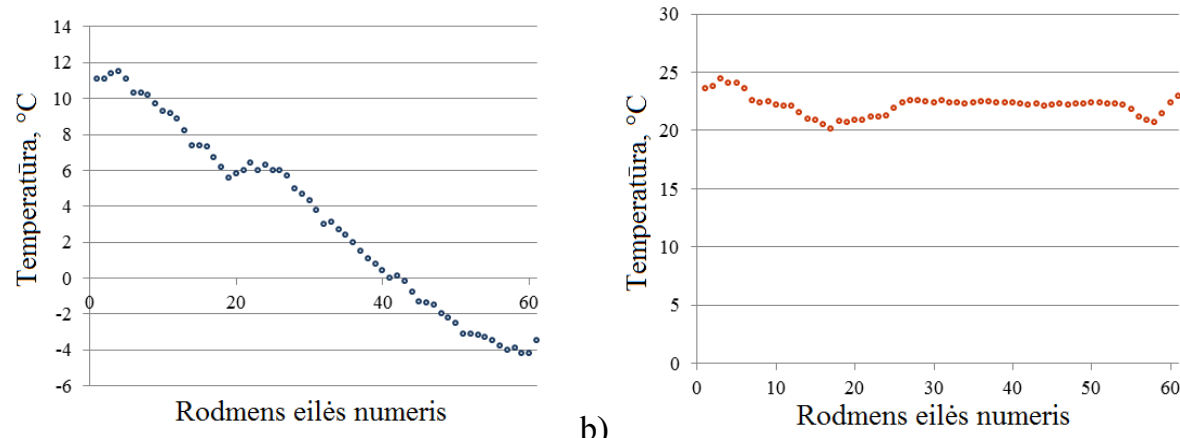

b)

(b) temperatūros kitimas

Fig. 4.8. The variation of the outdoor (a) and indoor (b) temperature (in the passenger car compartment 9) on March 24, 2012

Tyrimų atlikimo laikotarpiu (4.9 ir 4.10 pav.) lauko (aplinkos) oro vidutiné temperatūra buvo $7,23{ }^{\circ} \mathrm{C}$ ir $3,35{ }^{\circ} \mathrm{C}$, t. y. aukštesnè negu $-40{ }^{\circ} \mathrm{C}$. Priimama, kad matavimų datos yra priskirtinos žiemos laikotarpiui. Kovo 22 d. išmatuota vagono vidaus vidutinè temperatūra yra $23{ }^{\circ} \mathrm{C}\left(\bar{T}_{f}=\frac{1402,7}{61}=23\right)$ (4.9 (b) pav.), o 24 d. $-22{ }^{\circ} \mathrm{C}\left(\bar{T}_{f}=\frac{1350,3}{61}\right)=22,14$ (4.10 (b) pav.). Interpoliuojant iš grafiko, (4.9 pav.) atitinkamai kokybès lygis $x_{A 7}=0,750$ ir kitą dieną $(4.10$ pav.) $x_{A 7}=0,965$. Apskaičiuojamas atvejis su realiais duomenimis iš (2.10) formulès žiemos laikotarpiu (kai sąstate visuose vagonuose vanduo šildomas elektra nuo aukštos įtampos (3000 V) kontaktinio tinklo:

1-os kupe matavimai (1 diena):

$$
x_{A 7}=1-\frac{\sum_{c=1}^{V}\left|\frac{\frac{T_{U}+T_{L}}{2}-\bar{T}_{f}}{T_{U}-T_{L}}\right|_{c}}{V}=1-\frac{\left|\frac{\frac{24+20}{2}-23}{24-20}\right|}{7}=0,75 .
$$

9-os kupé matavimai (2 diena):

$$
x_{A 7}=1-\frac{\sum_{c=1}^{V}\left|\frac{\frac{T_{U}+T_{L}}{2}-\bar{T}_{f}}{T_{U}-T_{L}}\right|_{C}}{V}=1-\frac{\left|\frac{\frac{24+20}{2}-22}{24-20}\right|}{7}=1 .
$$



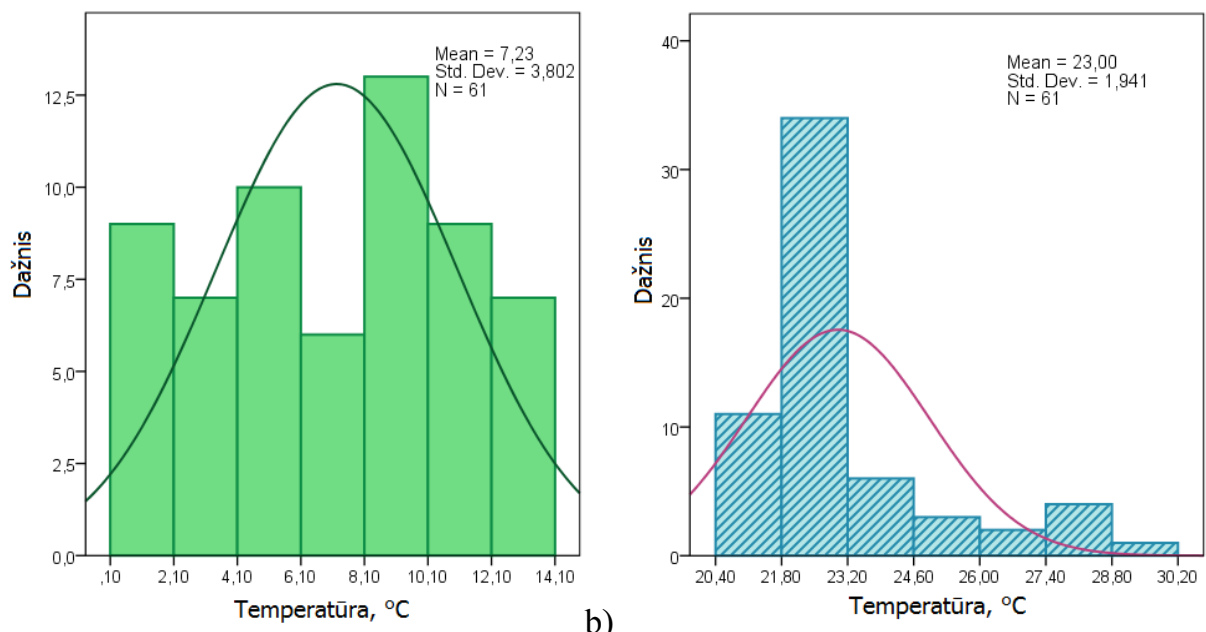

b)

4.9 pav. 2012 m. kovo 22 d. lauko (a) ir KV kategorijos vagono 1-os kupé vidaus

(b) temperatūros matavimų histograma, normalusis skirstinys

Fig. 4.9. The histogram of the outdoor (a) and indoor (b) temperature (in the passenger car compartment 1), measured on March 22, 2012, normal distribution

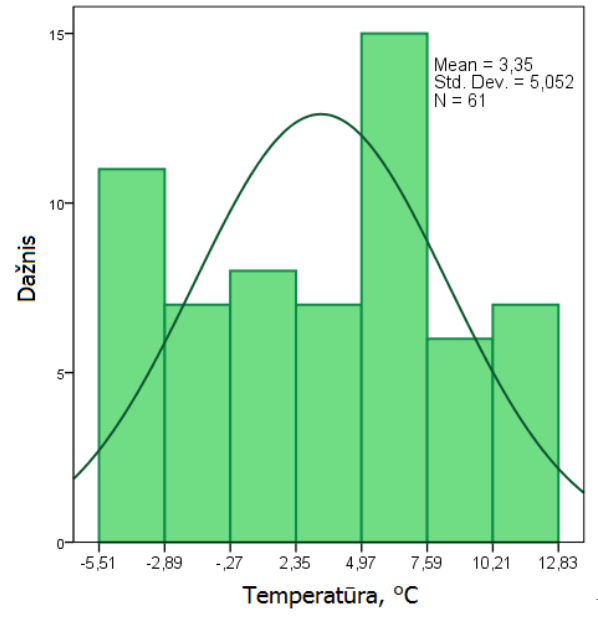

a)

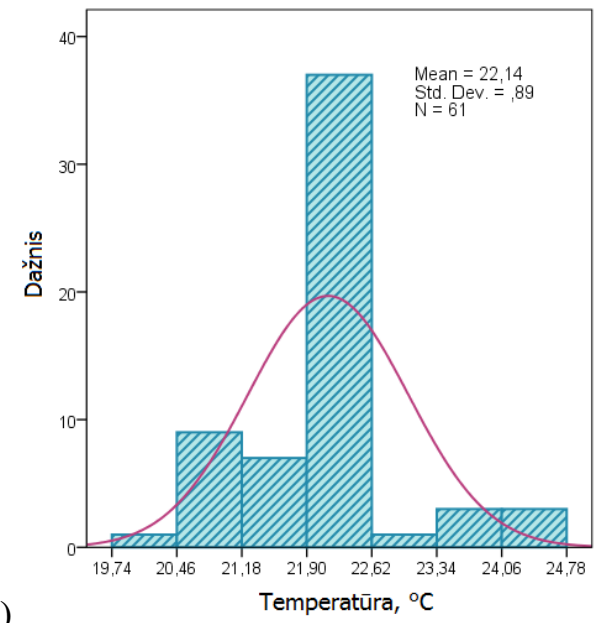

b)

4.10 pav. 2012 m. kovo 24 d. lauko (a) ir KV kategorijos vagono 9-os kupé vidaus

(b) temperatūros matavimų histograma, normalusis skirstinys

Fig. 4.10. The histogram of the outdoor (a) and indoor (b) temperature (in the passenger car compartment 9), measured on March 24, 2012, normal distribution 
Apskaičiuojamas idealus, ribinis ir kritinis atvejai žiemos laikotarpiu (kai sąstate visuose vagonuose vanduo šildomas elektra nuo aukštos itampos $(3000 \mathrm{~V})$ kontaktinio tinklo):

a) idealus atvejis:

$$
x_{A 7}=1-\frac{\sum_{c=1}^{V}\left|\frac{\frac{T_{U}+T_{L}}{2}-\bar{T}_{f}}{T_{U}-T_{L}}\right|_{c}}{V}=1-\frac{\left|\frac{\frac{24+20}{2}-22}{24-20}\right|}{7}=1 ;
$$

b) ribinis atvejis (šalta):

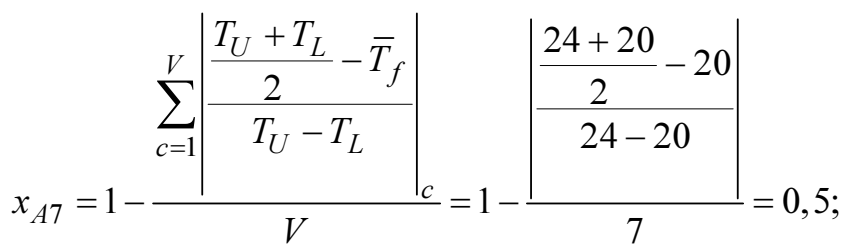

c) kritinis atvejis (neleidžiama):

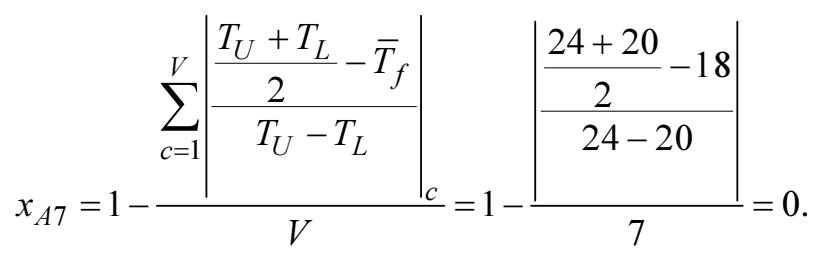

Blogiausias variantas $\left(x_{A 7}=0\right)$ gaunamas tada, kai $\bar{T}_{f}$ yra $2{ }^{\circ} \mathrm{C}$ žemesnè už apatinę leidžiamą ribą $T_{L}$ arba kai $\bar{T}_{f}$ yra $2{ }^{\circ} \mathrm{C}$ didesnè už viršutinę leidžiamą ribą $T_{U}$. Jeigu $\bar{T}_{f}$ daugiau negu $2{ }^{\circ} \mathrm{C}$ mažesnè už $T_{L}$ arba $2{ }^{\circ} \mathrm{C}$ didesnè už $T_{U}$, $x_{A 7}$ reikšmè būtų neigiama, todèl laikoma, $\operatorname{kad} x_{A 7}=0$.

8. Sanitarinių mazgų (tualetų) tipas (atviro tipo ar vakuuminis) ir būklè. Šiuo metu 70 \% LG eksploatuojamų keleivinių vagonų parko įrengti vakuuminiai tualetai. Po 2-4 metu planuojama visuose vagonuose irengti ekologines tualetų sistemas. Sąstate yra 7 vagonai. 6-uose vagonuose tualetai vakuuminiai ir tvarkingai prižiūrimi (vertina traukinio viršininkas), o 1-ame vagone - atviro tipo, tačiau tvarkingi. Vertinant sanitarinių mazgų tipą ir jų būklę, KKVR dèmeniui skaičiuoti naudojama (2.12) formulè. Gaunama, $\operatorname{kad} x_{A 8}=0,893$.

9. Gultų konstrukcija (viršutinių gultų saugos diržai), specialios priemonès neigaliesiems. Kai kurių $\mathrm{AB}$, „Lietuvos geležinkeliai“ KV viršutiniuose gultuose yra irengti apsauginiai laikikliai, o paprastuosiuose miegamuosiuose vago- 
nuose (PV) - saugos diržai. Dalis keleivinių, dyzelinių bei elektrinių traukinių yra pritaikyti specialiems neigalių keleivių poreikiams: yra įrengtos vietos neigaliujų vežimèliams tvirtinti, pritaikyti tualetai, praplatinti iejjimai bei durys. Tokių traukinių nuolat daugejja, nes, atliekant modernizavimo darbus arba isigyjant naujus traukinius, yra atsižvelgiama i neigalių žmonių specialius poreikius. I vagoną keleiviai su vežimèliais įkeliami naudojant mobiliuosius keltuvus, kurie yra didžiosiose geležinkelio stotyse (Prieigos taisyklès... 2010). Traukinio Vilnius-Maskva sąstate yra 6 vagonai. Restorano vagonas i skaičiavimus neịtrauktas. 5-uose vagonuose viršutiniai gultai turi saugos diržus, tačiau vagonai nepritaikyti neigaliems keleiviams, 1-ame vagone yra tik apatiniai gultai (saugos diržai nereikalingi), vagonas nepritaikytas neigaliems keleiviams. KKVR dėmeniui skaičiuoti naudojama (2.13) formulè. Gaunama, $\operatorname{kad} x_{A 9}=0,333$.

10. Irengtas nuolat veikiantis dušas. Šiuo metu LG eksploatuojamuose vagonuose nèra irrengto dušo. Jis ypač reikalingas tiek keleiviams, tiek traukinio darbuotojams tarptautiniuose traukiniuose, kurie važiuoja didesniu atstumu ir kelionè užtrunka ilgiau. KKVR dèmeniui skaičiuoti naudojama (2.14) formulè. Gaunama, $\operatorname{kad} x_{A 10}=0$.

11. Specialios kupė dviračiams vežti. LG tarptautiniuose traukiniuose nèra vagonų, pritaikytų dviračiams vežti, tačiau pagal nešulių vežimo normas leidžiama vežti ne daugiau kaip vieną išardytą ir supakuotą bemotorị dvirati, jei pagal matmenis jis telpa nešuliams skirtoje vietoje (Pagalbine nepriklausomu valstybiu sandraugos šaliu... 2003). Už išardyto ir supakuoto dviračio vežimą mokèti nereikia. KKVR dèmeniui skaičiuoti naudojama (2.15) formulè. Gaunama, $\operatorname{kad} x_{A 11}=0,50$.

12. Rūkyti skirtos vietos. Pagal Lietuvos Respublikos Tabako kontrolès įstatyma, draudžiama rūkyti (ir vartoti kitus tabako gaminius) viešajame transporte (išskyrus tolimojo susisiekimo traukinius, kuriuose turi būti numatyti atskiri vagonai nerūkantiesiems ir rūkantiesiems). AB „Lietuvos geležinkeliai“ tarptautinio susisiekimo traukiniuose rūkoma tam pritaikytose vagonu angainèse. Tokia padètis tenkina ne visus keleivius: rūkant tam skirtose angainèse dūmai neretai prasiskverbia (nesandarios, neuždarytos durys) i vagono saloną. Atliekamas bandymas traukiniui Vilnius-Maskva pagal traukinyje esamą tvarką - rūkoma tam pritaikytose vagonų angainèse. Vertinant rūkyti skirtas vietas, KKVR demeniui skaičiuoti naudojama (2.16) formulè. Gaunama, $\operatorname{kad} x_{A 12}=0,50$.

13. Radijo mazgas ir jo centralizuotas ijungimas ir išjungimas. Radijo garso reguliavimo jungikliai vagonuose irengti kupé, koridoriuje (salone). Šiuo metu $\mathrm{AB}$,Lietuvos geležinkeliai“ eksploatuojamuose naujuose $\mathrm{KV}$, pagamintuose Tverès vagonų gamykloje (Rusija), keliaujančiujų patogumui vagono kupė irengtos ausinių jungtys. Jeigu ausinių keleiviai neturi (neišduoda vagono palydovas), jie priversti klausytis radijo transliacijos, jeigu net to ir nenori. Šiame vagone radijas jjungiamas ir išjungiamas jungikliu, kuris yra palydovo darbo 
kupè. Šiuo jungikliu negalima reguliuoti garso intensyvumo. Traukiniui išvykus iš pradinès stoties, dèl per didelio garso, keleiviai prašo palydovo radiją išjungti, todèl negirdi informacijos apie traukinio maršruta, kurią teikia traukinio viršininkas. Sąstate yra 6 vagonai (restorano vagonas i skaičiavimus neįtrauktas). KKVR demeniui skaičiuoti naudojama (2.17) formulè. Gaunama, kad $x_{A 13}=0,50$.

14. Restorano vagonas. Visuose LG tarptautiniuose traukiniuose yra restorano vagonas. Jame yra prekiaujama alkoholiniais gèrimais. Palydovas-bufetininkas, atliekantis restorano vagone padavejo darba, taupymo sumetimais yra skiriamas retai, todèl yra savitarna arba padavejo darbą atlieka restorano vagone dirbantis palydovas. Vagonų palydovai siūlo keleiviams kavos, arbatos, gaiviujų gèrimų, konditerijos gaminių. Keleiviui pageidaujant, vagono palydovas privalo iš restorano vagono atnešti norimų patiekalų, gerimų. Bandymas atliktas traukiniui VilniusMaskva. KKVR demeniui skaičiuoti naudojama (2.18) formulè. Gaunama, kad $x_{A 14}=0,875$.

15. Palydovo skubaus iškvietimo i kupé galimybè. Palydovo skubaus iškvietimo ị kupé jungikliai yra ne visuose šiuo metu AB „Lietuvos geležinkeliai“ naudojamuose vagonuose. Naujuose KV, pagamintuose Tverès vagonų gamykloje (Rusija), keliaujančiujuc patogumui vagono kupe irengti palydovo skubaus iškvietimo jungikliai, tačiau jie veikia tik tada, kai i kortelių skaitytuvą yra ịstatyta magnetinè kortelè. Kol kas tokios kortelès nèra naudojamos, todèl ir iškviesti palydovą i kupé nèra galimybès. Atliekamas bandymas traukiniui VilniusMaskva pagal (2010 1120 ) schemą. Sąstate yra 6 vagonai (restorano vagonas i skaičiavimus neitrauktas). KKVR dèmeniui skaičiuoti naudojama (2.19) formulè. Gaunama, $\operatorname{kad} x_{A 15}=0,417$.

16. Galimybè pasinaudoti plaukų džiovintuvu, drabužių lygintuvu. Lietuvos formavimo traukiniuose nèra ịrengtos buitinès kupé, kurioje būtų galimybè pasinaudoti plaukų džiovintuvu, drabužių lygintuvu. Vertinant galimybę traukinyje pasinaudoti plaukų džiovintuvu, drabužiu lygintuvu, KKVR dèmeniui skaičiuoti naudojama (2.20) formulè. Gaunama, $\operatorname{kad} x_{A 16}=0,25$.

Visų A grupès kriterijų kokybès lygmuo ir ji atitinkantis kintamojo dydžio $x_{A j}$ ivertis su realiais duomenimis pateiktas 4.1 lentelèje. Kokybès lygmuo ir ji atitinkantis kintamojo dydžio $x_{A j}$ jivertis su puikiais duomenimis yra 1 , su vidutiniais duomenimis yra 0,5 , su labai blogais duomenimis -0 .

Iš (2.21) formulès apskaičiuojamas kriterijų, susietų su traukinio elementais ir kelio technine būkle, daugiakriteris rodiklis $K_{A}$ :

$$
\begin{aligned}
K_{A}= & 0,228 \cdot(0,0400 \cdot 0,646+0,1035 \cdot 0,473+0,0307 \cdot 1+0,0562 \cdot 0,188+ \\
& 0,0560 \cdot 0,786+0,0997 \cdot 0,964+0,1042 \cdot 0,75+0,0813 \cdot 0,893+ \\
& 0,0624 \cdot 0,333+0,0709 \cdot 0+0,0345 \cdot 0,50+0,0360 \cdot 0,50+ \\
& 0,0450 \cdot 0,50+0,0822 \cdot 0,875+0,0359 \cdot 0,417+0,0452 \cdot 0,25)=0,133 .
\end{aligned}
$$


4.1 lentelè. A grupès kriterijų kokybès lygmuo ir ji atitinkantis kintamojo dydžio $x_{A j}$ ivertis su realiais duomenimis

Table 4.1. Quality level of the criteria of group A and the respective value of the variable $x_{A j}$ based on real data

\begin{tabular}{|c|c|c|}
\hline $\begin{array}{l}\text { A grupès kriterijų kin- } \\
\text { tamieji dydžiai } x_{A j} \text { ir } \\
\text { skaičiuojamosios for- } \\
\text { mulès numeris }\end{array}$ & Dėmens reikšmė & $\begin{array}{l}\text { Apskaičiuotoji } \\
\text { vertė }\end{array}$ \\
\hline 1 & 2 & 3 \\
\hline$x_{A 1}(2.4)$ & $\frac{\sum_{s=1}^{N_{k m}}\left(1-\frac{K K I_{f}^{2}}{K K I_{r i b}^{2}}\right)_{s}}{N_{k m}}=\frac{23,244}{36}$ & 0,646 \\
\hline$x_{A 2}(2.5)$ & $\begin{array}{l}l_{1}=9 \mathrm{~km}, \quad l_{2}=8 \mathrm{~km}, \quad l_{3}=12 \mathrm{~km}, \quad l_{4}=7 \mathrm{~km} \\
(L=36) \mathrm{km} ; \quad v_{\max , l}=120 \mathrm{~km} / \mathrm{h} ; \quad v_{f 1}=43 \mathrm{~km} / \mathrm{h} \\
v_{f 2}=77 \mathrm{~km} / \mathrm{h}, v_{f 3}=57 \mathrm{~km} / \mathrm{h}, v_{f 4}=51 \mathrm{~km} / \mathrm{h}\end{array}$ & 0,473 \\
\hline$x_{A 3}(2.6)$ & $V K B_{f}=2\left(1,2, \ldots, 7^{*}\right) ; V K B_{\max }=2 ; \quad V=7$ & 1 \\
\hline$x_{A 4}(2.7)$ & $\begin{array}{l}T L_{f}=72 \mathrm{~dB}\left(1,2, \ldots, 6^{*}\right) \\
T L_{f}=62 \mathrm{~dB}\left(7^{*}\right) ; T L_{l}=87 \mathrm{~dB} ; V=7\end{array}$ & 0,188 \\
\hline$x_{A 5}(2.8)$ & $I_{f}=2\left(1,2,3,4^{*}\right) ; I_{f}=1\left(5,6,7^{*}\right) ; I_{\max }=2 ; V=7$ & 0,786 \\
\hline$x_{A 6}(2.9)$ & $\begin{array}{l}V K A_{f}=4\left(1,2, \ldots, 6^{*}\right) ; V K A_{f}=3\left(7^{*}\right) \\
V K A_{\max }=4 ; V=7\end{array}$ & 0,964 \\
\hline$x_{D 7}(2.10)$ & $T_{U}=24 ; T_{L}=20 ; \bar{T}_{f}=23 ; \quad V=7$ & 0,75 \\
\hline$x_{A 8}(2.12)$ & $\begin{array}{l}W C_{f}=4\left(1,2, \ldots, 6^{*}\right) ; \quad W C_{f}=1(7 *) ; \quad W C_{\max }=4 \\
V=7\end{array}$ & 0,893 \\
\hline$x_{A 9}(2.13)$ & $G_{f}=3\left(6^{*}\right) ; G_{f}=1\left(1,2, \ldots, 5^{*}\right) ; G_{\max }=4 ; V=6$ & 0,333 \\
\hline$x_{A 10}(2.14)$ & $D_{f}=0\left(1,2, \ldots, 7^{*}\right) ; D_{\max }=2 ; V=7$ & 0 \\
\hline$x_{A 11}(2.15)$ & $D V_{f}=2 ; D V_{\max }=4$ & 0,50 \\
\hline$x_{A 12}(2.16)$ & $R V_{f}=1 ; R V_{\max }=2$ & 0,50 \\
\hline$x_{A 13}(2.17)$ & $\begin{array}{l}R M_{f}=3\left(1,2,3^{*}\right) ; \quad R M_{f}=1\left(4,5,6^{*}\right) ; \quad R M_{\max }=4 \\
V=6\end{array}$ & 0,50 \\
\hline$x_{A 14}(2.18)$ & $V R_{f}=7 ; V R_{\max }=8$ & 0,875 \\
\hline$x_{A 15}(2.19)$ & $\begin{array}{l}P I_{f}=2\left(1^{*}\right) ; \quad P I_{f}=1\left(2,3,4^{*}\right) ; \quad P I_{f}=0\left(5,6^{*}\right) \\
P I_{\max }=2 ; V=6\end{array}$ & 0,417 \\
\hline$x_{A 16}(2.20)$ & $D L_{f}=1 ; \quad D L_{\max }=4$ & 0,25 \\
\hline
\end{tabular}

Pastaba: (c-ojo vagono*) 
Gaunama, kad kriterijų, susietų su traukinio elementais ir geležinkelio kelio technine būkle, rodiklis $K_{A}=0,133$, t. y. A grupès kriterijų itaka KTK, išreikšta vienu parametru.

\subsection{Kriterijų, susietų su kelionès traukiniu proceso organizavimu ir technologija, modelio praktinio pritaikymo vertinimas}

1. Traukinių išvykimas ir atvykimas laiku. Atliekamas bandymas pagal traukinio Vilnius-Maskva važiavimo grafiką. Traukinio važiavimo trukmè nuo pradinės A stoties iki galinès D stoties yra 14 val. 58 min. (898 minutès). Pradinèje, Vilniaus stotyje, i traukini illipo 91 keleivis. Iš jų 77 važiavo iki galinès stoties Maskvos. Iš viso reise važiavo 102 keleiviai. Gaunama, kad vẻlavimo išvykti iš išvykimo (pradinès) A ir atvykti ị galinę D stotị svorio koeficientas $\gamma=0,75$ (2.24 formulè). Kelio ruože Vilnius-Maskva yra 8 tarpinès stotys, kuriose sustoja traukinys (K priedas). Traukinys iš Vilniaus išvyko laiku, pagal grafiką atvyko į Kenos pasienio stoti, tačiau iš čia išvyko 2 min. vèliau negu numatyta grafike (stovèjo 37 minutes). I Gudagu pasienio stotị atvyko pavèlavęs 2 min., stovejo $38 \mathrm{~min}$. ( 2 min. trumpiau nei numatyta tvarkaraštyje), todèl iš Gudagų išvyko laiku. Traukinys ị Smargonių ir Maladzečno stotis atvyko laiku ir laiku iš jų išvyko. I Minską atvyko pavèlavęs $3 \mathrm{~min}$. ir išvyko $3 \mathrm{~min}$. vèliau. I Oršą ir Smolenską atvyko laiku ir laiku išvyko. I Viazmą atvyko pavèlavęs $5 \mathrm{~min}$., stovejjo trumpiau - $18 \mathrm{~min}$., todèl išvyko laiku. I galinę, Maskvos stoti, atvyko pagal grafiką. Vertinant traukinio važiavimą, KKVR dèmeniui skaičiuoti naudojama (2.23) formulè. Kadangi traukinys iš pradinès stoties išvyksta laiku, o vèlavimai $\mathfrak{i}$ kai kurias tarpines stotis ir iš jų nèra dideli, gaunamas rezultatas, artimas 1 , t. y. $x_{B 1}=0,832$. Maršrutas (reisas) laikomas idealiu $\left(x_{B 1}=1\right)$, kai traukinys nevèluoja atvykti (išvykti) nei į vieną stoti, t. y. važiuoja tiksliai pagal grafiką. Jis yra vidutinis, kai i kiekvieną stoti traukinys véluoja 5 minutes. Laikomasi tokios nuostatos, kad blogiausias traukinio vèlavimo variantas yra toks, kai traukinys, išvykęs iš pradinès stoties, tuoj pat sustojo ir stovejo tiek, kiek trunka kelionè iki galinès (paskirties) stoties. Tokiu atveju gali būti suformuotas kitas traukinys keleiviams vežti, tačiau pirmasis reisas yra niekinis ir priimama, kad $x_{B 1}=0$. Grupès B kriterijų kokybės lygmuo ir ji atitinkantis kintamojo dydžio $x_{B j}$ jivertis su realiais duomenimis pateikti 4.2 lentelèje.

2. Maisto davinio keleiviams pateikimas už i bilietą iskaičiuotą kainą. Traukinyje Vilnius-Maskva yra 6 vagonai (restorano vagonas i skaičiavimus neitrauktas). Šiuo metu LG tarptautiniuose traukiniuose maisto davinys pateikiamas už i bilietą iskaičiuotą kainą tik minkštujų dviviečių kupe vagonų (MV) keleiviams. Vertinant maisto davinio keleiviams pateikimą už i bilietą iskaičiuotą kainą, KKVR dèmeniui skaičiuoti naudojama (2.25) formulè. Gaunama, $\operatorname{kad} x_{B 2}=0,083$. 


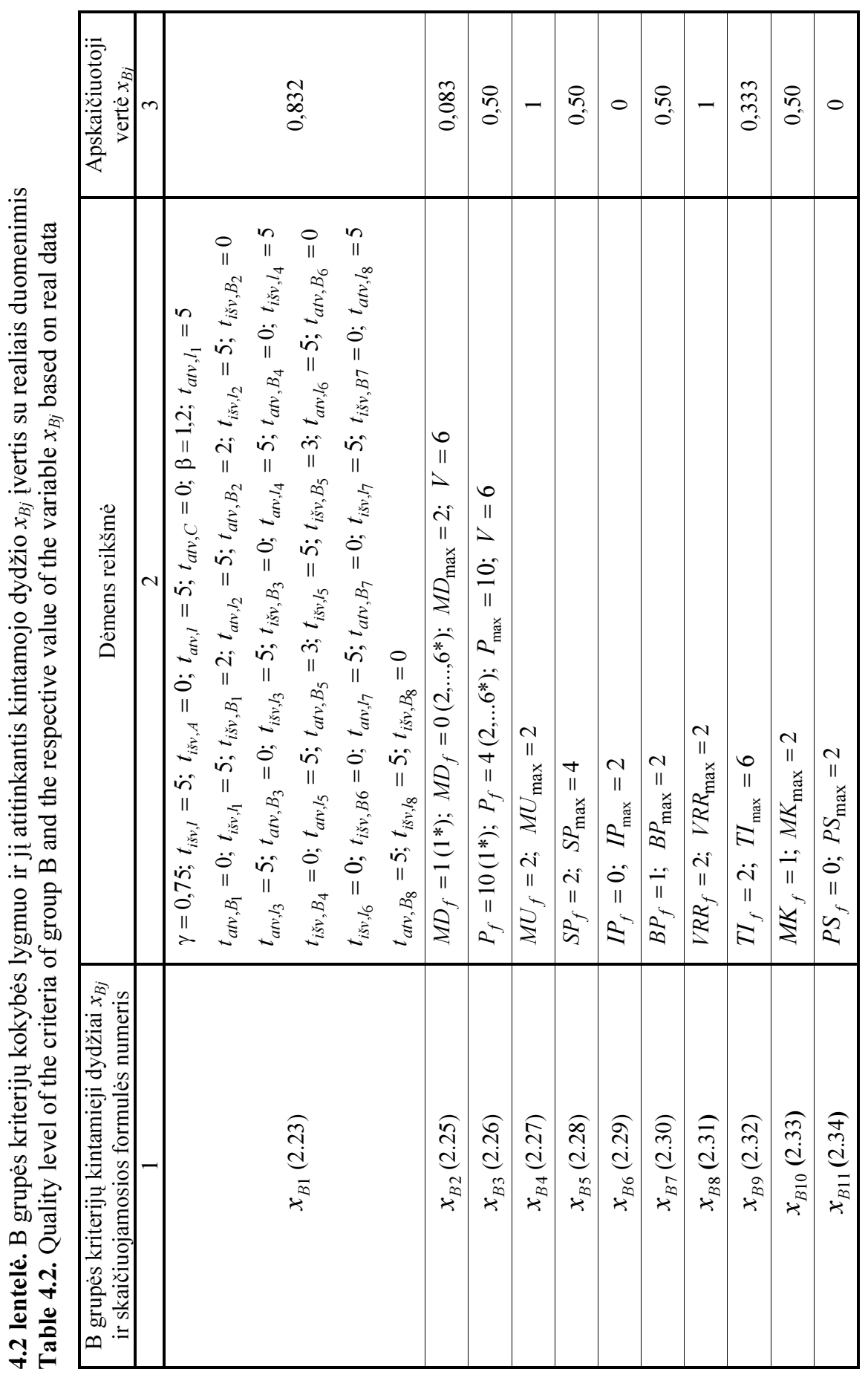




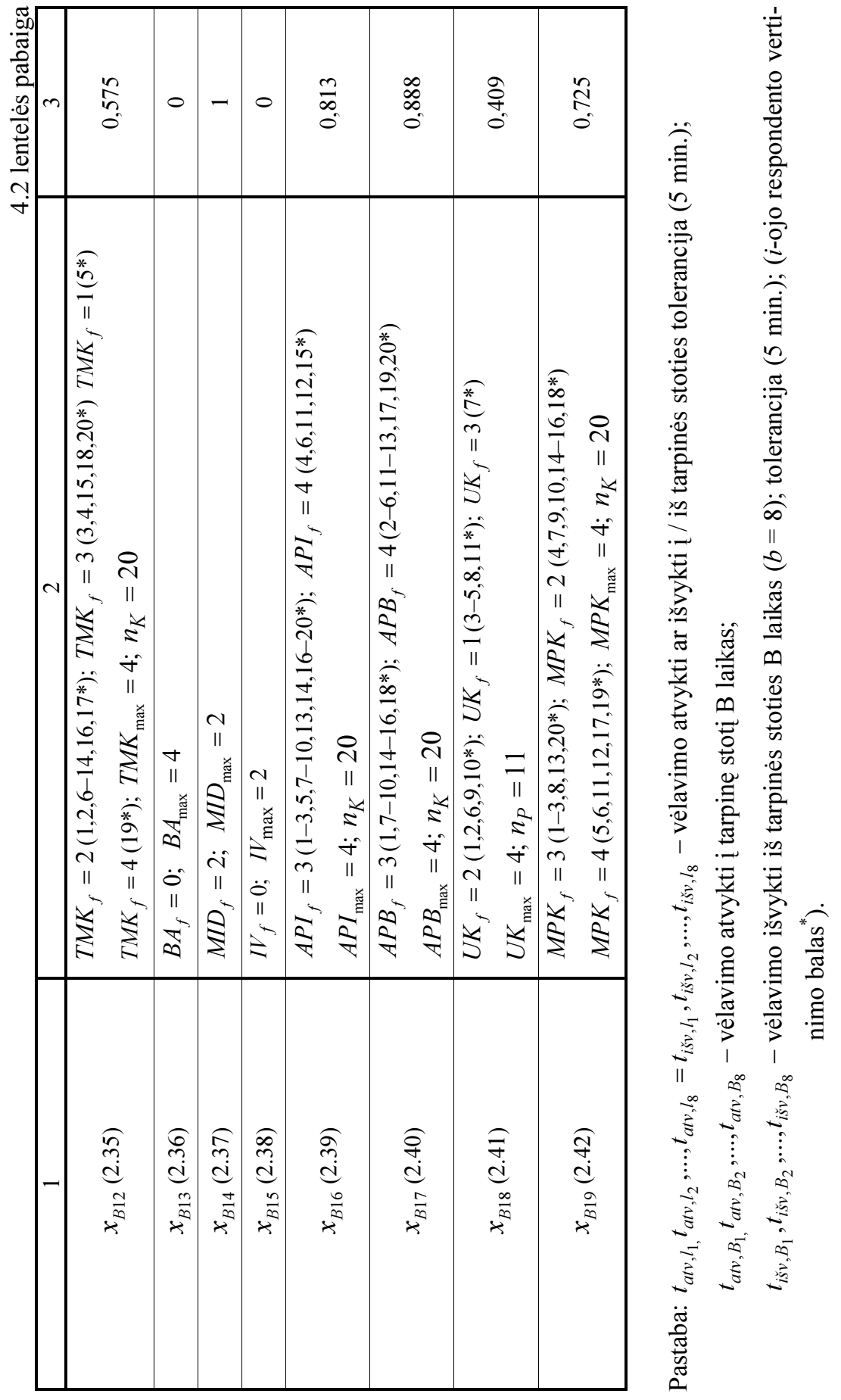


3. Patalynès pateikimas, paklojimas ir jos būklè. Vertinant patalynès pateikimą, paklojimą ir jos būklę remiamasi tuo, kad AB ,Lietuvos geležinkeliai" tarptautiniuose traukiniuose patalynès komplektas (dvi paklodès, pagalvès užvalkalas ir vienas rankšluostis) keleiviui pateikiamas už i bilietą įskaičiuotą kainą visų kategorijų vagonuose. Patalynès komplektas turi būti specialioje nepažeistoje pakuoteje. Keleiviui pageidaujant vagono palydovas privalo patalynę pakloti. MV vagonuose patalynè paklojama ruošiant vagoną reisui, prieš ilipant keleiviams. Traukinyje Vilnius-Maskva yra 6 vagonai (restorano vagonas $\mathfrak{i}$ skaičiavimus neitrauktas). KKVR dèmeniui skaičiuoti naudojama (2.26) formule. Gaunamas vidutinis atvejis $x_{B 3}=0,5$.

4. Maisto ir gerimų užsakymo iš restorano ir atnešimo i kupe galimybe (per vagono palydova). Kiekviename traukinio vagone yra meniu. Keleiviui pageidaujant vagono palydovas privalo atnešti i kupe maisto ir gérimų iš restorano vagono. Traukinyje Vilnius-Maskva yra 6 vagonai (restorano vagonas į skaičiavimus neįtrauktas). KKVR dèmeniui skaičiuoti naudojama (2.27) formulè. Gaunamas idealus atvejis $x_{B 4}=1$.

5. Populiariosios spaudos platinimas traukinyje. Lietuvos geležinkelių traukiniuose dienraščių kaina yra tokia, kaip spaudos kioskuose. Kai kurie dienraščiai yra mokami, kai kurie nemokami. KKVR demeniui skaičiuoti naudojama (2.28) formulè. Gaunama $x_{B 5}=0,50$.

6. Prieiga prie interneto. LG traukiniuose nèra prieigos prie interneto. KKVR dèmeniui skaičiuoti naudojama (2.29) formulè. Gaunamas kritinis atvejis $x_{B 6}=0$.

7. Kelionès bilieto pirkimo traukinyje galimybè (iš traukinio viršininko). LG tarptautiniame traukinyje Vilnius-Maskva keleivis, nesuspèjęs nusipirkti bilieto kasoje, gali nusipirkti bilietą iš traukinio viršininko ir užimti vieta, priklausančią traukinio viršininko rezervui KV vagone. KKVR demeniui skaičiuoti naudojama (2.30) formule. Gaunamas vidutinis atvejis $x_{B 7}=0,5$.

8. Vietų restorano vagone rezervavimo galimybè. LG tarptautiniuose traukiniuose keleivis gali rezervuoti vietą restorano vagone. Šia galimybe keleiviai naudojasi retai. Traukinyje Vilnius-Maskva keleivis gali rezervuoti vietą restorano vagone, nepriklausomai nuo to, kokios kategorijos vagone jis važiuoja. KKVR dèmeniui skaičiuoti naudojama (2.31) formule. Gaunamas idealus atvejis $x_{B 8}=1$.

9. Taksi paslaugos traukinyje užsakymas. LG formavimo traukiniuose keleivis gali iškviesti taksi per vagono palydovą ir traukinio viršininką prieš traukiniui atvykstant i galinę (formavimo stoti). Už taksi iškvietimą mokèti nereikia. Traukinyje Vilnius-Maskva keleivis gali iškviesti nemokamai taksi per vagono palydovą ir traukinio viršininką. KKVR demeniui skaičiuoti naudojama (2.32) formule. Gaunama $x_{B 9}=0,333$. 
10. Galimybė traukinyje atsiskaityti mokejjimo kortele. Keleiviai, už traukiniuose teikiamas paslaugas, prekes ir kelionès bilietus (tarptautiniuose traukiniuose) gali atsiskaityti mokejimo kortelemis. EKS yra irengtas restorano vagone. Traukinyje Vilnius-Maskva keleivis gali atsiskaityti mokejjimo kortele, tačiau jis privalo nueiti į restorano vagona, kuriame įrengtas EKS. KKVR dèmeniui skaičiuoti naudojama (2.33) formulè. Gaunamas vidutinis atvejis $x_{B 10}=0,50$.

11. Prekyba suvenyrais traukinyje. AB ,Lietuvos geležinkeliai“ traukiniuose suvenyrais neprekiaujama. KKVR demeniui skaičiuoti naudojama (2.34) formulè. Gaunamas kritinis atvejis $x_{B 11}=0$.

12. Traukinyje transliuojamų muzikos kūrinių, informacijos atitiktis keleivių norams. $A B$ „Lietuvos geležinkeliai“ traukiniuose yra transliuojamos radijo laidos, leidžiami muzikiniai ir informaciniai (apie kelionès trukmę, stotis, kuriose sustos traukinys, teikiamas traukinyje paslaugas ir kt.) irašai. Šie irašai yra reglamentuoti. Atliekamas bandymas traukiniui Vilnius-Maskva pagal 20 keleivių užpildytų anketų duomenis. Anketos pavyzdys yra pateiktas A priede. KKVR dèmuo skaičiuojamas pagal (2.35) formulę. Gaunama, $\operatorname{kad} x_{B 12}=0,575$.

13. Keleivių bagažo ir daiktų apsauga. Šiuo metu LG tarptautiniuose traukiniuose seifai sumontuoti tik MV vagonuose, tačiau jie nèra skirti keleivių daiktams saugoti. Traukinyje Vilnius-Maskva keleivio bagažas, dokumentai ir kiti daiktai nèra saugomi, už jų saugumą atsako pats keleivis. KKVR dèmuo skaičiuojamas pagal (2.36) formulę. Gaunamas kritinis atvejis $x_{B 13}=0$.

14. Užsienio medicininių išlaidų draudimo įsigijimo traukinyje galimybè. $\mathrm{AB}$,Lietuvos geležinkeliai“ tarptautiniuose traukiniuose issigyti užsienio medicininių išlaidų draudimą šiuo metu nèra galimybès ir poreikio, nes į užsienį ketinantis keliauti asmuo draudžiamas vizos išdavimo metu. KKVR dèmuo skaičiuojamas pagal (2.37) formulę. Gaunamas idealus atvejis $x_{B 14}=1$.

15. Vizos įsigijimo pasienio punkte galimybè. Vizos pasienio punkte neišduodamos. Keleivis, neturintis vizos arba yra pasibaigęs (neprasidejęes) jos galiojimo laikas, iš traukinio pasienio punkte turi išlipti. Jis privalo vykti i vizu išdavimo punktą ir gavęs vizą tęsti kelionę kitu traukiniu. Keleivis sugaišta daug laiko, neretai patiria stresą. Atliekamas bandymas traukiniui Vilnius-Maskva, kai pasienio punkte (per kuri važiuoja traukinys) nėra galimybès isigyti vizos. KKVR dèmuo skaičiuojamas pagal (2.38) formulę. Gaunamas blogiausias atvejis $x_{B 15}=0$.

16. Aptarnaujančio personalo išvaizda (uniformos apranga, avalynè, šukuosena, vardine kortelè). Reikalavimai darbuotojų išvaizdai yra nurodyti $\mathrm{AB}$ „Lietuvos geležinkeliai“" Keleivių vežimo direkcijos keleivių aptarnavimo standartuose (2012). Atliekamas bandymas traukiniui Vilnius-Maskva pagal 20 keleivių užpildytų anketų duomenis. Anketos pavyzdys yra pateiktas A priede. KKVR demuo skaičiuojamas pagal (2.39) formulę. Gaunama, $\operatorname{kad} x_{B 16}=0,813$.

17. Aptarnaujančio personalo bendravimo kultūra su keleiviais ir tarpusavyje. Atliekamas bandymas traukiniui Vilnius-Maskva pagal 20 keleivių užpil- 
dytų anketų duomenis. Anketos pavyzdys pateiktas A priede. KKVR dėmeniui skaičiuoti naudojama (2.40) formulè. Gaunama, kad $x_{B 17}=0,888$.

18. Aptarnaujančio personalo užsienio kalbos mokejjimas. Tarptautinio susisiekimo traukinio viršininkas (vyresnysis palydovas) privalo mokèti užsienio kalbą tiek, kad galètų bendrauti su keleiviais ir geležinkelio, per kurį važiuoja traukinys, administracija (Tarptautinio susisiekimo keleivinio... 2003). Vagonų palydovai privalo mokèti susikalbèti viena ar daugiau užsienio kalbų. Atliekamas bandymas traukiniui Vilnius-Maskva pagal 11-os traukini aptarnaujančių darbuotojų ( 1 traukinio viršininkas ir 10 vagono palydovų) žodinès apklausos (apklause traukinio viršininkas) duomenis. KKVR demeniui skaičiuoti naudojama (2.41) formulè. Gaunama, $\operatorname{kad} x_{B 18}=0,409$.

19. Muitinès ir pasienio pareigūnų kompetencija, objektyvumas ir bendravimo su keleiviais kultūra. Atliekamas bandymas traukiniui Vilnius-Maskva pagal 20 keleivių užpildytų anketų duomenis (A priedas). Vertinant muitinès ir pasienio pareigūnų kompetencija, objektyvumą ir bendravimo su keleiviais kultūra, KKVR dèmeniui skaičiuoti naudojama (2.42) formulè. Gaunama, kad $x_{B 19}=0,725$.

Visų B grupès kriterijų kokybės lygmuo ir ji atitinkantis kintamojo dydžio $x_{B j}$ ịvertis su realiais duomenimis pateiktas 4.2 lentelèje. Kokybès lygmuo ir ji atitinkantis kintamojo dydžio $x_{B j}$ ivertis su puikiais duomenimis yra 1, su vidutiniais duomenimis yra 0,5 , su labai blogais duomenimis -0 .

Pagal (2.43) formulę apskaičiuojamas kriterijų, susietų su kelionès traukiniu proceso organizavimu ir technologija, daugiakriteris rodiklis $K_{B}$ :

$$
\begin{aligned}
K_{B}= & 0,228 \cdot(0,1072 \cdot 0,832+0,0293 \cdot 0,083+0,0509 \cdot 0,50+ \\
& 0,0300 \cdot 1+0,0276 \cdot 0,50+0,0401 \cdot 0+0,0600 \cdot 0,50+0,0221 \cdot 1+ \\
& 0,0219 \cdot 0,333+0,0467 \cdot 0,50+0,0180 \cdot 0+0,0262 \cdot 0,575+ \\
& 0,0898 \cdot 0+0,0587 \cdot 1+0,1030 \cdot 0+0,0560 \cdot 0,813+0,0794 \cdot 0,888+ \\
& 0,0507 \cdot 0,409+0,0826 \cdot 0,725)=0,115 .
\end{aligned}
$$

Gaunama, kad kriterijų, susietų su kelionès traukiniu proceso organizavimu ir technologija, grupès rodiklis $K_{B}=0,115$, t. y. B grupès kriterijų itaka KTK, išreikšta vienu parametru.

\subsection{Kriteriju, susietų su kelionès kaina, modelio praktinio pritaikymo vertinimas}

1. Bilieto kaina. $\mathrm{AB}$ „Lietuvos geležinkeliai“ vietinio vežimo baziniai tarifai nustatomi pagal keleivinių vagonų paslaugos klasę (2 klasè, 3 klasė) ir traukinių greičio kategoriją (greitieji, paprastieji traukiniai). Keleivių vežimo kaina nèra 
diferencijuojama pagal traukos rūši ir geležinkelio linijas. Traukinyje VilniusMaskva yra $V_{P}$ (1 vagonas), $V_{K}$ (4 vagonai) ir $V_{M}$ (1 vagonas) kategorijų vagonai. Yra nustatyti vežimo kainos bazinio tarifo indeksacijos koeficientai (Lietuvos ir Baltarusijos geležinkelių pastovūs, Rusijos - kintantys pagal kalendorinị laikotarpi). Siekiant racionaliau reguliuoti vagonų užimtumą skirtingomis savaitès dienomis bei padidinti gaunamas pajamas už keleivių vežimą tarptautiniuose traukiniuose LG nustatyti vietos kainų (pagal savaitės dienas) koeficientai. Apatinès vietos kaina yra didesnè už viršutinès vietos kainą. Mažiausia bilietų kaina yra gegužès 8-9 dienomis, didžiausia - 28-29 balandžio, 8-12 birželio, 13 liepos ir 2 rugsejo, 2-5 lapkričio, 29-30 gruodžio dienomis. Atliekamas testas. Sąstate yra 6 vagonai. KKVR dèmeniui skaičiuoti naudojama (2.45) formulè, kuri pagal traukinio Vilnius-Maskva vagonų kategorijas užrašoma taip:

$$
x_{C 1}=\frac{\frac{V_{P} \cdot\left(1-\frac{B K_{f P}-B K_{\min P}}{B K_{\max P}-B K_{\min P}}\right)+V_{K} \cdot\left(1-\frac{B K_{f K}-B K_{\min K}}{B K_{\max K}-B K_{\min K}}\right)+}{+V_{M} \cdot\left(1-\frac{B K_{f M}-B K_{\min M}}{B K_{\max M}-B K_{\min M}}\right)}}{V},
$$

čia: $V$ - sąstato vagonų skaičius $\left(V=V_{P}+V_{K}+V_{M}\right) ; V_{P}, V_{K}, V_{M}-2$ klasès paprastujų miegamujų, 2 klasès miegamujų 4-ių vietų kupè ir 1 klasės minkštujų 2jų vietų kupe sąstato vagonų skaičius; $B K_{f P}, B K_{\min P}, B K_{\max P}-\mathrm{V}_{\mathrm{P}}$ kategorijos vagono faktinè, mažiausia ir didžiausia bilieto kaina; $B K_{f K}, B K_{\min K}, B K_{\max K}-\mathrm{V}_{\mathrm{K}}$ kategorijos vagono faktinè, mažiausia ir didžiausia bilieto kaina; $B K_{f M}, B K_{\min M}$, $B K_{\max M}-\mathrm{V}_{\mathrm{M}}$ kategorijos vagono faktiné, mažiausia ir didžiausia bilieto kaina.

4.1 formuleje naudojamos $V_{P}$ ir $V_{K}$ kategoriju vagonų kainos yra imamos kaip apatinès ir viršutinès vietų kainų vidurkis. $V_{M}$ kategorijos vagone tik apatinès vietos, kurių kaina yra vienoda. Bilietų kainos keičiasi pagal metų laikotarpi. 2012 m. gegužès $11 \mathrm{~d}$. kainos yra paimtos kaip faktinès, gegužès 9 d. kaip mažiausios ir birželio $8 \mathrm{~d}$. kaip didžiausios bilietų kainos. Gaunama, kad $x_{C 1}=0,287$ (su realiais duomenimis). Idealiu atveju, kai $B K_{f y}=B K_{\min y}$, gaunama $x_{C 1}=1$. Blogiausiu atveju, kai $B K_{f y}=B K_{\max y}$, gaunama $x_{C 1}=0$.

2. Restorane parduodamų patiekalu kaina. Traukinyje atlikto tyrimo metu (2011 04 13) nustatyta, kad pigesni patiekalai yra populiaresni (4.11 pav.). Sriubos, kurios kaina $4 \mathrm{Lt}$, nupirkta daugiausiai - 22 porcijos. Perkami ir brangesni patiekalai, kurie kainuoja 18 ir 19 Lt. Patiekalai, kainuojantys 20 ir 25 Lt, nèra labai paklausūs. Traukinyje atlikta žodinè keleivių apklausa (apklausė traukinio viršininkè) parodè, kad restorano vagone parduodamu patiekalų kokybę dauguma keleivių vertina labai gerai (3 balai).

KKVR demeniui skaičiuoti naudojamos (2.46)-(2.50) formulès. Restorano vagone parduodamų patiekalų kaina bus vertinama pagal (2.46) formulę. Kai 
$P K_{\min }=4 \mathrm{Lt}, P K_{d}=4 ; 6 ; 6,50 ; 8 ; 9 ; 17 ; 18 ; 19 ; 20 ; 25 \mathrm{Lt}, J_{d}=22 ; 5 ; 9 ; 10 ; 9 ; 5$; $15 ; 12 ; 5 ; 5 \mathrm{Lt}$, o $J_{1}+J_{2}+\ldots+J_{u}=97$, gaunama, $\operatorname{kad} P K=0,339$. Vertinant maisto patiekalų kokybę naudojama (2.47) formulè. Kai $B_{M K 0}=0, B_{M K 1}=1, B_{M K 2}=2$, $B_{M K 3}=3, B_{M K 4}=4$, o $n_{0}=0, n_{1}=5, n_{2}=3, n_{3}=23, n_{4}=29, \quad\left(n_{1}+n_{2}+\ldots+\right.$ $\left.n_{i}\right)=60$, gaunama, kad $R M K=0,817$. Vertinant asortimento gausą naudojama (2.48) formulè. Kai $A G_{f}=14$, o $A G_{\max }=24, A G=0,583$. Patiekalų keitimo periodiškumas vertinamas pagal (2.49) formulę: $P K P_{f}=1, P K P_{\max }=4$. Gaunama, kad $P K P=0,25$. Su realiais duomenimis $x_{C 2}=0,497$ (2.50) formulè). Idealiu atveju, kai $P K_{\min }=4 \mathrm{Lt}, d$-ojo patiekalo kaina $P K_{d}=4 \mathrm{Lt}, J_{d}=22 ; 5 ; 9 ; 10 ; 9$; $5 ; 15 ; 12 ; 5 ; 5 \mathrm{Lt}$, o $J_{1}+J_{2}+\ldots+J_{u}=97$, gaunama $P K=1$. Kai $B_{M K 0}=0$, $B_{M K 1}=1, B_{M K 2}=2, B_{M K 3}=3, B_{M K 4}=4$, o $n_{0}=0, n_{1}=0, n_{2}=0, n_{3}=0, n_{4}=60$, $\left(n_{1}+n_{2}+\ldots+n_{i}\right)=60$, gaunama, kad $R M K=1$. Kai $A G_{f}=24$ ir $A G_{\max }=24$, $A G=1$. Kai $P K P_{f}=4$, o $P K P_{\max }=4, P K P=1$. Tada $x_{C 2}=1$. Tiketina, kad blogiausias atvejis bus tada, kai restorano vagone nebus galima pavalgyti, pvz., techninio gedimo atveju. Tuomet priimama, $\operatorname{kad} P K=0$. Kai $B_{M K 0}=0, B_{M K 1}=1$, $B_{M K 2}=2, \quad B_{M K 3}=3, \quad B_{M K 4}=4, \quad$ o $\quad n_{0}=60, \quad n_{1}=0, \quad n_{2}=0, \quad n_{3}=0, \quad n_{4}=0$, $\left(n_{1}+n_{2}+\ldots+n_{i}\right)=60$, gaunama, kad $R M K=0$. Kai $A G_{f}=0$ (patiekalu restorano vagone nèra), o $A G_{\max }=24, A G=0$. Kai $P K P_{f}=0$ (patiekalai nekeičiami), o $P K P_{\max }=4$, gaunama, $\operatorname{kad} P K P=0$. Tada gaunama, $\operatorname{kad} x_{C 2}=0$.

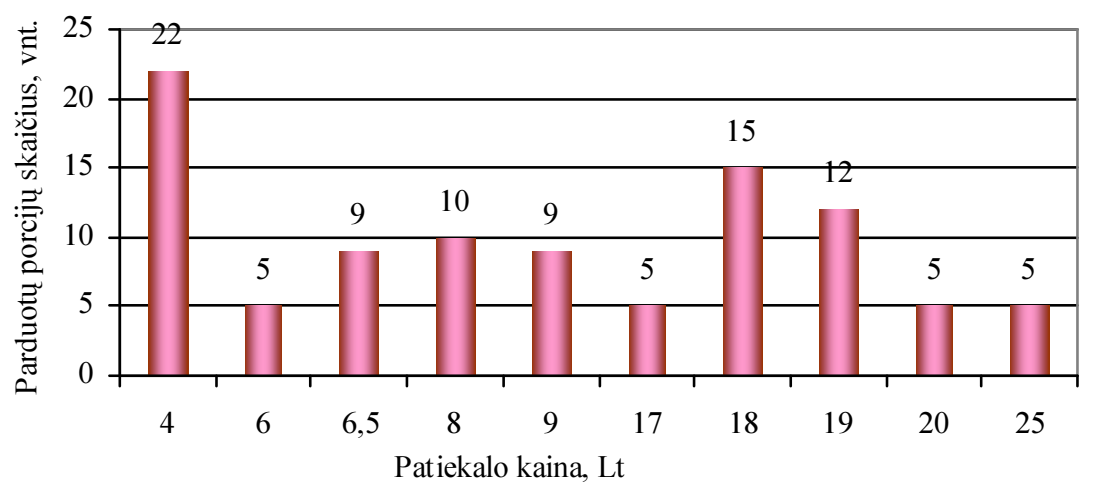

4.11 pav. Patiekalo paklausos priklausomybè nuo patiekalo kainos

Fig. 4.11. The dependence of the demand for a dish on its cost

3. Laikraščių ir žurnalų kaina. Spaudos kaina traukinyje yra tokia pati, kaip spaudos kioskuose. KKVR dèmeniui skaičiuoti naudojama (2.51) formulè. Gaunamas vidutinis atvejis $x_{C 3}=0,50$.

4. Užsienio medicinos išlaidų draudimo kaina. Lietuvos Respublikos piliečiui, ketinančiam vykti į Rusiją (pvz., traukiniu Vilnius-Maskva), reikalingas užsienio medicinos išlaidų draudimas. Draudimo trukmè yra 1-3 dienos, o imo- 
ka - 8 Lt. Mažiausias tarifas būtinosios medicinos pagalbos draudimo atveju yra $6 \mathrm{Lt}$, o didžiausias - 12 Lt. KKVR dèmeniui skaičiuoti naudojama (2.52) formulè. Gaunama, kad $x_{C 4}=0,667$. Idealiu atveju, kai $M I D_{f}=M I D_{\min }$, gaunama $x_{C 4}=1$. Blogiausiu atveju, kai $M I D_{f}=M I D_{\max }, x_{C 4}=0$.

5. Vizų kaina. Keleiviui, Lietuvos Respublikos piliečiui, važiuojančiam traukiniu Vilnius-Maskva i Rusiją, reikalingos dvi vizos - Baltarusijos Respublikos tranzitine ir Rusijos Federacijos viza. Vizos būna ịvairių tipų (turistinès, komercinès) ir laikotarpių (vienkartinès, dvikartinès, daugkartinès). Imama, kad keleiviui reikalinga Rusijos turistinè vienkartinè (iki 30 dienu) ir Baltarusijos Respublikos tranzitinè vienkartinè viza. Forminimo terminas 6-7 darbo dienos. KKVR dèmeniui skaičiuoti naudojama (2.53) formulè. Gaunama, kad $x_{C 5}=0,804$ (su realiais duomenimis). Idealiu atveju, kai $V K_{f B}=V K_{\min B}, \quad$ o $V K_{f R}=V K_{\min R}$, gaunama $x_{C 5}=1$. Blogiausiu atveju, kai $V K_{f B}=V K_{\max B}$, o $V K_{f R}=V K_{\max R}$, gaunama $x_{C 5}=0$.

4.3 lentelè. C grupès kriterijų kokybès lygmuo ir ji atitinkantis kintamojo dydžio $x_{C j}$ ivertis su realiais duomenimis

Table 4.3. Quality level of the criteria of group $\mathrm{C}$ and the respective value of the variable $x_{C j}$ based on real data

\begin{tabular}{|c|c|c|}
\hline $\begin{array}{c}\text { C grupès kriterijų kinta- } \\
\text { mieji dydžiai } x_{C j} \text { ir skai- } \\
\text { čiuojamosios formulès } \\
\text { numeris }\end{array}$ & Dėmens reikšmė & $\begin{array}{l}\text { Apskaičiuo- } \\
\text { toji vertė } x_{C j}\end{array}$ \\
\hline 1 & 2 & 3 \\
\hline$x_{C 1}(2.45)$ ir $(4.1)$ & $\begin{array}{l}B K_{f P}=241,26 ; B K_{\min P}=203,51 \\
B K_{\max P}=256,34 ; B K_{f K}=351,69 \\
B K_{\min K}=279,95 ; B K_{\max K}=380,39 \\
B K_{f M}=677,46 ; B K_{\min M}=534,05 \\
B K_{\max M}=734,80 ; V_{P}=1 ; V_{K}=4 ; V_{M}=1\end{array}$ & 0,287 \\
\hline$x_{C 2}(2.50)$ & $\begin{array}{l}P K=0,339 ; R M K=0,817 ; A G=0,583 \\
P K P=0,25\end{array}$ & 0,497 \\
\hline$x_{C 3}(2.51)$ & $L \check{Z}_{f}=1 ; L \check{Z}_{\max }=2$ & 0,50 \\
\hline$x_{C 4}(2.52)$ & $M I D K_{f}=8 ; M I D K_{\min }=6 ; M I D K_{\max }=12$ & 0,667 \\
\hline$x_{C 5}(2.53)$ & $\begin{array}{l}V K_{f B}=70 ; V K_{\min B}=65 ; V K_{\max B}=85 \\
V K_{f R}=220 ; V K_{\min R}=200 \\
V K_{\max R}=340 ; n_{W}=2\end{array}$ & 0,804 \\
\hline$x_{C 6}(2.54)$ & $M P_{f}=2 ; M P_{\max }=2$ & 1 \\
\hline
\end{tabular}


6. Keleivinio vagono su dvivietemis kupè maisto davinio (iskaičiuoto į bilieto kaina) pateikimas. Šiuo metu AB „Lietuvos geležinkeliai“ tarptautiniuose traukiniuose maisto davinys (vakarienè ir pusryčiai) pateikiamas už i bilietą iskaičiuotą kainą tik MV kategorijos vagono keleiviams. Vertinant šio vagono maisto davinio pateikima, KKVR demeniui skaičiuoti naudojama (2.54) formulè. Gaunama, $\operatorname{kad} x_{C 6}=1$.

Visų C grupès kriterijų kokybès lygmuo ir ji atitinkantis kintamojo dydžio $x_{C j}$ ỉvertis su realiais duomenimis, pateiktas 4.3 lentelèje. Kokybès lygmuo ir ji atitinkantis kintamojo dydžio $x_{C j}$ ivertis su puikiais duomenimis yra 1 , su vidutiniais duomenimis yra 0,5 , su labai blogais duomenimis -0 .

Pagal (2.55) formulę apskaičiuojamas kriterijų, susietų su kelionės kaina, daugiakriteris rodiklis $K_{C}$ :

$$
\begin{aligned}
K_{C}= & 0,2580 \cdot(0,3258 \cdot 0,287+0,0982 \cdot 0,497+0,0551 \cdot 0,50+ \\
& 0,1517 \cdot 0,667+0,2844 \cdot 0,804+0,0849 \cdot 1)=0,151 .
\end{aligned}
$$

Gaunama, kad kriterijų, susietų su kelionès kaina, grupès rodiklis $K_{C}=0,151$, t. y. C grupès kriterijų itaka KTK, išreikšta vienu parametru.

\subsection{Kriterijų, susietu su kelionès traukiniu saugumu, modelio praktinio pritaikymo vertinimas}

1. Gaisro gesinimo priemonių buvimas. Sąstate yra 7 vagonai. Juose yra visos gaisro gesinimo priemoniu rūšys, išskyrus $V_{P}$ vagoną, kuriame nèra UPS. KKVR dėmuo skaičiuojamas pagal (2.57) formulę. Gaunama, kad $x_{D 1}=0,971$.

2. Pirmosios medicinos pagalbos priemoniu buvimas. AB „Lietuvos geležinkeliai“ traukiniuose yra pirmosios medicinos pagalbos priemonés, pvz., neštuvai, vaistinèlè, kurioje yra ịvairūs tvarsčiai. Vaistų vaistinèlèje nèra, išskyrus priemonę nudegimams gydyti. Vaistinèlè yra traukinio viršininko darbo kupè. Traukinio vaistinèlëje esančių tvarsčių nepakaktų ekstremaliais atvejais, pvz., ivvykus teroristiniam aktui. Testas išspręstas remiantis AB „Lietuvos geležinkeliai“ traukiniuose esančia padètimi dèl pirmosios medicinos pagalbos priemonių. KKVR demeniui skaičiuoti naudojama (2.58) formulè. Gaunama, $\operatorname{kad} x_{D 2}=0,50$.

3. Greitosios medicinos pagalbos iškvietimo galimybè. Šiuo metu traukiniuose yra naudojamos nešiojamosios KENWOOD TK-250 radijo stotys, taip pat mobilieji telefonai. AB „Lietuvos geležinkeliai“ yra įdiegtas radijo ryšys, kuris ịvertintas aukso medaliu konkurse „Lietuvos metu gaminys 2010“. Radijo ryšio ir bevielio duomenų perdavimo sistema (GSM-R) apima 1563,3 km geležinkelių linijų. Ši sistema ne tik užtikrina aukštą teikiamų paslaugų kokybę, bet ir leidžia gerokai našiau atlikti vagonų skirstymo, manevravimo, geležinkelių 
kelių priežiūros darbus. Ši sistema suteiks traukinio viršininkui galimybę tiesiogiai susisiekti su artimiausios stoties budètoju, eismo tvarkdariu, keleiviu aptarnavimo poskyrio operatoriumi. Traukinių viršininkai yra išmokyti naudotis šiuo radijo ryšiu. GSM-R pakeite iki tol $A B$,Lietuvos geležinkeliai“ naudotas ryšio priemones, kurios buvo nesertifikuotos ir neatitiko Ryšių reguliavimo tarnybos ir Europos Sajungos keliamų reikalavimų. KKVR dèmeniui skaičiuoti naudojama (2.59) formulè. Gaunama, $\operatorname{kad} x_{D 3}=0,50$.

4. Ašidežiu ikaitimo kontrolès signalizacijos veikimas. Sąstate yra 7 vagonai. Stotyse, kuriose traukinys stovi ilgiau kaip 5 minutes, visų vagonų palydovai privalo patikrinti ašidèžiu ikaitimą iš perono pusès, jei traukinys stovi ilgiau kaip 10 minučių - iš abiejų pusių (Keleivinio vagono palydovo... 1999). Traukinys Kenos, Gudagu, Minsko, Oršos ir Viazmos stotyse stovi daugiau kaip 10 minučių (K priedas), todèl vagonu ašidèžès buvo tikrinamos iš abiejų vagonų pusių. Vagonų ašiděžių, išmatuotų temperatūrų infraraudonujų spindulių termometru (4.12 pav.), temperatūros kaita pateikta 4.4 lentelèje. KKVR dèmeniui skaičiuoti naudojama (2.60) formulè. Gaunama, $\operatorname{kad} x_{D 4}=1$.

Nors vienai traukinio vagono AKAK temperatūrai viršijus kritinę vertę, kyla pavojus ne tik to aširačio kakliukui lūžti ir vagonui nueiti nuo bejgių, bet ir visam traukiniui patirti katastrofą. Manoma, kad vertinti traukinio kokybę pagal visų aširačių AKAK faktinès temperatūros atitiktị kritinei temperatūrai, skaičiuojant vidutines vertes, nèra logiška. Viso sąstato kokybę pagal temperatūrą reikia vertinti pagal blogiausią AKAK vertę ir neskaičiuoti aritmetinių nei kitokių vidurkių (geometrinių, svertinių).

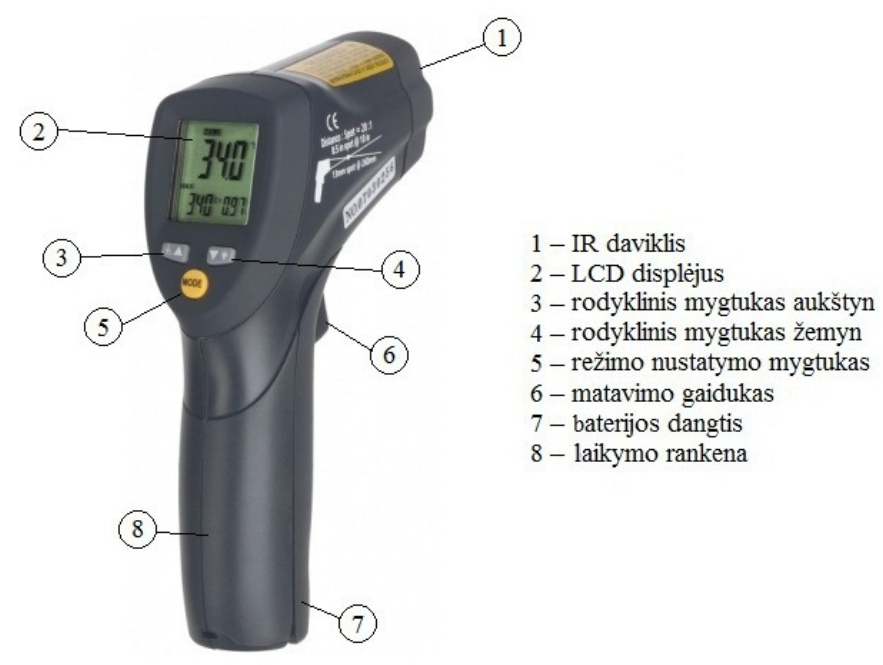

4.12 pav. Infraraudonujų spindulių termometras

Fig. 4.12. Infrared thermometer 
4.4 lentelè. Vagonų ašidèžių, išmatuotų temperatūrų infraraudonujų spindulių termometru, temperatūros kaita

Table 4.4. The variation of the car axle box temperature, measured by infrared thermometer

\begin{tabular}{|c|c|c|c|c|c|c|c|c|c|c|c|}
\hline \multirow{4}{*}{$\begin{array}{l}\text { Vagono eil. } \\
\text { Nr. pagal } \\
\text { schemą }\end{array}$} & \multirow{4}{*}{$\begin{array}{l}\text { Vagono } \\
\text { pusé }\end{array}$} & \multicolumn{10}{|c|}{ Stotys } \\
\hline & & \multicolumn{2}{|c|}{ Kena } & \multicolumn{2}{|c|}{ Gudagai } & \multicolumn{2}{|c|}{ Minskas } & \multicolumn{2}{|c|}{ Orša } & \multicolumn{2}{|c|}{ Viazma } \\
\hline & & \multicolumn{10}{|c|}{ Lauko temperatūra } \\
\hline & & \multicolumn{2}{|c|}{$+22^{\circ} \mathrm{C}$} & \multicolumn{2}{|c|}{$+20^{\circ} \mathrm{C}$} & \multicolumn{2}{|c|}{$+16^{\circ} \mathrm{C}$} & \multicolumn{2}{|c|}{$+9^{\circ} \mathrm{C}$} & \multicolumn{2}{|c|}{$+3^{\circ} \mathrm{C}$} \\
\hline \multirow{4}{*}{1} & \multirow{2}{*}{ I } & 21,1 & 22,2 & 21,0 & 22,0 & 14,5 & 16,1 & 3,9 & 4,2 & 4,2 & 2,0 \\
\hline & & 21,6 & 21,3 & 21,4 & 21,1 & 17,1 & 14,8 & 3,7 & 3,8 & 2,3 & 1,0 \\
\hline & \multirow{2}{*}{ II } & 21,0 & 22,3 & 19,9 & 22,1 & 14,2 & 15,8 & 4,0 & 4,3 & 4,4 & 2,1 \\
\hline & & 21,4 & 21,2 & 21,1 & 19,8 & 16,9 & 15,0 & 3,9 & 3,9 & 2,5 & 1,6 \\
\hline \multirow{4}{*}{3} & \multirow{2}{*}{ I } & 21,4 & 21,9 & 21,2 & 21,6 & 16,5 & 16,0 & 6,3 & 6,2 & 2,1 & 2,8 \\
\hline & & 20,9 & 22,5 & 20,1 & 22,2 & 16,1 & 18,2 & 8,1 & 5,4 & 8,1 & 3,6 \\
\hline & \multirow{2}{*}{ II } & 21,2 & 21,9 & 21,0 & 21,2 & 16,4 & 15,9 & 6,4 & 6,5 & 2,7 & 3,0 \\
\hline & & 20,7 & 22,3 & 20,5 & 22,0 & 15,7 & 18,0 & 8,3 & 5,9 & 7,5 & 3,2 \\
\hline \multirow{4}{*}{4} & \multirow{2}{*}{ I } & 22,8 & 22,8 & 22,4 & 22,3 & 19,3 & 18,3 & 9,7 & 8,0 & 2,6 & 0,3 \\
\hline & & 21,0 & 21,2 & 19,8 & 21,0 & 19,0 & 15,6 & 9,5 & 9,7 & 4,4 & 2,5 \\
\hline & \multirow{2}{*}{ II } & 22,9 & 21,9 & 22,5 & 21,6 & 18,9 & 18,1 & 9,6 & 8,2 & 2,1 & 1,2 \\
\hline & & 21,2 & 21,3 & 19,7 & 19,8 & 18,5 & 16,2 & 9,7 & 9,6 & 3,9 & 2,6 \\
\hline \multirow{4}{*}{5} & \multirow{2}{*}{ I } & 24,5 & 21,7 & 24,1 & 21,2 & 15,6 & 15,2 & 8,1 & 10,6 & 1,9 & 1,7 \\
\hline & & 22,6 & 22,3 & 22,3 & 22,0 & 16,4 & 18,2 & 10,1 & 9,9 & 2,2 & 1,5 \\
\hline & \multirow{2}{*}{ II } & 24,6 & 21,8 & 24,2 & 21,5 & 15,7 & 15,0 & 8,3 & 10,7 & 1,7 & 1,2 \\
\hline & & 23,0 & 22,4 & 22,8 & 22,1 & 15,9 & 17,8 & 10,0 & 10,1 & 2,0 & 1,1 \\
\hline \multirow{4}{*}{$\begin{array}{c}\text { Restorano } \\
\text { vagonas }\end{array}$} & I & 23,2 & 21,8 & 22,8 & 21,3 & 18,3 & 13,4 & 8,4 & 8,9 & 1,9 & 1,5 \\
\hline & 1 & 21,9 & 23,2 & 21,2 & 22,9 & 16,6 & 17,5 & 8,2 & 8,1 & 1,6 & 1,7 \\
\hline & U & 23,3 & 21,9 & 23,1 & 21,4 & 18,5 & 14,0 & 8,6 & 8,8 & 1,6 & 1,2 \\
\hline & 11 & 21,7 & 23,4 & 21,3 & 23,1 & 17,1 & 16,9 & 8,4 & 8,2 & 1,2 & 1,4 \\
\hline & I & 25,3 & 25,1 & 24,9 & 24,8 & 17,4 & 16,3 & 8,3 & 7,2 & 0,7 & 0,5 \\
\hline 6 & 1 & 24,8 & 24,8 & 24,5 & 24,6 & 18,0 & 18,7 & 7,9 & 7,6 & 1,0 & 2,2 \\
\hline 0 & U & 25,7 & 25,0 & 25,4 & 24,7 & 17,1 & 17,0 & 8,5 & 7,4 & 0,9 & 0,7 \\
\hline & 11 & 24,6 & 24,7 & 24,1 & 24,3 & 18,4 & 18,2 & 8,1 & 7,7 & 1,5 & 1,9 \\
\hline & I & 23,8 & 22,3 & 23,5 & 21,9 & 23,7 & 20,9 & 9,1 & 9,0 & 7,0 & 4,8 \\
\hline 16 & 1 & 23,2 & 22,8 & 22,8 & 21,8 & 20,7 & 22,0 & 8,7 & 8,9 & 2,8 & 5,9 \\
\hline 10 & I & 23,5 & 21,9 & 23,1 & 21,4 & 24,1 & 21,0 & 9,3 & 9,5 & 7,2 & 5,1 \\
\hline & II & 23,6 & 22,5 & 23,2 & 22,1 & 21,0 & 21,9 & 8,9 & 9,1 & 3,1 & 5,7 \\
\hline
\end{tabular}

Iš 4.13 paveikslo matyti, kad didejjant aplinkos oro temperatūrai, didejja ir ribine AKAK temperatūra. Yra tiesinè priklausomybè.

Jeigu AKAK temperatūra artèja nuo idealios ribinès link, tai yra pavojus, kad ši tendencija ir toliau gali tęstis ir dažniausiai to priežastis yra nežinoma, bet tikètina, kad ji pasieks ribinę vertę ir ją viršys, todèl kitimas yra nepageidautinas (4.14 pav.). 


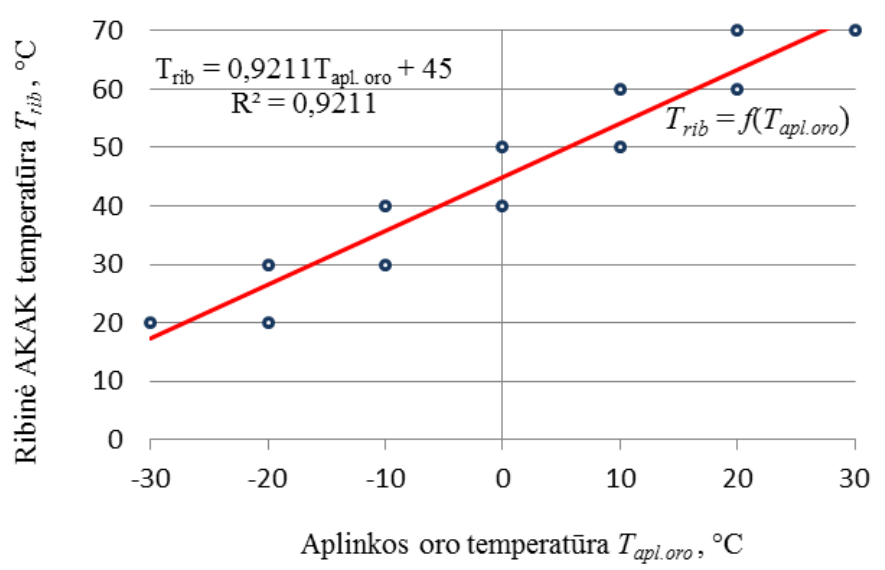

4.13 pav. Aplinkos oro temperatūros kitimo įtaka ribinei AKAK temperatūrai

Fig. 4.13. The influence of the outdoor temperature variation on the limiting AKAK temperature

Manoma, kad sietis yra netiesinè. Esant tiesinei priklausomybei ir vidutiniškai kokybei $T_{f}$ apskaičiuojamas pagal formulę:

$$
T_{f}=\frac{\left(T_{r i b}-T_{\text {apl.oro }}\right)}{2}+T_{\text {apl.oro }} .
$$

Tuomet $T_{f}=43,62{ }^{\circ} \mathrm{C}$, o $T_{\text {apl.oro }}=22^{\circ} \mathrm{C}$. Skaičiuojant pagal (2.60) formulę, gaunama, kad $x_{D 4}=0,5$. Tikètina, $\operatorname{kad} T_{f}$ pasiekus toki lygmeni, kokybès lygis $x_{D 4}$ yra daug mažesnis negu pusè, t. y. apytiksliai $x_{D 4}=0,25$, tačiau tam įrodyti reikalingi išsamūs papildomi moksliniai tyrimai.

Ašidèžių kaitimo įtaka kelionès traukiniu kokybei su realiais duomenimis skaičiuojama pagal (2.60) formulę. Kenos stotyje (4.4 lentelè) 1-mo vagono, I vagono pusès ašidèžių temperatūra $T_{f}=21,1$. Priimama, kad $T_{f}=T_{\text {apl.oro. Aplin- }}$ kos oro temperatūra $T_{\text {apl.oro }}=22{ }^{\circ} \mathrm{C}$. Gaunama, $\operatorname{kad} x_{D 4}=1$. Tai yra idealus atvejis. Ašidèžių kaitimo itaka kelionès traukiniu kokybei su labai blogomis reikšmèmis, kai $T_{\text {apl.oro }}=22{ }^{\circ} \mathrm{C}$, o $T_{f}=T_{r i b}$. Gaunama, kad $x_{D 4}=0$. Priimama, kad $x_{D 4}=0$.

5. Avarinių išèjimų buvimas. Sąstate yra 7 vagonai. KKVR dėmeniui skaičiuoti naudojama (2.61) formulè. Gaunama, $\operatorname{kad} x_{D 5}=1$.

6. Turèklų, laipteliu, perẻjimo aikštelių, durų ir spynų tvarkingumas. Vertinami traukinio Vilnius-Maskva 7 vagonai. KKVR dèmuo skaičiuojamas pagal (2.62) formulę. Gaunamas idealus atvejis $x_{D 6}=1$. 
7. Rankinio stabdžio veikimas ir būklè, stabdų būklè. Vertinami traukinio Vilnius-Maskva 7 vagonai. KKVR dèmeniui skaičiuoti naudojama (2.63) formulè. Gaunama, $\operatorname{kad} x_{D 7}=1$.

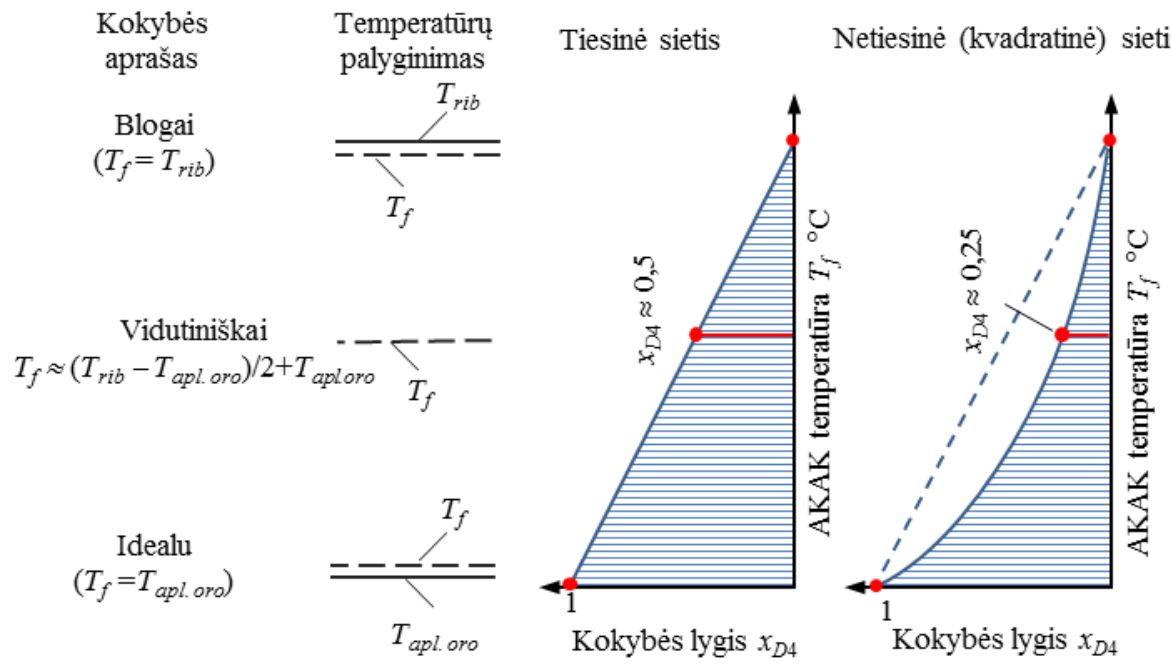

4.14 pav. Keleivinio traukinio AKAK temperatūros įtakos

jo kokybès rodikliui $Q_{D 4} \times x_{D 4}$ grafinis modelis

Fig. 4.14. Graphical model of the influence of the passenger train AKAK temperature on its quality index $Q_{D 4} \times x_{D 4}$

8. Policijos pareigūnų iškvietimo galimybè. Testas išspręstas remiantis $\mathrm{AB}$,Lietuvos geležinkeliai“ traukiniuose esama padètimi dèl policijos pareigūnų iškvietimo i traukini galimybès. KKVR dèmeniui skaičiuoti naudojama (2.64) formulè. Gaunama, $\operatorname{kad} x_{D 8}=0,50$.

Visų D grupès kriterijų kokybès lygmuo ir ji atitinkantis kintamojo dydžio $x_{D j}$ ivertis su realiais duomenimis pateiktas 4.5 lentelèje. Kokybès lygmuo ir ji atitinkantis kintamojo dydžio $x_{D j}$ ivertis su puikiais duomenimis yra 1, su vidutiniais duomenimis yra 0,5 , o su labai blogais duomenimis -0 .

Pagal (2.65) formulę apskaičiuojamas kriterijų, susietų su kelionès traukiniu saugumu, daugiakriteris rodiklis $K_{D}$ :

$$
\begin{aligned}
K_{D}= & 0,286 \cdot(0,1514 \cdot 0,971+0,0957 \cdot 0,50+0,1087 \cdot 0,50+0,1726 \cdot 1+ \\
& 0,1297 \cdot 1+0,0953 \cdot 1+0,1504 \cdot 1+0,0963 \cdot 0,50)=0,242 .
\end{aligned}
$$

Gaunama, kad kriterijų, susietų su kelionès traukiniu saugumu, grupès rodiklis $K_{D}=0,242$, t. y. D grupès kriterijų itaka KTK, išreikšta vienu parametru. 
4.5 lentelè. $\mathrm{D}$ grupès kriterijų kokybès lygmuo ir ji atitinkantis kintamojo dydžio $x_{D j}$ ivertis su realiais duomenimis

Table 4.5. Quality level of the criteria of group D and the respective value of the variable $x_{D j}$ based on real data

\begin{tabular}{|c|c|c|}
\hline $\begin{array}{l}\text { D grupès kriteriju kintamieji } \\
\text { dydžiai } x_{D j} \text { ir skaičiuojamosios } \\
\text { formules numeris }\end{array}$ & Dėmens reikšmė & $\begin{array}{l}\text { Apskaičiuotoji } \\
\quad \text { verte } x_{D j}\end{array}$ \\
\hline$x_{D 1}(2.57)$ & $\begin{array}{l}F E_{f}=2 ; F E_{\max }=2 ; O S P_{f}=2 \\
O S P_{\max }=2 ; I I A_{f}=2 ; I I A_{\max }=2 \\
U P S_{f}=2\left(1,2, \ldots, 6^{*}\right) ; U P S_{f}=0\left(7^{*}\right) \\
U P S_{\max }=2 ; G G I_{f}=2\left(1,2, \ldots, 7^{*}\right) \\
G G I_{\max }=2 ; V=7 ; F=5\end{array}$ & 0,971 \\
\hline$x_{D 2}(2.58)$ & $P M P_{f}=1 ; P M P_{\max }=2$ & 0,50 \\
\hline$x_{D 3}(2.59)$ & $G M P_{f}=1 ; G M P_{\max }=2$ & 0,50 \\
\hline$x_{D 4}(2.60)$ & $T_{f}=22 ; T_{\text {apl.oro }}=22$ & 1 \\
\hline$x_{D 5}(2.61)$ & $A I_{f}=2 ; A I_{\max }=2\left(1,2, \ldots, 7^{*}\right) ; V=7$ & 1 \\
\hline$x_{D 6}(2.62)$ & $V T T_{f}=4 ; V T T_{\max }=4\left(1,2, \ldots, 7^{*}\right) \quad V=7$ & 1 \\
\hline$x_{D 7}(2.63)$ & $\begin{array}{l}R S_{f}=2 ; R S_{\max }=2\left(1,2, \ldots, 7^{*}\right) \\
S K_{f}=4 ; S K_{\max }=4\left(1,2, \ldots, 7^{*}\right) \\
V=7 ; H=2\end{array}$ & 1 \\
\hline$x_{D 8}(2.64)$ & $P P I_{f}=1 ; P P I_{\max }=2$ & 0,50 \\
\hline
\end{tabular}

Pastaba: (c-ojo vagono*)

Tarptautinio traukinio daugiakriteris rodiklis $K$ apskaičiuojamas pagal formulę:

$$
K=K_{A}+K_{B}+K_{C}+K_{D},
$$

čia $K_{A}, K_{B}, K_{C}, K_{D}-\mathrm{A}, \mathrm{B}, \mathrm{C}$ ir D grupių kokybès kriterijų daugiakriteriai rodikliai.

Apskaičiuojamas (4.3 formule) tarptautinio traukinio Vilnius-Maskva daugiakriteris (daugiatikslis) rodiklis:

$$
K=K_{A}+K_{B}+K_{C}+K_{D}=0,133+0,115+0,151+0,242=0,641 .
$$

Gaunama, kad su realiais duomenimis tarptautinio traukinio VilniusMaskva ịvertis $K=0,641$, o su vidutinemis reikšmėmis jis lygus $K=0,497$ (L priedas), t. y. beveik 0,50 (labai maža paklaida). Kaip jau buvo minèta, KKVR kinta nuo 0 iki 1 . Galima teigti, kad kelionès traukiniu Vilnius-Maskva kokybė yra aukštesnè už vidutinę. 


\subsection{Kriterijų kitimo itakos kompleksiniam kokybès rodikliui tyrimas}

Naudojant Microsoft Exel programą buvo nustatytas KKVR įverčio $K$ jautrumas, rodantis vieno kintamojo pokyčio itaką $K$ vertei. Vieneto dalimi gauta, kiek argumento pokytis lemia funkcijos (rodiklio $K$ ) pokyti. Buvo apskaičiuotas $K_{0}$, kai vieno kriterijaus kintamasis dydis $x_{j}=0$, o likusių kriteriju $-x_{j}=0,50$ (pirmasis nulinis lygmuo), $K_{1}$, kai vieno kriterijaus kintamasis dydis $x_{j}=1$, o likusių kriteriju $-x_{j}=0,50$ (antrasis idealus lygmuo) ir $\Delta K=K_{1}-K_{0}$ (4.6 lentelè).

4.6 lentelė. Kelionės tarptautiniu traukiniu kompleksinio kokybės rodiklio $K$ matematinio modelio jautrumo skaičiavimo rezultatai

Table 4.6. The results obtained in calculating sensitivity of the mathematical model of the comprehensive quality index $K$, showing the quality of the trip by international train

\begin{tabular}{|c|c|c|c|c|c|}
\hline $\begin{array}{c}\text { Kriterijaus } \\
\text { eilès numeris }\end{array}$ & $\begin{array}{c}\text { Kriterijaus } \\
\text { żymuo }\end{array}$ & $\begin{array}{c}\text { Kriterijaus } \\
\text { kintamoji dalis }\end{array}$ & $K_{0}$, kai $x_{j}=0$ & $K_{1}$, kai $x_{j}=1$ & $\begin{array}{c}\Delta K= \\
K_{1}-K_{0}\end{array}$ \\
\hline 1 & 2 & 3 & 4 & 5 & 6 \\
\hline 1. & $\mathrm{~A}_{1}$ & $x_{A 1}$ & 0,492612042 & 0,501732042 & 0,00912 \\
\hline 2. & $\mathrm{~A}_{2}$ & $x_{A 2}$ & 0,485373098 & 0,508971098 & 0,023598 \\
\hline 3. & $\mathrm{~A}_{3}$ & $x_{A 3}$ & 0,493672298 & 0,500671898 & 0,0069996 \\
\hline 4. & $\mathrm{~A}_{4}$ & $x_{A 4}$ & 0,490765298 & 0,506485898 & 0,0157206 \\
\hline 5. & $\mathrm{~A}_{5}$ & $x_{A 5}$ & 0,490788098 & 0,503533298 & 0,0127452 \\
\hline 6. & $\mathrm{~A}_{6}$ & $x_{A 6}$ & 0,485806298 & 0,513519698 & 0,0277134 \\
\hline 7. & $\mathrm{~A}_{7}$ & $x_{A 7}$ & 0,485293298 & 0,509563898 & 0,0242706 \\
\hline 8. & $\mathrm{~A}_{8}$ & $x_{A 8}$ & 0,487903898 & 0,503829698 & 0,0159258 \\
\hline 9. & $\mathrm{~A}_{9}$ & $x_{A 9}$ & 0,490058498 & 0,502131098 & 0,0120726 \\
\hline 10. & $\mathrm{~A}_{10}$ & $x_{A 10}$ & 0,489089498 & 0,506223698 & 0,0171342 \\
\hline 11. & $\mathrm{~A}_{11}$ & $x_{A 11}$ & 0,493239098 & 0,496955498 & 0,0037164 \\
\hline 12. & $\mathrm{~A}_{12}$ & $x_{A 12}$ & 0,493068098 & 0,501447098 & 0,008379 \\
\hline 13. & $\mathrm{~A}_{13}$ & $x_{A 13}$ & 0,492042098 & 0,503328098 & 0,011286 \\
\hline 14. & $\mathrm{~A}_{14}$ & $x_{A 14}$ & 0,487801298 & 0,510783698 & 0,0229824 \\
\hline 15. & $\mathrm{~A}_{15}$ & $x_{A 15}$ & 0,493079498 & 0,495986498 & 0,002907 \\
\hline 16. & $\mathrm{~A}_{16}$ & $x_{A 16}$ & 0,492019298 & 0,503385098 & 0,0113658 \\
\hline 17. & $\mathrm{~B}_{1}$ & $x_{B 1}$ & 0,484951298 & 0,509392898 & 0,0244416 \\
\hline 18. & $\mathrm{~B}_{2}$ & $x_{B 2}$ & 0,493831898 & 0,500512298 & 0,0066804 \\
\hline 19. & $\mathrm{~B}_{3}$ & $x_{B 3}$ & 0,491369498 & 0,502974698 & 0,0116052 \\
\hline 20. & $\mathrm{~B}_{4}$ & $x_{B 4}$ & 0,493752098 & 0,500592098 & 0,00684 \\
\hline 21. & $\mathrm{~B}_{5}$ & $x_{B 5}$ & 0,494025698 & 0,500318498 & 0,0062928 \\
\hline 22. & $\mathrm{~B}_{6}$ & $x_{B 6}$ & 0,492600698 & 0,501743498 & 0,0091428 \\
\hline 23. & $\mathrm{~B}_{7}$ & $x_{B 7}$ & 0,490332098 & 0,504012098 & 0,01368 \\
\hline 24. & $\mathrm{~B}_{8}$ & $x_{B 8}$ & 0,494652698 & 0,499691498 & 0,0050388 \\
\hline & & & & & \\
\hline & & & & & \\
\hline & & & & &
\end{tabular}


4.6 lentelès pabaiga

\begin{tabular}{|c|c|c|c|c|c|}
\hline 1 & 2 & 3 & 4 & 5 & 6 \\
\hline 25. & $\mathrm{~B}_{9}$ & $x_{B 9}$ & 0,494675498 & 0,499668698 & 0,0049932 \\
\hline 26. & $\mathrm{~B}_{10}$ & $x_{B 10}$ & 0,491848298 & 0,502495898 & 0,0106476 \\
\hline 27. & $\mathrm{~B}_{11}$ & $x_{B 11}$ & 0,495120098 & 0,499224098 & 0,004104 \\
\hline 28. & $\mathrm{~B}_{12}$ & $x_{B 12}$ & 0,494185298 & 0,500158898 & 0,0059736 \\
\hline 29. & $\mathrm{~B}_{13}$ & $x_{B 13}$ & 0,486934898 & 0,507409298 & 0,0204744 \\
\hline 30. & $\mathrm{~B}_{14}$ & $x_{B 14}$ & 0,490480298 & 0,503863898 & 0,0133836 \\
\hline 31. & $\mathrm{~B}_{15}$ & $x_{B 15}$ & 0,485430098 & 0,508914098 & 0,023484 \\
\hline 32. & $\mathrm{~B}_{16}$ & $x_{B 16}$ & 0,490788098 & 0,503556098 & 0,012768 \\
\hline 33. & $\mathrm{~B}_{17}$ & $x_{B 17}$ & 0,488120498 & 0,506223698 & 0,0181032 \\
\hline 34. & $\mathrm{~B}_{18}$ & $x_{B 18}$ & 0,491392298 & 0,502951898 & 0,0115596 \\
\hline 35. & $\mathrm{~B}_{19}$ & $x_{B 19}$ & 0,487755698 & 0,506588498 & 0,0188328 \\
\hline 36. & $\mathrm{C}_{1}$ & $x_{C 1}$ & 0,455143898 & 0,539200298 & 0,0840564 \\
\hline 37. & $\mathrm{C}_{2}$ & $x_{C 2}$ & 0,485524056 & 0,510859656 & 0,0253356 \\
\hline 38. & $\mathrm{C}_{3}$ & $x_{C 3}$ & 0,490064198 & 0,504279998 & 0,0142158 \\
\hline 39. & $\mathrm{C}_{4}$ & $x_{C 4}$ & 0,477602798 & 0,516741398 & 0,0391386 \\
\hline 40. & $\mathrm{C}_{5}$ & $x_{C 5}$ & 0,460484498 & 0,533859698 & 0,0733752 \\
\hline 41. & $\mathrm{C}_{6}$ & $x_{C 6}$ & 0,486219998 & 0,508124198 & 0,0219042 \\
\hline 42. & $\mathrm{D}_{1}$ & $x_{D 1}$ & 0,475521898 & 0,518822298 & 0,0433004 \\
\hline 43. & $\mathrm{D}_{2}$ & $x_{D 2}$ & 0,483486998 & 0,510857198 & 0,0273702 \\
\hline 44. & $\mathrm{D}_{3}$ & $x_{D 3}$ & 0,481627998 & 0,512716198 & 0,0310882 \\
\hline 45. & $\mathrm{D}_{4}$ & $x_{D 4}$ & 0,472490298 & 0,521853898 & 0,0493636 \\
\hline 46. & $\mathrm{D}_{5}$ & $x_{D 5}$ & 0,478624998 & 0,515719198 & 0,0370942 \\
\hline 47. & $\mathrm{D}_{6}$ & $x_{D 6}$ & 0,483544198 & 0,510799998 & 0,0272558 \\
\hline 48. & $\mathrm{D}_{7}$ & $x_{D 7}$ & 0,475664898 & 0,518679298 & 0,0430144 \\
\hline 49. & $\mathrm{D}_{8}$ & $x_{D 8}$ & 0,483401198 & 0,510942998 & 0,0275418 \\
\hline
\end{tabular}

Iš stulpelinès diagramos (4.15a pav.) matyti, kad didžiausia $K_{1}=0,539$ vertè yra tada, kai C1 kriterijaus kintamoji dalis $x_{C 1}=1$, o mažiausia $K_{1}=0,496$, kai A15 kriterijaus kintamoji dalis $x_{A 15}=1$.

Iš stulpelinès diagramos (4.15b pav.) matyti, kad didžiausia $K_{0}=0,495$ vertè yra tada, kai B8, B9 ir B11 kriteriju kintamosios dalys $x_{B 8}=0, x_{B 9}=0$ ir $x_{B 11}=0$, o mažiausia $K_{0}=0,455$ vertè yra tada, kai C1 kriterijaus kintamoji dalis $x_{C 1}=0$.

Atskiru kriterijų itaka KKVR $K$ nustatyta iš $\Delta K$. Kuo pokytis $\Delta K$ yra didesnis, tuo daugiau ittakos KKVR įverčiui $K$ turi analizuojamas kriterijus. Didžiausią itaką (4.16 pav.) $K$ daro $\mathrm{C}$ ir $\mathrm{D}$ grupių kriterijai: $\mathrm{C} 1(\Delta K=0,084), \mathrm{C} 5$ $(\Delta K=0,073), \mathrm{C} 4(\Delta K=0,039)$ ir $\mathrm{D} 4(\Delta K=0,049)$, taip pat D1 ir D7 $(\Delta K=0,043), \mathrm{D} 5(\Delta K=0,037)$, nes jų pokytis yra didžiausias. 


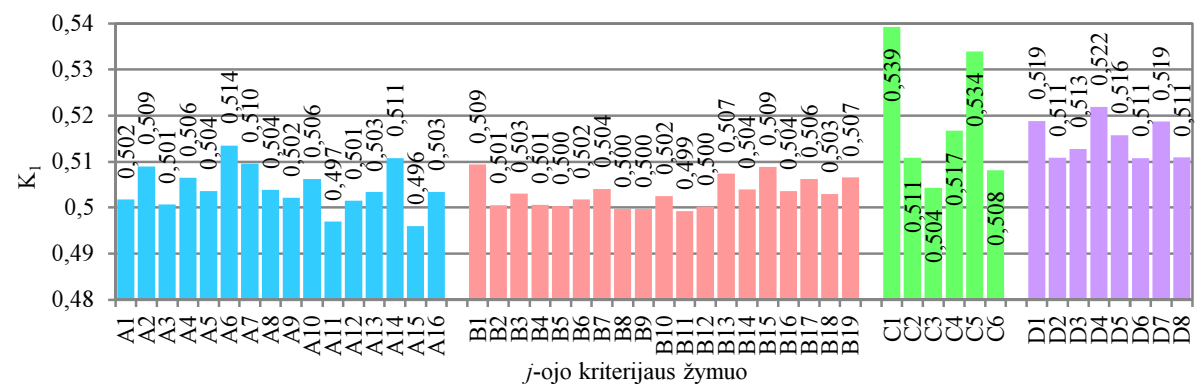

a)

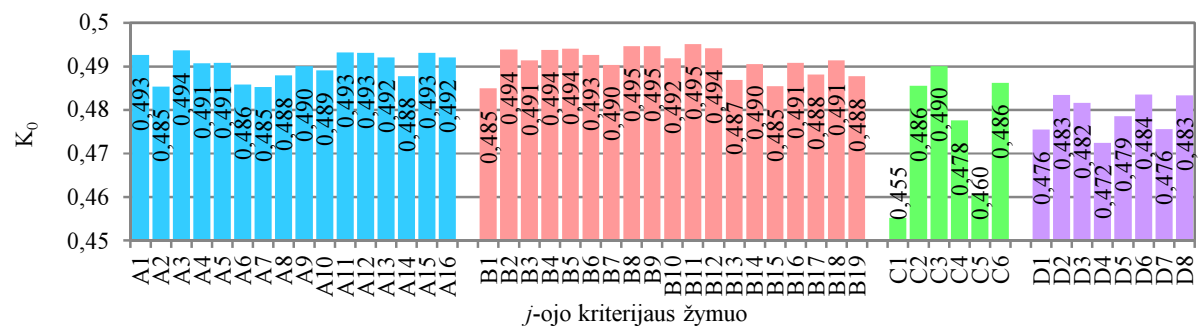

b)

4.15 pav. Keleivių vežimo tarptautiniu traukiniu kompleksinio kokybès rodiklio $K$ matematinio modelio jautrumo tikrinimo rezultatai: a $-K_{1}$ verté, kai $j$-ojo kriterijaus kintamoji dalis $x_{j}=1 ; \mathrm{b}-K_{0}$ verte, kai $j$-ojo kriterijaus kintamoji dalis $x_{j}=0$

Fig. 4.15. Testing the results obtained in calculating sensitivity of the mathematical model of the comprehensive quality index $K$, showing the quality of the trip by international train: a is the value of $K_{1}$, when the variable part of the $j$-th criterion is $x_{j}=1$; b is the value of $K_{0}$, when the variable part of the $j$-th criterion is $x_{j}=0$

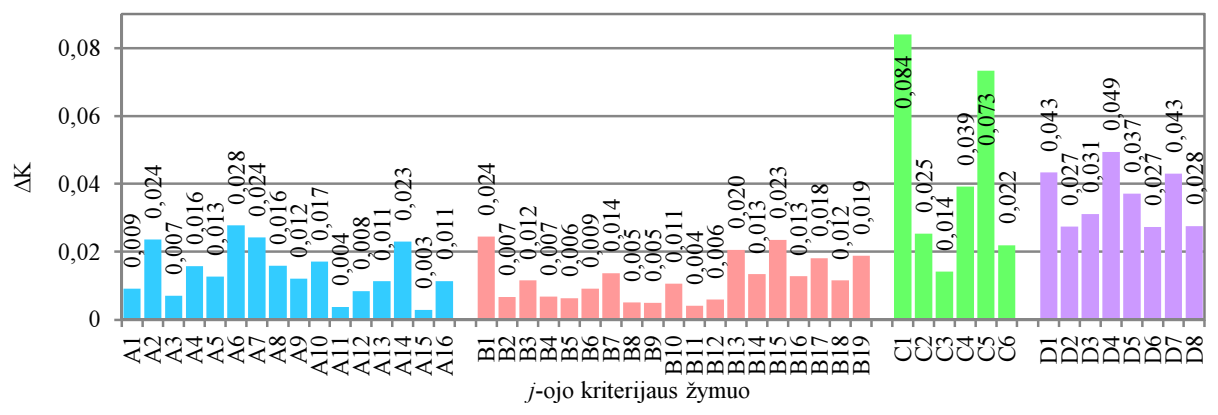

4.16 pav. $K$ vertes pokytis $\Delta K=K_{1}-K_{0}$

Fig. 4.16. The change $\Delta K=K_{1}-K_{0}$ of the value $K$ 
Mažiausią itaką daro A ir B grupių kriterijai: A15 $(\Delta K=0,003)$, A11 $(\Delta K=0,004), \mathrm{A} 3(\Delta K=0,007)$ ir $\mathrm{B} 11(\Delta K=0,004), \mathrm{B} 8, \mathrm{~B} 9(\Delta K=0,005), \mathrm{B} 5$, $\mathrm{B} 12(\Delta K=0,006)$, nes ju pokytis yra mažiausias.

Santykinis skirtumas tarp didžiausios ir mažiausios kriterijaus įtakos didumo yra lygus $96,4 \%$.

\subsection{Praktinis pritaikymas}

Sukurtas ir pasiūlytas daugiakriteris kompleksinio vertinimo modelis gali būti sèkmingai naudojamas siekiant išanalizuoti ir tarpusavyje palyginti tarptautinio susisiekimo traukinių atskirų maršrutų kokybę. Atlikus daugiakriteri vertinimą pagal moksliniame darbe pateiktą metodika, galima apskaičiuoti keleivių vežimo kokybès kriterijų faktiškąsias vertes ir pagal jas nustatyti, kurių iš tiriamų kokybės kriterijų itaka KTK yra didžiausia ir kurių mažiausia. Kelionès traukiniu kokybei pagerinti imtis priemonių, kurių visuma leistų priartèti prie paties geriausio rezultato.

Vertinimo metodika gali būti pritaikyta tarptautinių traukinių sąstatams, suformuotiems iš skirtingų keleivinių vagonu̧, esant skirtingoms teikiamoms paslaugoms, kainoms. Ši vertinimo metodika gali būti lengvai pritaikoma ir vietinio susisiekimo traukiniuose: nevertinant kokybès kriterijų, būdingų tik tarptautinio susisiekimo maršrutams, itakos KTK, pvz., vizų kaina, muitinès ir pasienio pareigūnų kompetencija ir kt. Atkritus kriterijui, pvz., tarp šalių panaikinama vizų sistema, atmestojo kriterijaus vidutinis svorio koeficientas dalijamas proporcingai likusių grupejje kriterijų svoriams ir gauti dalmenys pridedami prie atitinkamų kriterijų. Didžiausiam (svarbiausiam) kriterijui pridedama didžiausia panaikinto kriterijaus svorio dalis. Likusių kriterijų svorio vidurkių suma būna lygi vienetui.

Daugiakriteriam vieno tarptautinio traukinio vertinimui atlikti reikia žinoti sąstate esančių vagonų konstrukciją, kategorijas, teikiamų paslaugų spektrą, bilietų kainas, aptarnaujančio personalo darbuotojų gebejjimus ir kt.

Apskaičiuotas tarptautinio traukinio daugiakriteris rodiklis yra išreikštas vienu parametru, todèl lengvai palyginamas su kito traukinio rodikliu.

Pasiūlyto daugiatikslio kompleksinio vertinimo modelio rezultatai gali būti sèkmingai naudojami gražia tradicija $\mathrm{AB}$ „Lietuvos geležinkeliai“ tapusia nominacijų „Geriausia keleivinio traukinio brigada“ teikime. Galètų būti nominacija „Geriausia kelione traukiniu“ arba „Geriausias traukinio maršrutas“. 


\subsection{Ketvirtojo skyriaus išvados}

1. Sudarytame originaliame adityviniame matematiniame modelyje apskaičiuojamos kiekvieno iš 49 kriteriju vertès, sudarytos iš kriterijaus normalizuoto svorio koeficiento, padauginto iš kintamosios jo dalies, rodančios kriterijaus kintamosios dalies atitiktị norminèms, kritinèms, maksimalioms leidžiamoms arba geriausioms vertėms. Lyginant kriterijaus kintamos dalies faktiškąsias vertes su norminėmis, kritinėmis, maksimaliomis leidžiamomis arba geriausiomis vertèmis, apskaičiuojamas dydis, rodantis, kiek kelionès traukiniu kriterijus artimas geriausiam siekiamam lygmeniui (kai jo verte lygi 1), vidutiniam lygmeniui (kai jo vertè lygi 0,5 ) ir blogiausiam lygmeniui (kai jo verte lygi 0 ).

2. Kelionès traukiniu kokybès daugiakriteris vertinimo modelis leidžia objektyviai vienu parametru išreikšti keleivių vežimo kokybę traukinyje. Apskaičiuotos atskirų rodiklių: $K_{A}=0,133, K_{B}=0,115, K_{C}=0,151$ ir $K_{D}=0,242$ vertès, naudojant realius parametrų dydžius, leidžia teigti, kad matematinis modelis yra teisingas ir naudotinas praktikoje.

3. B grupès TKVGKK daugiakriteris rodiklis yra mažiausias $K_{B}=0,115$, todèl galima teigti, kad B grupès kokybès kriteriju įtaka KTK yra mažiausia.

4. Didžiausia yra D TKVGKK grupès daugiakriterio rodiklio reikšmè $K_{D}=0,242$, todèl D grupès kokybès kriterijų itaka KTK yra didžiausia.

5. Vienų kriterijų faktiškosios vertès yra norminès, kitu - nenorminès. Jeigu nors vienas normuotasis kriterijus yra labai blogas arba neatitinka leidžiamų verčių, tai nors kiti kriterijai yra geri arba labai geri, kelionè traukiniu negali būti vertinama pozityviai. Nenormuotieji kriterijai gali būti ịvairūs, nes jie kelionei traukiniu neigiamų pasekmių nesukelia.

6. Apskaičiuotas tarptautinio traukinio Vilnius-Maskva daugiakriteris kokybès rodiklis $K=0,641$.

7. Atskirų kriterijų itaką KKVR įverčiui $K$ galima nustatyti pagal pokyti $\Delta K=K_{1}-K_{0}$. Nustatyta, kad didžiausią itaką KKVR įverčiui $K$ daro C ir D grupių kriterijai: C1 $(\Delta K=0,084), \mathrm{C} 5(\Delta K=0,073), \mathrm{C} 4(\Delta K=0,039)$ ir $\mathrm{D} 4$ $(\Delta K=0,049), \mathrm{D} 1, \mathrm{D} 7(\Delta K=0,043), \mathrm{D} 5(\Delta K=0,037)$, nes jų pokytis yra didžiausias.

8. Mažiausią itaką rodikliui $K$ daro A ir B grupių kriterijai: A15 $(\Delta K=0,003), \mathrm{A} 11(\Delta K=0,004), \mathrm{A} 3(\Delta K=0,007)$ ir B11 $(\Delta K=0,004), \mathrm{B} 8, \mathrm{~B} 9$ $(\Delta K=0,005), \mathrm{B} 5, \mathrm{~B} 12(\Delta K=0,006)$, nes jų pokytis yra mažiausias.

Tarptautinio keleivių vežimo geležinkeliais moksliniais tyrimais pagrisstos priemonès (rekomendacijos) KTK gerinti:

1. Taikant AHP metodą buvo nustatyta, kad iš A grupès kriterijų keleiviams svarbiausi yra kriterijus A2 $=0,1334$ (traukinio greitis (važiavimo truk- 
mè), A7 $=0,1218$ (reikiama vagono vidaus temperatūra) ir A6 =0,1071 (vèdinimo, oro kondicionavimo, apšvietimo irangos veikimas). Traukiniu greičiui didinti, važiavimo trukmei mažinti yra būtina gerinti geležinkelio kelių būklę, kad jų KKI būtų nuo 0 iki 20 (labai geras). Mažinti stovèjimo laiką pasienio stotyse. Reikiamai vagono vidaus temperatūrai užtikrinti (ypač vasaros laikotarpiu) būtina modernizuoti arba pirkti naujus riedmenis, kuriuose būtų vėdinimo, oro kondicionavimo sistemos.

2. Iš $\mathrm{B}$ grupès kriterijų keleiviams svarbiausi yra kriterijus $\mathrm{B} 1=0,1283$ (traukinių išvykimas ir atvykimas laiku), B13 = 0,1037 (keleivių bagažo ir daiktų apsauga) ir B15 = 0,074 (vizos įsigijimo pasienio punkte galimybè). Traukinių važiavimo grafikai šiuo metu yra griežtai kontroliuojami. Keleivių bagažui ir daiktams skirtos vietos galètų būti rakinamos arba vagonuose irengtos stebejjimo kameros. Būtina pasienio punktuose numatyti vizos įsigijimo galimybę, kad esant būtinybei (neturi vizos, pasibaigęs jos galiojimo laikas), keleivis galètų gauti vizą ir tęsti kelionę tuo pačiu traukiniu.

3. Iš $\mathrm{C}$ grupès kriterijų keleiviams svarbiausi yra kriterijus $\mathrm{C} 1=0,3659$ (bilieto kaina), $\mathrm{C} 5=0,2536$ (vizų kaina) ir $\mathrm{C} 4=0,1385$ (užsienio medicininių išlaidų draudimo kaina). Norint pritraukti keleivius keliauti geležinkelių transportu, būtina mažinti vizų kainas. Dažnai traukiniu keliaujantiems keleiviams taikyti lojalumo programas.

4. Iš D grupès kriterijų keleiviams svarbiausi yra kriterijus D7 $=0,1449$ (rankinio stabdžio būklè ir veikimas, stabdų būklè), D1 =0,1361 (gaisro gesinimo priemonių buvimas ir būklè) ir D2 $=0,1285$ (pirmos medicinos pagalbos priemonių buvimas). Kelionès saugumui užtikrinti riedmenys privalo būti techniškai tvarkingi, aprūpinti visomis privalomomis priešgaisrinès saugos priemonèmis. Būtina traukiniuose didinti pirmos medicinos pagalbos priemonių skaičių, kad jų užtektų ekstremaliais atvejais, pvz., ỉvykus teroristiniam aktui ir kt.

Kai kurios priemonès, pavyzdžiui, vizos kaina, vizos isigijimo pasienio punkte galimybẻ yra politinio pobūdžio, todèl sprendimai dèl jų turètų būti priimami valstybiniu lygmeniu. Dauguma keleivių vežimo geležinkeliais kokybès gerinimo priemonių pareikalaus daug investicijų, kurias būtina surinkti iš visų galimų šaltinių.

Praktine autorès patirtimi pagrįstos priemonès (rekomendacijos) KTK gerinti:

1. Vagonuose, kuriuose yra įrengtos ausiniu prieigos, keleiviams skirti ausines.

2. Platinti ivvairesnę spaudą traukinyje (pageidautina daugiau nemokamos spaudos). 
3. Numatyti traukinio viršininko rezervines vietas paprastuosiuose miegamuosiuose vagonuose.

4. Dažniau (bent kartą per pusmeti) keisti muzikinius ir kino filmų įašus, leidžiamus traukinyje.

5. Skirti padavejją restorano vagone.

6. Sudaryti sutartị su drabužių valymo imone, kad darbuotojų uniforminè apranga būtų valoma su nuolaida. Siūti traukinį aptarnaujantiems darbuotojams žieminę ir vasarinę uniforminę aprangą. Žiemai skirti marškinèliai galètu būti kitos spalvos (ne balti). Aprūpinti traukini aptarnaujančius darbuotojus darbo avalyne.

7. Dažniau (bent kartą per metus) organizuoti i̇vairius darbuotojų mokymus: techninius, etikos, užsienio kalbos, pirmosios medicinos pagalbos teikimo. Tikslinga rengti dalykinius, siauros srities darbuotojų mokymus, skirtus suteikti žinių ir ugdyti igūdžius konkrečiai praktinei problemai, su kuria darbuotojai susiduria kasdieninèje veikloje, spręsti. Būtina atlikti ir organizacijos vidinius tyrimus: mikroklimato, darbuotojų pasitenkinimo darbu, mokymo poreikių.

8. Keisti traukinị aptarnaujančių darbuotojų atestavimo tvarką. Būtina tobulinti atestuojamojo darbuotojo charakteristikos lapa ( $\mathrm{AB}$,Lietuvos geležinkeliai“ darbuotojo atestavimo nuostatų 1 priedas). Jame galètų būti pateikti konkretūs darbuotojo darbinès veiklos rezultatai, pavyzdžiui, traukinio viršininko asmeniniai: už bilietų traukinyje pardavimą ir viso jo vadovaujamo kolektyvo: už konditerijos gaminiu, spaudos ir kt. realizavimą traukinyje. Atestacija neturètų būti formali procedūra, kurios reali nauda imonei yra labai abejotina. Vien formaliomis priemonèmis pagristas vertinimas darbuotojui neturi jokios išliekamosios vertès arba neretai yra tik vadovybès kontrolès procedūra, kurią reikia kaip nors ,ištverti“. Atestacijos tikslas - skatinti darbuotoją siekti veiklos sẻkmès ir sukurti papildomų prielaidų jo darbo našumui didinti.

9. Dažniau (bent kartą per pusmeti) rengti traukiniuose keleivių apklausas.

10. Dažniau (bent kartą per pusmeti) keisti restorano vagone parduodamų patiekalų asortimentą. Didinti vegetariškų patiekalų pasirinkimą.

11. Važiuojantiems per didžiąsias metų šventes (Kalèdas, Naujuosius metus) keleiviams, ypač vaikams, suorganizuoti sveikinimo programą (pasitelkus aptarnaujantị personala), iteikti suvenyrų su geležinkelio logotipais.

12. Traukiniui aptarnauti skirti kvalifikuotus, mokančius mažiausiai vieną užsienio kalbą vagonų palydovus. Riboti vagonų palydovų amžių iki $45 \mathrm{~m}$. 


\section{Bendrosios išvados}

1. Norminiuose dokumentuose vertinami atskiri parametrai, tačiau nèra kompleksinio daugiakriterio vertinimo metodikos. Atlikus mokslinès literatūros, nagrinèjančios geležinkelio infrastruktūrą, riedmenis ir keleivių vežimo geležinkeliais procesa, analizę nustatyta, kad atliekama daug tyrimų šioms sudėtinėms geležinkelių transporto dalims vertinti ir gerinti, tačiau kelionès traukiniu procesas beveik nenagrinètas.

2. Kiekvienos iš trijų kategorijų apklaustujų (respondentų ir ekspertų) atsakymu i kiekvienos anketos klausimus duomenų (kriterijų) svarbumui (svoriui) nustatyti pritaikytas AHP metodas. Nustatyta, kad keleivių ir traukini aptarnaujančio personalo nuomonès dèl visų grupių kriterijų svarbos yra suderintos. Administracijos darbuotojų nuomonès dèl D grupès kriterijų svarbos yra nesuderintos.

3. Nustatyta A, B, C ir D kriterijų grupių svarba. Keleivių nuomonès yra nesuderintos: empirinis konkordancijos koeficientas 0,038 , o mažiausia verte 0,180 . Traukini aptarnaujančio personalo ir administracijos darbuotojų nuomonès yra suderintos.

4. Sukurtas daugiakriteris vertinimo modelis, leidžiantis vienu parametru vertinti ir palyginti atskirų tarptautinio susisiekimo maršrutų kokybę. Jo adekvatumas (korektiškumas) patikrintas ir patvirtintas remiantis atliktų eksperi- 
mentų ir skaičiavimų duomenimis tiriant kelionès tarptautiniu traukiniu Vilnius-Maskva kokybę.

5. Nustatyta kriterijų kitimo įtaka KKVR, rodanti, kad didžiausią įtaką K daro C ir D grupių kriterijai: bilieto kaina (pokytis 0,084 ), vizų kaina (pokytis 0,073), ašiděžiu perkaičio signalizacijos veikimas (pokytis 0,049), gaisro gesinimo priemonių buvimas ir būklè, taip pat rankinio stabdžio būkle ir veikimas, stabdų būklè (pokytis 0,043 ). Jų pokytis yra didžiausias. Mažiausią įtaką kompleksiniam kokybès vertinimo rodikliui daro A ir B grupių kriterijai: palydovo skubaus iškvietimo i kupé galimybė (pokytis 0,003 ), specialios kupe dviračiams vežti (pokytis 0,004 ), prekyba suvenyrais traukinyje (pokytis 0,004 ), vietų restorano vagone rezervavimo galimybe ir taksi iškvietimo paslauga (pokytis 0,005 ). Jų pokytis yra mažiausias.

6. Kuo didesnis skirtumas, kurị rodo kompleksinio kokybès vertinimo rodiklio vertès pokytis, tuo kriterijaus verte, keičiama nuo blogiausios (0 lygmuo) iki geriausios (1 lygmuo), rodo didesni modelio jautrumą $K$ rodikliui. Tai reiškia, kad gerinant ši kriterijų, galima gauti didžiausią keleivių vežimo tarptautiniu traukiniu kokybės pagerèjima, bet tai nereiškia, kad jam gerinti reikia mažiausių investicijų. Investicijų dydį, siekiant maksimalios kriterijaus kintamosios dalies, reikètų nustatyti papildomais ekonominiais tyrimais. 


\section{Literatūra ir šaltiniai}

Abdelrahman, M.; Zayed, T; Elyamany, A. 2008. Best-value model based on project cpecification characteristics, Journal of Construction Engineering and Management 134(3): 179-188.

Adamko, N.; Klima, V. 2008. Optimisation of railway terminal design and operations using Villon generic simulation model, Transport 23(4): 335-340.

Aghdaie, M. H.; Zolfani, S. H.; Zavadskas, E. K. 2012. Prioritizing constructing projects of municipalities based on AHP and COPRAS-G: a case study about footbridges in tran, The Baltic Journal of Road and Brigde Engineering 7(2): 145-153. doi:10.3846/bjrbe. 2012.20.

Akgüngör, A. P.; Demirel, A. 2008. Investigating urban traffic based noise pollution in the city of Kirikkale, Turkey, Transport 23(3): 273-278.

Anastasopoulos, I.; Alfi, S.; Gazetas, G.; ASCE, M.; Bruni, S.; Van Leuven, A. 2009a. Numerical and experimental assessment of advanced concepts to reduce noise and vibration on urban railway turnouts, Journal of Transportation Engineering 135(5): 279-287. doi:10.1061/(ASCE)TE.1943-5436.0000007.

Baublys, A. 2009. Principles for modeling technological processes in transport terminal, Transport 24(1): 5-13.

Bazaras, Ž.; Dundulis, R. 1996. Vagonai ir konteineriai. Kaunas: Technologija. 140 p. ISBN 9986-13-439-0. 
Bazaras, Ž. 2006. Internal noise modelling problems of transport power equipment, Transport 21(1): 19-24.

Bazaras, Ž.; Sapragonas, J.; Vasauskas, V. 2008. Evaluation of the strength anisotropy for railway wheels, Journal of Vibroengineering 10(3): 316-324.

Bazaras, Ž.; Somov, D. 2011. The restoration of physical and mechanical properties of wheel rim metal, Transport 26 (3): 240-247. doi:10.3846/1648-4142.2011.622132.

Brauers, W. K. M.; Zavadskas, E. K.; Peldschus, F.; Turskis, Z. 2008. Multi-objective decision-making for road design, Transport 23(3): 183-193. doi:10.3846/16484142.2008.23.183-193.

Bruni, S.; Anastasopoulos, I.; Alfi, S.; Van Leuven, A.; Apostolou, M.; M. ASCE, G. G. 2009b. Train-induced vibrations on urban metro and tram turnouts, Journal of Transportation Engineering 135(5):397-405. doi: 10.1061/(ASCE)TE.1943-5436.0000008.

Bureika, G. 2008a. A mathematical model of train continuous motion uphill, Transport 23(2): 135-137.

Bureika, G. 2011. Multicriteria evaluation of operational effectiveness of freight diesel locomotives on Lithuanian railways, Transport 26 (1): 61-68. doi:10.3846/16484142.2011.561947.

Bureika, G.; Mikaliūnas, Š. 2008b. Research on the compatibility of the calculation methods of rolling - stock brakes, Transport 23(4): 351-355.

Burrow, M. P. N.; Naito, S.; Evdorides, H. T. 2009. Network-level railway track maintenance management model, Transportation Research Record 2117: 66-76. doi:10.3141/2117-09.

Butkevičius, J.; Jaržemskis, A. 2000. Geležinkeliu transporto plètros Europoje perspektyvos. Transportas 15(16): 272-278.

Butkevičius, J. 2007. Development of passenger transportation by railroad from Lithuania to European states, Transport 22(2): 73-79.

Butkevičius, J. 2008. Lietuvos ịstojimo į Europos Sajungą poveikis šalies transporto sistemai ir transporto sistemos plètra. Vilnius: Technika. 251 p. ISBN 978-9955-28-215-0.

Butkevičius, J. 2009. The strategy of passenger transportation by national railway transport: the implementation of public service obligations, Transport 24(2): 180-186. doi: 10.3846/1648-4142.2009.24.180-186.

Calvo, F. J.; J. de Oña. 2005. Opening of the European railroad network. A lost opportunity for European unification, Transportation Research Record 1916: 8-19.

Calvo, F. J.; J. de Oña; Nash, A. 2007a. Proposed infrastructure pricing methodology for mixed-use rail networks. Transportation Research Record: 1995: 9-16. doi:10.3141/1995-02.

Campbell, J. M.; Smith, S. D.; Forde, M. Ch.; Ladd, R. D.; 2007. Identifying hazards in transportation construction and maintenance tasks. Case-based reasoning approach using railroad data, Transportation Research Record: 1995: 69-75. doi:10.3141/1995-09. 
Cheng, M-Y.; Su, Ch-W.; Tsai, M-H.; Lin, K-S. 2012. Data preprocessing for artificial neural network applications in prioritizing railroad projects - a practical experience in Taiwan, Journal of Civil Engineering and Management 18(4): 483-494. doi:10.3846/13923730.2012.699914.

Chua, D. K. H.; Li, D. 2000. Key factors in bid reasoning model, Journal of construction Engineering and Management 126(5): 349-537.

Clever, R.; Hansen, M. M. 2008. Interaction of air and high-speed rail in Japan, Transportation Research Record: Journal of the Transportation Research Board 2043: 1-12. doi:10.3141/2043-01.

Coccia, S.; Bartoli, I.; Salamone, S.; Philips, R.; Lanza di Scalea, F.; Fateh, M.; Carr, G. 2009. Noncontact ultrasonic guided wave detection of rail defects, Transportation Research Record 2117: 77-84. doi:10.3141/2117-10.

Čekanavičius, V.; Murauskas, G. 2004. Statistika ir jos taikymai. II. Vilnius: TEV. 271 p.

Česnauskis, M. 2007. Model for probabilistic assessment of oil outflow event caused by tanker accident, Transport 22(3): 187-194.

Dailydka, S.; Lingaitis, L. P.; Myamlin, S.; Prichodko, V. 2008. Modelling the interaction between railway wheel and rail, Transport 23(3): 236-239.

Dailydka, S. 2010. Choosing raiway vehicles for carrying passengers, Transport 25(1):11-16. doi:10.3846/transport. 2010.02.

Daunys, M.; Putnaitè, D.; Bazaras, Ž. 2009. Principles for modelling technological processes investigation into the strength and durability of automatic coupler SA-3 in railway carriages, Transport 24(2): 83-92. doi:10.3846/1648-4142.2009.24.83-92.

Dell'Orco, M.; Ottomanelli, M.; Caggiani, L.; Sassanelli, D. 2008. New decision support system for optimization of rail track maintenance planning based on adaptive neurofuzzy inference system, Transportation Research Record 2043: 49-54. doi:10.3141/2043-06.

Dingler, M. H.; Lai, Y.-Ch. [R].; Barkan, Ch. P. L. 2009. Impact of train type heterogeneity on single-track railway capacity, Transportation Research Record 2117: 41-49. doi: $10.3141 / 2117-06$.

Dinh, V. N.; Kim, K. D.; Warnitchai, P. 2009. Dynamic analysis of three-dimensional bridge-high-speed train interactions using a wheel-rail contact model, Engineering Structures 31 (2009): 3090-3106. doi:10.1016/j.engstruct.2009.08.015.

Dirnberger, J. R.; Barkan, Ch. P. L. 2007. Lean railroading for improving railroad classification terminal performance, Transportation Research Record 1995: 52-61. doi:10.3141/1995-07.

Dzemydienè, D.; Dzindzalieta, R. 2010. Development of architecture of embedded decision support systems for risk evaluation of transportation of dangerous goods, Technological and Economic Development of Economy 16(4): 654-671. doi: 10.3846/tede. 2010.40 . 
Farhan, J; Fwa, T. F. 2009. Pavement maintenance prioritization using Analytic Hierarchy Process, Transportation Research Record 2093: 12-24. doi:10.3141/2093-02.

Fitzmaurice, M. 2005. Use of wireless local area networks in rail and urban transit environments. Transportation Research Record 1916: 42-46.

Gailienè, I.; Podagèlis, I.; Slepakovas, O. 2008. Research on the lifetime of the switch and assumptions of increasing it, Transport 23(2): 150-155.

Gašparík, J.; Zitrický, V. 2010. A new approach to estimating the occupation time of the railway infrastructure, Transport 25(4): 387-393. doi:10.3846/transport.2010.48.

Gelumbickas, G. ; Vaičiūnas, G. 2011. Analysis of passenger rolling stock foults and its statistics in Lithuania, Transport 26 (3):315-319. doi:10.3846/1648-4142.2011.618190.

Ginevičius, R.; Podvezko, V.; Andruškevičius, A. 2004. Statybos sistemų technologiškumo nustatymas AHP metodu [Determining of technological effectiveness of building systems by AHP method], Technological and Economic Development of Economy 10(4): $135-141$.

Ginevičius, R.; Podvezko, V. 2008. Multicriteria evaluation of Lithuanian banks from the perspective of their reliability for clients, Journal of Business Economics and Management 9(4): 257-267.

Gould, G.; Niemeier, D. 2009. Review of regional locomotive emission modeling and the constrains posed by activity data, Transportation Research Record 2117: 24-32. doi: $10.3141 / 2117-04$.

Guirao, B.; Menéndez, J. M.; Rivas, A. 2005. Bimodal use of high-speed rail lines, Transportation Research Record 1916: 1-7.

Hagiwara, Y.; Ishikawa, S.; Furuya, M. 2007. Innovative lightweight technologies using power electronics on shinkansen high-speed electric multiple units, Transportation Research Record 1995: 43-51. doi:10.3141/1995-06.

Hall, L. 2003. Simulations and analyses of train-induced ground vibrations in finite element models, Soil Dynamics and Earthquake Engineering 23 (2003): 403-413. doi: 10.1016/SO267-7261(02)00209-9.

Hamilton, B. A.; Edwards \& Kelcey, J. 2009. Shared use of railroad infrastructure with noncompliant public transit rail vehicles: A practitioner's guide. Transit cooperative research program (TCRP). Report 130. National Research Council, Washington, D. C.: National Academy Press. 110 p.

He, X.-h.; Scanlon, A.; Li, P. 2011. Dynamic factor of bridges subjected to linear induction motor train load, The Baltic Journal of Road and Bridge Engineering 6 (3): 185192. doi:10.3846/bjrbe.2011.24.

Ho, C.; Hyslip, J. P.; Li, D. 2009. Spectral analysis of ground acceleration-based testing, Transportation Research Record 2117: 50-56. 
Huang, H.; Shen, S.; Tutumluer, E. 2009a. Sandwich model to evaluate railroad asphalt trackbed performance under moving loads, Transportation Research Record 2117: 5765. doi:10.3141/2117-08.

Huang, H.; Tutumluer, E.; Dombrow, W. 2009b. Laboratory characterization of fouled railroad ballast behavior, Transportation Research Record 2117: 93-101. doi:10.3141/2117-12.

Jabri, S.; El Koursi, E. M.; Bourdeaud'huy, T.; Lemaire, E. 2010. European railway traffic management system validation using UML/Petri nets modelling, European Transport Research Review 2(2): 113-128.

Jakimavičius, M.; Burinskienè, M. 2007. Automobile transport system analysis and ranking in Lithuanian administrative regions, Transport 22(3): 214-220.

Jonaitis, J. 2006. Determination of extreme train running parameters along a railway line segment, Transport 21(2): 123-130.

Jonaitis, J. 2007. Planning of the amount of trains needed for transportation by rail, Transport 22(2): 83-89.

Juršènas, V.; Vaičiūnas, G. 2007. A survey of methods used for assessing the performance of diesel locomotives, Transport 22(1): 28-30.

Kendall, M. 1970. Rank Correlation Methods. $4^{\text {th }}$ ed. London: Griffin and Co. 365 p.

Keršys, R.; Bazaras, Ž. 2001. Keleivinio vagono dinamika važiuojant izoliuotomis įdubomis, Transportas 16 (3): 93-99.

Koutsopoulos, H. N.; Wang, Z. 2006. Simulation of urban rail operations, Transportation Research Record 2006: 84-91. doi: 10.3141/2006-10.

Koc, W. Ph. D., D. Sc. 2012. Design of rail-track geometric systems by satellite measurement, Journal of Transportation Engineering Vol. 138, No. 1: 114-122. doi:10.1061/(ASCE)TE.1943-5436. 0000303.

Kuo, A.; Miller-Hooks, E.; Zhang, K.; Mahmssani, H. 2008. Train slot cooperation in multicarrier, international rail-based intermodal freight transport, Transportation Research Record 2043: 31-40. doi:10.3141/2043-04.

Lai, Y.-T.; Wang, W.-C.; Wang, H.-H. 2008. AHP - and simulation-based budget determination procedure for public building construction projects, Automation in Construction 17(5): 623-632.

Lai, Y.-Ch. [R].; Barkan, Ch. P. L. 2009. Enhanced parametric railway capacity evaluation tool, Transportation Research Record 2117: 33-40. doi:10.3141/2117-05.

Lashgari, A.; Fouladgar, M. M.; Yazdani-Chamzini, A.; Skibniewski, M. J. 2011. Using anintegrated model for shaft sinking method selection, Journal of Civil Engineering and Management 17(4): 569-580. doi:10.3846/13923730.2011.628687.

Lata, M. 2008. The modern wheelset drive system and possibilities of modelling the torsion dynamics, Transport 23(2): 172-181. 
Lei, X.; Zhang, B. 2011. Analysis of dynamic behavior for slab track of high-speed railway based on vehicle and track elements, Journal of Transportation Engineering 137 (4): 227-240. doi: 10.1061/(ASCE)TE.1943-5436.0000207.

Li, D.; Bilow, D. N. 2008. Testing of slab track under heavy axle loads, Transportation Research Record 2043: 55-64. doi:10.3141/2043-07.

Lietuvos geležinkeliai. Metinè ataskaita 2010. Vilnius. 42 p.

Lietuvos geležinkeliai. Metinè ataskaita 2011. Vilnius. 39 p.

Lin, L.-k.; Chang, C.-c.; Lin, Y.-c. 2011. Structure development and performance evaluation of construction knowledge management system, Journal of Civil Engineering and Management 17(2): 184-196. doi:10.3846/13923730.2011.576833.

Lingaitienè, O.; Lingaitis, V. 2006. Use of an expenditure reducing model in railway carriage, Transport 21(1): 53-55.

Liu, W.; Xu, H.; Zhao, X. 2009. Agile service oriented shipping companies in the container terminal, Transport 24(2): 143-153. doi:10.3846/1648-4142.2009.24.143-153.

Liudvinavičius, L.; Lingaitis, L. P. 2007. Electrodynamic braking in high-speed rail transport, Transport 22(3): 178-186.

Lopez-Pita, A.; Teixeira, P. F.; Casas, C.; Bachiller, A.; Ferreira, P. A. 2008. Maintenance costs of high-speed lines in Europe. State of the art, Transportation Research Record 2043: 13-19. doi:10.3141/2043-02.

MacCrimmon, K. R. 1968. Decisionmaking Among Multiple - Attribute Alternatives: A Survey and Consolidated Approach, RAND Memorandum, RM-4823-ARPA.

MacCrimmon, K. R.; Wehrung, D. A. 1977. Trade - off Analysis: the indifference and preferred proportions approaches, w: Conflicting objectives in decisions. Bell D. E., Keeney R. L. and Raiffa H. (ed.), Wiley, New York, p. 123-147.

Mačiulis, A.; Vasilis Vasiliauskas, A.; Jakubauskas, G. 2009. The impact of transport on the competitiveness of national economy, Transport 24(2): 93-99. doi:10.3846/16484142.2009.24.93-99.

Magyla, T. 2002. The evaluation of implementation impact of centralized traffic control systems in railways, Transport 17(3): 96-102.

Martinelli, F.; Cara, S.; Domenichini, L. 2008. Rail tunnel risk analysis. A tool to improve rail tunnel design, Transportation Research Record 2043: 41-48. doi:10.3141/ 2043-05.

Maskeliūnaitè, L.; Sivilevičius, H.; Podvezko, V. 2009a. Research on the quality of passenger transportation by railway, Transport 24(2): 100-112. doi:10.3846/16484142.2009.24.100-112.

Maskeliūnaitė, L.; Sivilevičius, H. 2009b. Traukinius aptarnaujančio personalo nuomonès apie keleivių vežimo kokybès kriterijų svarbą nustatymas AHP metodu [Using AHP method for determining the significance of quality criteria of passenger transportation by 
train based on service people], Mokslas - Lietuvos ateitis [Science - future of Lithuania] 1(6): 57-62. doi:10.3846/mla.2009.6.12.

Maskeliunaite, L.; Sivilevicius, H. 2011. Applying AHP technique to the assessment of railway trip quality (RTQ), in The $8^{\text {th }}$ International Conference "Environment Engineering”: Selected papers, vol. 3. Ed. by D. Čygas, K. D. Froehner. May 19-20, 2011, Vilnius, Lithuania. Vilnius: Technika, 1193-1199.

Maskeliūnaitè, L.; Sivilevičius, H. 2012. Expert evaluation of criteria describing the quality of travelling by international passenger train: technological, economic and safety perspectives, Technological and Economic Development of Economy 18 (3): 544-566. doi: $10.3846 / 20294913.2012 .710178$.

Mišauskaitè, I.; Bagdonas, V. 2006. Algorithm for optimal correction of train traffic schedule, Transport 21(2): 112-118.

Montgomery, D. C. 2008. Introduction to Statistical Quality Control. 6 edition. Wiley. $734 \mathrm{p}$.

Morgan, C. A.; Olson, L. E.; Kyte, T. B. 2007. Development and pilot testing of crew resource management training program for railroad industry, Transportation Research Record 1995: 62-68. doi:10.3141/1995-08.

Morkvènas, R.; Bivainis, J.; Jaržemskis, A. 2008. Assessment of employee's knowledge potential in transport sector, Transport 23 (3): 258-265. doi:10.3846/16484142.2008.23.258-265.

Nakagawa, A.; Matsuda, S. 2005. Status of development and running tests on Japan's superconducting maglev, Transportation Research Record 1916: 26-29.

Nash, A.; Weidmann, U.; Buchmueller, S.; Rieder, M. 2007. Assessing feasibility of transport megaprojects. Swissmetro european market study, Transportation Research Record 1995: 35-42. doi:10.3141/1995-03.

Noorzaei, J.; Pour, P. M.; Jaafar, M. S.; Fong, Y. Ch.; Thanoon, W. A-M. 2012. Numerical simulation of railway track supporting system using finite-infinite and thin layer elements under impulsive loads, Journal of Civil Engineering and Management 18(2): 245-252. doi:10.3846/13923730.2012.671286.

Pan, N.-F. 2008. Fuzzy AHP approach for selecting the suitable bridge construction method, Automation in Construction 17(8): 958-965.

Paslawski, J. 2009. Flexibility in highway noise management, Transport 24(1): 66-75.

Peltier, D.; C.; Barkan, C. P. L. 2009. Characterizing and inspecting for progressive epoxy debonding in bonded insulated rail joints, Transportation Research Record 2117 : 85-92. doi:10.3141/2117-11.

Picoux, B.; Houédec, D. L. 2005. Diagnosis and prediction of vibration from railway trains, Soil Dynamics and Earthquake Engineering 25 (2005): 905-921. doi:10.1016/j.soildyn.2005.07.002. 
Podvezko, V. 2005. Ekspertu ịverčių suderinamumas, Ükio technologinis ir ekonominis vystymas 11 (2): 101-107.

Podvezko, V. 2009. Application of AHP technique, Journal of Business Economics and Management 10(2): 181-189. doi: 10.3846/1611-1699.2009.10.181-189.

Podvezko, V.; Mitkus, S.; Trinkūnienè, E. 2010. Complex evaluation of contracts for construction, Journal of Civil Engineering and Management 16(2): 287-297. doi:10.3846/jcem.2010.33.

Preston, J.; Wall, G.; Batley, R.; Ibáñez, J. N.; Shires, J. 2009. Impact of delays on passenger train services. Evidence from Great Britain, Transportation Research Record 2117: 14-23. doi: 10.3141/2117-03.

Ramunas, V.; Gailienè, I.; Podagèlis, I. 2011. Increment of railway line capacity, in The $8^{\text {th }}$ International Conference "Environment Engineering": Selected papers, vol. 3. Ed. by D. Čygas, K. D. Froehner. May 19-20, 2011, Vilnius, Lithuania. Vilnius: Technika, 1193-1199.

Rao, A.; Tsai, T. 2007. Safety standards for high-speed rail transportation, Transportation Research Record 1995: 1-8. doi:10.3141/1995-05.

Saaty, T. L. 1980a. The Analytic Hierarchy Process. McGraw-Hill, New York.

Saaty, T. L. 1980b. The Analytic Hierarchy Process: Planing, Priority Setting, Resource Allocation. McGraw-Hill International Book Co., New York.

Sakalauskas, K; Rezgaitis, R. 2000. Greituju keleiviniu traukiniu eismo problemos ir perspektyvos, Transportas 15(5): 244-256.

Sasaki, K. 2005. Position-detecting system based on the global positioning system. Potential use in improving car body tilt control, Transportation Research Record 1916: 3033.

Sauter-Servaes, T.; Nash, A. 2007. Applying low-cost airline pricing strategies to European railroads, Transportation Research Record 1995: 1-8. doi:10.3141/1995-01.

Sauter-Servaes, T.; Nash, A. 2009. Increasing rail demand by improving multimodal information and ticketing. Results of the night\&flight case study, Transportation Research Record 2117: 7-13. doi:10.3141/2117-02.

Savaeigio kelio matavimo vagono EM-140 matuojamu geležinkelio kelio geometriniu parametru ivvertinimo instrukcija (K/259) (patvirtinta AB „Lietuvos geležinkeliai“ generalinio direktoriaus $2012 \mathrm{~m}$. sausio 4 d. issakymu Nr. [-10). 2012. Vilnius: UAB „Geležinkelių produkcijos atitikties vertinimo centras“. $18 \mathrm{p}$.

Scalea, F. L.; Bartoli, I.; Rizzo, P.; Fateh, M. 2005. High-speed defect detection in rails by noncontact guided ultrasonic testing, Transportation Research Record 2005: 66-77.

Schach, R.; Naumann, R. 2007. Comparison of high-speed transportation systems in special consideration of investment costs, Transport 22(3): 139-147.

Schafer II, D. H.; Barkan, C. P. L. 2008. Relationship between train length and accident causes and rates, Transportation Research Record 2043: 73-82. doi:10.3141/2043-09. 
Schwieterman, J. P.; Scheidt, J. 2007. Survey of current high-speed rail planning efforts in the United States, Transportation Research Record 1995: 27-34. doi:10.3141/199504.

Sevi, A.; Ge, L. 2012. Cyclic behaviors of railroad ballast within the parallel gradation scaling framework, Journal of Materials in Civil Engineering 24(7): 797-804. doi:10.1061/(ASCE)MT.1943-55330000460.

Si, B.; Zhong, M.; Gao, Z. 2009. Bilevel programming for evaluating revenue strategy of railway passenger transport under multimodal market competition, Transportation Research Record 2117: 1-6. doi:10.3141/2117-01.

Simpson, D. P. 2007. Preserving freight and passengers rail corridors and service. A synthesis of highway practice. National cooperative highway research program (NCHRP). Synthesis 374. Transportation Research Board, National Research Council, Washington, D. C.: National Academy Press. 32 p. ISSN 0547-5570.

Sivilevičius, H. 2001. Asfaltbetonio maišytuvo kokybės kompleksinio vertinimo kriterijai ir metodika, Statyba, 7 (3): 213-223.

Sivilevičius, H. 2002. Asfaltbetonio maišytuvo kokybės kompleksinio vertinimo kriterijų pagrindimas ir metodikos taikymas praktikoje, Journal of Civil Engineering and Management, 8 (2): 112-125.

Sivilevičius, H.; Zavadskas, E. K.; Turskis, Z. 2008. Quality attributes and complex assessment methodology of the asphalt mixing plant, The Baltic Journal of Road and Bridge Engineering 3(3): 161 - 166. doi:10.3846/1822-427X.2008.3.161-166.

Sivilevičius, H.; Maskeliūnaite, L. 2010. The criteria for identifying the quality of passengers' transportation by railway and their ranking using AHP method, Transport 25(4): 368-381. doi:10.3846/transport.2010.46.

Sivilevičius, H. 2011a. Modelling the interaction of transport system elements, Transport 26 (1): 20-34. doi:10.3846/16484142.2011.560366.

Sivilevičius, H. 2011b. Application of expert evaluation method to determine the importance of operating asphalt neixing plant quality criteria and rank correlation, The Baltic Journal of Road and Bridge Engineering 6 (1): 48-58. doi:10.3846/bjrbe.2011.07.

Sivilevičius, H.; Maskeliūnaitè, L.; Petkevičienè, B.; Petkevičius, K. 2012. The model of evaluating the criteria, describing the quality of organization and technology of travel by international train, Transport 27(3): 307-319. doi:10.3846/16484142.2012.724448.

Skibniewski, M. J.; Chao, L.-C. 1992. Evaluation of advanced construction technology with AHP method. Journal of Construction Engineering and Management 118(3): 577593.

Sonmez, R.; Ontepeli, B. 2009. Predesign cost estimation of urban railway projects with parametric modelling, Journal of Civil Engineering and Management 15(4): 405-409. doi: 10. 3846/1392-3730.2009.15.405-409. 
Stenbeck, T. 2008. Quantifying effects of incentives in a rail maintenance performancebased contract, Journal of Construction Engineering and Management 134(4): 265-272. doi:10.1061/(ASCE)0733-9364(2008)134:4(265).

Strang, J.; Hynes, R.; Peacock, T.; Lydon, B.; Woodbury, C.; Stastny, J.; Tyrell, D. 2007. Development of crash energy management specification for passenger rail equipment, Transportation Research Record 2006: 76-83. doi:10.3141/2006-09.

Stribersky, A.; Moser, F.; Rulka, W. 2000. Structural dynamics of rail vehicle systems: a virtual systems approach, Developments in Engineering Computational technology: 2936.

Suh, S. D.; Yang, K.-Y. 2005. Customers' reactions to the introduction of high-speed rail service. Korean train express, Transportation Research Record 1916: 20-25.

Tamošaitienė, J. 2009. Daugiatikslis valdymo sprendimu vertinimas statybos planavimo etape [The multi-attribute assessment of management decisions at the stage of construction planning]: daktaro disertacija. Technologijos mokslai, statybos inžinerija (02T). Vilnius: Technika. 149 p. ISBN 978-9955-28-433-8.

Tanczos, K.; Torok, A. 2007. The linkage between climate change and energy consumption of hungary in the road transportation sector, Transport 22(2): 134-138.

Tica, S.; Radojičic, V.; Markovič, G.; Markovič, D. 2011. Modeling for evaluations of call center for public traffic and transport systems, Technological and Economic Development of Economy 17(1): 116-132. doi:10.3846/13928619.2011.554023.

Tupènaite, L.; Zavadskas, E. K.; Kaklauskas, A.; Turskis, Z.; Seniut, M. 2010. Multiple criteria assessment alternatives for built and human environment renovation, Journal of Civil Engineering and Management 16(2): 257-266. doi:10.3846/jcem.2010.30.

Turskis, Z.; Zavadskas, E. K. 2010. A new fuzzy additive ratio assessment method (ARAS-F). Case study: the analysis of fuzzy multiple criteria in order to select the logistic centers location, Transport 25(4): 423-432.

Ustinovichius, L.; Zavadskas, E. K.; Podvezko, V. 2007. Application of a quantitative multiple criteria decision making (MCDM-1) approach to the analysis of investments in construction, Control and Cybernetics 36(1): 251-268.

Vaičiūnas, G.; Lingaitis, L. P. 2008. Investigating the dynamics of passenger rolling stock deterioration, Transport 23(1): 51-54.

Vainiunas, P.; Zavadskas, E. K.; Peldschus, F.; Turskis, Z.; Tamosaitiene, J. 2009. Model of construction design projects' managers qualifying by applying Analytic Hierarchy Process and Bayes rule. In Proc. Of the 5th International Vilnius Conference EURO Mini Conference "Knowledge-Based Technologies and OR Methodologies for Strategic Decisions of Sustainable Development": Selected papers. Ed. by M. Grasserbauer, L. Sakalauskas, E. K. Zavadskas. September 30-October 3, 2009, Vilnius, Lithuania. Vilnius: Technika. 154-158. 
Vale, C.; Ribeiro, I. M.; Calcada, R. 2012. Integer programming to optimize tamping in railway tracks as preventive maintenance, Journal of Transportation Engineering Vol. 138, No.1: 123-131. doi: 10.1061/(ASCE)TE. 1943-5436.0000296.

Vilčeková, S.; Krídlová Burdová, E.; Ondová, M. 2011. Site selection and project planning resulting in sustainable buildings, in The $8^{\text {th }}$ International Conference "Environment Engineering”: Selected papers, vol. 3. Ed. by D. Čygas, K. D. Froehner. May 1920, 2011, Vilnius, Lithuania. Vilnius: Technika, 1009-1013.

Walker, W. E.; Baarse, G.; van Velzen, A.; Järvi, T. 2008. Assessing barriers to improving rail interoperability in European countries, Transportation Research Record 2043: 20-30. doi:10.3141/2043-03.

Wang. K. C. P.; Li, Q.; Hall, K. D.; Elliott, R. P. 2007. Experimentation with Gray theory for pavement smoothness prediction, Transportation Research Record 1990: 3-13. doi:10.3141/1990-01.

Weed, R. M.; Schmitt, R. L.; Owusu-Ababio, S. 2007. Ranking procedure based on statisticalhypothesis testing, Transportation Research Record 1991: 12-18.

White, T. 2005. Alternatives for railroad traffic simulation analysis, Transportation Research Record 1916: 34-41.

With, Ch.; Bahrekazemi, M.; Bodare, A. 2006. Validation of an empirical model for prediction of train-induced ground vibrations, Soil Dynamics and Earthquake Engineering 26 (2006): 983-990. doi:10.1016/j.soildyn.2006.03.005.

Wu, Z.; Flintsch, G. W.; Chowdhury, T. 2008. Hybrid multiobjective optimization model for regional pavement-preservation resource allocation, Transportation Research Record 2084: 28-37.

Xia, H.; Guo, W. W.; Zhang, N.; Sun, G. J. 2008. Dynamic analysis of a train-bridge system under wind action, Computers and Structures 86 (2008) 1845-1855. doi:10.1016/j.compstruc. 2008.04.007.

Zavadskas, E. K.; Kaklauskas, A.; Banaitienè, N. 2001. Pastato gyvavimo proceso daugiakriterine analizé. Vilnius: Technika. 379 p. ISBN 9986-05-441-9.

Zavadskas, E. K.; Šaparauskas, J.; Kazlauskas, A.; Turskis, Z.; Vilutienė, T. 2005. Vilniaus darnos vertinimas socialiniu, ekonominiu, inžineriniu bei techniniu aspektais taikant lošimų teoriją [Evaluation of Vilnius sustainability from social, economic and engineering-technical points of view using the game theory], Technological and Economic Development of Economy 11(2): 134-143.

Zavadskas, E. K.; Turskis, Z.; Tamošaitienè, J. 2010. Risk assessment of construction project, Journal of Civil Engineering and Management 16(1): 33-46. doi:10.3846/13923730.2010.16.33-46.

Zhao, J.; Chan, A. H. C.; Burrow, M. P. N. 2007. Probabilistic model for predicting rail breaks and controlling risk of derailment, Transportation Research Record 1995: 76-83. doi:10.3141/1995-10. 
Zhu, Z-y.; Ling, X-z.; Chen, S-j.; Zhang, F.; Wang, Z-y. 2011. Analysis of dynamic compressive stress induced by passing trains in permafrost subgrade along QinghaiTibet railway, Cold Regions Science and Technology 65 (2011) 465-473. doi:10.1016/j.coldregions. 2010.10.011.

Zhuo, W.; Li-min, I. 2011. The theory and method of design and optimization for railway Intelligent Transportation Systems (RITS). 149 p. eISBN: 978-1-60805-138-0.

Ziari, H.; Keymanesh, M. R.; Khabirl, M. M. 2007. Locating stations of public transportation vehicles for improving transit accessibility, Transport 22(2): 99-104.

Žvirblis, A.; Zinkevičiūte, V. 2008. The integrated evaluation of the macro environment of companies providing transport services, Transport 23(3): 266-272.

Айвазян, С. А.; Мхитарян, В. С. 2001. Теория вероятностей и прикладная статистика [Aivazian, S. A.; Mkhitarian, V. S. 2001. Probability Theory and Applied Statistics]. Москва: Юнити. 656 с.

Белов, И. В.; Терешина, Н. П. Галабурда, В. Г. и др. 2001. Экономика железнодорожного транспорта [Belov, I. V.; Terešina, N. P.; Galaburda, V. G. Geležinkelių transporto ekonomika]. Москва: Маршрут. 600 с. ISBN 5-89035-056-0.

Воробъев, А. А.; Иванов, И. А.; Кононов, Д. П.; Тарапанов, А. С. 2011. Анализ методов восстановления профиля катания колесных пар, Вестник ВНИИЖТ 3: 3438.

Горбунов, М. А. 2010. Определение непрерывного распределения средних значегий нормалъных напряжений в релъсах под проходящим экипажем в прямых и кривых участках пути, Вестник ВНИИЖТ 5: 29-32.

Евланов, Л. Г. 1984. Теория и практика принятия решений [Evlanov, L. Sprendimų priemimo teorija ir praktika]. Москва: Экономика. $176 \mathrm{c.}$

Елисеев, И. А. 2010. Стохастическая моделъ силы тяги локомотива, Вестник ВНИИЖТ 4: 30-33.

Жаров, И. А. 2010. Выбор показателей критериев и неровностей пути при оценке вероятности схода экипажа, Вестник ВНИИЖТ 6: 20-23.

Завадскас, Э. К. 1987. Комплексная оценка и выбор ресурсосберегающих решений в строительстве. Вильнюс: Мокслас. 212 с.

Захаров, С. М.; Ромен, Ю. С. 2010а. Математическое моделирование влияния параметров пути и подвижного состава на процессы изнашивания колеса и релъса, Вестник ВНИИЖТ 2: 26-30.

Захаров, С. М.; Погорелов, Д. Ю.; Симонов, В. А. 2010b. Анализ влияния параметров экипажей и пути на интенсивностъ износа в системе колесо - релъс (на основе полного факторного численного эксперимента), Вестник ВНИИЖТ 2: 31-35.

Ивницкий, В. А.; Полякова, М. А. 2011. О коэффициенте надежности железнодорожного участка, Вестник ВНИИЖТ 5: 14-18. 
Кендэл, М. 1975. Ранговые корреляции. Москва: Статистика. 216 с.

Кремер, Н. Ш. 2003. Теория вероятностей и математическая статистика [Kremer, N. Š. Tikimybių teorija ir matematinè statistika]. Москва: ЮНИТИ. 573 с.

Лапидус, Б. М.; Мачерет, Д. А. 2011. Эволюция железнодорожного транспорта на пути к инновационному ренессансу, Вестник ВНИИЖТ 1: 3-14.

Лысюк, В. С.; Сазонов, В. Н.; Башкатова, Л. В. 2003. Прочный и надежный железнодорожный путь [Lysiuk, V. S.; Sazonov, V. N.; Baškatova, L. V. Tvirtas ir patikimas geležinkelis]. Москва: ИКЦ „Академкнига“. 589 с. ISBN 5-94628-112-7.

Макарова, Е. А.; Елизаров, С. Б.; Муктепавел, С. В. 2011. Автоматизированная система прогнозирования пассажирских транспортных потоков на базе АСУ «Экспресс», Вестник ВНИИЖТ 4: 21-27.

Мальцев, Ю. А.; Захаренков, И. Н. 2007. Учёт рисков в дорожном строительстве [Maltzev, Y. A.; Zakharenkov, I. N. Taking into account the risks in road construction], Наука и техника в дорожной отрасли [The Science and Engineering in a Road Sphere] 40(1): 6-9.

Марков, Д. П. 2011. Испытания рельсовых смазочных материалов на Экспериментальном кольце ОАО «ВНИИЖТ», Вестник ВНИИЖТ 2: 13-16.

Маскелюнайте Л.; Сивилявичюс, Г. 2008. Способы оценки и повышения качества пассажирских перевозок на железнодорожном транспорте [Maskeliūnaitė, L.; Sivilevičius, H. Keleivių vežimo geležinkeliais kokybès vertinimo ir gerinimo būdai], Проблемы автомобильно-дорожного комплекса России часть 1: материаль $V$ международной научно-технической конференции, 21-23 мая 2008 г. Пенза. Пенза: ПГУАС, с. 271-280. ISBN 978-5-9282-0465-5.

Маскелюнайте Л.; Сивилявичюс, Г. 2009c. Оценка пассажирами железнодорожного транспорта критериев качества их перевозок, Вестник УлГТУ 2(46): 67-71.

Мачерет, Д. А.; Рышков, А. В.; Белоглазов, А. Ю.; Захаров, К. В. 2010. Макроэкономическая оценка развития транспортной инфраструктуры, Вестник ВНИИЖТ 5: 3-10.

Мирошниченко, О. Ф.; Пастухов, С. С. 2006. Маркетинговое обследование скоростного полигона движения пассажирских поездов с местами для сидения (методология и результаты), Вестник ВНИИЖТ 3: 23-27.

Мирошниченко, О. Ф.; Огинская, А. Е.; Морозова, М. В. 2008. Методические подходы к выделению затрат ОАО «РЖД» по предоставлению услуг инфраструктуры иным перевозчикам, Вестник ВНИИЖТ 1: 28-30.

Мирошниченко, О. Ф.; Венедиктов, Г. Л.; Кочетков, В. М.; Пастухов, С. С. 2010. Методы реализации системы управления доходностъю применителъно к пассажирскому железнодорожному сообщению, Вестник ВНИИЖТ 6: 10-15. 
Огинская, А. Е.; Толкачева, Е. В. 2006. Методические подходы к определению уровня конкурентоспособности пригородных пассажирских перевозок, Вестник ВНИИЖТ 1: 44-47.

Пастухов, С. С. 2008а. Определение приоритетов пассажиров при оценке качества и выявление наиболее эффективных направлений улучшения качества транспортной услуги и сервиса в фирменных поездах (методология и результаты), Вестник ВНИИЖТ 1: 23-27.

Пастухов, С. С. 2008b. Определение основных путей повышения эффективности работы вагонов-ресторанов на основе маркетингового анализа, Вестник ВНИИЖТ 2: $42-47$.

Саати, Т. 1993. Принятие решений. Метод анализа иерархий [Saaty, T. Sprendimų prièmimas. Analizès hierarchijos metodas]. Москва: Радио и связь. 320 с.

Толкачева, М. М.; Мирошниченко, О. Ф. 2007. Предложения по совершенствованию тарифов для программы повышения эффективности пригородных пассажирских перевозок ОАО «РЖД», Вестник ВНИИЖТ 6: 3-7.

Финиченко, А. Ю. 2011. Нормирование расхода тепловой энергии в прачечных, дезинфекционных камерах и на химчистку рабочей одежды в стационарном производстве на железнодорожном транспорте, Вестник ВНИИЖТ 2: 38-41.

Черкашин, Ю. М.; Погорелов, Д. Ю. 2010. Влияние параметров экипажей и пути на безопасностъ движения поездов, Вестник ВНИИЖТ 2: 3-9.

Шикин, Е. В.; Чхартишвили А. Г. 2000. Математические методы и модели в управлении [Šikin, E. V.; Čhartišvili, A. G. Matematiniai valdymo metodai ir modeliai]. Москва: Дело. 440 с.

Шубин, И. В. 2006. Проблемы развития вспомогательного бизнеса пассажирского комплекса дальнего следования, Вестник ВНИИЖТ 2: 34-37.

Щеглов, П. П.; Жолобов, В. И.; Алексанянц, С. К.; Ромашкин, Х. М.; Гаврилова, Т. А. 2007. К вопросу эвакуации пассажиров из вагонов электропоезда и вагонов поездов дальнего следования при возникновении пожара, Вестник ВНИИЖТ 2: $27-30$. 


\section{Autorès publikaciju disertacijos tema sąrašas}

\section{Straipsniai recenzuojamuose mokslo žurnaluose}

Maskeliūnaite, L.; Sivilevičius, H.; Podvezko, V. 2009. Research on the quality of passenger transportation by railway, Transport 24(2): 100-112. ISSN 1648-4142. doi: 10.3846/1648-4142.2009.24.100-112 (IF=2,552; AIF =0,884). (Thomson Reuters ISI Web of Science)

Maskeliūnaite, L.; Sivilevičius, H. 2012. Expert evaluation of criteria describing the quality of travelling by international passenger train: technological, economic and safety perspectives, Technological and Economic Development of Economy 18(3): 544-566. ISSN 2029-4913. doi:10.3846/20294913.2012.710178 ( IF = 3,235) (2011). (Thomson Reuters ISI Web of Science)

Sivilevičius, H.; Maskeliūnaite, L. 2010. The criteria for identifying the quality of passengers' transportation by railway and their ranking using AHP method, Transport 25(4): 368-381. ISSN 1648-4142. doi:10.3846/transport.2010.46 (IF nesuteikè). (Thomson Reuters ISI Web of Science)

Sivilevičius, H.; Maskeliūnaitè, L.; Petkevičienè, B.; Petkevičius, K. 2012. The model of evaluating the criteria, describing the quality of organization and technology of travel by international train, Transport 27(3): 307-319. ISSN 1648-4142. doi: 10.3846/16484142. 2012.724448. (Thomson Reuters ISI Web of Science) 
Maskeliūnaitè, L.; Sivilevičius, H. 2009. Traukinius aptarnaujančio personalo nuomonès apie keleivių vežimo kokybės kriterijų svarbą nustatymas AHP metodu, Mokslas - Lietuvos ateitis [Science - Future of Lithuania] 1(16). Vilnius: Technika, 22-28. ISSN 2029-2341. doi:10.3846/mla.2009.6.12. (IndexCopernicus)

Маскелюнайте Л.; Сивилявичюс, Г. 2009. Оценка пассажирами железнодорожного транспорта критериев качества их перевозок, в кн. Вестник УлГТУ 2: 67-71. ISSN 1674-7016.

\section{Straipsniai kituose leidiniuose}

Маскелюнайте, Л.; Сивилявичюс, Г. 2008. Способы оценки и повышения качества пассажирских перевозок на железнодорожном транспорте // Проблемы автомобилъно-дорожного комплекса России: материалы V международной научнотехнической конференции 21-23 мая 2008 года, Пенза / Пензенский государственный университет архитектуры и строителъства. Часть 1. Пенза: ПГУАС, 2008. ISBN 9785928204655. c. 271-280.

Maskeliunaite, L.; Sivilevicius, H. 2011. Applying AHP technique to the assessment of railway trip quality (RTQ), in The $8^{\text {th }}$ International Conference "Environment Engineering”: Selected papers, vol. 3. Ed. by D. Čygas, K. D. Froehner. May 19-20, 2011, Vilnius, Lithuania. Vilnius: Technika, 1193-1199. ISSN 2029-7106.

Maskeliūnaitė, L.; Sivilevičius, H. 2008. Keleivių vežimo geležinkeliais gerinimo būdai//10-osios Lietuvos jaunujų mokslininkų konferencijos „Mokslas - Lietuvos ateitis“ 2007 metų teminès konferencijos TRANSPORTAS (2007 m. gegužès 3 d.) straipsnių rinkinys / Vilniaus Gedimino technikos universitetas. Vilnius: Technika, 2008. ISBN 9789955283744. p. 423-433. 


\section{Priedai $^{*}$}

A priedas. Kriterijų, susietų su kelionės traukiniu proceso organizavimu ir technologija, kiekybinio ivertinimo (balo) 1-ojo respondento nustatymo anketa

B priedas. A, B, C ir D grupių kriterijų svarbos nustatymas ir rangavimas pagal keleivių nuomonę

$\mathrm{C}$ priedas. A, B, C ir D grupių kriterijų svarbos nustatymas ir rangavimas pagal traukinį aptarnaujančio personalo nuomonę

D priedas. A, B, C ir D grupių kriterijų svarbos nustatymas ir rangavimas pagal administracijos darbuotojų nuomonę

E priedas. Kelionės traukiniu kokybės A, B, C ir D kriterijų grupių svarbos (pirmumo) nustatymo anketa (su 1-ojo respondento suteiktais rangais)

F priedas. Kelionès traukiniu kokybès kriterijų $\mathrm{A}, \mathrm{B}, \mathrm{C}$ ir $\mathrm{D}$ grupių pirmumo ivertinimas $R_{i j}$ (rangai) respondentų ir ekspertų požiūriu

G priedas. Svarbiausių Lietuvos Respublikos geležinkelio kelių KKI, išmatuoto kelmačiu EM-140 (kas kilometras), 2012 m. vasario-gegužès mènesiais, kitimas ir jo atitiktis normų reikalavimams

${ }^{*}$ Priedai pateikiami pridètoje kompaktinèje plokštelèje. 
H priedas. Kelmačiu EM-140 2012 m. išmatuotų kelių kokybės indekso (KKI) reikšmių pasiskirstymas (dinamika)

I priedas. Kelmačiu EM-140 2012 m. išmatuotų kelių kokybės indekso (KKI) reikšmių procentinis pasiskirstymas (dinamika)

J priedas. Kelio Vilnius-Kena (I pagrindinio) 2012 m. sausio mèn. išmatuoti geometriniai kelio parametrai

K priedas. Traukinio Vilnius-Maskva tvarkaraštis

L priedas. Rodiklio $K$ skaičiavimas 
Lijana MASKELIŪNAITÉ

TARPTAUTINIO KELEIVIỤ VEŽIMO GELEŽINKELIAIS PROCESO KOKYBĖS TYRIMO DAUGIATIKSLIS MODELIS

Daktaro disertacija

Technologijos mokslai,

transporto inžinerija (03T)

THE MODEL FOR MULTICRITERIA EVALUATION OF THE QUALITY OF

PASSENGER TRANSPORTATION BY INTERNATIONAL TRAINS

Doctoral Dissertation

Technological Sciences,

Transport Engineering (03T)

Redaktorè Angelika Petrètiené

$20121207.15,75$ sp. I. Tiražas 20 egz.

Vilniaus Gedimino technikos universiteto

leidykla „Technika“,

Saulètekio al. 11, 10223 Vilnius,

http://leidykla.vgtu.It

Spausdino UAB "Ciklonas"

J. Jasinskio g. 15, 01111 Vilnius 
